Florida International University FIU Digital Commons

$3-7-2014$

\title{
A Visual Critical Ethnography Of Youth Development In A Rio de Janeiro Favela
}

Bryn E. Hafemeister Ed.D.

Florida International University, brynhafemeister@gmail.com

DOI: $10.25148 /$ etd.FI14040841

Follow this and additional works at: https://digitalcommons.fiu.edu/etd

Part of the Curriculum and Instruction Commons

\section{Recommended Citation}

Hafemeister, Bryn E. Ed.D., "A Visual Critical Ethnography Of Youth Development In A Rio de Janeiro Favela" (2014). FIU Electronic Theses and Dissertations. 1244.

https://digitalcommons.fiu.edu/etd/1244

This work is brought to you for free and open access by the University Graduate School at FIU Digital Commons. It has been accepted for inclusion in FIU Electronic Theses and Dissertations by an authorized administrator of FIU Digital Commons. For more information, please contact dcc@fiu.edu. 


\section{FLORIDA INTERNATIONAL UNIVERSITY \\ Miami, Florida}

\section{A VISUAL CRITICAL ETHNOGRAPHY OF YOUTH DEVELOMENT \\ IN A RIO DE JANEIRO FAVELA}

A dissertation submitted in partial fulfillment of

the requirements for the degree of

DOCTOR OF EDUCATION

in

CURRICULUM AND INSTRUCTION

by

Bryn E. Hafemeister 
To: Dean Delia C. Garcia

College of Education

This dissertation, written by Bryn E. Hafemeister, and entitled A Visual Critical

Ethnography of Youth Development in a Rio de Janeiro Favela, having been approved in respect to style and intellectual content, is referred to you for judgment.

We have read this dissertation and recommend that it be approved.

Bianca Freire-Medeiros

$\begin{array}{r}\hline \text { Maria K. Lovett } \\ \hline \text { Sarah A. Mathews } \\ \hline \text { Tonette S. Rocco } \\ \hline \text { Hilary Landorf, Major Professor }\end{array}$

Date of Defense: March 7, 2014

This dissertation of Bryn E. Hafemeister is approved.

Dean Delia C. Garcia
College of Education

Dean Lakshmi N. Reddi

University Graduate School

Florida International University, 2014 
(C) Copyright 2014 by Bryn E. Hafemeister

All rights reserved. 


\section{DEDICATION}

I dedicate this dissertation to my family.

Thank you for the enduring love, support, and guidance. 


\section{ACKNOWLEDGMENTS}

I extend my utmost gratitude to my dissertation committee members. Dr. Hilary Landorf, my major professor, encouraged me to pursue doctoral work and was so supportive as I explored possible avenues for this dissertation to take. My interest in using film and photography as a research tool was first born through the coursework that I completed with Dr. Maria Lovett. Dr. Tonette Rocco gave me invaluable advice for the organization and structure of the methodology, and encouraged me to persevere during difficult times. I deeply value Dr. Sarah Mathews' guidance in my chosen form of analysis. Dr. Bianca Freire-Medeiros was a huge support during my fieldwork in Rio de Janeiro. Her in-depth knowledge of the context of my study is much appreciated.

I am also grateful for the professors who gave me their input on this dissertation when it was still in its beginning stages. Dr. Linda Spears-Bunton gave valuable input on the structure of my literature review. Dr. Linda Bliss taught me so much about qualitative research, and encouraged me to turn what was originally a class project into something much larger. Drs. Linda Bliss and Isadore Newman conducted a valuable dissertation workshop that I attended for two semesters. This experience was extremely helpful as I learned how to write a dissertation.

My parents, Linda and Bruce Hafemeister, have been among my biggest fans and supporters. They embraced my love of other cultures as something that I hold deeply. They celebrated my accomplishments in this dissertation process and commiserated with me during the defeats. Thank you to the Morrinho group for sharing their project with me. And thank you to my friends in Pereira da Silva for welcoming me into their community. Obrigada mesmo. Without you all, none of this would have been possible. 


\title{
ABSTRACT OF THE DISSERTATION \\ A VISUAL CRITICAL ETHNOGRAPHY OF YOUTH DEVELOPMENT IN A RIO DE JANEIRO FAVELA
}

\author{
by \\ Bryn E. Hafemeister \\ Florida International University, 2014 \\ Miami, Florida \\ Professor Hilary Landorf, Major Professor
}

Favelas are Brazilian informal housing settlements that are areas of concentrated poverty. In Rio de Janeiro, favelas are perceived as areas of heightened criminal activity and violence, and residents experience discrimination, and little access to quality education and employment opportunities. In this context, hundreds of non-formal educational arts and leisure programs work to build the self-esteem and identity of youth in Rio's favelas as a way of preventing the youth from negative local influences.

The Morrinho organization, located in the Pereira da Silva favela in Rio, uses art as a way for the local male youth to communicate their lived reality. This study used a visual critical ethnographic methodology to describe the way in which the Morrinho participants interpret living in a favela. Seventeen semi-structured interviews with young men aged 15 to 29 , the feature-length documentary film on the organization, 206 researcher produced documentary style photographs of the Morrinho artwork, and the researcher's field notes were analyzed. Truth claims, ways of seeing as communicated through words and actions, were induced through a cyclical process of reconstructive horizon analysis that incorporated the societal context and critical theory. 
The participants communicated their concerns about life in a favela; however, they did not describe their societal positions in terms of complete marginalization. They named multiple benefits of living in Pereira da Silva, discussed positive and negative experiences in school, and described ways they circumvented discrimination. Morrinho as an organization was described as an enthralling game and a social project that benefited dozens of local youth. Character development was a valuable result of participation at Morrinho. The Morrinho artwork communicates a nuanced vision of both benevolent and violent social actors, and counters the overwhelmingly negative dominant characterization of Rio de Janeiro's favelas.

This study has implications for an inclusive critical pedagogy and the use of art as a means to facilitate a transformative education. Further research is recommended to explore terminology used to refer to favelas, and perceptions that favela residents have of their experiences in public education. 


\section{TABLE OF CONTENTS}

CHAPTER

PAGE

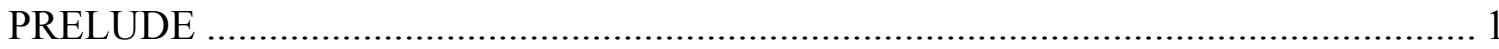

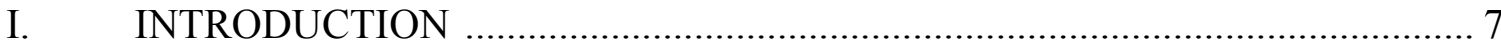

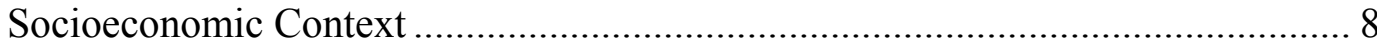

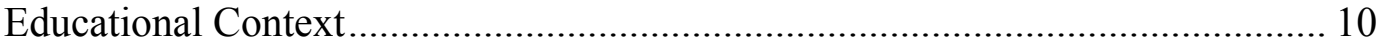

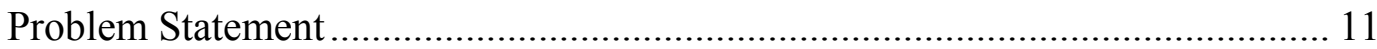

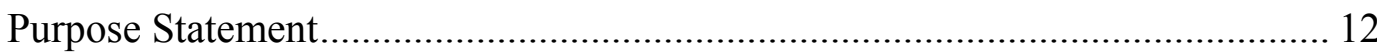

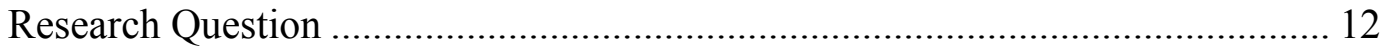

Conceptual Framework .................................................................................. 12

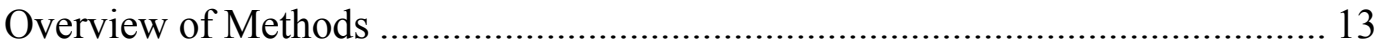

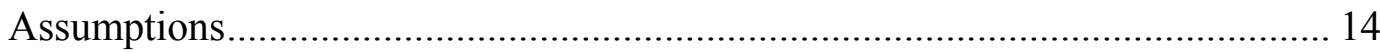

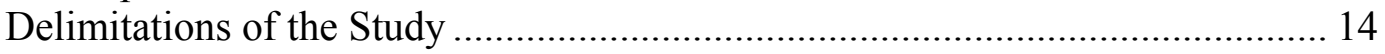

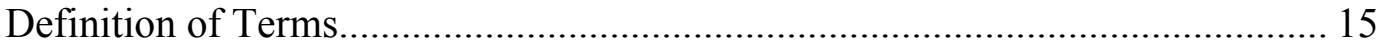

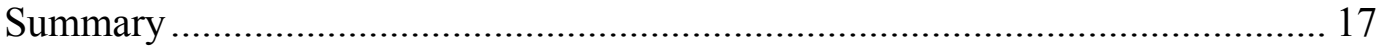

II. REVIEW OF THE RELATED LITERATURE _............................................ 19

Conceptual Framework ................................................................................ 19

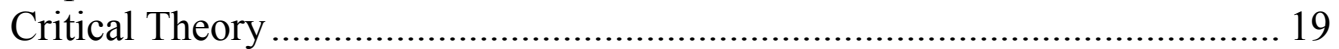

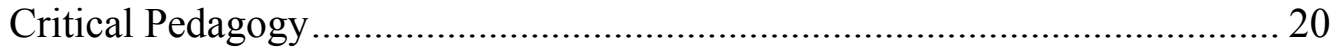

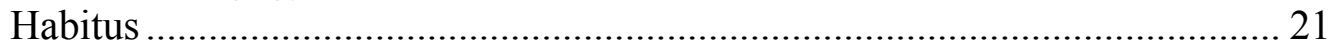

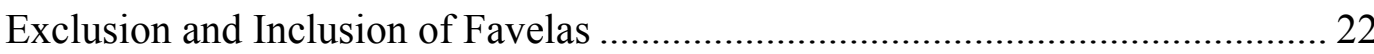

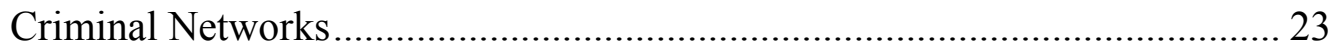

Police in Rio de Janeiro ………………..................................................... 24

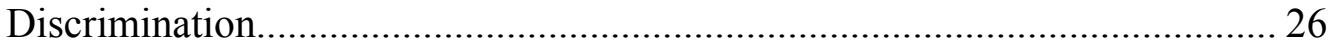

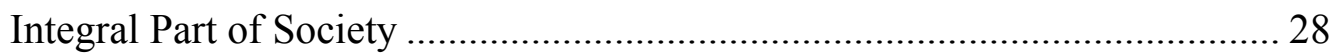

Demonstrations of Culture in Favelas................................................................. 30

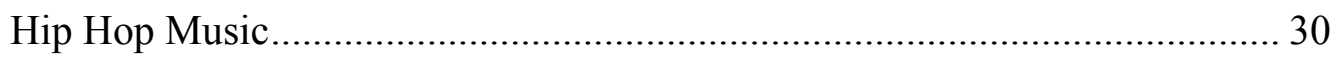

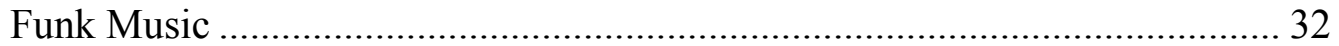

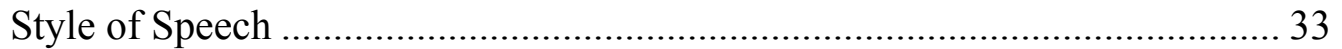

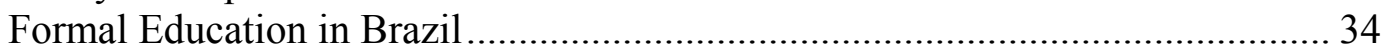

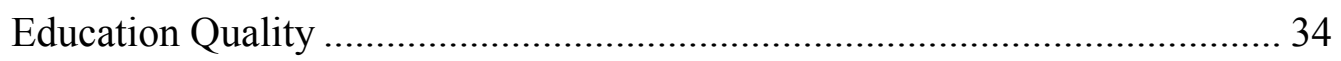

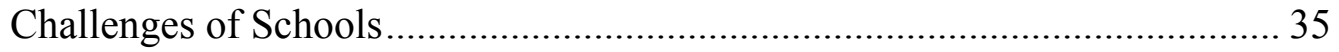

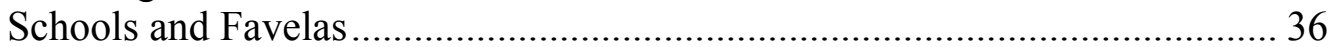

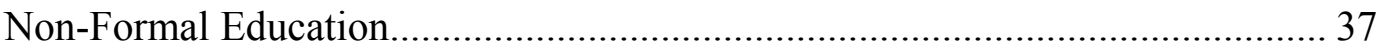

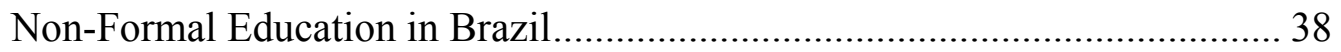

Case Studies of Non-Formal Education in Brazil............................................ 40

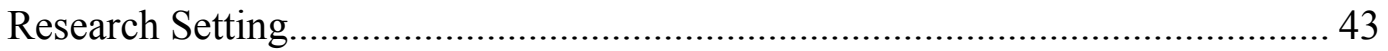

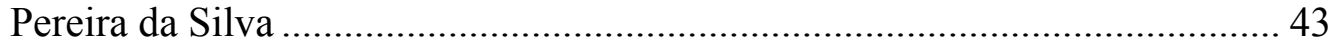

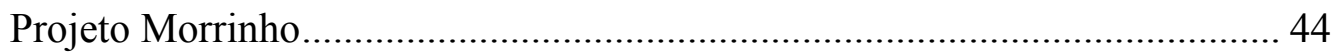

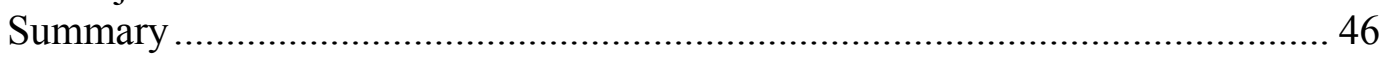




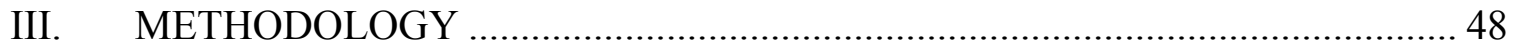

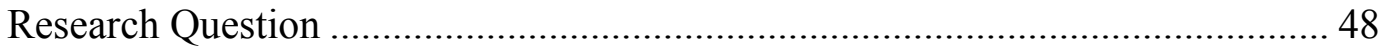

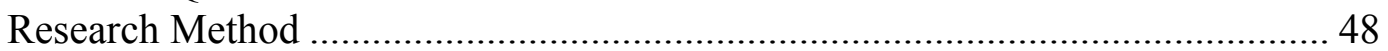

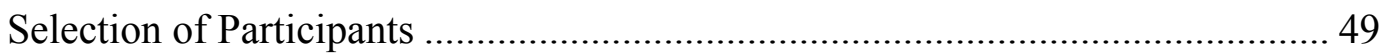

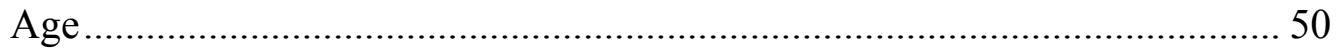

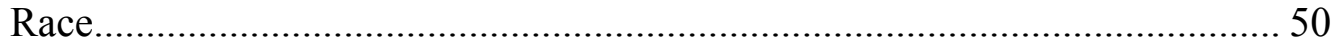

Time Lived in Pereira da Silva ................................................................. 51

Time Participated with Morrinho................................................................... 51

Education Level Completed......................................................................... 51

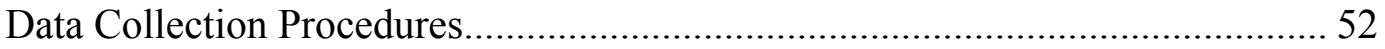

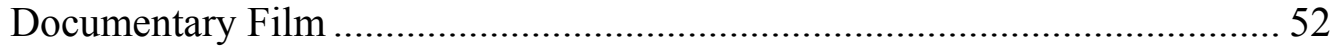

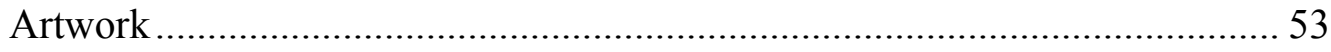

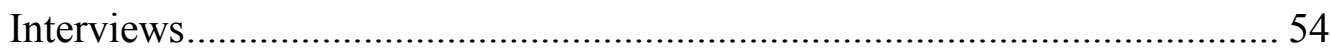

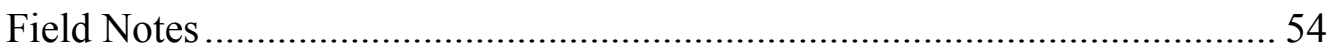

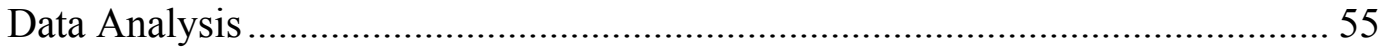

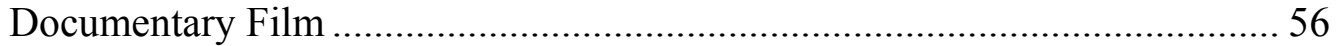

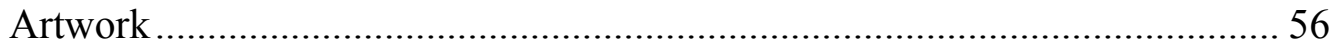

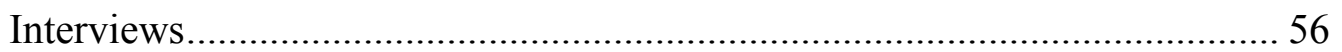

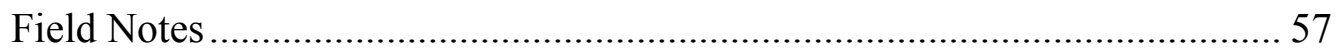

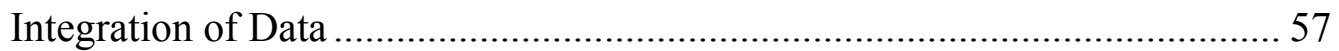

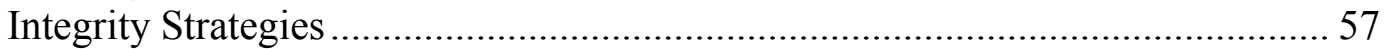

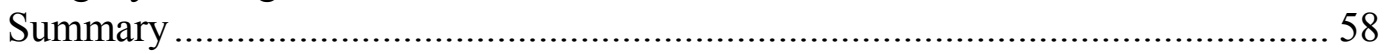

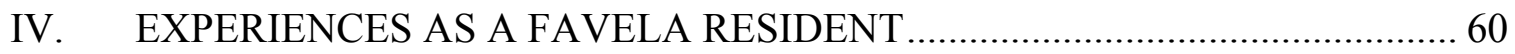

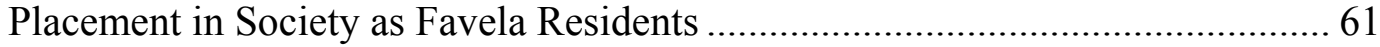

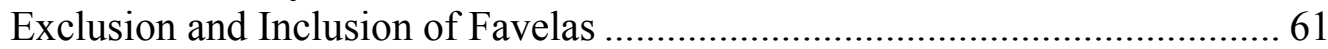

Societal Placement Communited through Semantics .................................... 73

Social Markers of Identity .............................................................................. 78

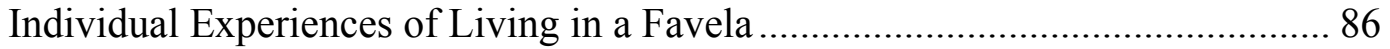

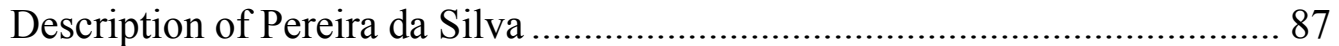

Discriminatory Experiences ......................................................................... 99

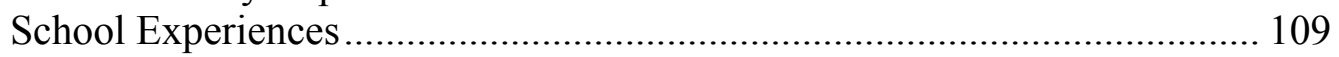

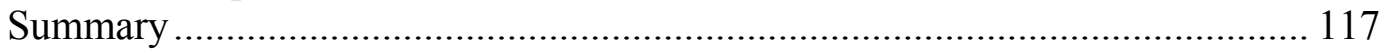

V. MORRINHO COMMUNICATING ON LIFE IN A FAVELA........................ 119

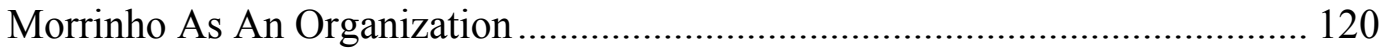

A Game, An Opportunity, A Social Project ………………........................ 121

Character Development ......................................................................... 135

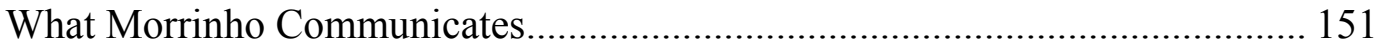

Nuanced Messages of Life in a Favela ...................................................... 152

Countering the Dominant Characterization of Favelas.................................. 164

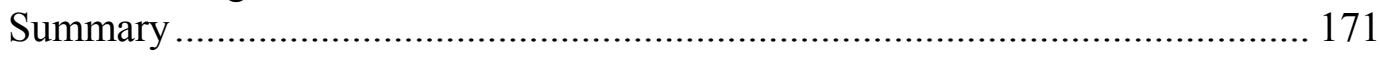


VI. DISCUSSION AND RECOMMENDATIONS ......................................... 173

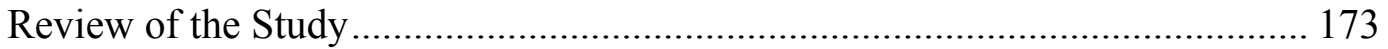

Discussion of the Research Question.............................................................. 176

Demonstrations of Personal Identity for Favela Residents.......................... 177

Violence in an against Favela Residents.................................................. 179

Discrimination for Favelas and Their Residents..................................... 182

Countering Discrimination in Action and in Discourse.............................. 184

Countering Through Art the dominant Characterization of Favelas ............ 187

Internal Character Development Associated with Morrinho ........................ 189

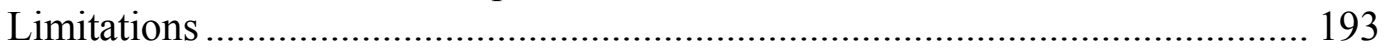

Recommendations for Practice and Policy .................................................... 193

Recommendations for Research ................................................................... 195

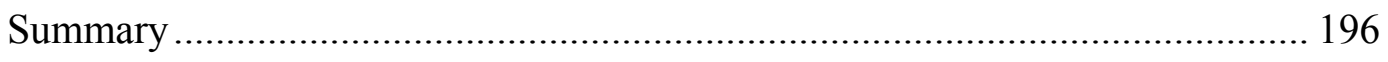

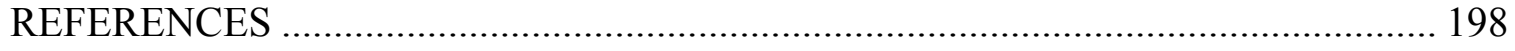

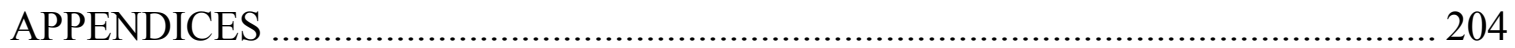

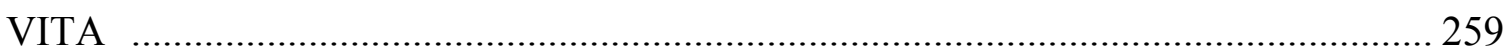




\section{PRELUDE}

I first came to know Morrinho, the arts based youth program that this dissertation is about, while I worked as one of the organization's volunteers in Rio de Janeiro. How I came to write this dissertation goes back more than a decade. My developing interest in marginalized populations, education, and Brazil was so slow and gradual, that I did not realize until recently how unlikely it was for me to research a group that is very much my other. I am a white, middle-class, American woman with a graduate degree. They are a mostly non-white, impoverished group of Brazilian boys and men, who mostly have not finished secondary school. The differences are many. However, all of us had grown beyond our family backgrounds through experiences with people that were different from us.

My initial interest in Brazil came when I took capoeira classes in 2001 when I was working as an English teacher in Rome, Italy. Already fluent in Spanish and Italian, I realized that I could understand and read Portuguese. A few years later, in 2004, I was studying for a master's degree in Latin American Studies at the University of Miami, and I took an introductory Portuguese class for Spanish speakers. I thought that I had succeeded in only learning great Portuñol, a mixture of Spanish and Portuguese. But that summer I enrolled in Fastforward Language Institute in Maceió, Brazil, and within a few weeks I had placed out of their advanced language classes.

In order for me to continue learning Portuguese, Fastforward paired me with a volunteer opportunity at Centro Erê, which ran a literacy school for the children of the Vila Brejal community. At the time, I did not know what a favela was, but I recognized the sudden shift to dirt roads and open sewage that differentiated the community from the 
neighboring city center. I also quickly found out the deep level of appreciation that the kids had for me when I helped out in their classrooms. This was something I had not witnessed in my previous three years of teaching experience. I also noticed the level of gratitude that the mothers had for me when I gave them printed photos of their children. I later understood that it was not common for the mothers to have many photos of their children, or any at all. It wasn't until after many warm receptions that I learned that the middle-class of Maceió regarded Vila Brejal as one of the least desirable places to live in the city due to the violence and drug trafficking associated with the community. While others used language that subjectified the residents of Vila Brejal, they were talking about people that I had come to value and identify with on a personal level.

During a period of three months, I continued to volunteer for the community school. I also had many conversations with Cristina do Nascimento, the founder and director of Centro Erê. Cristina arranged for me to visit a public elementary school where her husband worked, and the private school that her children attended. She also took me to the Maceió campus of the Universdade Federal de Alagoas, and introduced me to several education professors. These experiences planted and nourished my ideas of equality through education and the importance of community-based efforts.

Once back at the University of Miami, I pursued coursework and research on Brazilian education and social stratification. I wanted to give voice to a lesser-studied population, and I wanted to become better acquainted with the Brazilian people in the city that I was living in, so I wrote my master's thesis on Brazilian immigrant identities in Miami. This research allowed me to further understand Brazilian society and culture, and was my first real experience with original qualitative research. After finishing my 
master's degree, I pursued a career as a high school teacher in Miami. I explored the voices of many sectors of society in the World History, U.S. History, and Latin American History classes that I taught.

By 2009 I was still working as a high school teacher, and I had started the coursework for my doctoral degree at Florida International University. I was in need of an extended break from the hustle and bustle of my work and studies, so I decided to go to Rio de Janeiro for five weeks, a city that so many Brazilians in Miami told me that I had to visit. Through an organization called Iko Poran, which connects volunteers from around the world to work with NGOs (non-governmental organizations) in the favelas of Rio de Janeiro, I was connected with Morrinho, in the Pereira da Silva community. By the time that I met the Morrinho group, I was very eager to do all that I could to leave a sustainable positive impression.

The Morrinho team did not have a specific job waiting for me, and initially I did not have a good understanding of all that they did. After meeting Dani, a middle-class Brazilian woman who volunteered with Morrinho, I had a better idea of what I could do. I first translated from Portuguese to English a blog that Morrinho had been keeping for over two years. I then reconstructed Morrinho's already existing website to give them the option of changing the site to reflect the current status of the organization. I taught three of the Morrinho members how to work with the web-design program that I used. I was also a volunteer teacher at the Centro de Cultura, a small daycare center for the children of Pereira da Silva. There were a number of other volunteers who did this with me. We were all about the same age and all from North America and Europe, and we had similar ideas of service and valued international cultural experiences. 
When I returned back home to Miami, I redesigned Morrinho's website to give it the design of Morrinho's already existing promotional material, and I substantially expanded the content of the site. With the assistance of the two other volunteers and myself, Morrinho also gained an increased social networking presence on Facebook, Twitter, Orkut, Flickr, YouTube, and Wikipedia. In addition to this, I worked with one other American volunteer to incorporate Morrinho as a tax-exempt 501(c)3 organization in the U.S. in order to facilitate donations and promotion efforts. I was also able to organize a screening of Morrinho's feature-length documentary, God Knows Everything But He's Not A Snitch ${ }^{1}$, at the University of Miami's Cosford Cinema. Through this and other fundraising efforts, we were able to cover our initial incorporation costs as a 501(c)3 and we transferred the rest to Morrinho in Rio de Janeiro. They used the money to make repairs to the office building and for other administrative costs.

During my summer break of 2010, I returned to Rio. This time I rented a house in Pereira da Silva for eight weeks, and one of my longtime friends from the United States stayed with me for a month. I worked as a tour guide of the Morrinho model, helped with administrative duties concerned with getting a large government grant to start an educational component, and organized travel opportunities for the Morrinho team. As I was having my first experiences of living in a favela, I was able to unpack ideas with my old friend. I also made friends in Pereira da Silva, and with other English speaking expatriates who volunteered with favela-based NGOs in Rio de Janeiro. They all made me feel a bit more at home as we shared similar experiences.

${ }^{1}$ Deus sabe tudo mas não é X-9 
The summer of 2012 I returned to live in Pereira da Silva, and conducted my interviews for this dissertation. I rented a room in a house from the same gentleman whom I had rented from two years before. Living by myself in Pereira da Silva was different than what I had experienced two years earlier. I felt accepted for who I was by the Morrinho group, but that was not always the case for all who lived in Pereira da Silva. Some of the Morrinho participants who were my friends helped me to understand the social and cultural differences that I was experiencing. And again, through an extended network of former volunteers, I met middle-class expatriates and Brazilian friends that gave me a sense of normalcy while I researched a different class and culture than my own, in a different language. And I kept busy conducting interviews.

It was not easy coordinating my schedule with those of all of the 17 participants of this study. Often our concepts of time and priorities were not the same. Why was I able to interview the Morrinho group when other researchers had not been granted access? I do not know. I think that it was my previous support for Morrinho and my work with the children of Pereira da Silva that built trust and confidence. My coincidental networking with the families of the participants helped me to accomplish the 17 interviews in a four-week period. When a few of the participants couldn't seem to find the time for me, it was their mother, grandmother, girlfriend, wife, cousin or friends who encouraged them to find time for me.

I also think my timing was good. I met Morrinho the first year of an organizational structure change, which left the offices quieter and more heavily dependent on a volunteer force. By the time I conducted my interviews in 2012, the original eight Morrinho participants who had previously been focused on media attention 
and invitations to art exhibits, were now spending most of their time working other jobs to support their families. The nine other participants of this dissertation were younger than the original members, and had not had the experience of media attention and international travel that the original eight members had.

While this dissertation is on a group that is seemingly very different from me, I have taken over a decade-long journey to understand who they are on a societal and human level. Five of those years, I was a volunteer and friend of Morrinho. I have spent most of my adult life reaching beyond my white, middle-class, educated, American profile. Part of what this dissertation aims to reveal is the journey that the Morrinho participants took to go beyond their mostly non-white, non-middle class, not as formally educated, Brazilian profile. 


\section{CHAPTER I}

\section{INTRODUCTION}

This research study describes the experiences of living in a Rio de Janeiro favela as communicated by the participants of Morrinho, an arts-based non-formal education (NFE) program. Chapter 1 of this dissertation introduces the background of the study with the socioeconomic and educational contexts of Rio de Janeiro and its favelas. The study's framework is presented through the problem statement, purpose statement, research question, conceptual framework, and an overview of the methods. This is followed by the significance of the study, researcher's assumptions, delimitations, and definition of key terms.

An initial issue I was confronted with in this research was what a favela is to those who are not familiar with Brazil and to those whom do not speak Portuguese. I have read English translations of the term as "slum" or "shantytown," but in keeping with a framework of a critical ethnography, I believe that there is cultural and historic weight to certain words and in certain cases a direct translation is not possible. For this reason, in all direct quotes in Portuguese, I have left the synonyms of favela in the original form. The synonyms for favela are morro and comunidade, "hill" and "community". As will be further discussed in Chapter 4, the participants of this study do not use the term favela to refer to where they live, and there was discussion of the term being discriminatory when used by outsiders. When talking with me, the participants referred to Pereira da Silva as a morro or a comunidade. As a reflection of the critical theory applied in this dissertation, I use the terms "community" and "neighborhood" to refer to Pereira da Silva. I use the term "community" as a synonym for favela. I have translated all 
references to the asfalto, the formal city, by using that very word. I also use the terms "general population" and dominant society to refer to those who live in the asfalto. All translated direct quotes are footnoted with the original Portuguese.

\section{Socioeconomic Context}

Rio de Janeiro is Brazil's second largest city and is a cultural and economic center for the nation. However, scattered on the hills and suburban zones of Rio are an estimated 600 to 1,000 favelas, or informal housing settlements, where the city's impoverished live (Leeds, 2007; Perlman, 2010). Rio de Janeiro has Brazil's largest favela population and nearly all of them are controlled by one of three criminal organizations that aim to profit from drug trafficking, and dictate what life is like for favela residents. The factions monitor movement in and out of the favela, and act as a governing force when the city does not (Neate \& Platt, 2010). While most favela residents are not associated with the criminal factions, nearly all face societal discrimination as a result of the perception of being involved with the criminal activities. This belief is perpetuated by the dominant message of Brazilian press, radio, and TV, and is enforced by a militarized police force that represses the population (Neate \& Platt, 2010).

Brazil's social stratification is also one in which ethnic and racial minorities face discrimination. In his classic historical and sociological analysis of Brazilian identity, The Brazilian People, Ribeiro (1995) gave a broad description of Brazil's classes. In order to emphasize the large percentage of Brazilians living in poverty, a number that had been growing at a rapid rate at the time of Ribeiro's (1995) analysis, he classified those living in poverty as "the large mass of oppressed classes... principally Black and mixed- 
race, and live in favelas and the outskirts of the city" (p. 209). In quantifiable terms, when defining poor as living on less than half the minimum wage per month, Reiter (2009), found that "in 2004, 41.7 percent of Brazilian Blacks were poor, while only 19.5 percent of whites were in the same category."

The combination of poverty, social structure, and discrimination has led to intense public security concerns in Brazil. According to a study by the Observatório das Favelas, the Laboratório de Análise da Violência of the Universidade Estadual do Rio de Janeiro, the national Secretariat of Human Rights, and UNICEF, homicide is the principal cause of death for male youth between the ages of 15 to 24 . Homicides account for $40 \%$ of deaths for youth in Brazil, compared to $2 \%$ for the adult population (Lemle, 2011). Police tactics contribute to these figures. Instead of making arrests, police have been known to summarily execute suspects while on duty and attribute the death to someone who was resisting arrest, or kill their opponents while they are off duty (Goldstein, 2003). According to Denise Doura, program officer for the Brazil human rights initiative program of the Ford Foundation, "The killing of young people is one of the main humanrights problems in Brazil; both in terms of impunity and the public acceptance that allows police or others to carry out these killings" (Neate \& Platt, 2010, p. 452). This official policy of reinforced unequal power relations perpetuates societal discrimination of Rio's favela residents (Goldstein, 2003, p. 202; see also Mingardi, 1992). Males who are poor and Black or of mixed race comprise the majority of those who are involved in the criminal networks, the drug trade, and those who are homicide victims (Reiter, 2009). 


\section{Educational Context}

The school system further perpetuates the marginalization of Rio de Janeiro's urban poor. While nearly all school-aged children in Brazil enroll in school, an estimated $50 \%$ drop out by the time they reach the ninth grade. This translates to nearly $25 \%$ of Brazilians over the age of 15 being functionally illiterate, meaning that they can read and write, but cannot critically think from reading. Revealing racial divides, functional illiteracy is higher for Blacks than it is for Whites in Brazil (Ireland, 2007). All Brazilian public schools deal with regular administrative turnover. Teachers have heavy workloads, low pay, and high burnout rates. Student absenteeism is high, as are incidents of drug use, illiteracy among parents, and violence in schools (Gatti \& Barretto, 2009; Reiter, 2009). In schools located in or near Rio's favelas, teachers and administrators must negotiate for control of the school with the local criminal networks (Abramovay \& Rua, 2002; Guimarães, 1998; Leeds, 2007).

In order to supplement the education of the large percentage of marginalized youth, hundreds of non-formal education (NFE) programs operate in the city of Rio de Janeiro (Entidades Cadastradas, n.d.). NFE in Brazil generally works with marginalized populations in art and leisure to build self-esteem and identity, and falls under the classification of popular education. Programs are developed with a flexible curriculum that focuses on the needs of the local community (Ireland, 2007).

One such program is run by the Morrinho organization, based in the Pereira da Silva community in the South Zone of Rio. Morrinho uses visual and performing arts to portray male youths' vision of life in a Rio de Janeiro favela. The common description of Morrinho is as a social and cultural project. However, this research study positions 
Morrinho is an education site where participants dialogue about their place in society. Morrinho's principal site is a 370 square meter model made of painted bricks that portray Rio's favelas as they can be seen in the surrounding hillsides. Morrinho, which literally means "little hill", is also an affectionate term for a Rio favela or morro. The Morrinho model was started as a game for a group of young adolescent boys to escape from the urban warfare that their community was experiencing while the government aimed to stomp out the local organized crime network. Since its beginnings in 1997, Morrinho has remained a site of play for dozens of boys where they use Lego characters to act out favela culture as they themselves view it. The Morrinho participants also produce films set at the model and travel showing their work as art and cultural production. However, often they are asked to portray the violent and stereotypical visions of favelas, and are commonly not given a platform to communicate the nuanced issues associated with where they live. What is more, there is more international than Brazilian interest in the Morrinho work, suggesting their level of being silenced in Rio de Janeiro and Brazil.

\section{Problem Statement}

Several scholars have discussed the importance of identity building and cultural pride to increase self-esteem and combat the negative influences that can impact impoverished urban youth (Gohn, 2007; Neate \& Platt, 2010; Perlman, 2010). Visual arts, music, film, and theater are recognized as positive identity building activities and many NFE programs use these art forms as a basis for their curricula. However, there is scant literature detailing these programs in Rio de Janeiro or in Brazil (e.g., Gohn, 2007; Hoppers, 2006). This lack of literature contributes to the experiences of impoverished 
urban Brazilian youth not being adequately voiced. This study aimed to address the gap in the literature on NFE programs in Rio de Janeiro.

\section{Purpose Statement}

The purpose of this visual critical ethnography was to examine the Morrinho participants' experiences of living in a Rio de Janeiro favela as communicated through their film, artwork, and words.

\section{Research Question}

The main research question is

- What are the experiences of living in a Rio de Janeiro favela that the Morrinho participants communicate through their film, artwork, and words?

\section{Conceptual Framework}

The conceptual framework of this dissertation takes a critical look at unequal power relations which, due to historical and political reasons, maintain a socially stratified society (Carspecken, 1996; Kinchecloe \& McLaren, 1994). Central to this critical stance is the belief that education is a powerful mechanism that can work in a dialogical fashion to bring a mutual understanding to both the oppressor and the oppressed (Freire, 2009). A critical pedagogy can lead to the development of a critical consciousness, or in the terminology of Brazilian theorist Paulo Freire (2009), conscientização, which can work to create a balance of power for all societal actors. Inherent in conscientização is the idea of class mobility, which can be explained by the concept of habitus. An unconsciously acquired internalized structure, habitus holds that a person's taste in culturally symbolic resources, such as art, style, and linguistic patterns, 
signals what social class a person belongs to (Bourdieu, 1977). A person's internalized structure also acts to shape expectations and life chances (Swartz, 1997). A person is able to transcend his or her structure through personal agency, and adopting the demonstration of taste of the dominant class, which is possible through a critical pedagogy (Bourdieu, 1977; Freire, 2009).

\section{Overview of Methods}

This visual critical ethnography is comprised of deep descriptions and a conceptual lens that challenges the entrenched power relations in Rio de Janeiro while placing an emphasis on the analysis of film and photos. In order to increase the credibility of this study several sources of data were collected: (a) the documentary film of the Morrinho organization, God Knows Everything But He's Not A Snitch; (b) photos of the Morrinho artwork (See Appendix C); (c) individual interviews with the Morrinho youth; and (d) researcher's observations of what daily life is like for the Morrinho participants in Pereira da Silva.

The data were analyzed by a multi-step process where meaning fields, possible meanings, and truth claims, ways of seeing, were interpreted based on the context of the discussions with the participants and the observations taken (Carspecken, 1996). The results of the analysis of each source of data were considered in order to determine what were the most trustworthy interpretations of truth claims. Macro-level analysis was conducted by applying social theories of critical theory, critical pedagogy, and habitus to explain the unequal power relations that male favela youth experience in Rio de Janeiro. Several integrity strategies were used to enhance the credibility of the analysis and conclusions (Patton, 2002). Throughout the research process, I kept a reflexive journal in 
order to bring my own consciousness into focus (Lincoln \& Guba, 1986). Triangulation of data was accomplished by the use of multiple sources of data and a multi-step analysis process (Denzin, 1970). Member checking was established (See Appendix E) by checking my initial analysis and conclusions with the Morrinho participants in person and via email (Merriam, 2002). Finally, I maintained a clear audit trail that was checked by the members of my doctoral dissertation committee (Patton, 2002).

\section{Assumptions}

This study has several assumptions that are based on my own worldview, and my previous experience working with the Morrinho organization.

- I believe that the youth opinion is to be considered and respected.

- I believe that youth are capable of critical thinking and action more often than they are given credit.

- I believe that the cultural structure of non-dominant classes is as valuable and rich as the cultural structure of the dominant classes.

- I believe in the ability of any person to improve his or her life chances, if provided with the opportunities to do so.

\section{Delimitations of the Study}

This study is a visual critical ethnography looking at the experiences of 17 participants of the Morrinho organization. I examined the documentary film of the Morrinho project, photos of the Morrinho artwork, the viewpoints of 17 of the Morrinho participants, and my own researcher observations. This study concentrated on the film and art of Morrinho, and not explicitly on the production process, the tourism aspect of 
the project, or the organization's efforts to teach film to newer generations of youth in the Pereira da Silva community.

\section{Definition of Terms}

Below is a list of specialized terms that will be referenced. The words in Portuguese are italicized below, and throughout the dissertation.

1. Amigos de Amigos (ADA). A drug trafficking criminal network in Rio de Janeiro (Neate \& Platt, 2010).

2. Asfalto. Refers to the incorporated area of Rio de Janeiro that is not part of a favela.

3. Carioca. Name given to a resident of the city of Rio de Janeiro.

4. Comando Vermelho (CV). The oldest drug trafficking criminal network in Rio de Janeiro (Neate \& Platt, 2010).

5. Conscientização. Paulo Freire's term for a critical consciousness (Freire, 2009).

6. Critical pedagogy. Theory applies a belief that unequal power relations are reproduced in education, and should be challenged (Friere, 2009).

7. Critical theory. Theory that views unequal power relations being reproduced in society, and argues that they should be challenged (Kinchecloe \& McLaren, 1994).

8. Cultural capital. A term of the theory of habitus that there exists a dominant culture, and fluency in the dominant culture as a kind of social capital (Bourdieu, 1977).

9. Ethnography. A research method that defines culture by in depth analysis (Carspecken, 1996; Pink, 2007). 
10. Faction. A type of criminal network.

11. Favela. Brazilian term for an area of informal living, a squatter settlement, a shantytown (Perlman, 2010).

12. Favelado. A person who lives in a favela.

13. Functionally literate. Describes someone who can critically think based on what he or she reads. Generally has completed the fourth grade (Ireland, 2007).

14. Funk music. A style of music popular with favela youth in Rio de Janeiro. Has a three-beat rhythm and songs are rapped (Yúdice, 2003).

15. Funkeiro. A type of style and identity of someone who listens to funk music (Yúdice, 2003).

16. Gente. In Portuguese means "somebody," but the term is also a signal as being included in part of a group (Perlman, 2010).

17. Habitus. A structure that maintains class divisions, includes a person's culture (Bourdieu, 1977).

18. Meaning reconstruction. A process by which underlying meanings emerge by reading through the primary record of data (Carspecken, 1995).

19. Member checking. A qualitative research integrity strategy where interpretation of data is checked with the participants of the study (Denzin, 2009; Merriam, 2002).

20. Morrinho. Means "little hill" in Portuguese, in Rio de Janeiro can be an affectionate term for a favela. 
21. Non-formal education. A type of education that supports traditional education, generally works with marginalized populations, uses flexible curriculum that focus on the needs of the local community (Gohn, 1999; Hoppers, 2006).

22. Normative-evaluative truth claims. Societal agreement to what is valued and what is appropriate (Carspecken, 1995).

23. Objective truth claims. Objects and events to which all people have direct access (Carspecken, 1995).

24. Preto. When used as a racial identifier, refers to a person who is very dark skinned (Telles, 2004).

25. Primary record. The list of all of the objective truth claims. Is the basis for all subsequent analysis and is made up of thick and less thick records (Carspecken, 1995).

26. Proibidão. A sub-category of funk music that glamorizes the drug trade, violence, and criminality (Sneed, 2008).

27. Subjective truth claims. The state of mind and feeling to which only one person has direct access (Carspecken, 1995).

28. Terceiro Comando (TC). A criminal network in Rio de Janeiro (Neate \& Platt, 2010).

29. X-9. Term refers to a "snitch" in Brazilian slang (Neate \& Platt, 2010).

\section{Summary}

Rio de Janeiro is a city that is deeply divided along social and economic lines.

The male youth who live in the city's favelas, often Black or mixed-race, are marginalized by being the most common victims of homicide related to drug trafficking 
and police abuse. Favela youth are also more likely to live in poverty, are highly likely to drop out of school, and are less likely to be literate. In this context, hundreds of NFE programs work with the favela youth in Rio de Janeiro in order to supplement what education they receive in school with curricula based in the arts and leisure, and programs are rooted in the needs of the local community. The Morrinho organization is one such NFE program. The Morrinho participants are all male, many are Black or mixed-race, and are all from the Pereira da Silva community.

This study examined the participants' experiences of living in a Rio de Janeiro favela as communicated through their film, artwork, and words. A multi-step critical ethnographic analysis was used to interpret truth claims. Macro-level theories of critical theory, critical pedagogy, and habitus were used to explain the unequal power relations experienced by the Morrinho participants as residents of Pereira da Silva. This study was undertaken to give voice to one of Rio's most marginalized populations and to contribute to the currently narrow breadth and depth of literature on NFE in Brazil. 


\section{CHAPTER II}

\section{REVIEW OF THE RELATED LITERATURE}

This study describes the experiences of living in a Rio de Janeiro favela as communicated by the participants of the Morrinho organization. This chapter is designed to give the reader a deeper understanding for the theoretical framework, the setting of study, and other research that has been conducted on NFE programs in Brazil. This chapter is divided into four general sections: (a) theoretical framework; (b) issues of exclusion and inclusion of Rio's favelas; (c) demonstrations of culture associated with Rio de Janeiro's favelas; (d) challenges to Brazil's formal education system; and (e) a structure of NFE, including how it has developed in Brazil. The chapter concludes with a review of previous literature on the Morrinho organization and it's setting in the Pereira da Silva community.

\section{Conceptual Framework}

The conceptual structure of this dissertation takes a critical stance at Rio de Janeiro's unequal societal power relations (Kinchecloe \& McLaren, 1994). Inherent in this stance is a critique of traditional models of education, which nearly always embrace the values and traditions of those who are already in power. This reinforces unequal power relations and keeps power away from those who are oppressed along social and economic lines (Freire, 2009).

\section{Critical Theory}

Critical theorists are concerned with social inequalities, including "the nature of social structure, power, culture, and human agency" and use their research to go beyond describing social life by aiming to refine social theory (Carspecken, 1996, p. 3). 
According to critical theorists, power relations are socially and historically constituted and mediate all thought. Critical theorists believe that in any society certain groups are more privileged than other groups, and this inequality is reproduced when the oppressed groups accept their social status. This results in the subjectification of the groups with less power in society (Kinchecloe \& McLaren, 1994). Unequal power relations distort the truths that different members of society will believe in. A critical epistemology requires rigorous standards to differentiate between the different kinds of truth claims: subjective, objective, and normative evaluative. Subjective truth claims are the state of mind and feelings to which only one person has direct access. Objective truth claims are events to which all people have direct access. Normative evaluative truth claims are societal agreements to what is valued and what is appropriate activity. In the analysis of this study, the Brazilian society, and the specific context of Rio de Janeiro, was used as a basis for forming normative evaluative truth claims. Critical epistemology looks to understand what kinds of support are required for each of the three types of truth claims. Critical theorists examine larger societal structures that are rooted in everyday human communication (Carspecken, 1996).

\section{Critical Pedagogy}

Critical pedagogy applies the belief in unequal societal power relations to the educational context. Schools are microcosms of the larger society and can "produce social turmoil by maintaining dominant beliefs, values, and interests - cultural identities - through particular bodies of knowledge, pedagogical practices, and curricula" (Leistyna \& Woodrum, 1996, p. 3). Critical pedagogues believe that education is a powerful societal tool to perpetuate the status quo, or to work toward a more equal society by 
mobilizing the human agency of students. Critical pedagogy encourages a space where students and teachers can dialogue openly about any social practices or government policies that "produce and sustain inequalities and oppressive social identities and relations" (Leistyna \& Woodrum, 1996, p. 7). Traditional models of education are aligned with what Freire (2009) called the banking concept, where "knowledge is a gift bestowed by those who consider themselves knowledgeable upon those whom they consider to know nothing" (p. 72). As an alternative to the banking concept of education, critical pedagogy focuses on problem-posing education based on creativity and reflection on individual histories to bring the students to a stage that Freire (2009) called conscientização, the raising of a critical consciousness. Dialogue is a necessary part of critical pedagogy in order for the oppressor and the oppressed members of society to recognize where they stand in the given social order, so they can work to create a more equal balance of power and liberation for all actors of society (Freire, 2009). Inherent in critical pedagogy is a discussion of class mobility, which can be further explained by a discussion of habitus.

\section{Habitus}

Habitus is a historically rooted structure that refers to the maintenance of class divisions (Bourdieu, 1977). The concept of habitus goes beyond economic differences and looks at a person's taste in social markers, like music, art, style and linguistic patterns, that compose the cultural structure which demonstrate what social class someone belongs to. Habitus is an unconsciously acquired internalized structure "that derives from the class-specific experience of socialization in family and peer groups" (Bourdieu, 1977, p. 102). A person's structure shapes their individual action and 
translates to individual aspirations or expectations, which reproduce their life chances (Swartz, 1997). The culture, or habitus structure, of a society that has the ability to endure throughout time is termed to be cultural capital. If a society lacks the cultural literacy to accumulate and preserve cultural resources, then those resources will not be incorporated by the state and adopted by the educational system (Bourdieu, 1977). Habitus is viewed as relatively unchanging, however personal agency is considered to be a way by which an individual may change her social standing. A person may transcend their habitus by adopting the rules, patterns, and behavior of a different habitus. This changing of habitus, however, is considered more difficult for the lower socioeconomic class individuals (Bourdieu, 1977). One of the surest ways to transcend habitus is education, because "academic qualifications are to cultural capital what money is to economic capital” (Bourdieu, 1977, p. 187).

\section{Exclusion and Inclusion of Favelas}

Rio de Janeiro has the largest favela population of any Brazilian city, 19\% of all municipal residents, accounting for one-fourth of the favela population for all of Brazil. São Paulo, the only Brazilian city larger than Rio, has a smaller overall favela population, and a lower proportion living in favelas, 9\% of all residents (Perlman, 2010). To describe the deep contrasts of Rio de Janeiro, Goldstein (2003) wrote "poverty, inequality, racism, and violence are everywhere" (p. 27). According to Jaguaribe (2009), the upper classes have retreated into "fortified enclaves protected by guards, gates, and electronic surveillance" (p. 22). Arias (2004) argued that favela residents must rely on criminal networks and social networks to protect themselves. The presence of criminal networks, factions, in Rio de Janeiro's favelas has caused the anxiety over inequality and violence 
to be focused nearly entirely on drug trafficking and organized criminal activity (RothGordon, 2009). Published just before Rio's recent security efforts for the 2014 World Cup and that 2016 Olympics, Perlman (2010) reported that factions control nearly all of Rio's 1,020 favelas.

\section{Criminal Networks}

Currently three criminal networks control the favelas of Rio de Janeiro: the Comando Vermelho (CV), the Terceiro Comando (TC), and the Amigos de Amigos (ADA). These three factions all aim to profit from drug trafficking (Neate \& Platt, 2010). The favelas which are not controlled by one of these three factions are controlled by militias of vigilante off-duty police officers (Neate \& Platt, 2010). These four groups are the most visible criminal networks in the city. However, Neate and Platt (2010) and Goldstein (2003) found that among favela residents, drug consumption is viewed negatively, signaling gang membership, indebtedness, or addiction. In their effort to identify a common favela state of mind, Neate and Platt (2010) wrote, "While the vast majority of residents don't see $o$ tráfico as a 'good thing'... they do recognize its temptations and are inevitably immersed in its culture" (p. 145). It is nearly impossible to forget the presence of the traffickers, since tagged on the walls of every favela are the letters CV, ADA, or TC, to denote which faction is in control.

The factions control favela life in a number of important ways. They monitor who enters and exits the favela. If a resident of a favela controlled by one faction wants to visit someone in a favela controlled by another faction, he risks his life even if he is not directly involved in the trafficking (Neate \& Platt, 2010). What is more, since the government does not effectively have control over the rule of law in the favelas, the 
traffickers serve as the closest thing to a local government (Arias, 2004). The favela residential associations, NGOs, churches, and schools all must negotiate their plans and operations with the local drug lord (Arias \& Rodrigues, 2006). The factions resolve disputes between residents; sponsor local funk dances; and provide residents with minimal social services such as financial assistance for funerals, water services, and vans providing transportation to and from stores and hospitals (Arias \& Rodrigues, 2006). It is in these ways that the traffickers build feelings of gratitude and obligation in favela residents, furthering their institutionalization as political and social leaders (Arias \& Rodrigues, 2006; Neate \& Platt, 2010).

While sometimes acting as a mediating force in favelas, the traffickers also create an atmosphere of violence. Crimes such as robbery, rape, and interpersonal violence are often met with an equally violent reaction by the traffickers (Arias \& Rodrigues, 2006). Anderson (2009) reported that less than two weeks after Rio won the bid for the 2016 Olympics, violence broke out, and lasted for days. In protest of police presence, the factions burned ten city buses and other vehicles, and shot down a police helicopter with what was "believed to be a .30 -caliber anti-aircraft gun, a powerful weapon normally used by armies in war zones like Afghanistan" (Anderson, 2009, para. 1).

\section{Police in Rio de Janeiro}

Police in Rio have historically and routinely brutalized the poor by using methods such as "torture, coerced confession, extortion, and other physical punishments, including execution" (Goldstein, 2003, p. 202; Human Rights Watch, 2009). These police tactics combined with the warfare between factions are largely responsible for the youth homicide rate in Rio, which in 2002 was at a 10 -year high of 145.5 per 100,000, but 
dropped to 41.4 per 100,000 in 2011. For comparison, for the same period of time the same rates for the general population was 62.8 per 100,000 in 2002, and 23.1 per 100,00 in 2011 (Waiselfisz, 2013). Another study reported that the concentration of favelas contributed to the homicides in the West and North Zones of the city being eight times greater than in the wealthy South Zone (Arias \& Rodrigues, 2006). Rio de Janeiro police stand out for their levels of resistance killings (when victims were killed after allegedly firing at police), but Human Rights Watch (2009) found evidence to support that a "significant portion" of cases reported as resistance killings were likely extrajudicial executions (p. 21). The targeting of the police is rarely indiscriminate. Other studies have shown that young males of all classes are routinely subject to discrimination, but middle class or White youth "are routinely shaken down for a pay-off, while Black youth are physically abused" (Leeds, 2007, p. 29).

Low salaries and little formal training contribute to the cycle of corruption and violence of which the police are a part. The police often live in favelas themselves, and must live amongst a population who does not trust anyone in their profession (Neate \& Platt, 2010). Marina Maggessi, with the Rio police, says that a police officer who lives in a favela cannot tell anyone what his profession is for fear of being killed, and his children bullied and harmed (Neate \& Platt, 2010). Luiz Eduardo Soares, researcher at the Institute for the Study of Religion (ISER) and former National Secretary for Public Security, explained that there are a total of 45,000 civil and military police in Rio, but each organization has its own culture, which functions to create competition instead of harmony amongst law enforcement (Neate \& Platt, 2010). According to Soares, "You 
are nourishing a monster in the police, and this monster becomes part of criminality" (Neate \& Platt, 2010, p. 122).

\section{Discrimination}

While the criminal factions and the police cause a large portion of the security problems for favela residents, societal discrimination also contributes to the many challenges that residents face. In Carnival, Rogues, and Heroes, Da Matta (1991) referred to a popular Brazilian dictum to explain Brazilian society: "For individuals, the law; for persons, everything!” (p. 186). This explains the attitude that the police have toward the poor, but it also explains the largely held perceptions of the difference between an "individual" and a "person". A person is considered someone with social connections, a good education and job, and one who lives in a good neighborhood. An individual is someone without personal connections, who must show a national ID card to be recognized as somebody, and is generally someone not pertaining to the dominant class. As the phrase goes, persons in Brazil dodge the law and face no repercussions. Individuals in Brazil are subject to the law and often face the strictest penalties (DaMatta, 1991).

Perlman (2010) explained that the Portuguese word gente means "somebody," or in Da Matta's (1991) terms, a person. Gente is also used in Portuguese to mean "we," an inclusive term, which denies being othered. Many of the favela residents that Perlman (2010) interviewed had the goal of being gente, but the "marginalization of Rio's poor is so extreme as to exclude them from the category of personhood" (Nilton, para. 1). Perlman (2010) also found that the largest basis of discrimination was being from a favela, then race, then appearance (including a person's speech patterns and appearance), 
which denotes someone's personhood in public spaces. Both Perlman (2010) and Neate and Platt (2010) referred to Ralph Ellison's Invisible Man, first published in 1947, to describe the current societal view of Rio's favela residents. Neate and Platt (2010) and Perlman (2010) communicated that favela residents are treated as silenced citizens in Rio de Janeiro today.

Race also plays a part in the marginalization of favela residents. In Rio de Janeiro, Blacks are more likely to live in the favelas than are other racial or ethnic groups (Gates, 2011). Neate and Platt (2010) quoted extensively Jailson de Souza, the director of the Observatório das Favelas, an influential think tank. De Souza explained that while interracial marriages are more common in the favelas, there still exists racism. "In Nova Holanda (in Maré), if you go to the poorest part of the favela eighty percent of the population is preto [dark black].... It's harder for pretos to get jobs. There's still a racist stereotype that stigmatized Black Cariocas [residents of Rio de Janeiro] as lazy" (Neate \& Platt, 2010, p. 76). Goldstein (2003) found evidence that the structures of racism in Rio de Janeiro are present in everyday experiences "often conveyed through indirect forms of communication - Black-humored jokes and codes of silences" which are difficult to describe and challenge (p. 105).

Employment discrimination is widespread and a factor that directly affects the poverty level of favela residents. All things being held equal, salaries of men living in favelas of Rio are 35\% lower than for non-favela residents, and Black men from favelas earned 50\% less than Black men that did not live in a favela. In order to avoid this job discrimination, many adults and youth who live in favelas change their address on job applications with the purpose of avoiding discrimination (Leeds, 2007). 
While being recognized as people, and job discrimination are large issues for Rio favela residents, Neate and Platt (2010) found that one of the biggest challenges that cultural NGO AfroReggae combats is the media's perpetuation of the othering of favela's residents. Paulo Baia, Undersecretary for Human Rights for the State of Rio de Janeiro and professor at the Universidade Federal de Rio de Janeiro, supported this perceived challenge:

Over the years the favelado [favela resident] has been transformed into a synonym for a criminal. This vision is reinforced by the Brazilian press, radio, and TV. Obviously this has a negative impact on the lives of the population who suffer violent and racist repression at the hands of the police.... Consequently, we are faced with a situation where two million people suffer various abuses every day lack of transport, health, and education, as well as police oppression. (Neate \& Platt, 2010, p. 149)

\section{Integral Part of Society}

Many scholars point to the deep divisions within Rio de Janeiro, but also to how the upper classes depend on favela residents to maintain their lifestyle. Referring to her 1980 book The Myth of Marginality, Perlman (2010) found that after 35 years, the myth has turned to a "reality of marginality" (Conclusion, para. 1). However she asserted that Rio is not a strictly divided city and that the two sides are "interdependent and intertwined" (What's In a Name?, para. 2). Neate and Platt (2010) stressed that despite favela residents having been systematically excluded from wider society, they "make Rio tick. They work formally in construction, factories, or on the buses. They work informally as cleaners and handymen. They work criminally, selling the pirated goods 
available on every street corner" (Neate \& Platt, 2010, p. 75). Goldstein (2003) found that a class marker for the middle class and elites is employing domestic help. Nearly all domestic workers are women from favelas, and a large proportion are Black, signaling that they are among the most disadvantaged workers. Despite this divide, many middle class and elite Brazilians talk about their domestic help with affection and love for nannying their children, cooking their favorite meals, and anticipating needs before they arise (Goldstein, 2003).

Despite being an integral part of Rio's society, the complex favela/asfalto dichotomy makes it so that most from the asfalto never set foot in a favela. However, since 1992, there has been a growing tourism industry that attracts mostly international visitors who wish to experience favela life firsthand (Freire-Medeiros, 2005). Rocinha, Rio's, and one of Latin America's, largest favelas, has been visited by such high profile people as "the queens of Sweden and Denmark, Princess Diana of England, Bill Clinton, Mikhail Gorbachev, the Pope, and President Ignácio Lula da Silva” (Perlman, 2010, Favela Tourism, or "Poorism", para. 4). Favelas are now registered as tourist destinations with the Rio Tourism Office (Freire-Medeiros, 2009).

What do visitors see when they enter a Rio favela? Definitely not the desperate poverty and starvation that may be found living informally in other parts of the world. According to 2001 figures for Perlman's (2010) study, 98\% of favela residents have televisions; $97 \%$, refrigerators; $85 \%$, stereos; and $22 \%$ have personal computers (Perlman, 2010). Many of the houses in favelas are solidly and creatively built, and in some cases part of a flourishing real estate market (Neate \& Platt, 2010; Perlman, 2010). Whereas the asfalto is evidently planned and grid-like, the favela is curvilinear, reflecting 
growth as is best fit for the residents' needs and the contours of the land. There tends to be many individual structures at all stages of construction, and buildings set at various angles that bend with the scape of the land to catch a breeze, shade from a tree, or a great view (Perlman, 2010).

\section{Demonstrations of Culture in Favelas}

Many scholars have asserted that identity building is a necessary process to combating the social ills common to favela youth, principally dropping out of school, early pregnancies for the girls, and joining a faction (Leeds, 2007; Neate \& Platt, 2010; Perlman, 2010). Leeds (2007) explained that the reason why so many male favela youth join a faction is for the sense of an identity, prestige, and belonging that can go along with such an association. Perlman (2010) quoted Luiz Eduardo Soares as making this same point: "In the end, there is a hunger more profound than physical hunger; the hunger for affection, recognition, self-esteem" (Poor and Rich in People's Hands, para. 9). To Neate and Platt (2010), Soares said "If you are a teenager, you are at a difficult point in your life in terms of identity-building” (p. 150). If you are Black and poor in Brazil, “people don't see you. They neglect your presence or even project a negative image onto you... you point that gun at someone, you produce a reaction in your victim and... you become a person, you appear, you are visible" (Neate \& Platt, 2010, p. 150). When considering positive influences in building identity in the youth of Rio's favelas, hip hop and funk music, and style of speech are frequently discussed.

\section{Hip Hop Music}

Hip hop music has been used around the world to communicate a local reality (Fernandes, 2011). Specifically in Brazil, hip hop has been used widely to contest the 
subordinate place of Black people in Brazil and form an identity for marginalized youth (Pardue, 2008; Yúdice, 2003). Early Brazilian hip hop modeled itself after early U.S. artists and activists that asserted a Black identity. As Brazilians adopted their own style of hip hop, and linked with the Unified Black Movement (MNU) in the late 1980s in São Paulo, the style started being associated with leftist and Black power ideologies. Brazilian hip hop tells stories of life of run-away slave communities (quilombos), being Black in Brazil, and challenges Brazil's popular perception of racial identity. The popularization of hip hop in Brazil grew as "hip hoppers" worked closely with the MNU; liberal political parties, most notably the Labor Party (PT) and the Green Party (PV); NGOs associated with the women's and Black women's movement; and state departments of culture, education, labor and health (Pardue, 2008).

In his ethnography of São Paulo hip hoppers, Pardue (2008) found that virtually all were invested in telling the reality that they knew with the aim of legitimating and possibly empowering themselves while telling their stories (mainly of race and class) to mainstream Brazil. Common themes of hip hop narration include police brutality and corruption; and the scarcity of schools, libraries, cultural centers, and social services. There is a common theme among São Paulo hip hoppers of a collective solidarity to denounce the social ills they must confront. Pardue (2008) referred to a study that estimated that there were an approximate 5,000 hip hop performance groups in São Paulo alone, and that tens of thousands of youth looked to hip hop to shape or confirm their identities. Yúdice (2003) explained how hip hop has become the basis for a youth development ideology in numerous NGOs in both Rio de Janeiro and São Paulo, but devoted much of his research to funk music in Rio de Janeiro. 


\section{Funk Music}

As hip hop is aligned with the culture of marginalized youth in São Paulo, funk music is what is popular with favela youth in Rio de Janeiro. The sound of funk has its roots in raw Miami bass coming from underground music scenes in the late 1970s and 1980s. As opposed to most Western music that has four beats, funk has a three-beat rhythm and the lyrics are usually rapped and sung by an emcee. Yúdice (2003) found that funk does not deal with social injustices as overtly as hip hop music does, but it is a way that favela youth in Rio de Janeiro deal with racism and social exclusion while plugging into a larger social movement. Similar to hip hop, socially aware funk emcees address everyday violence, and talk of a social reality that is not commonplace for a middle class Carioca. In 1992, Rio's Secretary of Social Development Wanda Engle, in collaboration with other municipal secretariats and NGO activists, launched a program called Rio Funk. The goal of the project was to use funk music as a vehicle for developing creativity and ideas of citizenship for favela youth (Yúdice, 2003). While this project was largely popular, funkeiros are generally reluctant to be political. However, the fact that tens of thousands of marginalized Black and mixed-race youth follow funk, the musical style can become a strong challenge to the dominant culture of Rio de Janeiro. Yúdice (2003) argued that currently funk is largely an untapped source for a larger social and political purpose.

While developing into a popular form of personal and political expression, funk music also has a much darker side. The factions often organize and finance funk dances in the main meeting squares of the favelas that they control. Neate and Platt (2010) found that this secured their power within the community because the dances are popular, 
and the dances drew customers to the drug trade. A sub-category of funk music called proibidão (prohibited funk) glamorizes the drug trade, violence, and criminality (Neate \& Platt, 2010). Proibidão is also used to communicate the rules of the factions. According to a former member of the $\mathrm{CV}$, turned activist, "The rappers tell you the rules of the favela: that rape is forbidden, that you can't steal inside the favela or commit robberies nearby. And they'll tell you what happens to X-9s [snitches]" (Neate \& Platt, 2010, Prohibited funk, para. 4; see also Sneed, 2008). As an assertion of oppositional identity, funk music often rejects the traditional values of middle-class Brazil and professes favelas as legitimate spaces of personhood (Sneed, 2008).

\section{Style of Speech}

Speech pattern and word choice is an important marker of culture for its richness in symbols that identify the speaker's ideas, beliefs, and values. According to Hall (1997), such symbols include "sounds, written words, electronically produced images, musical notes, and even objects" (p. 1). Williams (1994) used the example of cultural generations being defined when it is found that one generation has different speech patterns and language register than another. Goldstein (2003) found that her middle class respondents often noted the different speech patterns and vernacular of their hired help. According to Roth-Gordon (2009), favela youth are aware that their register of slang can identify them as a favela resident. Yet, she found that slang expressions first used in the favelas eventually "trickle down the hills of Rio de Janeiro" and become popular with residents of all classes (Roth-Gordon, 2009, p. 62). 


\section{Formal Education in Brazil}

National education systems are commonly regarded as the most likely source for forming a national identity, transforming the existing national culture, and molding the political culture of the nation (Gohn, 1999). However, Brazil's school system has been widely criticized for reproducing the unequal status quo. Currently over $80 \%$ of schoolage children attend public school, however any parent who can afford to sends their child to a private school (Reiter, 2009). The nation's most prestigious universities are public and free of charge, but a compulsory public education does not prepare a student to satisfactorily meet the requirements to the public universities. There is a nationwide entrance exam, called the vestibular, that is so competitive that many kids from middleclass and elite families take a year off from school to study for the test. Poor families cannot afford this and often need their children to work, so those impoverished children who do take the vestibular often do not score well enough to be accepted to an institution of higher education. Reiter (2009) asserted that the vestibular serves to keep "graduates of public schools and those applicants unable to afford private prep-courses out of Brazilian colleges and universities" (p. 60).

\section{Education Quality}

Currently, primary education in Brazil is grades 1 through 9, and is compulsory for ages 7 through 14. It is comprised of four years of elementary education and another four years of intermediate education (Reiter, 2009). A recent study by UNESCO showed that nearly all Brazilian children enroll in first grade, but by fourth grade $24.1 \%$ of them drop out or stop out of school, and nearly $50 \%$ of Brazilians over the age of 15 have not concluded eighth grade (Ireland, 2007). A World Bank study found that girls tend to stay 
in school longer than boys. Attendance for girls remains high until age 17, but it drops to around $80 \%$ for boys by the age of 13 . There is sharp drop for boys to $50 \%$ by the age of 18 (Cardoso \& Verner, 2007). There is no significant difference in race for those who drop out, but attendance rates across racial groups are lower than enrollment rates, and there are high rates of grade repetition (Cardoso \& Verner, 2007; Ireland, 2007).

Translating these figures into literacy measurements, according to Ireland's (2007) analysis, there is a much higher concentration of illiterates in rural areas, with $26.3 \%$ versus $8.7 \%$ for urban areas. Illiteracy also affects minority racial groups more than it affects White Brazilians: $18.1 \%$ for Indigenous peoples, $16 \%$ for Blacks, and 7.1\% for Whites (Ireland, 2007). A person is considered literate in the above measures if they complete first grade. A person is not considered functionally literate, able to critical think through reading, until they finish fourth grade. Considering this, just over $76 \%$ of Brazilians over the age of 15 are functionally literate. However, in-depth analysis found that almost $60 \%$ of those who concluded fourth grade were not fluent readers (Ireland, 2007). Analyzing functional literacy rates according to race, Reiter (2009) reported that nationwide in $2000,36.1 \%$ of Blacks versus $20.8 \%$ of Whites were functionally illiterate.

\section{Challenges of Schools}

The problems that Brazil's public schools face are immense. School buildings are commonly in short supply, which leads to the school day being shortened to only four hours in many places in order to make three school shifts a day possible. This cuts back on the face time that teachers have with their students, gives teachers many more students, and contributes to high levels of teacher burnout (Gatti \& Barretto, 2009). Further organizational instability is fueled by public education officials being so closely 
tied to political parties. Reiter (2009) found that an estimated $20 \%$ of teachers employed in the public schools are "ghost teachers," those receiving teacher's salaries, but actually working elsewhere. For those teachers who show up to work, municipal and state schools are often designed so that they cannot compensate a teacher for performing well, and there are no possible sanctions if they perform badly (Reiter, 2009).

\section{Schools and Favelas}

According to Cardoso and Verner (2007), after the age of 16, there is an increasing percentage of those who drop out of school, but do not have a job. By the age of 18 , nearly half of teenagers are neither in school nor do they work (Cardoso \& Verner, 2007). Perlman (2010) made the point that considering that school is mandatory until the age of 14 , and legal employment and military service are only available to those over the age of 18 , this contributes to the gang participation of teenagers in Rio's favelas.

Analyzing the dropout rates of those 15 to 18 years old, Zaluar (1994) made a similar point that this is exactly the age that many male youth join organized crime networks. It seems that the laws passed to prevent the exploitation of child labor may have contributed to their increased participation in gang life and drug trafficking (Leeds, 2007; Perlman, 2010; Zaluar, 1994). This tendency is further complicated when gangs have a lot of interaction with the schools in favelas. Previous studies have found that Rio schools in and near favelas have increasingly become areas of contestation for gangs and drug trafficking (Abramovay \& Rua, 2002; Guimarães, 1998; Leeds, 2007; Zaluar, 1994).

There are endless examples of drug lords ordering students of Rio's favelas to stay away from school if there is an imminent threat from a rival faction. Traffickers make agreements to keep the police away from a school in exchange for a promise from 
the traffickers to not disrupt the school activities (Leeds, 2007). Schools located in and near favelas are also commonly subjected to theft: school equipment is damaged, snacks for the students are taken, and property is damaged (Guimarães, 1998). Drug traffickers have been known to pose as students and attend school in order to sell in the school, and recruit students to their gang (Abramovay \& Rua, 2002). The criminal networks that control the favelas of Rio essentially control any public institution in its geographic space. This includes schools, churches, and non-governmental organizations. Leeds (2007) suggested that if the school organization, culture, and curriculum addressed the social reality of the youth, the dropout rates and gang influence would likely be ameliorated. As is, the school culture and curriculum reflects the dominant culture. Consequently, the already marginalized favela population is pushed further into exclusion.

\section{Non-Formal Education}

Non-formal education (NFE) has been gaining speed and breadth in recent decades, often with marginalized populations or non-traditional students. Generally speaking, NFE focuses on citizenship development as its principle goal, promotes a flexible curriculum, and focuses on active student-centered learning with strong roots in the needs of the local community (Gohn, 1999). In developing countries, NFE programs are often run by non-governmental organizations, transnational agencies, and sometimes in cooperation with national and state governmental institutions (Farrell, 2008). It is through the coordination of such agencies that initiatives are underway throughout the developing world in order to reform educational systems which are currently doing little more than promoting the status quo of already marginalized populations. 
As traditional education has evolved, it has been linked with several core characteristics: (a) promoting the national standard curriculum, (b) working within the establishment of sanctioned institutions of learning, (c) collaborating with national systems of examination, (d) being compulsory for children and youth of a certain age, (e) focusing only on instruction, and (f) concentrating on teacher-centered instruction. In contrast, much of NFE operates in a more progressive framework: (a) applies a model independent of a top-down style of curriculum, (b) uses alternative and differentiated pedagogical methods, (c) focuses on the reality of its specific population, (d) operates on a voluntary basis, (e) focuses on instruction as well as socialization, and (f) promotes a participatory research-action model of learning (Gohn, 1999; Hoppers, 2006; Simson, Park, \& Fernandes, 2001a). Traditional education works to reproduce hierarchical social and cultural structures and favors individual competition, but NFE works toward solidarity and development of social change. Latin America in the 1960s was an early site for the development of NFE, aligned with the regional movement for Liberation Theology. Policy makers and development experts realized that traditional education addressed medium-term goals, and NFE could be used to address short-term goals for more rapid change (Hoppers, 2006).

\section{Non-Formal Education in Brazil}

Brazil was one of the initial sites for NFE in the 1960s as education activist and philosopher Paulo Freire worked to develop popular education and critical pedagogy. However, even through the 1980s, NFE was a small movement that was not given much attention by politicians or educators (Gohn, 1999). Zaluar (1994) found that in the 1980s, with a combination of a desperate economic situation, an increase in violent crimes, and a 
changing government, many NFE programs started emerging. They focused on sports, job training, and adult literacy. All was with the ultimate goal of increasing social and political participation. In the 1990s in Brazil, NFE came to focus on group learning and cultural values, and addressed an organizational culture that would necessitate extracurricular activities. The 2001 National Education Plan (PNE) broadened the definition of education in Brazil to allow for non-traditional literacy programs for youth and adults. Since this time, there have been an increased number of programs in Brazil that work with alternative schooling, life skills, community development, and vocational training (Ireland, 2007).

Gohn (2007) reported that a large portion of NFE programs in Brazil work with art education. The idea is that creating art is an important process of a person knowing and transforming his or her own world view (Gohn, 2007). Despite this effort, "it is important to note that there is no official coordinating body and no overall government policy for NFE" in Brazil (Ireland, 2007, p. 5). As a result, there is little consistency among the programs, no universal quality controls, or assessments to gauge how effectively the programs are meeting their goals, or even if the program has set any goals. This is problematic considering that NFE is part of a reform to address massive dropout rates and critical issues of quality education.

While there is no single monitoring agency where one can go to get a definitive answer for how widespread NFE is in Brazil, estimates are possible by looking at similar measures. Most large municipal governments in Brazil have a Municipal Council on the Rights of the Child and Adolescent (CMDCA), which are made up of members of civil society and the city government. The CMDCA in Rio de Janeiro keeps a register of the 
non-governmental and governmental programs that work with the city's children and youth. There are currently 428 non-governmental programs, 34 governmental programs, 246 programs that are associated with NGOs, and an additional 44 entities registered with the Rio CMDCA (Entidades Cadastradas, n.d.). On the lists from the Rio CMDCA, many of the NGO-run programs are residential associations of the favelas that organize activities for the children and youth. Others are large-scale programs that have attracted international attention. The lack of a regulatory agency explains the large number of programs that work with children and youth outside of formal education in city of Rio de Janeiro. Other research has found similar situations in other cities in Brazil (Gohn, 2007; Simson, Fernandes, \& Park, 2001a).

\section{Case Studies of Non-Formal Education in Brazil}

Education researchers have admitted that a breadth of literature on the cases of non-formal education in Brazil is still under development (Farrell, 2008; Gohn, 2007; Simson, Park, \& Fernandes, 2001b). However, with a total of 752 programs that work with children and youth in the city of Rio de Janeiro alone, a few of the educational youth programs in Rio de Janeiro and other parts of Brazil have attracted the attention of researchers, human rights activists, journalists, and documentary filmmakers.

Comparative case studies. Since 1997 the cultural sector of the Itaú Bank, Itaú Cultural, has run an annual competition called Rumos where intellectual and artistic creativity is showcased (Itaú Cultural, n.d.). The competition for 2005-06 focused on education, culture, and art. Educators across the nation were invited to participate with their students. Out of 200 educators who participated in Rumos 2005-06, the majority were from the Southeast of Brazil (half were from the city of São Paulo), were women, 
had completed high school, had experience working in formal education, and submitted projects in either visual or performing arts (Gohn, 2007). By analyzing the interpretation of the language used by the projects, Gohn (2007) focused on the importance of valuing cultural differences in education, on student empowerment through self expression and identity building, and on the importance of art to accomplish these goals. Gohn (2007) found that the projects used language that talked of being part of a larger social movement rooted in working with local communities and disenfranchised populations such as those who self-identified as being Afro-Brazilian, youth from low-income families, or victims of violence.

Alba Zaluar (1994) focused on the need to include the most impoverished of Brazil by guaranteeing the same civil rights as the rest of the population, and integrating them in the political and social workings of society. Drawing from extensive interviews, Zaluar (1994) evaluated several cases of NFE throughout Brazil on a number of issues. She found the programs in the study focused on the socialization process of the youth so that they would grow to be integrated members of society. Sport and play were recognized as important tools for building a self-identity and for youth to deal with daily stressors. Conflict between different social classes that participated in the programs was observed, but overall the programs promoted acceptance of all groups. Applying critical theory, Zaluar (1994) made an important contribution to the literature on NFE and situated her study in the intense socioeconomic divides of Brazil.

Single case studies. Grupo Cultural AfroReggae (GCAR) is arguably the most well-known youth organization in Brazil. The organization works in the areas of popular education and job training for Rio's favela youth, integrating the arts and Afro-Brazilian 
culture to empower its target population to work for social justice (Grupo Cultural AfroReggae, 2010). The thick description that Neate and Platt (2010) give of GCAR's history elucidates the critical situation in Rio's favelas. In a place where the most influential cultural attraction for many youth is the local faction, many of GCAR's leaders are former traffickers. This gives them the cultural knowhow and the street credibility to act as peace brokers for warring favelas and factions. Neate and Platt (2010) used a critical lens to view the social injustices and build a convincing argument for GCAR as an exceptional and successful case of youth development with an urban war-torn marginalized population.

Another unique initiative to work with some of the most disenfranchised youth of Rio de Janeiro, Projeto Uerê has a specialized curriculum to build the self-esteem, emotional capacity, and social skills of the children of the warring favela complex of Maré (Projeto Uerê, 2009). Treut (2001) showed squalid living conditions, abusive parents, lack of nutrition, and unusually high instances of H.I.V. for the most unfortunate of children and youth. Projeto Uerê's initiatives work with children and youth of all ages to build the self-confidence needed to confront infinitely difficult living conditions, and to train adolescents in technical skill that will generate income for the youth. The program also works with individual families and groups of children throughout greater Rio de Janeiro to provide scholarships to the Projeto Uerê school, and to provide a daycare center for children of homeless families (Truet, 2001). 


\section{Research Setting}

\section{Pereira da Silva}

Pereira da Silva is a rather small community (an estimated 6,000 residents) situated in the wealthy South Zone of Rio de Janeiro on a hillside that spans the uppermiddle class neighborhoods of Laranjeiras and Santa Teresa, and backs up to a government-protected nature preserve. A hotbed for drug trafficking in the 1980s and 1990s, Pereira da Silva was one of the first communities to undergo the favela-bairro model of integration, largely because of its close proximity to the governor's mansion, its small size, and the ease with which the only two entrances can be controlled (Rocha, 2009). During the initial stage of pacification, there was terrible violence in the community.

Rocha (2009) analyzed the memory of violence and the role that this time period played on the development of the identity of the residents of Pereira da Silva. She found that while today the community is considered to be pacified, the memory of violence and insecurity is still active in the behavior of the residents. Additionally, a profile of Pereira da Silva compared to its middle class neighbors shows that the residents are at a severe

societal disadvantage. Rocha (2009) reported that $81 \%$ of the residents are literate; $3 \%$ of the heads of households have completed 15 years of study; and 2\% earn 10 times the minimum wage. This compares with $94 \%$; $54 \%$; and $61 \%$ respectively for the middleclass neighborhood of Laranjeiras. The residents of Pereira da Silva have less formal education and consequently less earning potential than their middle class neighbors. 


\section{Projeto Morrinho}

Morrinho was begun in 1997 during the heightened levels of violence in Pereira da Silva. A group of local male youth, all relatives, friends, and neighbors, began constructing a scale model of Rio's favelas, and acting out with Lego characters the reality that they saw (Hafemeister, 2011). There was no formal input or organization of adults until 2001 when a teacher took interest in the reason why so many of the boys from Pereira da Silva were skipping school to participate at Morrinho. After several visits to witness the role-playing at Morrinho, this teacher introduced the boys to two of his friends, Fabio Gavião and Markão Oliveira, who were filmmakers interested in documenting the favelas of the city (Hafemeister, 2011). In return for the permission to document the play at Morrinho and life in the now pacified Pereira da Silva, Gavião and Oliveira taught the boys to shoot, edit, and produce film. The Morrinho group shot and produced on a professional level a number of film shorts set at the original model featuring the Lego characters that live at the model. Also, in 2002 the youth started building smaller-scale versions of the original model at the invitation of art and cultural institutions in Brazil and Europe. The culmination of the Morrinho Expos in this time period was a 650 square foot model at the 52 Venice Biennale in 2007.During this phase of development the Morrinho group also conducted workshops to teach youth of other communities how to build their own Morrinho model, and gave guided tours of the model to Brazilian and international tourists.

In September of 2008, under the direction of the Gavião and Oliveira, Morrinho released its feature length documentary at the Rio International Film Festival. Having formally incorporated Morrinho as an NGO in 2006, Gavião and Oliveira started the 
transfer of all administrative duties back to the boys, many of whom were now young adults. Since early 2009 Morrinho has operated on nearly and all volunteer basis, but has continued to work in Brazil and Europe, and has also worked in East Timor, Colombia, and the United States (personal communication). Morrinho's offices are no longer as busy as they had been from 2001 to 2008 , but one can rest assured that a few days a week at least a handful of local boys will be playing the game that was the original purpose of the Morrinho model.

God is not a snitch. Few doubt that the support that Gavião and Oliveira gave to the Morrinho participants was largely instrumental in the project's development to reaching a population outside of Pereira da Silva. The feature-length documentary film God Knows Everything But He's Not A Snitch ${ }^{2}$ is the joint product of the Morrinho youth telling their story and showcasing their incipient camera and production skills, and director Fabio Gavião and co-director Markão Oliveira using their professional skills to tell the story of their involvement with the Morrinho youth. God Knows Everything But He's Not A Snitch positioned Morrinho as a representation of the lived experiences of the participants at home and as they travel abroad. A source of some of the only footage of the early years of the Morrinho youth, God Knows Everything But He's Not A Snitch is one of the best comprehensive sources of information on Morrinho as an organization.

A favela different from others. Rocha (2009) described the model favelas at Morrinho as impressive due to the detail in representing Rio's different favelas, streets, and personalities. But she was also taken aback by the focus on the violence, drug trafficking, and that the activity seemed to be restricted to a closed group of participants.

${ }^{2}$ Deus sabe tudo mas não é X-9 
Rocha (2009) also had limited access to the youth and the filmmakers. Due to the Morrinho youth's reluctance to participate in extensive interviews, Rocha (2009) relied on the large number of film shorts on Morrinho's YouTube channel, the articles available on the Internet about the project's activities, visual images of the model, and observations of the interactions of the youth. Rocha (2009) developed a set of interpretations of Morrinho from her research.

First, if the creation of the project was a result of the youth rejecting violence, it did not make sense that Morrinho worked to keep the boys out of violence. They had already rejected such violence. Next, in contrast to the other residents of Pereira da Silva, the Morrinho youth do not silence the violence that they know. The focus of the violence in their play is a way of the youth molding their identity, and asserting that they are not victims oppressed by the violence and drug trafficking. Finally, the formal incorporation of Morrinho as an NGO set up the structure and organization that gave the youth increased freedom to discuss and mentally process the issues of drug trafficking and violence that is not available to the other residents of Pereira da Silva . Rocha (2009) was able to document some of the most in-depth activity of Morrinho that has not come in the form of film from the organization itself. Her analysis is valuable and insightful.

\section{Summary}

The literature related to the context of this study was reviewed in this chapter. Rio de Janeiro has the largest favela population in Brazil, and the residents face a number of sources of marginalization and oppression. Criminal networks, police abuse, and discrimination are factors that challenge favela residents (Arias \& Rodrigues, 2006; Neate \& Platt, 2010; Perlman, 2010). However, several researchers have also addressed 
how favelas are part of the fabric of Rio de Janeiro society (Goldstein, 2003; Neate \& Platt, 2010; Perlman, 2010). Cultural demonstrations of music and speech are ways that marginalized classes in Brazil have been able to build an identity and create a space of personhood (Roth-Gordon, 2009; Sneed, 2008; Yúdice, 2003).

Brazil's public school system faces many challenges including high rates of grade repetition, dropouts, and teacher burnout (Cardoso \& Verner 2007; Gatti \& Barretto, 2009; Ireland, 2009). As a result the public schools do little to shrink the achievement gap between the classes (Reiter, 2009). However, there is a large number of NFE programs that work with the children of Rio de Janeiro in the fields of art and culture in order to build a positive identity for the marginalized youth (Gohn, 1999; Entidades Cadastradas, n.d.). The goal of this study was to describe how the youth of one such program, the Morrinho organization, communicate their experiences of living in a favela. The following chapter discusses the visual critical ethnographic research method that was used to conduct this study. 


\section{CHAPTER III}

\section{METHODOLOGY}

This chapter begins with restating the purpose of this studying and the research question as were presented in Chapter 1. The framework for the research method of a visual critical ethnography is presented as it relates to the purpose of this study. This is followed by the procedure for the selection of participants and the participant profiles. The remainder of the chapter is designated to the data collection procedures, the data analysis, and integrity strategies that were used.

\section{Research Question}

The purpose of this visual critical ethnography was to examine the Morrinho participant experiences of living in a Rio de Janeiro favela. The main research question was

- What are the experiences of living in a Rio favela that the Morrinho participants communicate through their film, artwork, and words?

\section{Research Method}

A critical ethnography describes a culture through a conceptual lens that challenges entrenched power relations that keep many people oppressed (Rose, 2001). The purpose is to interpret new meaning of a culture for those outside of the cultural group and to work toward a positive societal change by linking what is being studied to a larger context (Carspecken, 1996; Pink, 2006). The traditional sources of data in a critical ethnography have relied on a researcher's first-hand observations of the activities and interactions of the population being studied. However, in recent years there has been stronger advocacy for the uses of visual media, film and photos, to act as representations 
of the culture in focus (Pink, 2007; Rose, 2001). This research study combined the traditional critical ethnographic design with a visual methodology.

As described by Carspecken (1996), a critical ethnography combines observations and interviews to arrive at different kinds of culturally bound truth claims: objective, subjective, and normative-evaluative. Objective truth claims refer to objects and events to "which all people have direct access" (Carspecken, 1996, p. 20). The term primary record is used to describe the record of objective truth claims before they are interpreted. Subjective truth claims refer to a person's state of mind and feelings to which only he or she has direct access, and can be inferred through facial expressions, body posture, and tone of voice. Normative-evaluative truth claims are "existing agreements to the rightness, goodness, and appropriateness of different types of activity" (Carspecken, 1996, p. 20). At the root of these three varied truth claims are theories about existence that make it possible to interpret different realities for different populations.

\section{Selection of Participants}

In my experience volunteering with the Morrinho organization in the years before my data collection, I had gotten to know 15 of the participants. I initially Facebook messaged these 15 participants to tell them of the purpose of my study and that I wanted to interview them. Those who did not respond to me via Facebook, I saw in person while living in Pereira da Silva, or I was able to text message or call. There was one founding member whom I had not met until I was ready to collect my data, but I was introduced to him through his family members and other Morrinho participants. I also asked each person whom I interviewed if they could think of anyone else who had been a Morrinho participant and should be in my study. This is how I met one of the younger participants. 
All of those whom I asked to participate in my study agreed, and in total I interviewed 17 Morrinho members. They were all long time participants of Morrinho, were all residents of Pereira da Silva, were between the ages of 15 and 29, were of varied racial identifications, and had completed varied levels of education.

Age

At the time of my interview with them, the eight participants who were considered original participants of Morrinho were all adults. Two were 29, three were 28 , two were 25 , and one was 23 . There were two participants who were not founding members of the project, but who appeared in the documentary toward the end. They were 23 and 24 years old at the time of the interview. Those who are considered the younger generation include one participant who was 20 , three who were 18 , and one who was 17 at the time of my interviews with them. The youngest participants were twins who were 15 years old.

\section{Race}

In order to be able to analyze any reference to race that the participants made in the interviewees, I asked them with what race they would identify. Of the 17 participants of this study, seven of them told me what race they are without hesitation and converse with me over the topic. Of these seven participants, six identified as being negro (Black), and one of them initially identified as preto (darker Black) and quickly changed to negro. Of the remaining 10 participants, one identified as being negro; one as preto; four as moreno (mixed-race); one as pardo (mixed-race); two as branco (white); and one as I don't know. All of the 10 participants who discussed with me at greater length what race 
is told me of the racial mixing that exists within their families, and for this reason they had to think about how they would describe themselves.

\section{Time Lived in Pereira da Silva}

Eleven of the 17 participants have lived in Pereira da Silva their entire lives. Maiquinho has spent nearly his entire life living there. He moved there full time by the age of five. Pedro is originally from Rocinha, one of the largest favelas in Brazil, and came to live full time in Pereira da Silva at the age of 7 or 8 . Gão moved to Pereira da Silva 10 years before the interview, when he was 13 . Luciano had moved to the community 14 years before the interview, when he was 11 . Nicolas had moved to the community 10 years earlier when he was 7 . Cilan was the oldest when at 14 he moved to Pereira da Silva.

\section{Time Participated with Morrinho}

All of the participants of this study started with the organization when they were in their early teenage years, and still participated in various ways at the time of the interviews. Eight of the participants responded that they had been with the organization for 15 years. These were the eight who considered original members and were primarily featured in the documentary film. However in their interviews, several of them admitted to not having participated consistently for all 15 years. Of the participants who were not in the film, two had been with the organization for 10 years; one for nine years; one for seven; one for six; and four for five.

\section{Education Level Completed}

Of the 17 participants interviewed, three of them had graduated from secondary education, all by an evening school equivalent program. At the time of the interviews, 
six of the participants were school-aged, but all slightly to very behind in their studies. One was in sixth grade; one in seventh; one in eighth; two in the first year of secondary school; and one was in the last year of secondary school. Of the eight participants who were over 18 at the time of the interviews, but had not graduated, five had stopped at the first year of secondary school. The others had stopped some time after the first year of secondary school.

\section{Data Collection Procedures}

The sources of data collected from the Morrinho organization were their documentary film, 206 documentary photographs that I took of the Morrinho artwork, and interviews with 17 of the Morrinho participants. My own researcher's observations of what it is like to live in the Pereira da Silva favela were recorded in the form of field notes.

\section{Documentary Film}

Documentary films are commonly rich in cultural information, compiled of both observations and interviews; often set in a larger sociocultural context; and have long been used to depict how marginalized populations live. A documentary film can be a rich source of data for a critical ethnography (Rose, 2001; Schere, 1995; Pink, 2007; Weakland, 1995). Morrinho's documentary film is a comprehensive source of information, because the film documents the youth communicating with each other about the Morrinho artwork at the headquarters in Rio de Janeiro; communicating with each other while building replica models in several European countries and in middle-class Rio de Janeiro and São Paulo; and explaining the artwork to people who are middle-class residents of Brazil and foreign countries. 
The first step of the data collection process was to transcribe the film, which I did by writing verbatim the English subtitles. I then built a thick set of notes on the shot presentation in terms of patterns, themes, and outlying information based on Metz's five channels of information of film: (a) the visual image, (b) print or other graphics, (c) speech, (d) music, and (e) environmental sound and sound effects (Monaco, 2000). I paid attention to the director's choices of content, shot composition, and how the shots were presented (Rose, 2001). A looser set of notes was kept on observations of character interaction (Carspecken, 1996).

\section{Artwork}

Data for the artwork was collected from 206 photos that I shot on manual setting with a digital SLR camera of the model favelas located in Pereira da Silva. The photos were both macro-level and wide-angle shots where I aimed to portray every angle and detail of the model. The manual setting was used to shoot photos of documentary style, so they were meant to not distort focus or colors (Bourdieu, 2003). I took intensive sets of notes on the visual materials. I looked for cultural symbols of music; choice of written words; and artistic style, including colors used and the positioning and representation of the objects used in the artwork. I then interviewed the participants about their interpretation of their artwork portrayed in the photos. In the interviews, I also asked all of the participants if they had any other photos that they would like for me to include in the analysis. Nicolas was the only participant who supplied me with additional photos. In the coming discussion, the photos that I took are referred to as solely numbers. The photos that Nicolas supplied me with are notated by an $N$ and a number. 


\section{Interviews}

A semi-structured format guided the interviews with the participants (See Appendix A; Wengraf, 2001). The guide was primarily comprised of open-ended questions where the participants were asked to describe (a) what a favela is and what it is like to live there; (b) what Morrinho is and what the artwork portrays; (c) what they think an outsider understands of living in a favela when they see the Morrinho model; (d) what they want an outsider to understand about what it is like living in a favela; and (e) how they think Morrinho represents what it is like to live in a favela in Rio de Janeiro. In the second part of the interview, I asked participants to view the 206 photos I had taken of their artwork and identify which photos they thought were the best representation of Morrinho, and say why (See Appendix C). Probing questions related to my own experiences of living in Pereira da Silva, my own understanding of what is communicated by Morrinho's film and artwork, and my familiarity with the reviewed literature. Each interview was conducted in Portuguese, took between one and two hours, and all but one was video recorded in order to capture the spoken words and vocal tone, hand gestures, posture, and facial expressions used to communicate a point. One participant did not wish to be videoed, so I took a more intensive set of notes on his non-verbal communication during and immediately after the interview.

\section{Field Notes}

I employed a participant-observer design of data collection by living and working alongside the participants of the study during the data collection process. This allowed me to document field notes on informal conversation and reflections on what life is like in Pereira da Silva. At the end of each day I reconstructed the events of the day, and each 
morning I reflected on interpretations of the events from the day before in the same journal (Wengraf, 2001).

\section{Data Analysis}

In the initial step of the analysis, the primary record was read several times, and initial coding was performed by taking notes of routine and unusual events (Carspecken, 1996). Next, several segments were selected to lay the foundation for initial meaning reconstruction. The goal was to articulate the meaning field, possible meanings, that the participants identified for themselves. Meaning fields were derived and reconstructive horizon analysis was performed based on a familiarity with the literature that was reviewed in Chapter 2, and by analyzing what was said or done in relation to the context (Carspecken, 1996).

The reconstructive horizon analysis included inducing objective, subjective, and normative-evaluative truth claims. Objective truth claims are those to which all people have access, subjective truth claims are the thoughts and emotions of the speaker, and normative-evaluative truth claims relate to societal agreements of what is right and acceptable. The process of deducing truth claims was performed in an iterative process. The foregrounded truth claims were the most closely related to the actual event, the backgrounded truth claims involved a higher level of analysis, and the highly backgrounded were the most remotely referenced (See Appendix D).

In the final step, theoretical applications were made along cultural constructions (Carspecken, 1996; Rose, 2001). Macrolevel analysis was performed by applying social theories to the reasons behind the unbalanced power relations. The entire analysis process was applied to the documentary film and the interviews with the 17 youth. The 
data of the artwork and the field notes were used to inform the analysis of the film and the interviews.

\section{Documentary Film}

In the analysis of the film, objective, subjective and normative evaluative truth claims were inferred from the dialogue and the primary record that had been on the auditory and visual images. This process of teasing truth claims out of the primary record was iterative, and was repeated five times. As the analysis progressed, each step of deducing truth claims was advanced by the integration with the other sources of data. The interpretation of the truth claims was made based on the literature reviewed in Chapter 2, and my experiences and reflections recorded in my field notes. I ultimately arrived at patterns in the data by reading through the lists of truth claims several times and taking note of routine and unusual events.

\section{Artwork}

The data recorded on the artwork was used to inform my analysis and interpretation of the interviews about the artwork. Objective, subjective, and normativeevaluative truth claims were deduced from the interviews about the photos of the artwork.

\section{Interviews}

I first had the interviews transcribed by Brazilian graduate students who were fluent in Portuguese and familiar with the context of my study. I then watched the video of the interviews to check the accuracy of the transcripts, took note of any change in the inflection of the participants' voices, checked the accuracy of the transcripts, and noted on the transcript where certain hand gestures and facial expressions were used to express a point. I analyzed the transcripts in Portuguese and took notes in both English and 
Portuguese, then noted truth claims. I read through the record of truth claims several times and made note of routine and unusual patterns. This process was repeated five times, each cycle of noting truth claims and patterns was elucidated by the integration of the other data sources.

\section{Field Notes}

After the film and the interviews were analyzed, the field notes were coded and paired with the analysis of the corresponding discussion in the interviews and the film. This information further shaped my interpretation of truth claims and the discussion in my analysis.

\section{Integration of Data}

The truth claims and possible meanings were compiled from the interviews and informed by the data of the field notes, the artwork, and the film. The patterns that emerged for most or all of the sources of data were related to the literature reviewed in Chapter 2. Finally, in Chapter 6 macro-level theories of habitus and critical pedagogy were applied to explain the reasons behind the unequal power relations experienced by the participants of this study.

\section{Integrity Strategies}

Integrity strategies are designed to enhance the trustworthiness of research. This is accomplished through enhancing credibility of the researcher's analysis and conclusions, and the transferability of the conclusions as valuable to audiences other than the participants of the research (Lincoln \& Guba, 1986). The credibility of this research was established in a number of different ways. A reflexive journal was kept throughout the research process with the goal of to enhancing my own consciousness to my 
perspective of truth claims, and my appreciation for the perspective of those whom I studied (Lincoln \& Guba, 1986). Triangulation of data and methods of analysis is a way of capturing and respecting multiple perspectives rather than seeking a single truth (Denzin, 2009; Lincoln \& Guba, 1986; Patton, 2002). The analysis of the four forms of data worked to enhance the credibility of my findings. Member checking is an additional way in which the findings of this study were enhanced. I asked the participants to confirm my interpretations of the data (Denzin, 2009; Merriam, 2002). The initial step was performed while I was on site in Rio de Janeiro. The second and final step of member checking was accomplished by emailing my final analysis to the participants and asking for their feedback (See Appendix E). In the initial stage of member checking the participants were able to clarify points, and in the final step those who responded supported my analysis. A clear and detailed audit trail enhanced the transferability of the findings by maintaining a clear and detailed audit that minimized bias and maximized accuracy (Patton, 2002). The multiple steps of making lists and descriptions of truth claims of each of the sources of data allow for an audit trail to be made. The data collection and analysis processes were checked by a team of outside reviewers who also acted as doctoral committee members for this dissertation (Patton, 2002).

\section{Summary}

The goal of this visual critical ethnography was to understand how the Morrinho participant experiences of living in a favela are communicated through their film, artwork, and words. The research method allowed an in-depth look while rooting the data and analysis in a framework of a rich context. I used four sources of data: Morrinho's documentary film, 206 photographs of the Morrinho artwork, interviews with 
the 17 Morrinho youth, and my own researcher field notes. The analysis of all sources of data entailed a multi-step process of identifying subjective, objective, and normativeevaluative truth claims. Critical social theory was applied, and the end result used macrolevel theory to understand the how the Morrinho participants implicitly and explicitly communicate their positions in society, and the perceptions of these societal positions. Several integrity strategies were employed to enhance the credibility and trustworthiness of this study. They include a reflexive journal, data triangulation, member checking, and an audit trail. This research has detailed the voice of marginalized residents of a Rio de Janeiro favela, and has contributed to the literature on non-formal education in Rio de Janeiro and Brazil. 


\section{CHAPTER IV}

\section{EXPERIENCES AS A FAVELA RESIDENT}

The experiences that the Morrinho participants have had living in Pereira da Silva were similar in many ways to the literature reviewed in Chapter 2, but their experiences also differed. As noted earlier, through a process of reconstructive horizon analysis, objective, subjective and normative evaluative truth claims were deduced. The objective claims that will be discussed are those to which all people have access. The subjective truth claims are the thoughts and feelings of a specific individual. The normativeevaluative claims relate to larger society, and to what is generally considered acceptable. The process of deducing truth claims was performed in a cyclical process. The foregrounded truth claims were the most readily available, the backgrounded truth claims involved a higher level of analysis, and the highly backgrounded involved the most advanced level of analysis and theoretical application. In the following discussion, those participants who addressed each truth claim are noted in parentheses. The ellipses included in some of the quotes indicate where I deleted part of what the participant said for the purpose of making his point more evident, and avoiding repetition of what had just been said.

This analysis resulted in truth claims that participants told of both negative and positive experiences. Within this discussion was a nuanced message that the participants are located within a larger societal framework as residents of a favela, but they also have unique individual experiences of living in Pereira da Silva. The issues that will be discussed in the following pages are (a) the societal exclusion and inclusion of the favelas; (b) societal placement communicated through semantics; (c) social markers of 
identity; (d) description of Pereira da Silva; (e) discriminatory experiences; and (f) school experiences.

\section{Placement in Society as a Favela Resident}

As residents of Pereira da Silva, the Morrinho participants are part of a marginalized population that they say has challenged them in certain respects. The challenges were lower levels of development in the community that they live in, and broken many promises by the government,. The very use of the word favela is something that the participants do not like, and for political, historical, and social reasons they all prefer to use the terms comunidade or morro to talk about where they live. A final description of societal placement as favela residents, the Morrinho participants identified clear social markers that are associated with a resident of a favela, but they also say these markers of individual identity are not always the same for each person.

\section{Exclusion and Inclusion of Favelas}

The social exclusion of favelas has been widely researched in the literature (Arias \& Rodrigues, 2006; Leeds, 2007; Neate \& Platt, 2010; Perlman, 2010). Similar to this literature, the participants feel as if they are part of a population that is both included in and excluded from the city. The Morrinho youth contrasted what a favela is like with what it is not, the asfalto. Participants also reflected on the social problem that Rio de Janeiro's favelas have historically been considered. Finally, they addressed the significant strides toward development that they have witnessed in recent years.

Economic, spatial, and security challenges. If favelas are housing settlements that grew outside of the incorporated grid of the city, the asfalto is what is legal and what is incorporated. In describing to me what they believed living in a favela is like, many of 
the participants contrasted such a life with what a life in the asfalto is like. Eight of the participants described favelas as being concentrated areas of housing for lower income people, and areas with little space in which to expand (i.e., Cilan, Luciano, Maiquinho, Pedro, Rafael, Rani).

Rani talked about life in the asfalto as being easier, principally because of access to shopping and entertainment. He also addressed the hardship of higher prices in Pereira da Silva that is associated with busses and cars not being available to the community. Rani then compared the higher prices of products within the favela to the much lower salaries that the community residents often earn, alluding to the deep socioeconomic division between the favela and the asfalto. As was addressed earlier, the ellipse in the following quote notates where words have been deleted so quote will not repeat what has already been said.

In the asfalto everything is easier, in the comunidade it's not. There are some things, for example the people that have a business here, like a bar, they have to go down to the asfalto and they have to come back up with the boxes of beer. So here it is getting expensive.... For example, the other day I went to buy macaroni to eat with my grandmother. I paid $\mathrm{R} \$ 1.50^{3}$ for each box of macaroni and in the asfalto it is 80 cents or 70 cents in the grocery store. And we earn less. The minimum wage is $\mathrm{R} \$ 600$. So you earn $\mathrm{R} \$ 4,600$ and to rent a house here in the

\footnotetext{
${ }^{3} \mathrm{R} \$ 1.50$ is equivalent to approximately $\$ 0.63 \mathrm{USD}$.
} 
comunidade for $\mathrm{R} \$ 400$. How is it that you are going to pay to eat with the bills you need to pay? It's difficult. ${ }^{4}$

Pedro also talked about the deep social divisions that exist between the favela and the asfalto. According to Pedro, the asfalto is where the cultured and educated people live; the people who are often the public officials, business managers, and those who work in the media. In a favela, Pedro told me that some people act in ways that are not permissible in the asfalto. It is common to see drug trafficking in a favela, and young men carrying large automatic weapons. However, he concluded the comparison by telling me that those who live in a favela do okay. There is a deep difference in the favela and the asfalto in that those in the favela live with drugs and violence, but he finds a positive compromise. Pedro has managed to find a way to deal with negative perceptions of where he lives.

The difference is that in the asfalto there are chic people and refined people. In a lot of the favelas there is drug trafficking and things like that. Not in the asfalto, you won't find drug trafficking or anything like that. In the favela you'll find all of this, people with guns. But it's okay, we get by. ${ }^{5}$

Rafael talked about the architectural and spatial differences of favelas and the asfalto. He perceived as a positive what may be the perceived negative of little privacy

\footnotetext{
4 "Lá embaixo eles tem mais vantagem em tudo, aqui na comunidade, não. Tem algumas coisas, por exemplo o pessoal que tem comércio aqui, barzinho, eles chegam lá embaixo e tem que subir com as caixas de cerveja. Então aqui está se tornando caro.... por exemplo, outro dia eu fui comprar um miojo para comer com a minha avó. Eu paguei $\mathrm{R} \$ 1,50$ em cada miojo, e lá embaixo é 80 centavos, 70 centavos, no supermercado. E a gente ganha menos, entendeu? Um salário mínimo é 600 reais. Aí você ganha 600 reais e um aluguel de uma casa aqui na comunidade é 400 . Como você vai pagar, comer, comprar, fora as contas que tem que pagar? É difícil."

5 "É que a diferença é que no asfalto tem gente chique e gente bacana. E em muitas favelas rola o tráfico de drogas e aquelas coisas. No asfalto não, você não acha tráfico de drogas e aquelas paradas assim. Na favela você acha isso tudo, gente armada. Mas tranquilo, dá para sobreviver."
} 
in a favela, because residents get to know their neighbors better, contributing to a community feeling that he believes is not easily achieved in the asfalto. According to a subjective truth claim analysis, a favela, or using the term that Rafael used, in a comunidade, people help each other out. Rafael prefers to live in a comunidade, because he values this community sense.

"On the asfalto the buildings and houses are surrounded by walls. Each is far apart from the other, or in the case of a building, there is may be two doors next to each other, but you never see your neighbors. It's either in the elevator or when you are in the entryway, you pass your neighbors. In the comunidade, no. You leave to go to the street and you see your neighbors. You open your door and sometimes you see your neighbors with their door facing you. You open it and you can already get to know your neighbors.",6

Social and economic constructions, as well as spatial issues, define what a favela is versus what the asfalto is (Perlman, 2010). Products are getting more expensive to buy in Pereira da Silva, drug trafficking is an omnipresent force in the favelas of Rio, and people in favelas tend to live close to each other in smaller spaces than in the asfalto (Arias \& Rodrigues, 2006; Neate \& Platt, 2010; Perlman, 2010). Participants of this study perceived these as negative aspects of living in a favela. Rani finished his statement to me saying how things were difficult in the favela; however, Pedro and Rafael communicated to me positives of living in such a community.

\footnotetext{
6 “Porque no asfalto os prédios e as casas são cercados de muros. Umas são distantes da outra, ou no caso do prédio é uma porta com a outra, mas você quase não vê seu vizinho. Ou no elevador, ou quando você está na portaria você passa e vê seus vizinhos. Na comunidade não, você sai na rua você vê seu vizinho. Você abriu a sua porta as vezes tem vizinhos com porta uma de frente para a outra. Você abre e já conhece o seu vizinho."
} 
The government perpetuates problems. Several of the participants of this study were highly critical of the government's treatment of the favelas (i.e., Criistian, Felipe, Gão, Maiquinho, Rodrigo). Felipe cited a number of problems that exist in favelas in general, and he linked the perpetuation of these problems to poor government response. As a result of this, the social problems in Rio de Janeiro's favelas have mushroomed. Felipe communicated in terms of normative-evaluative truth claims, today the social problems are too large to be fixed without large scale and comprehensive government intervention.

The favelas are a social problem because of what you find there. There are drugs, violence. So it's a problem that the government has to come in order to fix it. Because of this it's a social problem, because it involves the government, the city, this is why we can categorize it as social. So it's a problem because of this. It's not something that the comunidade can fix on its own. ${ }^{7}$

Gão spoke of the frustration of the promises of city political candidates. Here he talked about a visit to Morrinho by current Rio de Janeiro mayor Eduardo Paes. The visit created a lot of hope, only to later create disappointment. Gão explained that this is a common occurrence. Politicians regularly campaign in the favelas and make promises that they do not keep after the election.

Actually, he said that he was going to come here after he was elected and he was going to improve things. He was going to pay more attention to here. But

\footnotetext{
7 "Favela é um problema social por causa do que você encontra lá dentro, não é? Existem drogas, violência, entendeu? Então é um problema em que o governo tem que chegar junto para resolver. Por isso, é um problema social. Porque envolve governo, prefeitura, esse lado, aí já passa a se chamar de social. Aí, é um problema social por causa disso. Não é uma coisa que dá para se resolver dentro da própria comunidade, não dá."
} 
nothing. This was only a promise before he won. Nothing happened. This

happens a lot, every year. Every year that they run for election. ${ }^{8}$

Maiquinho also gave a macro-level criticism of the government's treatment of the

favelas. He expressed hope for Brazil because of the natural resources that the country

possesses, but he talked about a great injustice in relation to the government's treatment

of the favelas and the inconveniences and suffering that the residents feel.

When they started building the first shack made of stucco high on the hill, it was

the furthest distance from the city, like a favela. Why didn't the government do

anything? "I'll build a building, I'm going to give you an apartment, a house.'

After they built millions of houses on the hills, they say that it's an area of high

risk. Why didn't they come when they were being built? Are they blind? They

didn't see all of this happening? But why would they care? For nothing. It won't

make any difference for them. After there's a flood and 20 houses collapse, 30

people die, 20 families suffer with this, then they come and they write 'Restricted!

Prohibited to build a house here!' After the disaster happens? It's annoying. ${ }^{9}$

Rodrigo criticized the historic practices of the politicians and their complicity in

the cycle of violence in the city. He also elaborated on the societal repercussions of the

\footnotetext{
8 "Proposta, falou que ia vir aqui depois de eleito e ia melhorar e tal. Ia ter os olhos mais voltados para cá, não é? Mas nada. Isso foi só promessa antes dele se candidatar. Não aconteceu nada. Acontece muito, todo ano. Todo ano que os caras vão se candidatar."

9 "Quando começaram a colocar o primeiro barraco de estuque no alto de um morro, ou então em uma área mais destacada da cidade, tipo uma favela, por que o governo não fez o mesmo? Vou fazer um prédio, vou te dar um apartamento, uma casa, sabe? Depois que constroem um milhão de casas nas encostas, eles vêm dizer que são áreas de risco. Por que não vieram ver quando estavam construindo? Eles são cegos? Eles não viram isso? Eles viram isso tudo acontecer, sabe? Mas eles vão ligar? Para que? Para nada. Não vai fazer diferença nenhuma para eles. Depois que cai, que tem um enchente e vinte casas desabam, morrem 30 pessoas, 20 famílias sofrem com isso. Aí, eles vêm e escrevem: 'Interditado! Proibido construir.' Depois que acontece o desastre? É chato.”
} 
government neglect that Maiquinho described. To illustrate his point Rodrigo referenced the 2002 film City of God, directed by Fernando Meirelles and Kátia Lund. The film is based on is based on a novel of the same name by Paulo Lins, and is loosely based on real events that happened over decades of development in the Cidade de Deus favela.

I think that in reality it is a social problem, but this problem is caused by the government. "All that is bad, throw it in City of God," did you ever hear this phrase from the film? Oh, they don't have anywhere to live? Throw them in City of God. I think there was a time period a few years ago that the governor was trying to clean Rio de Janeiro, and all the bad stuff they found in the street they would put in the favela. This created a monster. This created upheaval. And this monster, he grew, and the comunidades started rejecting him. And what did the monster do? He went back to the asfalto.... Today, unfortunately, in Rio de Janeiro, if you go anywhere in the South Zone, you will find someone selling drugs, this isn't only in the favela anymore. Now it's all over Rio de Janeiro. ${ }^{10}$ In terms of subjective truth claims, Rodrigo feels disenfranchised from the government, because of the ineffective short-term solutions of the city and state governments. In normative-evaluative terms, the government does not act as a representative of all citizens and enforces policies that are detrimental to favelas, and ultimately to all of Rio

\footnotetext{
10 "Eu acho que é uma realidade que é um problema social, mas esse problema foi o governo mesmo que arrumou para eles, não é? 'O que é ruim, joga para a Cidade de Deus.' Já ouviu essa frase do filme? Ah, não tem onde morar? Joga, vai para a Cidade de Deus. Eu acho que teve uma época, há alguns anos atrás, em que o Governo estava querendo limpar o Rio de Janeiro, e tudo de ruim que eles achavam na rua, no asfalto, eles iam empreensando para a favela. E isso foi criando um monstro. Isso foi criando revolta. E esse monstro, ele cresceu, e aí a comunidade já não começou a dar vazão. E o que que o mostro fez? Retornou para o asfalto.... Hoje em dia, infelizmente, no Rio de Janeiro, se você for em qualquer bairro da Zona Sul, você encontra alguém vendendo droga, não está só mais no... não está só mais na favela, agora está no Rio de Janeiro inteiro."
} 
de Janerio. Rodrigo's words also reinforce the criticism in the review literature of

Brazil's division of persons, or gente, and individuals (DaMatta, 1995; Perlman, 2010).

Favelas are socially excluded. A few of the participants discussed how Rio's

favelas are excluded from societal participation and regular policing of criminal activity (i.e., Felipe, Paulo Vitor, Rafael). The increased marginalization of urban poor in Rio de Janeiro was the principal conclusion of Perlman (2006). Rafael described the difference in the levels of criminality that can be found in a favela and not in the asfalto.

The criminality of the comunidade, it is more associated with the comunidade than with the asfalto, with the upper class, a gated condominium. Because people who live in gated condominiums don't live amongst people who are armed, they don't live with drug trafficking or with prostitution. This is the social problem, the problem that we find in the favelas and what you can't find in the upper class. Because a lot of people live with this reality. And the people who live in the asfalto only experience this either when it's on TV, or when they are assaulted or kidnapped. In the comunidade we live that 24 hours a day. This is why it's a social problem. ${ }^{11}$

Paulo Vitor communicated in normative-evaluative terms, elaborating on the deep social divisions that exist within Rio de Janeiro, and the alienation of the city's favelas from

\footnotetext{
11 “A criminalidade da comunidade está mais associada na comunidade do que na rua, no bairro nobre, em um condomínio fechado. Porque as pessoas que moram em um condomínio fechado não têm a convivência com as pessoas armadas, não têm convivência com a droga ou com a prostituição naquele região. $O$ problema social seria isso, o problema que a gente encontra nas favelas e que a gente não encontra no bairro nobre. Porque muitas pessoas da favela vivem essa realidade. $\mathrm{E}$ as pessoas que moram em bairros nobres só vivem isso ou pela televisão, ou quando é assaltada, sequestrada. Na comunidade a pessoa está vivendo aquilo 24 horas por dia. Então é um problema social."
} 
general public dialogue. Paulo Vitor did not agree on this separation, nor does he agree on the generalization that favelas are centers for illegal behavior and violence.

The favelas are a bit excluded... because they are a bit isolated from everything. Everybody only talks about this place, and that place, but the favela, nobody talks about it. They only talk about it when something serious happens, when somebody does something. Then they send a helicopter to film, they do this then it makes the headlines. If not, no. ${ }^{12}$

The participants communicate that there is a cyclical cause and effect of the exclusion that the favelas and their residents face. The challenges of poverty, violence, and governmental policy contribute to society believing that favelas are centers of criminality. However, several participants pointed to evidence of progress toward inclusion.

The situation is changing. The participants widely commented on the social problems that exist in favelas, but widely rejected the idea that they are self-contained. Several of the participants talked about the government making advances to gradually improve the situation, however this talk of improvement was met with a critical eye (i.e., Betinho, Felipe, Junior, Nicolas, Rani, Renato, Rodrigo).

Two of the younger participants criticized the current situation. Nicolas talked about the common discrimination that favelas face and disagreement with the reason behind this criticism. He also talked about Police Pacification Unites (UPPs) that have been located in many favelas in order to aid the process of pacification and development.

\footnotetext{
12 "A favela ficar um pouco excluída... por ficar um pouco isolada de tudo. Todo mundo só fala daqui, dali e dali, mas da favela, ninguém fala. Só fala quando tem alguma coisa grave, quando alguém faz alguma coisa. Aí bota helicóptero para filmar, faz isso, aí vira manchete, se não, vai ficar lá. Raramente, vão chegar com alguma coisa, raramente. Ou, então, vai chegar com uma parte, aí vai sair uma parte para outra parte. Sempre assim.”
} 
Nicolas communicated that the improvements to the favelas and disappointment that improvements are not coming fast enough.

People are very prejudiced against the favela, I don't know why. People of society criticize favelas a lot, but now they are improving them, but still.... About a little over two years ago, three or four years ago people criticized a lot. When you would read, you would open the newspaper, they talked a lot about the favelas. Police dying, criminals dying. But now no, because the UPPs are coming in. But for me the UPPs haven't fixed anything. They are all very corrupt. ${ }^{13}$ Betinho also criticized the UPPs, their treatment of the residents of favelas, and the prejudice with which they treat people who enter the communities. In normativeevaluative terms, he spoke of the idea of the favela being a social problem, because that the general population largely misunderstands them.

Now it is full of police in the morros, but still there is violence. There's violence with the police, in the comunidades that have UPPs, there's a lot of violence. They beat up the residents. But nobody sees this side. They only see their side. Like, they come here now and they kill people, they're not going to say it was them. And they blame whom? The traffickers. ${ }^{14}$

\footnotetext{
13 “As pessoas tem muito preconceito com a favela, não sei por que. As pessoas assim da sociedade criticam muito a favela, agora não que deu uma manerada, mas mesmo assim.... Dois anos é pouco, faz uns 3,4 anos atrás as pessoas criticavam muito. Ah, criticavam. Porque assim, geralmente quando você lê, você abre o jornal, fala muito de favela. Polícia morrendo, bandido morrendo. Agora já não está porque entraram UPP, mas pra mim não adiantou nada a UPP. Eles são todos corruptos mesmo.”

14 “Agora está cheio de polícia nos morros aí, mas mesmo assim, está tendo violência ainda. Está tendo violência com as polícias, nas comunidades que tem a tal da UPP. Então, ainda está tendo violência, bastante violência ainda. Eles batem nos moradores. Mas ninguém vê esse lado, vê o lado só deles. Tipo assim, se eles chegarem aqui agora e matarem uma pessoa, não vão falar que foram eles. E vão botar a culpa em quem? Nos traficantes."
} 
A few of the older participants talked about how things used to be much worse. Junior talked about how things are getting much better due to the urbanization efforts that have taken place. Urbanization is seen as a positive move toward urban development and city planning that leads to better living conditions for favela residents.

A lot of things have changed, the way the comunidade is seen. Before, you would go into the comunidade and there wasn't urbanization, it was all clay, there was forest, everything was in poor shape. The government didn't pay attention, the city didn't come inside the comunidades. ${ }^{15}$

Renato talked about the UPPs which Betinho criticized. According to Renato, the UPPs are a good effort to rid the favelas of trafficking, and ultimately improve the quality of living for the residents. In subjective terms, Renato is troubled by the violence and trafficking in Pereira da Silva, and he thinks that the specialized police presence is helping the situation. In normative-evaluative terms, Renato's words praise the efforts that the government is currently making to pacify and integrate the favelas.

They are trying to generate more resources for the comunidade. One of the things is the UPP, that they are trying to put in the morro in order to be able to pacify, to be able to get rid of the trafficking. Getting rid of the trafficking, I think with this the conditions on the comunidade will start to get better. Because coming and going will be more free. With the trafficking, it is more difficult to come and go.

\footnotetext{
15 "Mudou muita coisa, o jeito que a comunidade é vista. Antigamente, você subia em uma comunidade, não tinha urbanização, era tudo de barro, tinha mato, tudo largado. O governo não olhava, a prefeitura não olhava para dentro das comunidades."
} 
So, society, the government, the state, they need to invest money in this. Before, they wouldn't even do this. Today they are investing more. ${ }^{16}$

The issue of the changing situation is also addressed in Morrinho's documentary film. God Knows Everything But He's Not A Snitch opened and closed with a song titled "I Am Favela,"17 originally performed and popularized by José Bezerra da Silva and redone by Leandro Sapucahy and Seu Jorge. The chorus of the song, "The favela is a social problem", ${ }^{18}$ as it is placed in the beginning of the documentary was overlapped with the instrumentals of funk music and set on a black screen. At the end of the film the viewer realizes that this audio on a black screen at the beginning of the film was a small part of the audio from Morrino's exhibit at the 2007 Venice Biennale. At the end of the documentary, a man who saw Morrinho in Venice sang the refrain into the camera as there was a split screen showing the play, the filming, and the interviews set at the location of the approximately 200 square meter model. This scene is set amongst others where Morrinho is being praised as a great work of art. In normative-evaluative terms, the viewer is asked to question what a favela is, a societal problem where marginalized people live, or a source of immense creativity, or both.

\footnotetext{
16 "Hoje em dia eles estão tentando fazer mais isso. Eles estão tentando correr atrás para gerar mais recurso para a comunidade. Uma das coisas é a UPP, que eles estão tentando colocar no morro, para poder pacificar, poder tirar o tráfico. Tirando o tráfico, eu acho que a condição de vida da comunidade já começa a melhorar. Porque o ir e vir da pessoa fica mais livre. Sendo que com o tráfico, o ir e vir da pessoa fica mais difícil. Então, a sociedade, o governo, o estado, eles tem que colocar dinheiro para isso. Antigamente, eles não estavam nem aí para isso. Hoje em dia que eles estão colocando mais."

17 "Eu sou favela"

${ }^{18}$ A favela é um problema social
} 


\section{Societal Placement Communicated through Semantics}

As noted previously, the terminology used to refer to Rio's marginalized communities expresses political weight, historical influence, and theoretical stances. There was a near universal rejection of the term favela, and a preference for the terms morro or comunidade. As the participants explained the choice of semantics depends on what subtle message one wants to communicate.

Favela is an ugly word. According to several of the participants, for those who know the cultural and linguistic nuances, favela is a pejorative term where poverty breeds (i.e., Gão, Luciano, Maiquinho, Nicolas, Pedro, Paulo Vitor, Rodrigo). Maiquinho emphasized the ugliness of the word favela, and his preferred usage of the word comunidade. In normative-evaluative terms, the discrimination that exists against the favelas is reinforced by the use of the very term. There are ways to promote social inclusion, and one of them is by sensitivity to word choice.

When someone says that you live in the comunidade, how do you see it? Like a morro, like a favela? It's an ugly name, for me to say 'I live in such and such favela.' And I say to you 'I live in such and such comunidade.' It's a nicer way of saying it. ${ }^{19}$

Paulo Vitor was more emphatic with his dislike of the word favela. He talked about the word's implications of poverty and as a basis for discrimination.

The worst is when they say favela, Favela Pereira da Silva. It's already seen with other eyes, because favela is more, favela is also a morro, like morro,

\footnotetext{
19 “Quando alguém diz para você que mora na comunidade, você enxerga como? Como um morro, como uma favela? É um nome feio, eu falar 'Eu moro na favela tal.' E eu falar para você 'Eu moro na comunidade tal', é um nome muito mais agradável, a forma de dizer."
} 
comunidade. "Such and such favela." It's that favela is already poor, they

already start to discriminate against someone without knowing. It's the worst. ${ }^{20}$

Gão described to me what came to mind when thinking of the word favela.

A favela is only alleyways, there are favelas that are only alleyways. One house next to another, sometimes, there are favelas where you walk by and the light of day doesn't get through... because there are the houses, there are a lot of houses. People build them one atop of another, houses on top of each other, and they end up being all together in one small place only wide enough for someone to enter. ${ }^{21}$ Gão typified the living conditions as a dark and cramped labyrinth and not as developed as other parts of the city.

The term morro differentiates from favela. In addition to the term favela being considered pejorative, all of the participants explained to me that they generally considered favelas where the land is flat, and a morro is a hill where there are stairs to get around (i.e., Betinho, Cilan, Junior, Maiquinho, Paulo Vitor, Pedro). Betinho explained to me what a morro, comunidade, and favela mean to him, but contrasted this with the terminology that he hears from the dominant voices in the media. "I think that morro is going up. Favela, I think that it's on the floor. Comunidade I think it means both

\footnotetext{
20 "Pior quando chama de favela, favela Pereira da Silva. Já olha com outros olhos, porque favela tem mais isso. Favela também é morro, quer dizer morro, comunidade. 'Favela tal.' Favela já é pobre, já é isso, já é aquilo, já começam a discriminar a pessoa, sem saber, não é? Pior ainda."

21 “Uma favela é só beco, tem favela que é só beco. Uma casa do lado da outra, às vezes, tem favela que você passa e não vê nem a luz da claridade... porque tem as casas. Há muita casa, aí o pessoal vai fazendo uma casa por cima da outra, casa por cima da outra, aí acaba que fica tudo junto e fica aquele espaçozinho só para você passar, entendeu?"
} 
things... In reality they never say morro, they only talk about favelas. " I asked "Who are they?" "Oh, the reporters, the people who talk, who only say favela.",22

Paulo Vitor further explained to me that Pereira da Silva is not a favela because it is not on flat land. We here on the morro think that a favela is flat. Since here is morro, a mountain, it was always like that. We always thought this way, that a favela is flat."23 Felipe addressed politicization of the terminology used to talk about the favelas. In normative-evaluative terms, over time what was called a morro or a favela underwent a development process and became to be known as a comunidade. Felipe communicated a level of development communicated in the previous section that the level of development and integration of the favelas has improved in recent decades.

Here they have called it a morro for years and years. Comunidade, they started to call it this after they started to pave the walkways and streets, they started to fix the walkways. After the residents association became something, a more communicative part of the comunidade, it came to be an organizing center. That's when they started to call it a comunidade, with the urbanization that they started. $^{24}$

\footnotetext{
22 "Acho que morro, assim, para cima, né? Favela, acho que é no chão, assim.. Comunidade acho que significa as duas coisas. Porque na realidade eles nunca falam morro. Falam só em favela." "Quem são eles?" "Ah, os repórteres, as pessoas que você fala, só falam favela."

23 “A gente aqui no morro acha que favela é mais plana, sabe? Como aqui é morro, montanha, sempre foi assim. A gente sempre pensou desse jeito, favela é mais plana."

24 “Aqui já chamam de morro há milhas e milhas de tempos atrás. Comunidade, começaram a chamar depois que começaram a fazer os pavimentos, começaram a endireitar os caminhos. Depois que a associação passou a ter uma parte mais, uma parte mais comunicativa com a comunidade, passou a ser um ponto de entrega. Aí começaram a querer chamar de comunidade, perante a urbanização que começou a ter."
} 
There is still developmental progress to be made, but Felipe believes that this could happen in the foreseeable future.

The term comunidade is more socially aware. There was division over the meaning behind the term comunidade. Some of the participants interpreted the term as a more socially and historically aware version of a morro or a favela (i.e., Cilan, Junior, Maiquinho, Rafael, Rani, Renato, Rodrigo). Agreeing with the use of the term, Rafael implied the community-like nature of living in a comunidade where neighbors help each other out in times of need. "We live in a comunidade, because we live together, with one another, houses close together. Because of this it's a comunidade."25 Junior told me that he thought the term comunidade emphasized a human aspect, and a rejection of the omnipresent influence of drug trafficking networks. "Comunidade you identify more with the residents. Comunidade has good people, who work, who study, who have their own interests. Morro is more associated with trafficking, more with violence. ${ }^{, 26}$ In normative-evaluative terms, Junior used the term comunidade as a reference to the integration efforts that the city is undertaking to incorporate the favelas. In subjective terms, Junior identified with the hardworking members of Pereira da Silva, and he believes that this is a demonstration of the positive aspects of where he lives.

Cilan explained his preference to using the term morro as a way of paying respect to the historic terminology of where he lives. "If I say that I live in the comunidade, I am

\footnotetext{
25 "Mas para quem vive aqui é comunidade, porque a gente vive junto, um com o outro, casa perto uma da outra. Por isso que é uma comunidade."

26 "Comunidade você identifica mais com os moradores. Comunidade que tem pessoas de bem, que trabalham, que estudam, que têm seus interesses. Morro fica mais para o lado do tráfico, mais para o lado da violência."
} 
expressing prejudice against the place that I live. Because where I live, what is the original name of where I live? Morro Pereira da Silva, it's not Comunidade Pereira da Silva... It's the history that it has."27 Rani further explained what may be person's aversion to using the term comunidade.

Other people say, when they are in a situation with important people, they say, “Oh, I live in the comunidade." But I don't think it's cool to say comunidade, because a lot of people talk about impoverished comunidades. The name comes from this. Everybody says, "Oh, let's help that kid who lives in the impoverished comunidade." They talk about this a lot. ${ }^{28}$

The participants of this study largely preferred to use the terms comunidade or morro to talk about where they live, and used the term favela to talk about where others lived. However, Rani explained in normative-evaluative terms that he does not like the term comunidade for where he lives because of the implications of poverty and neediness. Next I will address how Rani and other participants believe that all three terms are very related.

It's all the same. Several of the participants explained to me the emic and etic component of this discussion, that they saw the nuances in the three terms, but those who are from the asfalto, or the dominant culture, generally used the term favela (i.e., Budé, Criistian, Gão, Rafael, Rani, Rodrigo). Rodrigo explained to me that he sees the three

\footnotetext{
27 "Se eu falar que moro na comunidade, eu estou tendo preconceito do lugar onde eu moro. Porque o lugar onde eu moro, qual o nome original do lugar onde eu moro? Morro Pereira da Silva, não é Comunidade Pereira da Silva... É a história que ele tem.”

28 “Outras pessoas falam, que quando você está em um ambiente com pessoas mais importantes, você fala: Ah, eu moro na comunidade. Mas eu não acho muito legal falar comunidade, porque muita gente fala comunidade carente, entendeu? O nome da comunidade vem por causa disso. Todo mundo fala: Ah, vamos ajudar aquele garoto, que mora na comunidade carente, entendeu? Eles falam muito assim."
} 
terms as similar, but he emphasized the difference in the identity of the person. Rodrigo told me that whether a person considers himself from a favela, a morro, or a comunidade, he can tell who is not from the asfalto and who is. In normative-evaluative terms, Rodrigo believes there should be a stronger push toward equality in society, because he believes that people are basically the same.

I don't see a lot of difference. It's very complicated when you talk about the difference between comunidade, morro, and favela, because I know that each morro is a morro, each favela is a favela. Sometimes you see differences when you enter a favela, but talking about the people, I think it's all the same thing. ${ }^{29}$ Rani voiced a similar opinion. Rani communicated that the three terms mean the same thing, but they have different political weight. "Favela, morro, and comunidade, all mean the same thing. There are different and more polite ways of speaking. But it's all the same thing." 30 Nearly one third of the participants of this study explained that the three terms basically mean the same thing. However, there nuanced meanings of terms favela, morro, and comunidade will be further explored in Chapter 6.

\section{Social Markers of Identity}

In my reading of the literature (see Goldstein, 2003; Perlman, 2010), and my previous experiences living in Pereira da Silva and volunteering with Morrinho, I came to understand that there is a difference in social markers of who lives in a favela and who

\footnotetext{
29 “Eu não vejo muita diferença. É que é muito complicado quando você fala da diferença entre comunidade, morro e favela, porque eu sei que cada morro é um morro, cada favela é uma favela, as vezes você vê aqui um costume que quando você entra em outra favela você vê que é diferente, mas em questão de pessoas, eu acho que é tudo a mesma coisa."

30 "Favela, morro e comunidade, querem dizer a mesma coisa. Sendo que tem as maneiras de falar mais educadas, entendeu? Mas é tudo a mesma coisa."
} 
lives in the asfalto. It is these social markers that could be the basis of stigmatization and discrimination. Before discussing discrimination, I wanted to understand what these social markers would be. Agreeing with Bourdieu's (1977) discussion of habitus, many of the participants were able to identify distinct speech patterns, style of clothing, and preferred genre of music.

Speech patterns. Several participants talked to me about choice of words and speech patterns being different amongst those who live in a favela and those who live in the asfalto (i.e., Betinho, Criistian, Paulo Vitor, Rani, Rodrigo). These participants said that a general principal difference in how they talk is that slang is more prevalent in the speech of those from a favela. Betinho told me, "I think they talk differently than how we talk, because here we speak with slang. And they don't speak with slang, they speak normal." ${ }^{31}$ Paulo Vitor elaborated on the types of slang used. He described the finding in the literature researched, that people from the asfalto come to adopt the expressions that originate in the favelas (Roth-Gordon, 2009). In normative-evaluative terms, Paulo Vitor communicated that it is possible to tell what social class a person belongs to by the way that he or she speaks, but the media plays an important role in the larger social acceptance of the terms that originate from the favelas. "The slang that we use 'cool', 'chill', 'this thing'. People who live on the asfalto rarely speak it. They only say it when it's used in a soap opera on TV., 32

\footnotetext{
31 "E falam... Acho que eles falam diferente do que a gente fala, porque aqui a gente fala com gírias, né. E eles não falam com gírias, eles falam normal."

32 "As gírias que a gente usa maneiro, está tranquilo, essa parada. Gente que mora na rua raramente fala. Só falam quando passa na novela, quando passa na televisão."
} 
Rani further explained what happens with the use of slang. Nicknames are also often common in favelas. Whereas people from the asfalto may have a nickname that sounds like their given name, many nicknames of people from the favela are, as Rani says, invented.

We have our own language that we end up inventing, we invent it and when we speak it in the asfalto, they don't understand.... Nicknames too. The majority of the people have nicknames. Sometimes you've known the guy for five years, but you don't know his name, you just know his nickname. In the asfalto, they have nicknames too, but I generally don't hear this. A lot of time the nickname of people on the asfalto is an abbreviation of their name. Daniela is called Dani. Rafaela, Rafa. Always abbreviating. Here we don't, we invent something. ${ }^{33}$ All of the participants told me that not everybody from the favelas, uses slang, and that some people from the asfalto use slang terms. But generally speaking, the slang originates from the favelas.

Style of clothing. Several participants talked about a certain style of clothing that is marked as being the type that someone from a favela would use (i.e., Betinho, Criistian, Maiquinho, Nicolas, Paulo Vitor, Rafael, Rani). Betinho explained to me that people from the asfalto generally wear name brand clothing and look more put together than people from the favela. This is in part due to the available income that the people

\footnotetext{
33 “A gente tem uma própria linguagem que a gente acaba inventando... A gente inventa, e quando a gente fala na rua, eles não entendem... apelido também. A maioria das pessoas se conhece mais com o apelido, ás vezes você conhece o cara há 5 anos, mas você não sabe o nome dele. Você só conhece ele pelo apelido, entendeu? Ah, lá embaixo eles também tem, mas geralmente eu não vejo uma pessoa chamando a outra pelo apelido. Muitas vezes, o apelido deles lá embaixo é a abreviação do nome, entendeu? Daniela, chamam ela de Dani, entendeu? Como Rafael, Rafa. Sempre abreviando. A gente aqui, não. A gente aqui inventa alguma coisa."
} 
from the asfalto have that those from a favela do not. "They get more dressed up... like with clothing that we don't have, more expensive clothing. Athletic shoes, brand name athletic shoes." ${ }^{, 34}$ Rani also spoke to me about the difference in clothing between the asfalto and the favela and cited the price difference in the brands of clothing that each class wore. Rani commented that the clothing that the people from the asfalto wear are more expensive, but it doesn't always look that expensive. In normative-evaluative terms, Rani communicated that the differences in the way people dress are demonstrative of a person's social class and wealth.

Here in the comunidade we wear a more comfortable style of clothing - sandals, shorts, a baseball cap, always a baseball cap. On the asfalto, no. It's their own style of clothing. Their clothing, a lot of people wear clothes that are more expensive, but simpler. ${ }^{35}$

Criistian and Nicholas both elaborated on the differentiation that Betinho and Rani made. They explained that name brands are often something that can mark a person as being from the asfalto or being from the favela. There is a type of shoes that are commonly known for people in a favela. Speaking of people from the asfalto, Criistian told me, "They like normal sandals. People from the asfalto wear Havaianas. In the favelas they are more, they wear more Kenners. "36 Nicolas said, "There is a kind of

\footnotetext{
34 “Andam mais arrumados... tipo assim, com roupa que a gente não tem, roupa mais cara. Tênis, tênis de marca."

35 "A gente aqui na comunidade gosta muito de andar mais a vontade, chinelo, bermuda, boné. Sempre de boné. Na rua, não. O estilo de roupa mesmo deles. As roupas deles, tem muitos que tem roupas mais caras e mais simples, entendeu?"

36 "Eles gostam de, tipo assim, chinelo normal. O pessoal do asfalto usa havaiana. Na favela, eles são mais, eles usam mais Kenner."
} 
sandal called Kenner... and who wears it a lot are people from the comunidade. So you see that person and say 'hmmm, he's from a comunidade.' The way of dressing is a way to tell. ${ }^{37}$ This discussion of style of clothing will be further addressed in a later section when I address how Nicolas linked how someone dresses to the level of discrimination that they may experience while in the asfalto.

When talking of clothing style, acknowledged that favelas residents are known to dress in a way that differs from the dominant society. But emphasized that mothers teach their children in the favela like they would in the asfalto. According to Rafael, it is the socialization and learned behaviors that develop in both places that lead to the difference in clothing in the youth. Beneath Rafael's words are a message that those from the favela are not that different from those from the asfalto.

There are women in the comunidade that like to wear short skirts, and a top to go anywhere. The girls from the asfalto wear other things, like a dress, pants. It's the style of the person, how each of their mothers educates them. But there are people that because of who they hang out with, forget what they learned in the comunidade, what their mother taught them. ${ }^{38}$

Seven of the participants of this study talked to me about the different style of clothing that residents of the favela and the asfalto wear. They communicated that there are tastes that are acquired through socialization and as a result of financial resources.

\footnotetext{
37 "É porque tem um chinelo que se chama Kenner... e quem usa muito a gente diz que é de comunidade. Então a pessoa olha e diz 'hum, é de comunidade.' O modo de se vestir já da para ver, está entendendo?”

38 “Tem mulheres da comunidade que gostam de usar sainha curtinha, top, para andar em qualquer lugar. As meninas do asfalto usam outras coisas, como vestido, calça. É o jeito das pessoas, como a mãe educa cada uma dessas pessoas. Mas tem gente que pelo convívio com outras pessoas esquecem o ensinamento que tiveram na comunidade, que a mãe passa na comunidade."
} 
Style of music. The literature talked about hip hop and funk music being the most prominent in the lower class urban center of Brazil. But where hip hop is the music most popular in the favelas of São Paulo, funk is the music that evolved in the favelas in Rio de Janeiro (Neate \& Platt, 2010; Sneed, 2008; Pardue, 2008; Yúdice, 2003). A few of the participants characterized the music popular with favela youth as being hip hop and funk (i.e., Gão, Maiquinho, Rafael). Maiquinho, a funk emcee and Rafael discussed this point. In normative-evaluative terms, music can be a demonstration of a person's identity, but that identity is moldable. Maiquinho communicated that it is possible for people to have similar taste in music despite different socioeconomic backgrounds. "Things from funk, from hip hop. Not that people from the asfalto don't listen to these types of music, but the comunidade has it." ${ }^{, 39}$

Rafael talked more specifically about the type of funk music that can be found in the favelas. Rafael reinforced what Neate and Platt (2010), Sneed (2008), and Yúdice (2003) explained, funk music from the favelas is often associated with violence and trafficking. The [funk] dances a lot of times in the comunidade is liberado. What is liberado? Proibidão? You sing what you live, what you want, what comes into your head. On the asfalto, no. If I am an emcee and I come to sing in the morro, I can sing without making apologies, say a lot of things. On the asfalto, no. You have to make the music more receptive to the people. Make it in a way that they will understand what you want to say without cursing. ${ }^{40}$

\footnotetext{
39 “Coisas mais do funk, do hip hop. Não que as pessoas do asfalto também não possuam esses tipos de itens, mas a comunidade leva."

40 "'O baile é muitas vezes na comunidade liberado. Liberado é o que? O proibidão? Você canta o que você vive, o que você quer, o que vem na sua cabeça. Já na rua, no asfalto não. Se eu sou um MC e eu venho
} 
Music commonly addressed in the literature as a cultural marker, and as a demonstration of taste and class. However, only three participants talked to me about music being a signal for a person who lives in a favela.

Social markers aren't always well defined. Over the course of my conversations with them, many of the participants rejected at one point or another any typification of what someone who lives in a favela is like (i.e., Cilan, Junior, Maiquinho). Cilan emphasized that it is difficult to identify who lives in a favela based on appearance because of the diversity that exists. In normative-evaluative terms, Cilan communicated that education and culture can be a dividing factor in society, but that the clothing that someone wears is not always demonstrative of that division. "It's kind of difficult to identify who lives in a favela and who doesn't. I can very easily dress like an executive and be in a favela. I can live in a favela, but dress like a businessman and people will look at me like a businessman." ${ }^{41}$

Junior talked to me about how the typical styles of clothing of the favela and the asfalto are switching. He told me that many youth from the asfalto dress in clothing that will identify them as being from a favela, and those from a favela aim to dress like they are from the asfalto so they will avoid discrimination. First speaking of those from the asfalto Junior said,

\footnotetext{
cantar no morro, eu posso cantar, fazer apologia, falar muitas coisas. No asfalto já não, você tem que falar, fazer uma música mais receptiva para as pessoas. De um modo que as pessoas entendam o que você quer falar sem falar o palavrão."

41 “É meio difícil identificar quem é da favela e quem não é da favela. Eu posso muito bem me vestir como um executivo e estar dentro da favela. Posso morar dentro da favela, mas me vestir como um empresário e as pessoas vão me olhar como um empresário."
} 
"Not everybody, but the majority like to go to the comunidade, for example, and go to funk dances, they like to behave like people from the comunidade, relaxed, Bermuda shorts, any type of t-shirt, with sandals. People from the morro, no.

They like to use nice athletic shoes, wear nice clothes so they won't be discriminated against." ${ }^{, 42}$

Maiquinho elaborated on the above point that Junior and Cilan made. Sometimes you can tell who lives in a favela based on what they look like or how they act, but sometimes you cannot.

"Rich people don't pay attention to show off what they have. A poor person has to show the little that he has, he tries to show it in a chain, a gold ring. The little that he has, he wants to show it to others, what he was able to get in life. A rich person doesn't have this problem. He wears Havaianas, which cost five reais, but he's got $\mathrm{R} \$ 50,000,000$ in his bank account. He doesn't care if he walks barefoot on the beach or if he's barefoot in the market, if he's in his bathing suit. He doesn't care. His bank account is full. Us no. We are poor, if we dress like a beggar, everything gets worse." ${ }^{, 43}$

\footnotetext{
42 "Nem todos, mas a maioria assim que gosta de ir em comunidade, por exemplo, de ir para baile funk, eles já gostam de se comportar como as pessoas da comunidade, relaxado, bermudão, qualquer camisa, de chinelo. As pessoas do morro não, já gostam de andar de tênis bonitos, roupa bem vista, para não rolar discriminação."

43 “O rico não liga muito para ostentar, para mostrar o que ele tem. O pobre tem que mostrar o pouco que ele tem, ele tenta mostrar no cordão, no anel de ouro. O pouco que ele tem, ele quer mostrar para os outros, o que tem, o que conseguiu na vida. Já o rico não tem problema. Ele está andando com uma Havaiana no pé, que é cinco reais, mas ele está com uma conta de 50 milhões de reais. Ele não está ligando se está descalço na praia, se está descalço no mercado, se ele está de sunga. Ele não liga. Ele está com a conta cheia de dinheiro. A gente, não; a gente é pobre, se a gente andar igual a um mendigo, aí piora tudo, não é?"
} 
This section also addressed a number of contradictions about societal placement as residents of a favela. They are marginalized and oppressed in a number of ways, however favela residents are very much a part of society and the level of integration is improving over time. There are ways to signal a point of view by using the terms favela, morro, or comunidade. But there is also discussion that the three terms basically mean the same thing. Style of clothing, music, and speech can have a lot to do with how a person identifies. However, due to the diversity that exists within favelas and the variety of personal identities that this diversity includes, there is not always one favela style.

\section{Individual Experiences of Living in a Favela}

In the above discussion, the participants discussed their thoughts on being residents of a Rio de Janeiro favela, but they also have their unique individual experiences of living specifically in Pereira da Silva, their own experiences with discrimination, and their own experiences with the educational system. While Pereira da Silva has experienced heightened levels of violence and drug trafficking, and is a concentration of poverty, all of the participants say there are benefits of living there. The participants all talked about types of discrimination that they witness, but a few talked about efforts they go to in order to avoid discrimination. Finally, the participants talked to me about their experiences with the educational system. Although some of the experiences could have been better, there were not the extreme stories of violence in schools that were addressed in the literature (Abramovay \& Rua, 2002; Guimarães, 1998). 


\section{Description of Pereira da Silva}

Over the course of my work and research with Morrinho, in 2009, 2010, and 2012, I have a total of four and a half months working in Pereira da Silva. And in the last two years I rented an apartment in the community. It is not a place that I ever felt threatened, and it is a place where I always felt welcomed by my neighbors and the community leaders. My second week working with Morrinho in 2009, it was getting late and I asked Cilan if it would be okay for me to walk back by myself. Without thinking twice he said that in the community I would be fine, it was outside where I would have to worry. I initially took this comment lightly, but in retrospect, it is illustrative of divisions in security and identity, that the participants talked about in their interviews. As I researched the security threats and violence of the majority of Rio's favelas, I came to think that Pereira da Silva may be an anomaly of a community.

Calm environment. The calmness of the community was one of the most commonly cited advantages of Pereira da Silva (i.e., Betinho, Gão, Junior, Luciano, Nicolas, Rafael, Rodrigo, Teibe), and was a central point of interest for Rocha (2009). Nicolas described Pereira da Silva's peacefulness in a way that I have commonly heard other residents speak. He did not describe trafficking and violence, but a place that is closely linked with its natural surroundings. In normative-evaluative terms, Nicolas communicated that there should be more value placed on the real estate in Pereira da Silva, because in his experience there are real benefits to the calm environment. Nicolas also talked about the spectacular view from Pereira da Silva of a popular tourist destination, the Sugar Loaf mountain located at the mouth of the Guanabara Bay. 
The advantage of living in a comunidade is that when you wake up in the morning you don't see, you don't have that noise from the street, the horns honking. It's calmer, relaxed. It faces the sun, you can see the sunrise, and Pereira even faces Sugar Loaf. So, when it's like this in the summer, you see the sun rising and setting. So I think it's calm. If you live in the asfalto you don't get this benefit, you just get in your elevator and you are on the street. ${ }^{44}$

Pereira da Silva is a small community in which there are few shops and restaurants among the houses, which are connected either by narrow paths or staircases. There are no streets wide enough for cars to enter the community. As Rafael pointed out, this leads to a calmer atmosphere.

There's not a lot of confusion. It's a small comunidade. In larger comunidades there is a bit of chaos. A lot of people running here and there, a lot of noise. Here it's calmer, there some people that may shout, make a bit of a mess, but that is temporary. ${ }^{45}$

A few of the other participants discussed the drug trafficking that exists in Pereira da Silva, but they ultimately described this as limited compared to many other Rio favelas. Luciano describe what the day to day life might be like for someone who lives in a favela as one full of fear of the violence that may break out amongst the police and the

\footnotetext{
44 "A vantagem de morar na comunidade é que você quando acorda de manhã você não vê... Você não tem assim aquele barulho de trânsito. Buzina "Fon". Aqui é mais tranquilo, relaxado. De frente para o sol, você vê o sol ascendo. Então vê assim, ainda mais aqui na Pereira que bate de frente com o Pão-de-Açúcar. Então quando está assim no verão, você vê o sol nascendo e indo embora. Então eu vejo que assim, é tranquilo. E morar no asfalto você não precisa desse humor todo, é só você descer o elevador que você está no asfalto.

45 "Não tem muita confusão. É uma comunidade pequena. Em outras comunidades maiores a gente vê que tem um pouquinho do caos. Muitas gente correndo para lá e pra cá, muito barulho. Aqui é mais tranquilo, tem um ou outro que grita, zoa, mas é temporário.”
} 
traffickers. He then contrasted this with the peacefulness that exists for residents of Pereira da Silva.

The day to day of living in a comunidade is people wake up very early to go to work and they descend scared [to the asfalto]. A lot of times they are scared that they won't be able to go back up the comunidade when they return. This is in normal comunidades, not here. The morro is calm, you can come and go at any time. $^{46}$

Rodrigo explained that Pereira da Silva use to be a more violent community, but it is much more pacified today. Rodrigo communicated that there is still trafficking and occasional shootouts. However, the violence is rare and the trafficking does not inhibit or control the movement or the actions of any of the Pereira da Silva residents.

Pereira to live in today is marvelous. There is trafficking, like there is anyplace, here it's not different. But it's not armed trafficking that's oppressive. There are no gunshots, no shootouts. So it's very calm here, it doesn't depend where you live, you see? I can enter here calmly, the residents can enter calmly, without being scared of repression, no matter where they are. Here it's calm, more so than in other comunidades. ${ }^{47}$

Eight of the participants described the calmness of the Pereira da Silva as a positive. This is also something that I personally experienced when I was living there. In

\footnotetext{
46 "O dia a dia da comunidade é as pessoas de bem acordam cedo para ir trabalhar e já descem com medo de. Muitas vezes, descem com medo quando voltar não poder nem subir na comunidade. Isso aqui nas comunidades normais, não aqui. O morro é tranquilo, você pode subir e descer a qualquer hora."

47 "A Pereira pra morar hoje em dia é maravilhosa." Tem tráfico, tem em qualquer lugar, aqui não é diferente. Mas não é aquele tráfico armado, que é pesado. Então não tem tiros, não tem troca de tiros. Então isso é muito tranquilo, independente de moradia, Entendeu?" "Eu subo aqui tranquilo, os moradores podem subir tranquilos, sem medo de represaria, independente de um lado ou de outro. Aqui é tranquilo sobre isso como em outras comunidades não é."
} 
my experience of living in Pereira da Silva for three months, I would commonly wake up to the sound of birds chirping and I would go to sleep to the sound of silence. During the day Pereira da Silva was an escape from the busy city's traffic sounds. In addition to this calmness, several participants also addressed the community feeling in Pereira da Silva as an added value.

Community feeling. A community feeling was a commonly cited benefit of living in Pereira da Silva (i.e., Betinho, Junior, Luciano, Maiquinho, Nicolas, Paulo Vitor, Pedro). This too is something that I witnessed in the months that I lived there. Though I was not a long-term resident, it was not common for me to eat a meal by myself, because there was usually someone who was willing to join me. Polite exchanges in small talk either with the community's children or adults was the most common reason for me to be late for an appointment.

Luciano explained that the positives of living in Pereira da Silva generally outweighed the negatives. Among the benefits of the community is the network of friends that he has there.

A friendly environment, a lot of friends. A lot of friends. I could have left here, but I like it here.... I like my comunidade a lot.... We are more about getting to know each other, about friendship. There outside, people are more closed, they don't have this set up of a comunidade, it's every man for himself and that's it. Here, no. When you have a problem, your friend knows, your friend comes here and helps you and everything. ${ }^{48}$

\footnotetext{
48 "Um ambiente agradável, muitos amigos, não é? Muitos amigos. Eu até poderia ter saído daqui já, mas
} eu gosto daqui... Gosto muito da minha comunidade.... Nós temos mais convivência, mas amizade. E aí 
Paulo Vitor talked about an advantage of Pereira da Silva being the network of family that he has that lives close. The emphasis that he puts on having his family close is a large reason why he prefers to live in Pereira da Silva than anywhere else.

For me, I have lived here forever, it's calm. My whole family, my whole family no, almost everybody. Family on the other side, I've got family up above, my grandmother lives there close to the house where I used to live. Now, my entire family lives here, a ton of cousins, aunts, uncles.... Having family close, friends close, friends from childhood, everybody close to each other. Someone leaves and then comes back. You leave, you travel, but you come back. It's always everybody close, friendship continues very strong. ${ }^{49}$

Pedro went beyond talking about the network of his family that lives in Pereira da Silva, and compares the community to a mother. He said that it is a comforting place to live where people support each other. In subjective terms, Pedro values the network of people that he can trust in Pereira da Silva. Their support has aided him in developing a positive self-identity. In normative-evaluative terms, Pedro said that certain favelas can be supportive places to raise children and guide adolescents.

Where everybody knows each other, where everybody talks to each other, not everybody. Not everybody likes each other, but it's a good group, it's cool, we have fun, we play. This comunidade is a mother. It's a mother because, if you

\footnotetext{
fora, as pessoas são muito fechadas, não tem esse conjunto de comunidade, cada um por si e pronto. Aqui, não, quando você tem um problema, seu amigo sabe, seu amigo vem aqui e te ajuda e tal."

49 “Olha, para mim, que moro aqui desde sempre, é tranquilo. Minha família inteira, família inteira não, Quase todo mundo. Família do outro lado, família lá em cima, minha vó vive ali perto da casa onde eu morava antes. Agora, minha família inteira mora aqui, primos para caramba, tio, tia.... Ter a família perto, os amigos perto, amigos de infância, todo mundo, um perto do outro. Vai sair um, aí volta. Vai sair, vai viajar, mas volta. Está sempre todo mundo perto, a amizade continua muito forte."
} 
arrive, how can I say that this here is a mother? Here you will always be well received by others. If you need, everybody will give you motherly advice, will say 'look don't do this because of this and this.' So this morro is a mother. ${ }^{50}$

The strong community feeling of Pereira da Silva is also displayed in God Knows Everything But He's Not A Snitch. After the group of the original participants of Morrinho traveled to Spain, their first trip abroad, there is an emotional welcoming scene. There was a group of their friends and family waiting in a plaza just before the street that leads to Pereira da Silva. As they saw Cilan waiving his hands out of the lowered taxi window, they come running up to him screaming and hug him. There is a jump cut to the taxis carrying the group of participants arriving to the base of Pereira da Silva and there is a scene full of hugs and kisses as the boys' families and more friends welcome them home with a large cake. When one of the boys remarks that they got a bigger reception than they deserved, an unidentified woman comments back, "That's because you have friends." ${ }^{51}$ A community feeling is one of the several benefits that the participants talked about as a benefit of Pereira da Silva. Another benefit is the central location of the community.

Well located. Pereira da Silva sits on the hill which straddles the historic and Bohemian Santa Teresa neighborhood and the upper-middle class Laranjeiras neighborhood. Depending on where in the community one lives, it is about a 15 -minute

\footnotetext{
50 "Onde todo mundo se conhece, onde todo mundo se fala, todo mundo. Todo mundo não se gostas, mas a rapaziada é maneira, legal, zoa, brinca. É uma mãe essa comunidade. É uma mãe. Porque tipo assim, se você chegar, como eu posso dizer que isso aqui é uma mãe? Você aqui vai ser sempre muito bem recebido pelos outras. Se você precisar todo mundo vai passar a mãe na sua cabeça, vai te aconselhar 'olha não faz isso por cousa disso, disso e disso'. Então esse morro é uma mãe."

51 “Isso é porque vocês têm amigos.” Deus sabe tudo mas não é X-9. 00.41.49- 00.42.23
} 
walk to bus lines and about a 20 -minute walk to a metro stop. Just outside of Pereira da Silva there is commerce and entertainment. Many of the participants cited this location as a benefit of living in the community (i.e., Gão, Rafael, Renato, Rodrigo). Gão emphasized the closeness to work opportunities and easy access to public services. In normative-evaluative terms, Gão communicated that there can be benefits of living in certain favelas, and there should be societal recognition of these positive aspect.

Living in the South Zone, because here it's close to everything, the area for work is always here in the South Zone or downtown. Here I am close to everything, and the opportunities are the best... the hospital is the best, transportation. ${ }^{52}$ Rodrigo also described as a benefit of living in Pereira da Silva the closeness to the city center, easy access to mass transportation, and shopping close by.

It's a luxury in relation to a lot of things. Here we are in the middle of the South Zone, you see? Twenty minutes from here there is a beach if you want to go on foot. If you want to go by bus, it's less.... Here also, if you want to go down to the street, you have a movie theater, you have a lot of grocery stores, there's a pharmacy. There's everything close. Here there's a church. So we are close to everything. We live in a comunidade, but it's a comunidade of luxury. ${ }^{53}$

In what I witnessed, many of the people whom I know who live in Pereira da Silva do not own their own cars. This may be due to financial restrictions, or it may be the traffic

\footnotetext{
52 "Morar aqui perto da Zona Sul, que aqui é perto de tudo; a área de trabalho é sempre por aqui na Zona Sul ou então ali no Centro. Aqui eu estou perto de tudo, as oportunidades também são melhores... hospital é mais perto, as conduções."

53 “Um luxo em questão de um monte de coisa. Aqui a gente está no meio da Zona Sul, entendeu? Há vinte minutos da praia, se você quiser ir andando. Se você quiser ir de ônibus é menos.... Aqui também, se você descer a rua, você tem um cinema, você tem um monte de supermercado, tem farmácia, entendeu? Tem tudo perto. Aqui tem uma igreja. Então a gente está perto de tudo. A gente mora em uma comunidade, mas é uma comunidade de luxo, entendeu?"
} 
conditions in the city detracted from their desire to own a car. Being centrally located can add a great deal of quality to someone's life.

Violence and unlawfulness. Many of the participants of this study qualified Pereira da Silva as being relatively calm and free of violence from the traffickers and police, but many of them also gave the existing presence of both factors as one of the largest detractors of living in Pereira da Silva (i.e., Budé, Cilan, Felipe, Luciano, Pedro, Rafael, Rani, Renato).

Luciano talked about his experience living in the asfalto for a short period, and compared it to life in Pereira da Silva. He saw drawbacks living in the asfalto, but said that there was less of a chance of a resident getting hit by a stray bullet while coming home from school or work in a favela. Luciano also explained that safety concerns used to be much worse in Pereira da Silva around the time that Morrinho was first started. There is still a visible presence of drug trafficking. The point of sale of drugs for the community is close to the base of the entrance from the Laranjeiras neighborhood. In order to get to the majority of the houses, one must pass a gathering of mostly men that patrol the area, and sell cocaine in small plastic bags. It is also a common site for public smoking of marijuana. However, as opposed to the display of large automatic weapons in other communities, the traffickers carry hidden weapons in Pereira da Silva.

Oh, I've already lived in my aunt and uncle's house and all, it is very different, you don't run a risk there... at least at my uncle's house I didn't run a risk. It was a calm place, but without neighbors, so it was different. Here no. Here at any hour there could be a conflict inside the comunidade. A conflict is like as if it 
were a war, a fight between the police, the people of the government, the police and the guys from the comunidade who make, let's say, poor choices. ${ }^{54}$

Rani is the only one of the participants who talked about personal loss due to the violence in the community. He attributed Morrinho as a positive influence in his life that afforded him trips to Europe while some of his peers in Pereira da Silva were becoming involved in the trafficking. In normative-evaluative terms, Rani communicated that becoming involved in the organized crime is rather common for local youth, but there can be serious negative consequences for this type of association. Youth development organizations such as Morrinho can be very influential in the lives of youth from favelas, and there should be more support for such organizations in order to allow more youth to mature in to healthy and productive members of society.

When we were traveling and everything, there were others that didn't have this same luck, they abandoned the project and they ended up dying. This could have happened to almost everyone in the project, if the project didn't exist. Because, when you live in a comunidade, in a favela, there is no incentive, you end up on the 'wrong side', the 'wrong path. The 'wrong side' is the trafficking of drugs. Many became addicted to drugs, and a lot ended up becoming traffickers themselves.... They die, either the police kills them or other drug traffickers will kill them when they mess up. ${ }^{55}$

\footnotetext{
54 “Eu já morei na casa dos meus tios e tal, é bem diferente, o ambiente você vê que não corre perigo... pelo menos na casa do meu tio, eu não corro perigo nenhum. A minha volta, um local tranquilo, sem vizinhos do lado, então, é diferente. Aqui, não. Aqui, a qualquer hora, pode estourar um conflito, dentro da comunidade."

55 “Enquanto alguns de nós viajamos e tudo, tiveram outros que não tiveram a mesma sorte, abandonaram o projeto e acabaram morrendo. Isso poderia ter acontecido com quase todo mundo do projeto, se não
} 
Both Luciano and Rani, and several of the other participants, used the language of o caminho errado [the wrong path] and o lado errado [the wrong side] to talk about participation in the drug trafficking. As Rani, stated above, several of the participants say that they themselves could have ended up as a trafficker had things been different, and had they not been a part of Morrinho. Also in this language is an absence of blame being placed on those who are traffickers themselves, but on the decisions the adolescent boys make. This is to say that the trafficking presence victimizes adolescent boys into participation. These boys fall victim to a lack of opportunity that they see in their neighborhood and in their social networks. According to Luciano and Rani, this hopelessness can lead to poor choices, and death. The violence and lawlessness that exists in Pereira da Silva is something that none of the participants admitted to liking or condoning, and nearly all of them touched upon this being a negative quality of Pereira da Silva, the trafficking and the combat between the police and the factions is something that most of them saw as a complex social issues.

There is a scene toward the end of the documentary that gives the viewer much to think about as far as the police's aggressive stances toward Pereira da Silva. In March of 2007 , after the original group of youth had been recognized as artists for some years in Brazil and various European countries, a reporter was interviewing Cilan on Morrinho's trajectory from a game to being recognized as a work of art. As Cilan finished explaining the positive impact that he thinks Morrinho has had on Pereira da Silva, a long series of gunshots were fired close by. There is confusion as evidenced by the shakiness of the

existisse o projeto, porque, quando você mora na comunidade, na favela, que não tem nada assim de incentivo, você acaba entrando nesse lado errado, no caminho errado. O lado errado é o tráfico, né, as drogas. Muitos viram viciados em drogas, e muitos viram traficantes mesmo.... Ah, morrem, ou a polícia mata, ou os próprios bandidos matam quando eles vacilam." 
camera that was filming them, then there is a shot of a black helicopter flying low close to Cilan and the reporter. The reporter later explained that the interview was cut short due to the police helicopter shooting at them. The reporter said, "The police helicopter flew over the comunidade and probably mistook our TV crew as drug dealers." ${ }^{, 56}$ This scene was a good example of the incidents of violence that occur in Pereira da Silva. When they happen, fear is incited. However, the violence is no longer a regular occurrence in this Pereira da Silva.

Lack of government services. The lack of government services is an issue that defines what a favela is at one of the most basic levels. The favelas grew with the settlement of people who could not afford to live in the incorporated city. A few of the participants made it a point in their interviews to say that not everybody who lives in Pereira da Silva is impoverished (i.e., Cilan, Luciano, Maiquinho, Rani, Rodrigo). Rani highlighted the negative social implications that he believed lay in the word comunidade. "It's an impoverished comunidade, there are people in need, but there are a lot of people who are not impoverished who reap the fruits of the comunidade. There are people who have eight houses for rent. ${ }^{, 57}$ However, Rodrigo elaborated on the consequences of power outages in the favela which were much longer than what happens in the asfalto.

When there is no power, it's not that it will only be on the morro. Light [the power company] will take two or three days to get here. So, you are without power for two or three days. Sometimes you'll have just bought meat, you buy

\footnotetext{
56 "O helicóptero sobrevoou a comunidade e provavelmente confundiu a nossa equipe de filmagem como traficantes." Deus sabe tudo mas não é X-9. 01.00.06-01.01.06

57 "Ela é uma comunidade carente, tem muita gente que precisa. Mas tem muita gente que não precisa, que tira os frutos da comunidade. Tem gente que tem 8 casas alugadas."
} 
something and it's in the fridge, and it spoils. When there's no power on the morro, the power's out on the asfalto too, but there in half and hour max it's back on. It's a big difference. ${ }^{58}$

Luciano talked about the lack of development leading to few opportunities for the children of the community to play in safe areas. He, and several of the other participants, sees the limited space for the children to play as contributing to the social problems that the residents must deal with. As Luciano talked to me, he contrasted his childhood which was full of opportunities through Morrinho when the organization was more active with kids and had more funding. In normative-evaluative terms, Luciano communicated that if there were more support for youth development programs, there would be fewer social problems. In order for this to happen, the successful application long-term sociallyoriented political policy is necessary. Similar to how I witnessed other participants speaking, Luciano avoided directly talking about the trafficking, but calls it a “connection" to illegal and bad activity.

A social problem is children who could have more sport, a place to practice sports, people to come and teach them. Since I've had experiences outside [of Pereira da Silva], I see that this is missing here, to take the kids out of the link, this connection to that which is not legal, the connection to bad things in the comunidade. So it would be better if the kids had more to entertain them. ${ }^{59}$

\footnotetext{
58 “Se faltar luz só no morro, a Light demora dois, três dias para subir. Então você fica dois, três dias sem luz. As vezes você compra uma carne, compra alguma coisa, está na geladeira, daí estraga, entendeu? E assim, quando falta luz no morro que falta na rua também, a diferença é muito grande. Em meia hora, uma hora no máximo a luz já voltou, entendeu?"

59 "Problema social é criança que poderia ter mais esporte, local para praticar esporte, pessoas que venham ensinar isso, entendeu? Como eu já tenho uma experiência fora e tal, vejo que aqui falta isso, para tirar
} 
Eleven of this study's participants described the benefits of living in Pereira da Silva as a well located, calm environment, with community support (i.e., Betinho, Gão, Junior, Luciano, Maiquinho, Nicolas, Paulo Vitor, Pedro, Rafael, Rodrigo, Teibe). However, the consequences of underdevelopment are complex, and can lead to direct results such as the inconvenience of spoiled meat or the serious issues of adolescence of drug addiction and participation in criminal networks. Despite the described benefits, the participants largely felt that the association with such social ills led to discrimination against them.

\section{Discriminatory Experiences}

Upon asking the participants of this study about the advantages and disadvantages of living in Pereira da Silva, several of them detailed the discrimination that they faced as a result of living in the community. This was in agreement with what the literature reported, that the most common form of discrimination for those who live in Rio's favelas, and in Brazil in general, is the label of being a favelado (i.e., Criistian, Felipe, Gão, Junior, Luciano, Maiquinho, Pedro, Rodrigo, Teibe; Almeida, 2007; Neate \& Platt, 2010; Perlman 2010). Gão explained it to me in a straight forward fashion. "But there is always prejudice.... prejudice that you live in the morro. That you are a favelado and all. ${ }^{, 60}$ All of the participants cited various forms of social stigmas as the basis for discrimination.

\footnotetext{
essas crianças desse vínculo, que é o vínculo que não é legal, é o vínculo de coisas ruins dentro da comunidade. Então, seria bom que tivesse mais coisas para as crianças ocuparem a cabeça."

60 "Mas sempre tem o preconceito." "Do que é o preconceito?" "Preconceito de você morar no morro. Favelado e tal, entendeu?"
} 
Considered a trafficker or a criminal. According Roth-Gordon (2009), the dominant focus of inequality in Rio is focused on the trafficking and criminal activity. Several of the participants told me that they face societal discrimination, because they are sometimes thought to be a trafficker or a criminal for living in a favela (i.e., Cilan, Luciano, Maiquinho, Pedro, Renato, Teibe). According to Luciano, some people automatically associated people who live in favelas with people who live on the outskirts of society and engage in illegal activities, but then points out that this association is a false belief. "They think that who lives in a comunidade are bums, they think that everybody in the comunidade is a criminal. In reality it's not like that." ${ }^{, 61}$

Similarly, Renato told me that many associate those who live in a favela as necessarily being drug traffickers. In normative-evaluative terms, the drug trafficking that exists in the favelas give residents a bad reputation. The few who are directly linked to the trafficking cause discrimination against the many residents who are not directly associated. The security situation in the communities is so grave that Renato believes that there should be a wide-scale long-term political effort to stop the trafficking. "People say that the morro, whoever lives on the morro is favelado, whomever lives on the morro is a criminal, is low-class." I asked, "Low-class because of money, because of education, even how they dress or how they behave?" He replied, "No, because of the trafficking itself." ${ }^{32}$

\footnotetext{
61 “Acham que todos que moram na comunidade são vagabundos, acham que todo mundo na comunidade é bandido. Na realidade, não é."

62 "Pessoal fala morro, quem mora no morro é favelado, quem mora no morro é bandido, é marginal." "É marginal por causa de dinheiro, por causa de educação, por causa de como se vestem, como se comportam?" "Não. Por causa de tráfico mesmo."
} 
Reminiscent of Leeds (2007) and Arias and Rodrigues (2004), Pedro talked to me about the discriminatory practices of the police, and the social stigma of being a criminal since he is from a community.

Sometimes there's discrimination. If you go to the asfalto and you are checked by a police officer, he asks where you live and you explain and the guy sometimes calls you a pothead, he curses at you.... I don't know, I think that the people from the asfalto see favelas in another way. I don't know. It has to be that. In the street, sometimes when I'm going down on my motorcycle and I'm stopped by a police officer, the guy looks at me and asks right away already full of arrogance, you know? He's already interrogating me. And he thinks that I have drugs in my bag, only because I'm coming down from the morro on my motorcycle, he already thinks that I am an addict, a criminal, or something like that. They've already stopped me. The guy didn't even ask my name and he already had me against a wall trying to search me.... Whomever stops there and sees you descending is going to look at you in another way. Now, if he stops there and sees you coming out of an apartment building, he's not going to act the same way as he does with the people who are descending from the morro. ${ }^{63}$

\footnotetext{
63 “Às vezes tem discriminação. Se sair na pista e você é enquadrado por um policial ele pergunta aonde você mora e você explica tudo e o cara as vezes chama de maconheiro, te xinga e o 'caralho'. Porque, o pessoal, não sei, eu acho que o pessoal lá de baixo vê a favela de um outro jeito. Não sei, deve ser. Aqui na rua muitas vezes quando eu estou descendo de moto e eu sou parado por um policial o cara já vem e pergunta logo cheio de arrogância sabe? Já vem me interrogando. E acha que eu tenho droga no bolso. Aí só pelo fato de estar descendo pelo morro de moto ele já acha que eu sou viciado, bandido, ou alguma coisa do tipo. Já me enquadra logo, não pergunta nem meu nome já me bota na parede, tenta me revistar....

Quem parar ali e te vê descendo vai te olhar de outra forma. Agora se ele para ali e te vê saindo do prédio. Ele não vai fazer o que ele faz com a rapaziada que está descendo o morro."
} 
Maiquinho broadened the conversation to not only talk about how favela residents are treated in Rio de Janeiro. He talked of his criticism of how the communities are viewed in other countries.

Favelas outside of Brazil are very discriminated. Actually, it's not discrimination, but they're known for violence.... In other places a lot of times they depict the comunidade, the morro, the favelas as a place of violence, only things of violence. And it's not like that. The truth is that it's not like this. The morro doesn't only have this, it has celebrations. People get together, they barbecue, they celebrate birthdays with everybody together.... There are churches, social projects in a lot of the comunidades. There are comunidades that do not have drug trafficking. ${ }^{64}$ All four of the above participants talk about favelas being linked to drug trafficking and this being a cause for discrimination, but they all reject this being true.

God Knows Everything But He's Not A Snitch recounted how the project of Morrinho has been associated as a plan from one trafficking faction to invade the territory of another. There is a scene early on in the documentary when Cilan is introducing Morrinho to two of Rio's de Janeiro's well-known funk musicians, Fernanda Abreu and DJ Marlboro. He explained how the police came to the project once when he and a group of boys were playing. They started to destroy the model and demanded that the boys tear it down. As Sérgio Correa, a community leader, explained, this was during a time period when there were a lot of police incursions and the police thought that the Morrinho model

\footnotetext{
64 “A favela fora do Brasil é muito discriminada. Na verdade, não discriminada, mas conhecida por muita violência.... Lá fora, escracham muito a comunidade, o morro, a favela, como violência, sabe? Só com coisas violentas. E não é isso, a verdade não é essa. O morro não vive só disso, tem festas. As pessoas se reúnem, fazem churrasco, comemoram os aniversários todo mundo junto.... Tem comunidades que não tem tráfico de drogas."
} 
was a plan of one trafficking network to invade other favelas. Cilan explained that a young age he was threatened by the police with guns nearly the size that he was. ${ }^{65}$

Poverty stigma. Being discriminated against for being impoverished was nearly as commonly mentioned by the participants as facing discrimination for being associated with criminal activity (i.e., Criistian, Felipe, Junior, Paulo Vitor, Renato). Paulo Vitor and Criistian talked about race and poverty being the reason that favela residents are discriminated against. "There is a lot of prejudice, also because of skin color, and for living in a favela... for not having a lot of opportunities, for living in a favela, for being poor." ${ }^{66}$ According to Paulo Vitor, there is such a division between the favela and the asfalto that the population of one area does not commonly know the values of the population of the other.

They think that whoever lives in the morro is poor, that he doesn't have conditions for anything, and that it's going to be like that for his whole life. Everybody thinks this. But here in the morro it's not like that, everybody works. Everybody is chasing his goals every day, waking up early, going to bed late. Everybody is trying to take care of himself. Only, they are going to face this prejudice for the rest of their life. ${ }^{67}$

\footnotetext{
${ }^{65}$ Deus sabe tudo mas não é X-9. 00.12.34-00.14.32

66 "Muito preconceito, também pela cor, por causa de morar na favela... pelo jeito de não ter muitas oportunidades, de morar na favela, de ser pobre."

67 “Acham que quem mora no morro é pobre, que não tem condição de ter nada, isso aí vai ter a vida inteira. Todo mundo vai achar isso. Mas aqui no morro, todo mundo trabalha, todo mundo corre atrás do seu todos os dias, acordando cedo, dormindo tarde. Está todo mundo em busca do seu. Só que esse preconceito vai ter para o resto da vida."
} 
Favela residents are labeled as being cyclically impoverished, but this label is not always deserved nor is it true. In normative-evaluative terms, the resulting prejudice based on incorrect information is the basis for enduring discrimination.

Employment discrimination. As Perlman (2010) termed it, only the very rich and the very poor in Brazil live in houses. Rani told me how when he looked for jobs in the past, his chances of being considered were lessened after the employer found out his address. He gives the reason as association with a violent population, or drug trafficking. First, at the beginning, before I was working in a formal job I was looking for a job. Not just me, a lot of the people from the comunidade. So, when we would get to the place, we would fill out an application. When we would say that we lived in Pereirão, people already lost interest and they'd say for us to wait for their call, but they never called. So there is that discrimination. If you'd say that you lived here, since the comunidade was very violent, it was always on the TV for shootouts, deaths, police coming here every day, and we suffered discrimination. $^{68}$

Through informal conversations that I had with other residents of Pereira da Silva, I came to understand that the practice of giving a fake address at places of employment was a common. In normative-evaluative terms, Rani communicated that there is not equal opportunity for life chances for residents of favelas. The employment discrimination has

\footnotetext{
68 "Primeiro, no início, naquela época antes de eu começar a trabalhar de carteira assinada, eu procurava emprego. Não só eu, como muitas pessoas da comunidade. Então, quando a gente chegava nos lugares, aí a gente fazia a ficha e tal. Quando falava que morava aqui no Pereirão, as pessoas já desanimavam e falavam para a gente ficar aguardando em casa. E a gente nunca era chamado. Assim, já tinha uma discriminação, assim, nessa parte, entendeu? Se você falasse que morava aqui, como a comunidade era violenta, estava sempre passando na televisão tiroteio, mortes, polícia vindo aqui todos os dias, a gente sofria uma discriminação."
} 
serious consequences of the livelihood of favela residents. Providing a false address is seen as a way of coping in the face of discrimination.

Racial discrimination. As is also documented in the literature (see Telles, 2004), six of the participants also mentioned race as being the basis for discrimination (i.e., Budé, Betinho, Cilan, Criistian, Felipe, Maiquinho). The twins, Budé and Betinho, talked about racial discrimination most thoroughly. Budé told of an experience of his treatment by the police in a large department store when he entered with a friend who is White. He also mentions a demonstration in class difference by calling his friend a playboy. In my experience with the Morrinho participants and the residents of Pereira da Silva, I understand that a playboy is someone who physically demonstrates wealth in they type of clothing that they wear and what they do for entertainment. Budé said that he was watched much more closely by the security even though he felt that his White playboy friend was acting in a more inappropriate way. In normative-evaluative terms, Budé communicated that there is a racial and class structure in Rio de Janeiro that discriminates against Blacks and those who are impoverished. He believes that there should be a stronger movement toward equality.

For example, I went with a friend to the market, to Lojas Americanas, I'm Preto and he is White. I walked in and a police officer kept watching me, but didn't look at him [the friend], and it was him who was causing a disturbance, and I didn't do anything wrong. But he [the police officer] didn't look at him [the friend] because he lives in the asfalto and is a playboy. ${ }^{69}$

\footnotetext{
69 “'Fui eu e um amigo entrar, por exemplo, no mercado, nas Lojas Americanas, eu sou o preto, o menino é branco. Eu passei, assim, o polícia ficou me olhando, mas não olhou para ele. E ele que ia fazer merda, e eu não fiz merda. Mas não olhou para ele só porque ele mora no asfalto e é playboy."
} 
Budé's twin Betinho gave a similar account of racial discrimination that is akin to what he has experienced. Betinho talked about what happens when he enters a public sphere wearing his customary choice of clothing as opposed to changing what his clothing would be in order to blend to middle class norms.

You enter into a market, and if I enter with normal clothing, the security guards will send someone to watch me. And if a well-dressed White person enters, they don't say anything... I think that it's because of the color of my skin, because they think that everyone who is preto, no, that every negro is a criminal, something like that, but it's not the case. ${ }^{70}$

I have left the racial classifications that Budé and Betinho use in the original Portuguese because I believe that their word choice here emphasizes what they are aiming to communicate. When I asked each of them what race they were, they both changed their classification. Betinho changed his race from preto to moreno explaining that moreno is lighter. Budé changed his classification from negro to preto explaining that preto is darker. In the above comments on discrimination, Budé maintained his identity of being preto, but Betinho's comments switched from a classification of preto to one of negro. Budé and Betinho exemplify the discussion of the fluidity of racial identity in Brazil. As reported in Telles (2004) and Gates (2011), a Brazilian's racial identity can be changed depending on what situation they are in. Also keeping with what Neate and Platt (2010) reported, the twins generalized darker skin with facing more racial discrimination.

\footnotetext{
70 "Entra você no mercado, e se eu entrar com roupa normal, os seguranças já mandam um radio para ficarem me olhando. Aí se entra uma pessoa branca arrumadinha, assim, eles não falam nada... acho que é o caso da pele, porque eles acham que todo preto, não, todo negro é bandido, esses negócios. Mas nem todos são."
} 
Efforts to avoid discrimination. A few of the participants talked about efforts to avoid discrimination using certain clothing, or acting a certain way (i.e., Felipe, Gão, Maiquinho, Nicolas, Rodrigo). This agrees with the discussion that Perlman (2006) contributed to favela youth spending much or all of their income on clothing and products that help them appear to be middle class residents of the asfalto. Maiquinho expressed anger and frustration at the thought of discrimination and explained the mutable nature of perceptions.

If I'm clean, smell good, wearing the best perfume, you're never going to imagine that I live in a comunidade. If you like a pretinho, you're going to think that I'm attractive. So, until the moment that someone introduces me to you and you ask, 'Where does he live?' 'He lives in a comunidade.' If you have any type of prejudice, you're going to show it then, you won't want anything to do with me. There's always these antics. ${ }^{71}$

Gão expressed to me that discrimination for living in a favela was not always a regular occurrence, because many residents make efforts to act and appear like someone from the asfalto. In normative-evaluative terms, Gão communicated that there exists discrimination in Rio de Janeiro, but by changing demonstrations of personal identity, a person can avoid or mediate such discrimination.

We worry about our image, so what happens? You don't want to face this prejudice, so what do you do? You try to act a certain way, you try to get others

\footnotetext{
71 "Se eu estiver limpinho, cheiroso, exalando o melhor perfume, você nunca vai imaginar que eu moro em uma comunidade. Se você gostar de um pretinho, você vai me achar lindo. Mas, enfim, a partir do momento que uma pessoa me apresenta a você, "Ele mora aonde?" Ele mora na comunidade. Se você tiver algum tipo de preconceito, você já vai demonstrar ali, você não vai querer um vínculo comigo. Sempre tem essas palhaçadas."
} 
to act this way, whomever is close by so you try to not call a lot of attention to yourself, and well, life goes on. ${ }^{72}$

As Nicolas talked to me about discrimination, he seemed to not have internalized discrimination based on where he lives or what he looks like. Discrimination is what may happen to other people because of how they act or dress, but Nicolas described the efforts he makes so that he will be respected.

I do anything I can so I won't face prejudice. How? I dress well. You see, so I won't face prejudice in the street. I say, 'Excuse me, could I help you with something.' So people treat me well. If you say instead 'Hey, you have to tell me this here, I am...' Forget it! You already lost the person's confidence, so the person is going to be prejudiced against you no matter that you are White or Preto. $^{73}$

While five participants talked to me explicitly about the way that they can change their appearance or mannerisms to avoid discrimination, I believe that such behaviors are practice on a regular basis by more of the participants. In my experiences with the Morrinho participants and other residents of Pereira da Silva, I regularly heard people talking of, and I witnessed residents dressing in, nicer clothes to go to the asfalto.

\footnotetext{
72 “A gente também se preocupa com a imagem, aí o que acontece? Você não vai querer passar por esses constrangimentos, aí procura o que? Procura se comportar e tal, procura passar esse comportamento para outras pessoas, para quem está do seu lado e assim tenta não chamar muita atenção, mas a vida continua."

73 “Eu já faço o máximo possível para não passar preconceito. Como? Vou me vestir bem! Está entendendo? Então eu já não passo preconceito na rua. As pessoas me tratam bem, eu trato bem as pessoas. Mostro que... Chegar assim nas pessoas "com licença, posso te informar isso". Então as pessoas vão te tratando bem. Então se você chegar lá "pô, tem como me informar isso aqui que eu too...", ai já era! Já perdeu a confiança com a pessoa, então a pessoa vai te dar... sem vai ter preconceito. Quanto o branco como o preto."
} 
Thirteen of the 17 participants of this study talked about specific type of discrimination that they themselves and others whom they know have faced. The various types of discrimination mentioned were based on being considered a trafficker or a criminal (i.e., Cilan, Luciano, Maiquinho, Pedro, Renato, Teibe); based on a stigma of poverty (i.e., Criistian, Felipe, Junior, Paulo Vitor, Renato); employment discrimination (i.e., Rani); and racial discrimination (i.e., Budé, Betinho, Cilan, Criistian, Felipe, Maiquinho). However, five of the participants described to me efforts that they make to avoid discrimination (i.e., Felipe, Gão, Maiquinho, Nicolas, Rodrigo). This consists of ways of dressing, ways of acting, and ways of talking.

\section{School Experiences}

There is no school in Pereira da Silva, so the majority of the participants attended the schools in the Laranjeiras neighborhood, and two attended private schools in their early years. I asked the participants to describe their school experiences ${ }^{74}$, and a common follow up question asked about their teachers. ${ }^{75}$ Based on the literature reviewed, I expected the participants to be highly critical of the likelihood of grade repetition and high dropout rates (Cardoso \& Verner, 2007; Ireland, 2007); the near unattainable nature of university for public school students (Reiter, 2009); and high rates of absenteeism of teachers (Gatti \& Barretto, 2009). However, there was not universal criticism of the schools that the participants attended.

A positive experience. Four of the participants explained their school experience as generally good (i.e., Nicolas, Paulo Vitor, Renato, Teibe), and five of them said that

\footnotetext{
74 "Como descreveria onde mora?"

${ }^{75}$ Como eram seus professores?
} 
they generally liked their teachers (i.e., Betinho, Gão, Nicolas, Pedro). Nicolas was expressive in his support for the education that he received in his local public school. Talking about his teachers, he told me,

There are teachers who you can see know how to manage a class, they know how to teach, they are patient with the students. Whomever is causing a disturbance in class, they don't pay attention to this. They do whatever they can to get those kids to pay attention. 'Hey, pay attention.' If they continue to cause a disturbance, what do they do? They ignore them. "And what do you want? I've already got my degree!"76

Nicolas told me this with expressed admiration for his teachers and as support for his point that he had a positive school experience. It is possible that through his experiences with Morrinho, Nicolas came to value the structure and guidance by some of his teachers at school. Seventeen years old at the age of his interview, Nicolas was one of the youngest to participate in this study. The views that he expressed above reflected the role that he had at Morrinho as a member of the younger generation. It is this structure and guidance that has allowed Nicolas to mature.

Gão and Pedro gave a generally positive description of their school experience, but put more emphasis than Nicholas on the challenges they faced with certain teachers. Gão said,

I learned a lot of things. The teachers always did the best that they could to be.

There were some teachers who were hardheaded and tried to get in our heads

\footnotetext{
76 “Ah porque dá para ver, assim, tem professores que dá para ver que eles sabem dar aulas, eles sabem ensinar, tem paciência com o aluno. Aqueles que estão fazendo bagunça ele vai deixar de lado. Ele vai tentar fazer o máximo possível para ajudar ele. "Fulano, presta atenção". Se quiser ficar na bagunça, quer fazer? Vai deixar de lado! "É isso que você que? Eu já estou formado!".
} 
something that wasn't possible. It's not possible with everybody. 'I don't

understand what this teacher is saying,' everyone would say. It's not possible. So

everyone was confused, it's not possible. Some teachers are like that, but I really

did learn a lot of things. ${ }^{77}$

When I asked Pedro if he was interested in what was taught in school, he told me,

Yeah, I'm interested. Some of the stuff is cool. At first it's difficult, he [the teacher] writes a lot of stuff on the board that you don't understand. But then he explains it, you pay attention, and then you learn. So everything is easier. There are some teachers who are kind of, they don't know how to explain the material, but you can understand if you pay attention and are patient. ${ }^{78}$

Teibe explained that in general he liked school. "Yeah, I liked school. It was good, because my friends were there. You meet different kinds of people, and you go there to study too. I learned a lot of things in school."79 While Teibe generally liked his school experience because of the social atmosphere and the learning that went on, he was not

\footnotetext{
77 “Aprendi muita coisa. Os professores sempre dão o melhor de si para poder... Tem alguns professores que são "cabeça dura" e tentam botar coisas na nossa cabeça que não dá, não é? Não é possível que todo mundo, não é? "Não estou entendendo o que esse professor está falando." Todo mundo, a classe não entender e o professor, não é? Não é possível. Então, está todo mundo burro. Não é possível. Alguns professores são assim, mas aprendi muita coisa mesmo."

78 "É, estou interessado. Até que é maneiro as paradinhas. No início isso é difícil, ele fica mandando um monte de negócio no quadro que você não entende nada. Mas depois ele te explica, você presta atenção, aprende na moral. Aí fica tudo mais fácil. Tem alguns professores lá que são meio, não sabe explicar a matéria, mas dá para entender com muita atenção e paciência dá para entender."

79 "É, eu gosto da escola, é bom, porque tem os amigos, conhece mais pessoas diferentes, e vai para estudar também, né. Aprendi muitas coisas na escola, cara."
} 
entirely favorable of his description of his teachers. "Oh, some teachers are annoying, they nag you a lot. I really don't like this." ${ }^{, 80}$

In normative-evaluative terms, the social aspect of school is important for youth development, and school would be more enjoyable if the social and academic aspects were merged more successfully. Seven participants said that the highly criticized schools for favela youth are not all bad. However eight participants talked to me about how their school experience could have been better.

A negative experience. Eight participants either told me that they didn't like school, or did not get good grades, or did not find it applicable to their lives (i.e., Betinho, Budé, Felipe, Junior, Maiquinho, Rani, Rodrigo, Teibe). Junior and Rodrigo explained how when they were in school they didn't like it. Junior criticized the disconnect between school and the real world, and explained how he had to work while he studied. In normative-evaluative terms, Junior communicated that many times youth of limited financial resources must work and this can lead to disinterest in school. However he also communicated that there can be experiences in a child's life as valuable to their developmental and learning as school can be. Finally, Junior communicated that schools would be more effective for some youth if they reflected real life applications.

I didn't like studying very much. I don't have patience to stay inside a classroom for very long, even because when I was studying, I had other jobs, I was working, I was here at Morrinho. So I would get to class tired, already wanting to leave.

\footnotetext{
80 “É, tem alguns professores que são chatos..." “É, porque pegam muito no seu pé, não gosto muito,
} não." 
Because, what I was seeing in class, there were a lot of things we didn't use in real life. ${ }^{81}$

Rodrigo explained how his active personality did not lend itself well to the sedentary nature of school.

I don't have a lot of patience to study, like I didn't like waking up early because I was obligated to, because my mom and dad made me go. So I went. I ended up liking school, but not because of the studying, but because I would play ball and make friends with the other kids. We got to know each other and we would skip.

I went from school more to the beach, to the mall, more to hang out. Not to study, because I never went to study. ${ }^{82}$

Felipe was more critical of their experiences in school. He cited the problem of excessive teacher absences that was addressed in the literature (Gatti \& Barretto, 2009; Reiter, 2009). "For me, public school has a lot of teacher absences. I would go to primary school and I would come home early almost everyday because the teachers were absent a lot. In the secondary school, the teachers are there more, it's less likely that they

\footnotetext{
81 "Eu nunca gostei muito de estudar. Eu não tenho muita paciência para ficar na sala de aula por tanto tempo, até porque quando eu estava estudando, eu estava também fazendo outros trabalhos, estava trabalhando, estava aqui no projeto. Então, eu já chegava na sala de aula cansado, já querendo sair. Porque pelo que eu vi nas aulas assim, tudo bem, mas tinha muitas coisas que a gente não usa no cotidiano da vida."

82 "Porque eu não tenho paciência para estudar, assim, eu não gostava de acordar cedo e ia porque era obrigado, porque minha mãe e meu pai me mandavam ir. Então eu ia. E assim, depois eu acabei até gostando da escola, não por estudo, mas eu ia para ficar jogando bola, para fazer amizade com meninas e meninos. E a gente ia se conhecendo, aí saía pra outro lugar. Eu ia pra escola mais para ir à praia, para sair e dar uma volta no shopping, mais para curtir, entendeu? Não para estudar, porque eu nunca fui de estudar, não."
} 
will miss. ${ }^{\prime 83}$ The challenges of the schools and the quality of the education contribute to the low graduation rates of Rio's marginalized population.

Difficult to graduate. Several of the participants elaborated on their negative experiences in school by explaining to me how it was difficult for them to graduate (i.e., Felipe, Luciano, Maiquinho, Rani). Rani, one of the three participants of this study who has graduated from high school, talked at length with me at different points of his interview about the challenges he faced in graduating. In subjective terms, Rani communicated that he values education, because he believes that it will increase his life chances. A school diploma is generally regarded as the gatekeeper to a more prosperous career. However, he feels that he has had to work harder than other students at graduating, because of his lower class status.

In first grade, right from the beginning, and in second grade, I repeated a year. I repeated first grade, and then I passed, and then I repeated the second grade. Then I was able to find a way to pass without repeating until eighth grade. That's when I pass and went to secondary school, then I dropped out. ${ }^{84}$

Rani explained to me that at the time that he dropped out of school he was working a lot, but with perseverance, he told me of how he was able to finish secondary school. 'I told myself, 'No, I can't not study.' So I started studying again in 2003, and I

\footnotetext{
83 “Para mim, o ensino público perante muitas faltas de professores. Eu ia estudar na escola pública, eu chegava quase todos os dias cedo em casa porque o professor falta muito. Já nos cursos do governo, o professor é mais regular, porque é no máximo um ou dois professores, aí é mais difícil ter falta, entendeu?"

84 "Na primeira série, logo lá no início, e na segunda série, eu repeti de ano. Eu repeti a primeira, depois passei, depois repeti a segunda. Aí depois eu tomei um jeito e fui passando sem repetir, né... Até a oitava série. Aí quando eu passei para o segundo grau, eu abandonei."
} 
was only able to finish high school in 2008." ${ }^{85}$ Maiquinho made a broader analysis of the social issues that make it difficult for youth from favelas to graduate from school, and addressed a similar perseverance that Rani talked about. Similar to Teibe's complaint about teachers nagging, Maiquinho communicated that the teachers were not understanding of the students' situations. He also addressed the added challenges that a student from a favela might face and the likelihood of favela children succumbing to negative influences.

People who live in the comunidade have to have the desire to be somebody in life if they depend on public education. They have to have a million reasons to want to be somebody in life, because it's not easy. The education is weak.... I don't want to say that all schools are like that, but the problem isn't always the studying, the problem I think too is the perseverance that a kid from a comunidade needs to have. If he lives in a violent comunidade, he's going to see a million things that may end up attracting him to the wrong side. A lot of times the kids end up being involved in the wrong side. ${ }^{86}$

Rani also expressed frustration in his lack of access to a quality university education. He specifically addressed the high cost of tuition, and his poor preparation to take the entrance exam, the ENEM, a form of the vestibular test that is required to attend

\footnotetext{
85 “Falei, 'Não, não posso ficar sem estudar.' Aí voltei a estudar, aí de 2003 eu só vim terminar o segundo grau em 2008."

86 "A gente que mora na comunidade tem que ter muita força de vontade para ser alguém na vida se depender do estudo público, sabe? Tem quer milhões de vontades de ser alguém na vida, porque não é fácil. 0 estudo é fraco.... Não digo que todas as escolas são assim, mas o problema não é somente o estudo, o problema também acho que é a força de vontade de uma criança que mora na comunidade. Se ela mora em uma comunidade violenta, ela vê milhares de coisas que acabam atraindo ela para o lado errado. Muitas vezes, acaba atraindo a criança para o lado errado."
} 
university in Brazil. As a result of the poor preparation for university, Rani talked about how most public school students are shut out of the competitive free education at Brazil's public universities.

These days I'm thinking of going to college. I wanted to, but it's difficult for us. It's difficult because I finished high school, but we have to pay to study and it's very expensive, I don't have the resources. And it's difficult to get in with the ENEM.... I tried it once, but I didn't get a very good grade. I took a testpreparation course at a university, but I only got a $25 \%$ scholarship, I'd have to pay 75 percent, and I thought 50 percent for me is already a lot... I always studied in public schools... The best universities are public and in the public universities, only the best get in, a lot of whom studied in private schools, who studied a lot more than us, they can get in. And we who really need it, we don't get in..$^{87}$

Present in the discussion of both Rani and Maiquinho is a social awareness that they are part of a larger sector of society who are disadvantaged to the point that it makes them less likely to graduate from secondary school. This consequence leads to lesser life chances and long-term income possibility. The education quality is one of several disadvantages that the participants told me that they deal with. However, in describing

\footnotetext{
87 “Aí, hoje em dia, meu coisa é até fazer uma faculdade. Eu queria... Mas como para gente é muito difícil conseguir. É difícil porque, eu terminei o segundo grau... Mas a gente tem que pagar para estudar, é muito caro, não tenho essas condições. E é mais difícil entrar assim pelo ENEM.... Eu já tentei uma vez, mas não tirei uma nota muito boa. Fiz, assim, um pré-vestibular numa faculdade, mas só ganhei 25 por cento da bolsa, 75 por cento eu teria que pagar. Aí, eu pensei, pô, 50 por cento para mim já era muito.... Estudei sempre em escola pública, mas isso não vem ao caso, porque tem muito estudante de escola publica que consegue. E assim, as melhores faculdade são as públicas, e só entram nas faculdades públicas, os melhores, né, muitos que estudaram em colégios particulares, que estudaram bem mais do que a gente, conseguem entrar. E a gente que precisa mesmo, a gente não consegue."
} 
their educational experiences, the participants were generally not as critical as often presented in the literature (Cardoso \& Verner, 2007; Gatti \& Barretto, 2009; Ireland, 2007; Reiter, 2009).

\section{Summary}

The Morrinho participants agree with the literature that was reviewed in Chapter 2 in many respects of the level of exclusion and inclusion of Rio's favela residents. However, they also had their own individual perspectives on their expeirences living in Pereira da Silva. The participants identified several differences between living in a favela versus living in the asafalto. Among these differences are levels of poverty, lack of space, levels of organized crime, and levels of police violence. They also addresed the marginalization of the Rio de Janeiro's favelas by talking about how the government perpetuates the problems that exist in areas of increased poverty and heightened levels of violence. This lack of attention and inclusive city planning was linked to a furthering of social exclusion. Similar to the divides talked about in the literature, the participants of this study talked about how people who do not live in a favela rarely enter one, and few outsiders really know what life is like inside (Neate \&Platt, 2010; Perlman, 2010). A few of the older participants pointed out that over time the favelas are being incorporated into the city, but these efforts toward progress were criticized by some of the more skeptical younger participants. The participants all voiced the point of view that favela is a derogatory term. It is the term used by outiders, and the dominant population of which they do not consider themselves. The terms that they prefer to call favelas are comunidade and morro. While rejecting the terminology of favela, which is what is used in the literature, the participants agreed with Bourdeiu's (1977) theory of habitus. They 
were able to describe a general style of clothing, preferred style of music, and style of speech that typified a resident of a favela.

The participants of this study spoke to me about their place in society as residents of a favela, but they often differentiated this from their individual experiences of being residents of Pereira da Silva. The problems associated with Pereira da Silva were its violent history, persistent presence of drug trafficking, and lack of government services. However, the community was generally described as peaceful, calm, and well located in the city. The participants also talked about the negative experiences that they have had, despite being from a peaceful and well-located community. They talked to me about discrimination for being considered a trafficker or a criminal, facing a social stigma for being impoverished, employment discrimination for living in a favela, and racial discrimination. However some of the particiapants talked about ways they personally minimized or avoided facing discriminatory behavior. Principal among these techniques was changing the way they dressed and their speech patterns.

Finally, the participants talked to me about their experiences with school. Similar to the literature, all but three of the participants had stopped out or dropped out of school. However, they were not completely critical of the school system. Some said they had many good experiences with the curriculum and their teachers. The most detailed criticism of the school system was the immense difficulty that exists for a marginalized Brazilian to attend university. The following chapter will further develop the themes that were addressed in this chapter, but by looking at the Morrinho organization and the participants' experiences with the organization. 


\section{CHAPTER V}

\section{MORRINHO COMMUNICATING LIFE IN A FAVELA}

This chapter focuses on Morrinho as an organization, its film, and its artwork. Through a process of reconstructive analysis, different truth claims were deduced regarding how Morrinho communicates what it is like to live in favela. The reconstructive analysis that was conducted revealed different types of truth claims that the participants communicated. As will be referred to below, objective truth claims are those to which all individuals have access. Subjective truth claims are those that reveal the thoughts and feelings of the individual. Normative-evaluative truth claims are those that address society and what is generally held as acceptable. A cyclical process was used in this deductive analysis, and resulted in foregrounded, backgrounded, highly backgrounded truth claims which reflect increasingly theoretical application. As in the previous chapter, those participants who addressed each truth claim are noted in parentheses. This chapter will consist of analysis of the interviews, film, and photos of the artwork. As discussed earlier, the photos that I took are titled by a number (e.g., Photo 23, Photo 25). The photos that Nicolas supplied me with are numbered with an $\mathrm{N}$ and a number (e.g., Photo N23, Photo N25).

The participants of this study emphasized the importance that the organization has had in their lives. As an organization that served the local youth, Morrinho is recognized as a game that turned into a refuge from the local violence and trafficking, an opportunity for work and travel, and a social project to help the youth of Pereira da Silva. The participants also described Morrinho as pivotal to their development into adults by allowing them to be recognized as artists, increasing their self-esteem, broadening their 
cultural understanding, and introducing them to positive role models. The participants talked about what Morrinho's film and art communicate to those who see it. The messages that come from Morrinho about living in a favela do not completely reject the dominant messages of violence and trafficking, but go beyond the dominant message to address daily life of residents, advocate for increased acceptance into society, and serve as a positive example of art and culture that exists within Rio de Janeiro's favelas.

\section{Morrinho as an Organization}

Over the course of my volunteer work with Morrinho and my efforts to promote the project in the United States, I had to do a lot of explaining of what the name meant. For this research I wanted to make sure that I was correct in my interpretation, so I asked all of the participants why this name was given to the project. ${ }^{88}$ All of the participants told me that it is a reference to favelas. However, only three of the participants primarily used the word favela to describe the project (i.e., Criistian, Paulo Vitor, Rani). Two used the word comunidade (i.e., Betinho, Budé), and 11 used the term morro (i.e., Cilan, Felipe, Junior, Luciano, Maiquinho, Nicolas, Pedro, Rafael, Rani, Renato, Rodrigo). In Rani's description, he used the three terms to describe the project.

Morrinho means a small favela, a small morro.... It was a name that we chose. It could have been other names, but this is what we chose. It could have been Favelinha, something else like that. But everything would be diminutive. Favela, favelinha, comunidadezinha. ${ }^{89}$

\footnotetext{
88 "Por quê se colocou o nome Morrinho?"

89 “Então, Morrinho quer dizer uma pequena favela, né, um pequeno morro... Foi um nome que a gente escolheu. Poderiam ter sido outros nomes, mas foi esse o nome que a gente escolheu. Poderia ter sido
} 
In addition to asking the participants what the name Morrinho meant, I also asked them to give me a general description of the project. The participants largely talked about the intangible qualities of the project.

\section{A Game, An Opportunity, A Social Project}

The participants made many parallels between Morrinho and the goals of other NFE programs in Brazil (Gohn, 1999; Neate \& Platt, 2010; Simson, Park, \& Fernandes, 2001b; Truet, 2001; Zaluar, 1994). To my general question of how the participants would describe Morrinho, by far the most common responses were that of a game turned refuge from societal ills, an opportunity for work and travel, and a social project to lead local boys away from the negative influences of their community. The participants expressed these descriptions in their interviews, in the film, and as they were talking about the photos of the artwork with me. During my time living in Pereira da Silva, I also noticed that in their everyday speech, and the perception of many residents, that Morrinho is seen in all three ways.

A game turned refuge. During the months that I volunteered with Morrinho in Rio, and the time that I spent performing the fieldwork for this dissertation, some of the Morrinho participants would talk about Lego characters or events that happened in their

play as if they were real. At times I would get confused from their speech as to what was reality and what was play. This was a common demonstration of the continued popularity of the game at Morrinho. Nearly all of the participants, focused on Morrinho being a game that they played (i.e., Betinho, Budé, Cilan, Criistian, Felipe, Gão, Junior,

Favelinha, entendeu, alguma outra coisa assim. Mas tudo seria no diminutivo. Favela, Favelinha, Comunidadezinha." 
Maiquinho, Nicolas, Paulo Vitor, Pedro, Rafael, Renato, Rodrigo, Teibe). These

participants attributed the deep interest that they had in the game making it into a type of refuge that kept them away from the social ills that surrounded them.

Interviews. Renato and Rodrigo explained to me the importance that Morrinho played in serving as a refuge for the kids when Pereira da Silva was experiencing heightened levels of violence. Renato said,

In the time period when it was created, it was a game more for us to, kind of for us to hide. To hide from the trafficking that there was on the morro, because it was pretty bad. We kind of stayed in our own world, closed off, and we stayed away from the trafficking. This was basically Morrinho. It used to be, I think it was a tool to remove, no, not remove. It did not allow us to enter the trafficking. ${ }^{90}$

In my member checking with Renato, he likened the game as Morrinho to a modern-day video game, and he reinforced the characterization of Morrinho as a refuge.

Yes, it was a game that when we started to play, it was as if it were a video game like kids today play. Because of the situation that we were living in, it ended up becoming a refuge for all that played there. ${ }^{91}$

\footnotetext{
90 "Na época, quando foi criado, era uma brincadeira, mais para a gente se, era meio que se esconder, sabe? Se esconder do tráfico que tinha aqui no morro, que era muito pesado. A gente ficava naquele mundinho nosso, fechado lá... e ficava afastado do tráfico. Era praticamente isso, o Morrinho. Antigamente, eu acho que foi uma ferramenta para tirar, para tirar, não. Para não deixar a gente entrar no tráfico."

91 "Sim uma brincadeira que quando começamos a brincar era como se fosse um vídeo game para crianças hoje em dia. Por causa da situação do nosso conviveu acabou se tornando um refugio de todos que ali brincavam"
} 
Rodrigo also talked of Morrinho as a way for them to escape their reality. In subjective terms, the play at Morrinho helped the youth to reinterpret a violent reality as play. This seemed to allow him to more easily confront a difficult lived reality.

Morrinho, when we made it several years ago, it was a way, it was our escape. It was a way for us to leave our reality, which was armed trafficking and shootouts, death, and we were in the middle of this playing with our reality. We saw what was happening and we acted it out here in the form of a game. ${ }^{92}$

When asked how they would describe Morrinho, Junior and Paulo Vitor got a far away look in their eyes. Both of them described it as a magical child's game. Paulo Vitor talked about the child-like playfulness that the project brings back to the participants even now that they are older, some married with children.

I think that it's going to be an eternal game for the entire life of everybody. The older we get, if we are able to, we will always come back. If there's any event, everybody will become a kid again. Grown men with beards, everybody will return to being kids. ${ }^{93}$

Junior likened Morrinho to a toy store.

It was a game, that when we were kids, it was something new and we had so much fun here. Everyone would play, everyone was friends, so we all felt good here. We didn't want to leave. Morrinho is, how do I say it, it is a toy store

\footnotetext{
92 “O Morrinho, quando a gente fez há vários anos atrás, o Morrinho foi uma forma, foi uma fuga nossa. Foi uma forma da gente sair da nossa realidade, que era o tráfico armado e o tiroteio, morte, e da gente sair de dentro disso e brincar com a nossa realidade. A gente via o que estava acontecendo e retratava aqui como forma de brincadeira."

93 "Eu acho que vai ser uma brincadeira eterna, na vida de todo mundo. Por mais que a gente fique velho, se deixar, a gente volta a brincar. Se tiver algum evento, todo mundo volta a ser criança de novo. Marmanjo, de cara barbada, todo mundo vai voltar a ser criança."
} 
where you enter and you never want to leave. You have fun, there is everything for you there, for any kid to have fun. ${ }^{94}$

In normative-evaluative terms, he communicated that youth development projects that reflect the reality and the local culture of the youth make them popular and instrumental in self-esteem and positive identity formation. It is essential that youth have a positive association with an art or leisure activity while they are growing up.

Film. Most of the scenes that position Morrinho as a game come at the beginning of the God Knows Everything But He's Not A Snitch. Several members of the original group chat with the filmmakers in November of 2001, and explain their process of clearing the foliage from the land to be able to build the model. A young Maiquinho explained the popularity of the game from the beginning. Speaking of his older brother Cilan, he said, "He had nothing to do, so he took some tiles, cut them, then he stacked them near the house. The other kids stopped by, started to build streets, and we began to play." 95 There are two other scenes early in the documentary showing the youth playing. Then the play is a focus at the end of the documentary when two visitors to the exhibit at the Venice Biennale play with the Lego dolls at the model. This time the Morrinho participants were not playing, but had been working and their work had become a site of play for others who admitted to admiring the exhibited artwork.

Artwork. Five of the participants selected a total of 15 photos that they explained to me was a representation of the Morrinho model being a game. Speaking of Photo 40,

\footnotetext{
94 “Porque era brincadeira, a gente era criança, era uma coisa nova e a gente estava se divertindo aqui. Todo mundo brincando, todo mundo era amigo, então, a gente se sentia bem aqui. Não dava vontade de sair. Morrinho é um, como vou dizer, é como uma loja de brinquedos, que você entra e não quer sair mais. Você se diverte, tem tudo para você, para qualquer criança se divertir."

${ }^{95}$ Deus sabe tudo mas não é X-9. 00.02.27-00.04.02
} 
Criistian explained that this photo reminded him of when many would come to play on a frequent basis. "This photo here is of a time when everybody participated at Morrinho, would come here, practically every day. We'd come here daily, everybody came here." 96 Nicolas supplied many photos that he had in his possession. They were close-up shots of the Lego dolls set at the Morrinho model when the game was being played. Speaking of Photos N2, N3, N4, and N8, Nicolas told me, "It's like this, in order to kill, like when we are playing, in order to kill another doll, you have to look behind the gun, from behind so you can be sure you are correct. Look there. ${ }^{, 97}$

Referring to Photo 152, Paulo Vitor explained that this was a common site for play. "Because of the space, because of the mobility of playing, I think that everybody here that had a doll came to play, 'Let's go have fun.' So he'd rob a bar, the police came and arrested him. Then another would go to the hotel, he'd eat something and 'No, I'm not going to pay.' He'd leave, and the police would come and arrest him, or kill him, or steal the car. We'd make such a scandal. Someone would drive up in their car, and two dolls would take off with the car. They'd steal the car, and it would be all over. It was so much fun. Fights in the street, we've had everything." 98

\footnotetext{
96 "Porque essa foto aqui é de um tempo que todo mundo participava do Morrinho, frequentava aqui, praticamente todos os dias. Frequentava aqui diariamente, todo mundo vinha aqui."

97 "Que assim, pra você matar, tipo assim, a gente está brincando, pra um matar o outro boneco, o outro personagem, tem que mirar atrás da arma, de trás para você ver que 'tá certo. Olha lá."

98 "Por causa do espaço, pela mobilidade de brincar, acho que todo mundo aqui que tinha um bonequinho vinha brincar, 'Vamos lá zoar.' Aí assaltava um bar, a polícia vinha e prendia. Aí ia no hotel, comia alguma coisa e 'Não vou pagar não.' Saía, a polícia vinha e prendia, ou então matavam, roubavam um carro. Faziam só de sacanagem. Alguém parava o carro ali bonitinho, pegava dois bonequinhos e saía com o carro. Liguei o carro, fui embora e aí já era. Era fogo. Briga na rua, já teve tudo.”
} 
Fifteen of the 17 participants descried Morrinho as a game that served as a refuge from the local ills of their community, and 11 of the participants also emphasized to me the work and travel opportunities that Morrinho made available to them.

Opportunity for work and travel. After describing Morrinho as a game, the next most common way of the describing the project was as opportunity for work, and for travel within Brazil and internationally (i.e., Budé, Cilan, Criistian, Felipe, Luciano, Maiquinho, Paulo Vitor, Rafael, Rani, Renato, Rodrigo).

Interviews. Rafael, who was working close to full time with the organization at the time of his interview, explained the opportunity that Morrinho had created for him. In normative-evaluative terms, Rafael communicated that Morrinho has given him experiences that many residents of favelas would not normally have. The valuable experiences that he has had with Morrinho has allowed him to grow into an adult.

Morrinho, a lot of people see it as a game, and as work too. But for me at the moment it's more like work. Sometimes we have editing work, which is what Cilan does now. We have the work from the expositions too.... The advantages were getting to know different places. Like, for example, I would never imagine me, someone from a favela in Rio de Janeiro, working in the asfalto, travelling to a different country. Like, I went to Holland. There are other guys that went other places. I would never imagine this. Only if I had a job that gave me this, otherwise it would be very difficult. ${ }^{99}$

\footnotetext{
99 “O Morrinho, muitas pessoas vêm como brincadeira, como um trabalho, também é. Mas para mim no momento está sendo um trabalho. A gente as vezes tem o trabalho de edição, que agora é o Cilan que faz. A gente tem o trabalho de exposição também.... As vantagens, foi conhecer lugares diferentes. Como por exemplo, eu não me imaginaria como morador de uma favela do Rio de Janeiro, trabalhando no asfalto eu não poderia conhecer outros países. Como eu fui pra Holanda. Tem outros garotos que já foram para outros
} 
Paulo Vitor also talked about the opportunity to work and travel that Morrinho created for him.

I've been a part of it since the game started, thank God. It's an amazing thing that impacted everybody's life.... The opportunity that it created for us to travel outside of the country, start to work, because we didn't see it as work, we saw it as a game. Everybody, everywhere, always playing. We always wanted to work at Morrinho... but we had real responsibility, everyone worked. ${ }^{100}$

Similar to the work and travel opportunities that Rafael and Paulo Vitor talked about, Luciano told me about how the project was able to introduce him to other cultures outside Pereira da Silva, in the asfalto in Rio de Janeiro, and beyond.

It helped a lot of people, it helped me and it helped other boys in the comunidade, and it continues to help. It gave me a lot of life experiences, in the world outside, that I hadn't had. I started to see people differently. I started to see the asfalto. There's a whole world much wider than the comunidade. So you get to know people of different styles, how do you say it, societies, middle class, middleupper, and upper. I started to see that you could have opportunities. Morrinho, when I started to travel, I started to have this in my mind, the world for me isn't just the comunidade. ${ }^{101}$

\footnotetext{
lugares. Eu não me imaginaria assim. Só se eu tivesse um trabalho que me desse essas oportunidades, mas fora isso muito difícil."

100 "Desde quando começou a brincadeira inteira, eu faço parte. Graças à Deus. Que é uma coisa marcante na vida de todo mundo.... A oportunidade que a gente teve de sair do país, tentar o trabalho - porque a gente não encarava como trabalho, encarava como brincadeira. Tudo, qualquer lugar, sempre brincadeira. O Morrinho sempre estava à vontade... Mas a gente tem responsabilidade, a gente realmente trabalha."

101 “Ajudou muita gente, me ajudou, ajudou outros garotos na comunidade, continua ajudando. Me deu experiências para a vida, para o mundo lá fora, que eu não tinha. Comecei a conhecer pessoas diferentes.
} 
Luciano talked about the value of getting to know what life is like outside of Pereira da Silva, and linked this to teaching them how to act and speak with the middle class and the upper class. Rafael and Paulo Vitor talked of the unlikeliness of the international travel opportunities to be made available to someone with limited finances like himself. They also showed appreciation for the professional opportunities that Morrinho created. However, in my member checking email with Cilan, he emphasized his belief that Morrinho is not a company with employees, "we are not a business that offers work." ${ }^{102}$ He then addressed his idea of how Morrinho is akin to a school.

Film. Among the central themes of the God Knows Everything But He's Not A Snitch are the travel and work opportunities that the original group was afforded. Early in the documentary, the business agreement to make TV Morrinho is reenacted by Fabio and Cilan by using the Lego dolls. This led into a scene where Fernanda Abreu, a wellknown singer and composer, visited Morrinho and exclaimed "Wow, I think this is amazing. You should get paid for this. That's what I think. I think this should be exhibited. What's cool about it is that it's not just static. It's dynamic, you're playing with reality, role-playing what goes on in reality." 103 This scene soon cut to one with the original group making the local news as a positive example of what is happening in Rio's favelas, then there is quick jump cut to show Fernanda Abreu and DJ Marbolo, another

Comecei a ver que lá fora. Tem um mundo muito mais aberto do que aqui na comunidade. Aí, você começa a conhecer pessoas que vários estilos, várias, como se fala, sociedades, sociedade média, médiaalta e alta. Você começa a ver que você pode ter oportunidades. O Morrinho, quando eu comecei a viajar, eu comecei a ter isso em minha mente, o mundo, para mim, não é só a comunidade."

102 "Não somos uma empresa que oferece trabalho."

103 "Pô, acho sensacional! Acho que agora deve ganhar um salário por fazer isso. Eu acho que dever ser exposto assim. E mais legal que não fica só uma coisa parada. Tem uma coisa dinâmica. Que vocês brincando com a realidade, né. Você médio representam o que aconteçam com a realidade." Deus sabe tudo mas não é X-9. 00.11.16-00.11.34 
successful funk musician, visiting the Morrinho model. This recognition and attention by Brazilian celebrities is only a portion of what opportunities the original Morrinho group has had.

There are several points in the God Knows Everything But He's Not A Snitch where there is no dialogue, but successive quick jump cuts showing the youth learning to work as cameramen and to edit film, giving television interviews, and showing their work at art exhibits in cities around Brazil. Thais Araujo, an acclaimed Brazilian actress, appeared and traveled with them to be on the national variety show Domingão do Faustão with O Rappa, one of Brazil's most well-known hip hop groups. On this show the Morrinho youth were able to find the donors to finance their trip to Barcelona. This scene, less than half way through the film, showed a group of anxious youth who seem to be uncertain that they would be able to travel abroad. At the end of the documentary, the viewer sees the original group of Morrinho youth three years older and much more experienced at showing their artwork, now at the Venice Biennale, a major international contemporary art exhibition.

Artwork. Cilan and Maiquinho spoke of a total of three photos that represented opportunity for work for them. Cilan thought it was important to give recognition to some of their sponsors that are shown in Photo 121. Maiquinho spoke of Photos 202 and 203. "This is showing here that everything that we are able to create at Morrinho, because of Morrinho, and pass on to the world. Sell our images on various kinds of objects, CDs, bags, dolls, it’s very cool." ${ }^{, 104}$

\footnotetext{
104 “Está mostrando aqui tudo o que a gente consegue criar dentro do Morrinho, através do Morrinho, e passar para o mundo, não é? Vender as nossas imagens em vários tipos de objetos, CDs, bolsas, bonecos, bem legal."
} 
In giving a general description of Morrinho, fifteen participants described it as a game turned refuge and eleven participants described Morrinho as an unlikely but valued source of work and travel. The organization was also described as a social project.

A social project. Throughout my time volunteering with Morrinho and living in Pereira da Silva, many have termed Morrinho's original goal as being a social project for the boys of the community. While the project started as a game, which at times served as a refuge from the surrounding violence, nearly all of the participants told me that Morrinho later grew into a social project as it reached out to a broader population of local boys (i.e., Betinho, Budé, Cilan, Criistian, Felipe, Maiquinho, Junior, Luciano, Nicolas, Paulo Vitor, Pedro, Rafael, Rani, Renato, Rodrigo).

Interviews. Maiquinho talked to me of the social role that Morrinho played in the lives of youth from Pereira da Silva. In normative-evaluative terms, Maiquinho communicated how a youth development project can serve an important social role in modeling how to act in a professional setting. He talked about how Morrinho has been a vehicle through which youth have been able to change demonstrations of their social class. Finally, Maiquinho communicated that youth who participate in social projects can adapt to a number of social situation and this can be largely instrumental in who they grow up to be.

Morrinho is this, always rescuing kids, making them stay there. Sometimes from time, sometimes from doing silly things, from being idle at home. Sometimes inside of Morrinho, they feel a bit better, you're distracted there, you learn more there.... I can say that 40 percent of what I have today, I can say that Morrinho helped me a lot. Not only with my financial situation, but with experience. 
Sometimes it took me from a bad path, making sure that I didn't make bad choices.... Morrinho made me think more about life... I learned a bit about education, I met people who were a lot more civilized. At the time, we were young and we spoke with slang, with an accent, slang from the favela, and sometimes lacking education. ${ }^{105}$

Junior elaborated on this social aspect of Morrinho.

The social part is something that we were doing, a thing that, Project Morrinho started more for this, no? In order to get kids who were in the comunidade with nothing to do, take them from idleness, who could be attracted to another path. We were bringing them here, to get to know other things, to see videos, to become acquainted with theater. ${ }^{106}$

Rafael also explained this part of Morrinho to me in some detail.

Morrinho is a 'weapon' to try to take away a bit of the mundaneness from the kids. But the project takes a bit of what is found here and turns it into something else, a game. Because here it's a violent game, because we have weapons and we portray this. But here you can do what you want. My character can kill as many as he wants. Here a kid can spill out the anger that he may feel for somebody.

\footnotetext{
105 "O Morrinho é isso. Sempre... Sempre resgatando crianças, fazendo ficar ali dentro." "É. Às vezes, do tempo, da bobeira, de ficar a toa em casa. Às vezes, dentro do Morrinho, você se sente um pouco melhor, você está se distraindo ali, você ali aprende mais... Posso dizer que $40 \%$ de tudo que tenho hoje, posso dizer que Morrinho me ajudou bastante." "Não digo só em situação financeira, mas também na experiência, sabe? Da vida... Às vezes, ter me tirado do caminho errado, evitado que eu me envolvesse com alguma outra coisa que não fosse certa.... O Morrinho me fez pensar melhor na vida... aprendi um pouco do lado da educação, conheci pessoas bem mais civilizadas, na época. A gente pequeno, às vezes, com uma gíria, com um sotaque, uma gíria de favela, às vezes, uma falta de educação."

106 “A parte social é a parte que a gente estava fazendo, uma coisa que, o Projeto Morrinho surgiu mais para isso, não é? Para agregar as crianças que estavam na comunidade sem fazer nada, de bobeira, podendo estar indo para outro caminho. A gente estava trazendo eles para cá, para brincar aqui, conhecer outras coisas, levando para conhecer, para ver vídeo, para conhecer teatro."
} 
It's a place where he can express himself as he wants, it's a place you express yourself. ${ }^{107}$

In my member checking email with Cilan, he said that he sees Morrinho more like a school that brings positive influences to those who participate. "We are a type of school that tries to bring opportunities for change... we are a reference for the positive side.... Morrinho is a school of life."108

Film. The positioning of Morrinho as a social project happens at various points of God Knows Everything But He's Not A Snitch where Fabio and Markão ask the youth to reflect on their experiences with Morrinho. Early in the film they talked to Maiquinho and Paulo Vitor about what they think their lives would have been without Morrinho. Both express their dislike for how the traffickers commonly recruit youth with their socioeconomic profiles, and the boys talk about their own work ethic. As Maiquinho spoke there was footage of him very young, under the age of 10 . We then see him several years later, in his adolescence talking about how he began working at the age of 11 to help support his family. This setting symbolized the impressionable age at which many of the youth started with Morrinho, and the well-adjusted young adults they became through the social experience of Morrinho. As adults, the Morrinho participants have jobs, have almost entirely stayed out of the drug trade, and their experience with

\footnotetext{
107 “O Morrinho é uma arma para tentar tirar um pouco o cotidiano das crianças. Mas ele tira em uma parte e aqui de dentro se põe em outra, como brincadeira. Porque aqui tem uma brincadeira violenta, porque tem armas e toda essa retratação. Mas aqui dentro a gente pode fazer o que que a gente quiser. Meu personagem pode matar quantos eles quiser. Aqui os meninos podem extravasar a raiva que ele possa sentir de alguém, é o lugar ontem ele pode se expressar como quiser, um lugar para se expressar."

108 "Somos um tipo de escolar que tenta trazer uma oportunidade de mudança.... Somos uma referencia para do lado positivo.... O Morrinho é uma escolar da vida."
} 
Morrinho has given them an education with which to better understand their position in society. This last point will be discussed more thoroughly in Chapter 6.

A bit later in the God Knows Everything But He's Not A Snitch Renato was interviewed. He likened playing at Morrinho to being a type of therapy for the participants when they were younger and Pereira da Silva was experiencing more violence. "When Morrinho started, it was more of a therapy to keep people away from wrong doings but it kind of hid our reality behind that role playing. We'd disguise what we saw in our daily life here in our community." As he says this, the screen is split showing him talking on one side, and the boys playing at and creating the model favelas on the other side. This set up seems to communicate the social aspect that Morrinho played in the development of the youth.

Artwork. Addressing Photo 26, Cilan talked about the teamwork that has gone into building Morrinho into what it is today. "The sign, it's talking about the people that contributed and helped the Project. Whoever is there will have to read this and understand." Rafael talked about Photo 68, a common scene for the participants to talk about. It is a memorial built to two former Morrinho youth who lost their lives too soon. The blue sign that Rafael refers to reads, "To hurt a brother is to injure your own hand. We are all part of the power of creation!"109 Rafael talked about the teamwork that has gone into making Morrinho what it is.

Sixty-eight, it has a message in the corner in blue, that is really strong and communicated what God wants for all people, unity. This is what God looks for the most at Morrinho, unity. Why? Because Morrinho is not made of a small

\footnotetext{
109 “Ferir um irmão é ferir a própria mão. Todos nós fazemos parte da poder da criação!”
} 
group of people, it can be maintained with a few people, but it depends on the situation. $^{110}$

Rodrigo talked of Photos 46, which included the same blue sign that Rafael talked about above. "Rio de Janeiro, Sugar Loaf and the names of Max and Shrek, who are two people we miss a lot, Shrek and Max, two people who are with us." ${ }^{\prime 11}$ Later Rodrigo, looking at Photo 120, talked to me about how Morrinho is a project that takes joint effort and that the final project is impressive.

I think all of the models [of the favelas] are marvelous.... There are some people that do some things better than others and others do other things better, and this is good for us at Morrinho. Because when we get together for an exhibit, each person does what they do best and the exhibit turns out marvelous. ${ }^{112}$

Criistian talked about Photos 35 and 40 as sites where the entire Morrinho community came together to make improvements to the model when they were needed. About Photo 40, he said, "Morrinho had a time when it rained a lot, this bridge broke and we had a general meeting with all of the people that played to rebuild it." ${ }^{\prime 13}$ As was discussed in this section, the description of the organization as a game turned refuge, opportunity for

\footnotetext{
110 “A 68, ela tem uma mensagem, aqui no canto azul, que é um mensagem bem forte que retrata o que Deus quis para todas a pessoa: a união. É o que a gente mais procura no Morrinho: a união. Por que? Porque o Morrinho não é feito só de uma pessoas, ele pode se mantar com uma pessoas, mas depende da situação."

111 "O Rio de Janeiro, o pão de açúcar e o nome do Max e do Shrek, que foram duas saudades eternas, o Shrek e o Max, duas pessoas que estavam aqui com a gente."

112 "Acho que todos são maravilhosos.... Tem pessoas que fazem uma coisa melhor do que a outra, entendeu e outras pessoas fazem melhor do que os outros, e isso é bom para a gente do Morrinho. Porque quando a gente se reúne para fazer uma exposição, cada um faz o que mais sabe, e aí a exposição fica maravilhosa, entendeu?"

113 “O Morrinho teve um tempo em que choveu muito, essa ponte quebrou e tudo e a gente fez uma reunião geral com todos os que brincavam para reformar ele todo."
} 
work and travel, and a social project gave the participants various ways in which to build a positive personal identity, which will be discussed in the next section.

\section{Character Development}

One of the early plans for Morrinho was to have a formal NFE program with a classroom and a budget for supplies. I witnessed first hand that over the years a number of grants and donors were promised to the Morrinho group, however none of them amounted to successfully starting an educational branch. Nonetheless, in my interviews with the participants it became clear that through their participation with Morrinho, they received the benefits of developing self-esteem and personal identity, which are goals of NFE. In turn, they created a program structure to help boys younger than them. In their interviews with me, nearly all of the participants talked about the opportunities they were afforded as being a part of Morrinho and that the project shows the accomplishments that a group of youth from a favela can achieve if given the right opportunities for growth. This opportunity for disenfranchised youth is the goal of much NFE in Brazil (Gohn, 1999; Neate and Platt, 2010; Simson, Park, \& Fernandes, 2001b; Truet, 2001; Zaluar, 1994).

Recognized as artists. Many of the participants talked to me about Morrinho as a work of art (i.e., Cilan, Felipe, Junior, Luciano, Maiquinho, Rafael, Rani, Renato). They also talked to me about the potential for creativity that can exist among a group of youth from a favela.

Interviews. Talking directly of possibilities, Rani talked of creativity, imagination, and the length at which one can go with these traits. In normativeevaluative terms, Rani recognized the value that art has in a society, and that being 
recognized for a valuable profession can raise a person's self-esteem and can make a person feel more accepted in society. As was described earlier, Rani expressed that a formal education can increase a person's life chances, but expressed frustration over the immense challenges that he had to surmount in order to graduate. He communicated that through his experiences with Morrinho, he was able to achieve his goals without any formal artistic training. "I think our message is this, that you don't need, that all you need is creativity, we don't need to study. People come here and say 'Whoa! How did those guys do that?" Well, man, it's creativity. It's a gift. We never studied to know how to do this. It's what came to our imagination, and we created it, we made it." ${ }^{, 14}$

Renato explained how a prominent message of Morrinho is about the power of creativity, and that formal training is not always necessary to be recognized for artistic talent and creativity. "We don't see ourselves as artists exactly. But I think it communicates that artists can come from anywhere. They can be from a favela, they can be from a dump, they can be from an apartment, they can come from anywhere."115

Luciano talked about how the group's evolution to artists was hard won. He told me that a lot of people see their work, and think that it is pretty, but they don't recognize the hard work that goes into the exhibits. Visitors to the exhibits outside of Pereira da Silva also do not realize, or always appreciate the improbable beginnings of Morrinho. "People may think it's easy, but it's not. It's something that you have to like to do, with

\footnotetext{
114 "Eu acho que a mensagem é o seguinte, é que não precisa, basta ter a criatividade, não precisa estudar para gente. As pessoas chegam e falam 'Pô, como é que os caras fizeram isso?". Pô, cara, a criatividade.... É um dom. A gente nunca estudou para fazer isso, a gente... o que vier na imaginação, a gente vai criando, vai fazendo."

115 "Nós não vemos como artistas, certo? Mas eu acho que comunica que um artista pode sair de qualquer lugar. Pode ser de uma favela, pode ser de um lixão, pode ser de um apartamento, pode ser de qualquer lugar."
} 
desire, for the comunidade. It's an artistic work actually. We started it as a game, but today you can see that it's much more than an artistic work."

Cilan seemed very confident of the artistic nature of the Morrinho model in Pereira da Silva, and the exhibits outside of the favela. He described Morrinho as a richly communicative work of art. Talking of the general population that sees Morrinho, Cilan said, "They understand that it is art. That it's a work of art, a large installation, rich with information, sayings, phrases, evolution, that portrays the reality of favelas with bricks, and recycled materials. It's a simple way of depicting life."

Film. Morrinho's transformation from a child's game to a work of art is a central message of God Knows Everything But He's Not A Snitch. At the beginning of the documentary, as Morrinho is being introduced as a game, Cilan said, "Each one created something. People say I'm creative, but I say I don't work alone. I work with my friends. I'm creative, but he was creative enough to make a team. Out of a small piece of wood. He's good at it. It's art.",118

Approximately 10 minutes after Cilan described Morrinho as art, the entire original group is shown preparing for their first exhibit showing Morrinho as art in a department store window in a mall in the middle and upper class area of Rio called Barra. Once they are finished with the installation, visitors marveled open-mouthed and smiling.

\footnotetext{
116 "Mesmo que seja, como eles acham que seja, fácil, mas não é, não. É uma coisa que você faz com prazer, com vontade, pela comunidade. É um trabalho artístico, no caso. A gente fez como uma brincadeira, mas, hoje em dia, você vê que é muito maior do que muito trabalho artístico."

117 "Entende que é uma obra de arte. Uma obra de arte, uma instalação grande, rica em informações, dizeres, frases, evolução, que retrata a realidade da favela com tijolos, materiais reciclados. Uma forma simples de retratar a vida."

118 “'Cada um inventou uma coisa, depois falavam 'Pô você tem criatividade'. Depois eu falo, 'Não sou só eu. Foi eu e meus amigos.' Porque eu tenho criatividade, eles tem criatividade, faz um equipe. E foi mais madeira, pô da um jeito, da uma arte.” Deus sabe tudo mas não é X-9 00.06.42-00.06.58
} 
They received a number of compliments. One woman, identified as Vilma Pereira, a psychologist, said, “They didn't look for anything sophisticated. They've got everything from their own environment. That's what's important. They're born architects. A Godgiven talent." ${ }^{\prime 19}$ Soon after this, Denise Mattar, acclaimed Brazilian art curator, is seen visiting the Morrinho model in Pereira da Silva. Then the Morrinho group is seen speaking with Márcia Jardim, art curator, about how to build an exhibit in the Parque Ruinas in the Santa Teresa neighborhood of Rio de Janeiro. An unidentified male who saw the Morrinho exhibit at Parque Ruinas spoke of its artistic components.

When I saw Morrinho it was clear why I think it's art. Even if they didn't create it for that purpose, the scale model is a space for thinking inside the comunidade itself about how it is to live in that comunidade. It's a space for thinking, and it's not architecture in itself but it has artistic aspects. When we see it from the distance it's pretty. Actually, it's beautiful. Art can be pretty and ugly, but this is beautiful art because it calls for thought. Everybody is touched after seeing Morrinho. It's impossible not to see it as art. ${ }^{120}$

Toward the end of the documentary, Cilan sat down to chat with Denise Mattar and with Robert Storr, American art curator and director of the 2007 Venice Biennale and Dean of the Yale School of Art. Cilan asked if Dean Storr believed that they had represented the favelas in some aspect. Dean Storr said,

\footnotetext{
119 "Não buscaram nada sofisticado, tiraram do próprio convívio dele, n'é. Eu acho que isso é que foi importante. O dom de Deus mesmo.” Deus sabe tudo mas não é X-9. 00.19.06-00.19.19

120 "Quando eu vi o Morrinho, pra mim foi evidente, por isso acho que é arte, que mesmo que eles não criaram como isso como objetivo, o Morrinho é uma maquete, é um espaço com reflexão dentro da comunidade, sobre como é viver naquela comunidade. E ser um espaço de reflexão, isso aqui não é uma arquitetura em se, mas aqui tem aspectos artísticos mesmo você olha de longe é bonito. É bonito não, é belo. Que a arte pode ser bonito e feio mas aquilo ali é belo, chama reflexão. Ninguém sai dali depois de ver Morrinho. Então é impossível ver que não é art.” Deus sabe tudo mas não é X-9. 00.29.45-00.30.48
} 
I think in a way yet one can't represent a favela really, it exists in a way different here than it does when it's in Rio, because all art is about imagination. It's what people take from this and then what they do with it. That's why it's here as a work of art really. It is, it's a work of the imagination and you create it, you imagined it, and now people come and they use their imaginations and people with good imaginations will know what to make of it. ${ }^{121}$

A few minutes after Dean Storr's remarks, the Morrinho group learned that a near fullpage photo of their exhibit was featured on the front page of the Venice edition of Corriere della Serra, one of Italy's oldest and most reputable newspapers.

In the closing scenes of the documentary, unidentified voices of the Morrinho group reflected. One voice said "We've never dreamt of being in the Venice Biennale which is for artists only. It's the World Cup of the arts." ${ }^{122}$ Another voice said,

In Venice, we found out that we're really artists. We didn't think of ourselves as artists. On previous trips everybody said we're artists, but we didn't agree with them. I thought that being an artist was way above us. We didn't study to become artists. We never took formal classes. It was just play, and we became artists. ${ }^{123}$ Artwork. Felipe spoke of Photo 37 as showing Morrinho as a colorful work of art. As he talked about this photo he told me about the amount of maintenance and care

\footnotetext{
${ }^{121}$ Deus sabe tudo mas não é X-9. 01.11.35-01.12.25

122 “A Bienal de Veneza a gente não esperava, que é um negocio só de artistas do, a Copa do Mundo de artistas. A gente não esperava estar lá.” Deus sabe tudo mas não é X-9. 01.14.45-01.14.57

123 "Em Veneza a gente descobriu que a gente somos artistas mesmo. Que a gente não se considerava artistas nas outros viagens assim. A gente falava 'Ah, vocês são artistas,' não sei que. A gente, não, a gente, eu acho artista muito, é uma coisa muito acima de nós, assim que não estudou pra isso, não fizemos cursos. Então a gente fez uma brincadeira e se transformou em artistas." Deus sabe tudo mas não é X-9. $01.14 .45-01.15 .23$
} 
that must go into keeping the model in optimal artistic form. "The models in the background came out very colorful, the Brazilian flag, I think this photo is very pretty.... I like to show Morrinho where it's pretty. Colorful, clean, no fallen leaves. Because if it's not perfectly maintained, it's not as impressive. Just look at this photo, what a pretty photo, everything is colorful."124

Describing Photo 151, Luciano spoke of Morrinho as very pretty, as an example of why tourists have been visiting the model for such a long time, and of the tourism company that supports the project. "It shows the model as being pretty, well located and everything, and 'Project Morrinho 14 years'. And the tourism company that we partner with when we do tours. It's a great photo, very pretty.",125

Renato spoke of Photo 26 and Rodrigo spoke of Photo 21 each as being the vision that people first see when they enter the space of the model. Renato described the view as commonly the first place that visitors begin to show their admiration of the work for its artistic value. "Everybody comes here and stands with there mouths agape. This is the view of amazement." ${ }^{\prime 26}$ Speaking of Photo 21, Rodrigo spoke of a look of amazement that visitors to the model get when they first see view it from this vantage point. "It's the entrance to Morrinho. It's the first impact of whoever has never seen it comes here and looks from there. It's a look of amazement. It's the look that people get when they are

\footnotetext{
124 "Saiu o colorido das maquetes que estão ao fundo, a bandeira do Brasil, achei muito bonita essa foto.... eu gosto de mostrar o Morrinho do jeito que ele fica mais bonito, entendeu? Com cor, limpo, sem folha, entendeu? Porque se ele não estiver com a manutenção perfeita, ele não chama tanta atenção. Olha aqui essa foto, que foto bonita, tudo colorido."

125 "Mostra a maquete bonita, bem localizada tal e Projeto Morrinho, 14 anos. E a companhia de turismo, que é o que a gente faz quando o pessoal vem fazer turismo, é uma grande foto, muito bonita."

126 “Todo mundo chega ali e fica de boca aberta. Essa é a visão do espanto."
} 
seeing Morrinho for the first time." ${ }^{, 127}$ Eight of the participants discussed the recognition as artists that Morrinho made possible for them. Several of them linked this recognition to an increased in their self-esteem.

Increased self-esteem. One of the principle goals of NFE programs that work with marginalized youth is to build up their self-worth so they will make healthy life decisions. Five of the participants talked about how Morrinho helped them to create a more positive self-image and to believe in their own potential (i.e., Cilan, Felipe, Junior, Pedro, Rani).

Interviews. Cilan talked about how his experience with Morrinho changed him from a young kid with a lot to learn to a recognized artist. He expressed pride in this transformation. "I arrived here a kid, I didn't know a thing. I didn't have any idea of what art was, a work of art, architecture, visual arts, nothing like this. These days I've earned a name. I had to change my name to an artist's name. I have to change my profession from delivery guy to... earn the name of a visual artist." 128

Felipe used an expression to which Perlman (2011) devoted a chapter. He said that Morrinho made him be gente, a person. Perlman (2011) analyzed this term to be used in Brazilian Portuguese when somebody is part of incorporated society. Felipe described Morrinho as a project that provided him with a lot of positive experiences, which led to an increase in self worth.

\footnotetext{
127 "Porque é a entrada do Morrinho. É o primeiro impacto de quem nunca viu quando chega aqui e olha dali, sabe? Ela olha assim e já dá aquele baque. É o rosto, a fisionomia de quem vê o morrinho pela primeira vez é aquela."

128 “Cheguei aqui moleque, não sabia de porra nenhuma. Não tinha noção do era arte, obra de arte, arquitetura, artes plásticas, nada disso. Hoje em dia, eu ganhei um nome. Tive que mudar o nome para um nome artístico, tive que mudar minha profissão de entregador de quentinha... ganhar um nome de artista plástico."
} 
I owe a lot of what I have to Morrinho. Morrinho is a thing that I'm sure will never leave me. I like this project a lot. I am certain that the best sensations that I felt were when I was participating at Morrinho, working for Morrinho. When I felt more like gente, 'I can, I will be able to.' When I most recognized my own value was when I was working for Morrinho. ${ }^{129}$

Later in his interview, Felipe explained to me the type of experiences he had with Morrinho that taught him to respect himself more. He also described how he confronts difficult situations as a result of his experiences with Morrinho. In normative-evaluative terms, Felipe described the socioeconomic divisions of Rio de Janeiro, youth development organizations can play an important role in working to include disenfranchised as members of society. Speaking of the professional artistic collaborators that Morrinho worked with, Felipe said,

They did everything to build us up. I was thinking that it would be just the opposite, that they were going to be like, 'Oh, look at them, those poor kids from a comunidade.' But more than anything it was almost like they idolized us. That was when I felt more like gente, where I really felt like I mattered. I thought, 'Whoa, I have value, a lot of people like what I do.' So, today I look at everybody straight in the eye, I don't drop my head. They can have more money than me, they can have a car, they can have a motorcycle... they can have money, the can have a pretty woman, they can have everything, but they didn't have the life experience that I had. They didn't experience what I did. They didn't have

\footnotetext{
129 "Devo muito da minha ao Morrinho. O Morrinho é uma coisa que eu tenho certeza que nunca vai sair de mim, eu gosto muito desse projeto. Porque eu tenho certeza que as melhores sensações que eu senti foi quando eu estava agindo com o Morrinho, trabalhando pelo Morrinho. Quando eu me senti mais como gente, 'Eu posso, eu consigo.' Quando eu mais reconheci o meu valor, foi trabalhando pelo Morrinho."
} 
the happiness that I had to cross the ocean. That gave me very high selfesteem. $^{130}$

Junior also explained how Morrinho was a great experience for him and gave him opportunities that he would never have had otherwise. He learned and grew a lot from these experiences.

I learned to value more what I have and what I had. I learned with Morrinho, I had a lot of good experiences. When we were in Berlin we were invited by the owner of one of the best restaurants of Berlin to eat lunch and dinner there. When we entered, there was an enormous poster of us at the entrance of the restaurant. The table was very large, and it was reserved, written on it was 'Project Morrinho.' When we sat down at the table and looked around, there were only elegant people, people with class. Everybody got up to ask for our autographs. It was something inexplicable, something very difficult to happen to anyone. And that didn't just happen once. It happened a lot of times. In Venice too... I'll never forget this. We were invited to dinner by the second richest guy in Germany. It was something that surprised me when the people stood up and started to clap for us. I looked around wondering if it was really for us. ${ }^{131}$

\footnotetext{
130 “O pessoal fazia de tudo para colocar a gente lá em cima, entendeu? Eu pensava ao contrário, que eles iam querer se sentir 'o cara' e olhar, 'Olha lá, os coitadinhos da comunidade.' Mas que nada eles queriam idolatrar a gente, ali foi onde eu me senti pessoa mesmo, eu falei, 'Caramba, eu tenho valor, muita gente gosta do trabalho que eu faço', entendeu? Aí, hoje em dia, eu olho para cada um, eu olho reto, não abaixo a minha cabeça. Pode ter mais dinheiro que eu, pode ter carro, pode ter moto... tem dinheiro, tem mulher bonita, tem tudo, mas não teve a experiência de vida que eu tive, não passou pelo o que eu passei. Não teve a felicidade que eu tive de atravessar esse oceano, entendeu? Me deu uma autoestima muito grande."

131 “Aprendi a dar mais valor ao que eu tenho e ao que eu tive. Aprendi que com o Morrinho eu conheci muita coisa boa. A gente foi convidado, logo quando a gente chegou em Berlim, um dos melhores restaurantes de Berlim, o dono convidou agente para almoçar e jantar lá. Quando a gente entrou assim, tinha um pôster enorme nosso na entrada do restaurante. A mesa era muito grande, reservada, escrito
} 
Film. The God Knows Everything But He's Not A Snitch shows many instances where the Morrinho youth can see that their work is valued nationally and internationally. Within the first 15 minutes of the film, the boys are viewing their own work in a centerfold spread in National Geographic Brazil. They also met and are aided by a number of nationally and internationally recognized actors, musicians, and artists. They exhibited their work nationally and internationally over a dozen times. Arguably the clearest recognition of the value of self-worth are Cilan's words in the documentary's final scenes. "From now on, I need to learn to respect myself. To respect myself, and have a sense of self-worth. I have something with this group that is only the beginning. There are still many things ahead of us." ${ }^{, 132}$

Artwork. Five of the participants talked to me of the inspirational phrases that are written at various places in the model. Cilan spoke to me of a Bob Marley quote that is depicted in Photo 80. The quote says, "We should not cry about something that was taken from us, but, yes, love what we have been given. Because what is really ours is never gone forever." ${ }^{\prime 133}$ Speaking of this quote, Cilan spoke of the importance of

\footnotetext{
Projeto Morrinho. Quando a gente sentava na mesa e olhava para o lado, era só gente granfinha, gente de classe. Todo mundo levantou para pedir autógrafo para a gente. Foi uma coisa inexplicável, muito difícil de acontecer com qualquer um. E não aconteceu uma vez só, aconteceram várias vezes. Em Veneza também.... isso eu nunca vou esquecer, a gente foi convidado para ir jantar, era o segundo cara mais rico da Alemanha. É uma coisa que eu me surpreendi, quando as pessoas levantaram e começaram a aplaudir a gente assim. Fiquei até olhando para trás, será que é para a gente mesmo?"

132 "Eu acho que agora tenho que aprender a dar valor, me respeitar. Em primeiro lugar me respeitar, e me dar valor. E acho que criei uma coisa com essa galera que acho que isso é só a começa. Ainda tem muita coisa pra acontecer." 01.15.52-01.16.08

${ }^{133}$ The quote at the model is roughly translated into Portuguese as, "Não devemos chorar por aquilo que nos foi tirado, mas sim amar aquilo que nos foi dado!!! Pois o que é nosso sempre volta e nunca se vai."
} 
persistence and fighting for what you believe in. "It's the phrase in the photo that gives incentive for victory. Incentive to fight... it's an example for life."134

Broadened cultural comprehension. Several of the participants talked to me of their experiences with Morrinho widening their understanding of cultural norms outside of their social class in Rio de Janeiro (i.e., Junior, Luciano, Rafael, Rani, Rodrigo, Paulo Vitor). For some of the participants, this cultural comprehension also included understanding what life is like in countries other than Brazil.

Interviews. Rodrigo explained to me that before he began participating at Morrinho he only ever frequented locations in favelas and talked to people from favelas. Through his experience with Morrinho, he learned to code switch between the cultural norms of favelas and the cultural norms of the asfalto. Speaking of how his cultural understanding has developed, Rodrigo said to me,

If you had arrived at the beginning of Morrinho, I wouldn't be talking with you, I don't know if it would be out of fear or out of embarrassment or fear of not being able to talk. I am certain that if there was a video camera and a laptop with someone from the comunidade or from another comunidade, I would be talking normally, but not with you. This is the kind of education that Morrinho gave me... These days I have more friends from the asfalto than from here. ${ }^{135}$

\footnotetext{
134 “A frase dele é incentivo de vitória. Incentivo de concelho para lutar... exemplo de vida."

135 "Se você chegasse no início do Morrinho, eu não estaria conversando com você, não sei se por medo ou por vergonha ou com medo de não conseguir falar. Eu tenho certeza de que, se isso fosse no início, a gente não estaria conversando. E eu tenho certeza de que se fosse uma câmera, um laptop com alguém da comunidade ou de outra comunidade, eu estaria conversando normalmente, mas não com você. Isso é uma forma de educação que o Morrinho me deu.... Hoje em dia eu tenho mais amigos lá embaixo do que aqui em cima"
} 
Paulo Vitor talked to me about the distrust he used to have for people from the asfalto. He told me that not only were he and the other Morrinho participants victims of discrimination because of where they lived, but they themselves were discriminatory towards those who did live in a favela. Fabio Gavião, one of the filmmakers who worked with the youth, emphasized the commonness that people from all walks of life share, and this made an impression on Paulo Vitor.

If you were from the asfalto, we from the morro have a bit of prejudice against people from there. They are like that with us too. I think that this started breaking down over time. Even Gavião himself, he always told us this, "No, you have to stop with this. Those who live on the asfalto, it's all the same thing. One person has financial resources and one doesn't, but it's the same thing." We used to be more closed-minded. ${ }^{136}$

Luciano also talked to me about the social modeling to which they were exposed through experiences with Morrinho. As a result, Luciano communicated that he feels like he can code switch to adapt to any cultural or social situation.

It helped a lot. It helped because in addition to us dealing with people who were more educated, people who are used to dealing with different kinds of people, they would say to us, 'It's like this guys'.... We learned to get along with people from other classes. It was a great experience.... These days, I can go any place, I

\footnotetext{
136 "Se nasce do asfalto, a gente do morro tinha um pouco de preconceito com as pessoas de lá. Eles também tem com a gente daqui. Acho que isso foi sendo quebrado com o tempo. Até o Gavião mesmo, ele sempre falava isso, 'Não. Tem que parar com esse negócio. Quem mora lá embaixo é tudo a mesma coisa. Um tem uma boa condição e outro não tem, mas é a mesma coisa.' A gente era mais fechado.”
} 
can speak with anybody and nobody even says anything about me living in a comunidade. It was a great thing to learn. ${ }^{137}$

Junior also talked to me about learning how to act in different social situations through his experiences with Morrinho. Junior told me that this was done through modeling of speech and behavior by the people that they worked with who were not from favelas.

The educational part was before when we played here, we didn't know how to talk to people, we didn't know how to deal with people. And these days, any one of us from the project acts well in any location. We know how to deal with people, with the public. We know how to talk, when to use slang and where to use it, and when not to use it, we know where we can't speak it. This was a big thing that we learned here. Here we speak in slang, cursing and everything. But for example, when we were in Europe, in some places we acted, we spoke with people more formally. We started to learn this, something that some years before, when we only played, we didn't know how to do this. ${ }^{138}$

In subjective terms, Junior said that Morrinho has an educational component, which has helped him a lot. In normative-evaluative terms, Junior communicated that increased

\footnotetext{
137 “Ajudou muito. Ajudou, porque além de a gente se comportar como pessoas educadas, pessoas que aceitam conviver com outras pessoas, eles chegavam e falar: 'É assim, rapaziada'.... Tanto que a gente aprendeu a conviver a pessoas de outras classes. Então, foi uma grande experiência.... Hoje em dia, eu ando em qualquer lugar, falo com qualquer pessoa e ninguém nem fala que eu moro na comunidade. Foi um grande aprendizado."

138 "Educacional foi a parte que, antigamente, quando a gente brincava aqui, não sabia falar com as pessoas, não sabia lidar com as pessoas. E hoje em dia, qualquer um de nós do projeto se comporta bem em todos os locais. Sabe lidar com todas as pessoas, com o público. Sabe falar, quando tem que usar gíria, sabe aonde tem que falar, quando não tem que falar, sabe aonde não pode falar. Isso foi uma coisa que a gente aprendeu aqui. Aqui, a gente fala gíria, xinga e tudo. Mas quando, por exemplo, a gente estava na Europa, em alguns lugares a gente se comportava, falava com as pessoas formalmente. A gente começou a aprender isso, coisa que há alguns anos atrás, quando a gente só brincava, a gente não sabia como era isso.”
} 
educational value can be found when youth are interested in what they are doing and that code switching is a valuable skill to supersede a person's social class.

Film. A central message of God Knows Everything But He's Not A Snitch is how Morrinho expanded the cultural norms of the participants. The film begins positioning the original group as creative youth from a favela. Soon they are working showing their game as a work of art. Over the course of the filming, the participants travelled nationally to Natal, Recife, Campo Grande, and São Paulo. They traveled internationally to Barcelona, Paris, Munich and Venice.

When the original group returned from Barcelona, after participating in the UNHabitat World Urban Forum, their parents are interviewed on their reflections of the experience. Sandra, Paulo Vitor's mother, explained in detail the variety of valuable cultural experiences that the original group had through their experiences with Morrinho. A trip like that for the son of someone poor, is already wonderful. And to participate in a Forum like that is very important for us, mothers, who raise their kids in a comunidade in need. We can't give much. As you see, my house is being fixed. We work everyday, and we achieve this happiness of having our kid among a group like that. And one of the boys is a cousin, another is the son of a friend who went to school with me, who is Sesi, Cilan's mom. I'm really very excited. I'm very happy. ${ }^{139}$

\footnotetext{
139 "Só um viagem como esse por o filho de alguém pobre já é um presente maravilhoso. E para participar na convenção assim é importantíssimo pra a gente, as mães, que criam os fillhos na comunidade carente pode dar muito pouco, n'é. Como podem ver minha casa está em obra, nós trabalhamos no dia a dia. E você consegue ter uma felicidade dessas, tem o seu filho junto com um grupo desses, os meninos um é primo, outro é filha de uma menina que foi criada comigo, estudou comigo, que é a Sesi, a mãe de Nelcirlan. Estou realmente muito emocionada, muito feliz." Deus sabe tudo mas não é X-9. 00.37.1700.37 .48
} 
Six of the participants described the broadening of cultural understanding that was made possible through their experience with Morrinho. Another way in which the organization developed a positive self identity in the participants is the role-modeling which was made available to them.

Positive role-modeling. Many of the participants talked to me about how their experiences with Morrinho changed their attitude toward a lot in their immediate surroundings (i.e., Budé, Cilan, Criistian, Junior, Nicolas). Through their experiences with Morrinho, these participants said that they have been able to lead a more positive life and have been able to avoid the negative influences of Pereira da Silva.

Interviews. Nicolas explained to me how the people at Morrinho, and the experiences with them, create a positive example of how to live. In normative-evaluative terms, Nicolas explained that youth development programs can provide a supportive environment to help youth be calmer and happier individuals. There are negative social influences in favelas, but youth development programs can work against the negative influences.

It's like an education. People come here with a bit of a violent education. We try to give an education to them. We explain how it is. Because, there are going to be a lot of people who are not going to want to teach you, they are going to want to break you down, to make and example out of you, they are not going to want to help you. But not here, here we are like a family. ${ }^{140}$

\footnotetext{
140 "Vamos botar como uma educação. A pessoa chega aqui e tem uma educação muito violenta. Assim, nós vamos tentar dar uma educação para eles. Explicar como é que é. Porque lá muitas pessoas não vão querer te ensinar, vão querer te bater, te dar o exemplo, não vai querer te ajudar. Então aqui não, aqui a gente é como uma família."
} 
Criistian communicated to me what several of the other younger boys said, that Morrinho allowed them to mature to be a calmer person.

I think I changed my way of being. I am calmer. I am totally calm, but before I wasn't like this. I used to be kind of agitated, very agitated, I stressed out about anything. I think that after I started to come here, I started to be calmer, my mind evolved. My friends helped me. They told me what to do, they would always talk with me. ${ }^{141}$

Similarly, Budé told me that he has changed his values over the course of his participation with Morrinho to focus more on peace and reject violence. "I think more about peace, but seeing as there is a lot of violence out there in the world, I look to the world to see my life better, to learn... to study, to graduate, to work." ${ }^{142}$

Film. Throughout God Knows Everything But He's Not A Snitch, the original Morrinho group is shown working in coordination with numerous successful public figures: Brazilian musicians Carlinhos Brown, DJ Marlboro, Fernanda Abreu, O Rappa, and MV Bill; Brazilian actress Thais Araujo; and art curator Denise Mattar. They were featured on Domingão de Faustão. The then current Minister of Culture and Brazilian musician Gilberto Gil was also shown visiting and admiring their work in Munich. Super model Naomi Campbell admired their work in Venice.

\footnotetext{
141 "Eu acho que eu mudei o meu estilo de ser. Eu sou tranquilo, sou totalmente tranquilo, mas antes eu não era assim. Eu era muito fervoroso, muito fervoroso, me estressava à toa. Acho que depois que eu comecei a vir para cá, eu comecei a ficar mas tranquilo, minha mente foi evoluindo. Meus amigos aqui que me aconselharam. Falaram para eu fazer isso ou aquilo, sempre conversaram comigo."

142 "Penso mais na paz, mas como tem muita violência aí no mundo, olhar para o mundo com um olhar melhor de vida, de aprender... estudar, acabar o estudo, trabalhar."
} 
Cilan reflected on how he has changed his actions over the course of his participation with Morrinho.

As a kid who lives in a comunidade you don't have to think you're going to be on the wrong side. You can do that at any time. It's your choice. But I didn't want that. It was my decision. I won't lie. I'm honest. I've been there. I went through this experience. I'm not the best person to give advice to someone on this path but I can be an example that this is not the right path it's not good for you. It's the one-minute fame, like the Big Brother show. You're famous for one month, then you get nothing. ${ }^{143}$

This section has focused on what Morrinho is for the participants and what kind of character development their participation created. The next section will address what Morrinho is for outsiders who see the film and the artwork.

\section{What Morrinho Communicates}

As the Morrinho group has shown their film and art to people outside of favelas, and outside of Brazil, they have intended to carry a message about what they believe living in a favela is like. They do not completely reject the dominant societal perceptions of trafficking and violence. The Morrinho participants say that this is a part of living in a favela. However, there is more to favelas. Everyday people can live their lives in favelas without the daily presence of violence. They believe that Morrinho is a different vision

\footnotetext{
143 "Eu penso como um garoto que mora na comunidade que você não precisa achar, que você vai pular de errado. Você pode ir de qualquer momento. É uma escolha minha, mas eu criei isso já pelo ir pelo isso caminho, entendeu. Foi decisão minha. Eu escolhi não ir. Mas assim, não vou mentir, sabe que eu sou sincero. Já passei pelo caminho errado, vi como que é a experiência. Eu não sou a pessoa melhor pra dar conselho pra quem está em esse caminho, mas eu posso mostrar pelo menos um exemplo de que não é o caminho certo. Não é o bom pra você. Acho que é fama, tudo bem. É a fama de um minuto, como fosse Big Brother. Você tem fama durante um mês e essa fama não via levar nada." Deus sabe tudo mas não é X-9 $00.54 .15-00-00.54 .57$
} 
of the dominant message of society because they advocate for more societal acceptance, and because Morrinho is an example of the art and culture that exists within Rio de Janeiro's favelas.

\section{Nuanced Messages of Life in a Favela}

The Morrinho participants wish to communicate to others what it is like living in a favela through their art at Morrinho. This message does not completely reject the dominant vision of trafficking and violence. That exists in real life, so it is represented at Morrinho. But violence and trafficking is not all that Rio's favelas should be known for. The participants aim to communicate a more nuanced vision by showing the business and social services that exist in a favela, and by showing what life is like for an honest working resident. This message was also addressed in the literature (Goldstein, 2003; Neate \& Platt, 2010; Perlman, 2010).

Violence and trafficking. The game that is played at Morrinho does not shy from the topic of violence and trafficking that exists within the favelas. The participants said that they act out reality as they see it, and violence and trafficking is part of that reality (i.e., Cilan Criistian, Gão, Junior, Luciano, Maiquinho, Nicolas, Paulo Vitor, Pedro, Rani, Rafael, Renato, Rodrigo).

Interviews. By describing Morrinho as a role-playing game (RPG), Maiquinho emphasized that the game is very lifelike. He talked about the dolls at Morrinho having a life like anyone else would, but also living in a reality where tragedy may be more likely to strike.

They live like us. I can't say 'Oh, this doll is going to do this today.' I don't know. He could die tomorrow, he could die right now, a car could hit him. It's 
his life. It's like an RPG game... a doll dies and he is not reborn. The truth is that a doll at Morrinho has his life, so he lives his day, really, like me and like you. He goes to sleep, he wakes up, he eats, he drinks, he tries to earn a buck, he falls in love. Just like us. It's the reality of all of the comunidades. ${ }^{144}$ Junior explained TV Morrinho Live, a combination of artwork and scripted theater performed to a live audience. According to Junior, TV Morrinho Live showed a violent side of the favelas, but that is because the day-to-day reality of Pereira da Silva and Rio's other communities used to be very violent, and at times still is. He talked about the restriction of movement in and around the community that traffickers would enforce on residents.

We reproduce the everyday of the comunidade. So, not so much these days, but before the everyday of all of the comunidade was trafficking, that was what predominated in the comunidades. So we reproduced what we lived. Until today we reproduce this, because in a way it has diminished a lot, but it's something that still happens in some comunidades.... You can't do some things because of the trafficking. You can't leave until a certain hour, you can come back at dawn, because all of a sudden there could be a shootout, police on the morro when you are entering. So we reproduce this... the everyday violence in Rio de Janeiro. ${ }^{145}$

\footnotetext{
144 “Eles vivem como a gente. Eu não poso dizer, 'Ah, esse boneco vai fazer isso hoje.' Eu não sei. Ele pode morrer amanhã, ele pode morrer agora, pode passar um carro e atropelar ele. É uma vida. É tipo um jogo de RPG... o boneco que morre, não nasce de novo. A verdade é que o bonequinho dentro do Morrinho tem uma vida, então, ele vive um cotidiano, na verdade igual ao meu, igual ao seu. Dormir, acordar, comer, beber, correr atrás de dinheiro, trabalho, namorar. É igualzinho a gente, sabe? É a realidade de todas as comunidades."

145 “A gente reproduz o cotidiano da comunidade. Então hoje em dia não mas, antigamente o cotidiano de todas as comunidades era o tráfico, era o que predominava nas comunidades. Então, a gente reproduzia o que a gente via. Até hoje, a gente reproduz isso, porque de certa forma, diminuiu muito, mas é uma coisa
} 
Luciano's explanation of why violence and trafficking is the predominant scene at Morrinho is similar to Junior's explanation. Only, Luciano focused on the violence and trafficking still being a reality for many of Rio's favela residents. He also talked about demonstration of material wealth, and the alternative balance of power that is portrayed at the scenes of Morrinho.

Day-to-day scenes are portrayed, which are scenes of violence that happens in the comunidades of Rio de Janeiro, which are shown on TV. They are scenes of family, scenes of power, power of organized crime, of material power, like cars and motorcycles, and the unity of the comunidade, we show this a lot at Morrinho. ${ }^{146}$

Rafael further explained the focus of the game on social issues that relate to life in a favela. The game and scenes portrayed tend to be violent, because favela residents may easily see the police staking out the area, the sale of drugs, or presence of armed guards at the favela entrance.

A lot of times we live with drug trafficking. Not directly, you are going up and down the street, and you pass the point of sale for the drugs or by the lookout how is security for the point of sale. And there are also the police, going down to the street you could be approached by the police, they could be coming up the street.

\footnotetext{
que ainda acontece em algumas comunidades.... Você se limita a algumas coisas por causa do tráfico de drogas. Você não pode sair até certa hora, você não pode voltar de madrugada porque, de repente, pode estar tendo tiroteio, polícia no morro, você entrando. Então, é isso que a gente reproduz aqui na comunidade, invasão de uma comunidade na outra, o cotidiano da violência no Rio de Janeiro, é isso que a gente reproduz."

146 "São retratas as cenas do dia-a-dia, que são as cenas de violência que acontecem dentro das comunidades do Rio de Janeiro, que são mostradas na televisão. São mostradas as cenas de família, cenas de poder, poder paralelo, cenas de poder matérias, tipo carro e moto, e também a união da comunidade, a gente demonstra muito dentro da maquete."
} 
All of this is part of the comunidade. There doesn't exist a comunidade in Rio de Janeiro or São Paulo where this doesn’t exist. Because wherever drug trafficking is present, the police come to repress it. There are the residents, and the police don't know who are residents and who are the traffickers. ${ }^{147}$

I asked Pedro to elaborate on what the everyday of a favela resident might be, and he talked about the violence that could be a daily possibility for residents. In normativeevaluative terms, art and play can be expressive forms to demonstrate what a person's lived situation is. He also said that there does not only exist violence in the favelas, but the violence is notable because of the social consequences and the macro-level factors. It's a depiction.... In real life there are not shootouts all day long. And here where Morrinho was more actively showing war, there were shootouts everyday. But then there was a funk dance, the owner of the house fighting over there, his children. Meanwhile a helicopter leaving to get a criminal on the other side. ${ }^{148}$

Film. The scenes of play and that were acted out that are included in God Knows Everything But He's Not A Snitch often interweave the reality of the favela with scenes of violence and trafficking. Within a minute of the film starting, there are scenes of Lego dolls with large automatic weapons and the voice of Rodrigo explains the drug dealers

\footnotetext{
147 "Muitas das vezes a gente está vivendo com o tráfico de drogas. Não diretamente, você descendo e subindo na rua, você vai passar ou pela boca de fumo ou por um plantão que está fazendo a segurança daquela boca de fumo. E também com a polícia, você saindo pra rua você pode ser abordado pela polícia, ela pode estar subindo na sua rua. Tudo isso faz parte de todas as comunidades. Não tem comunidades no Rio de Janeiro ou em São Paulo que não passe por isso. Porque onde se estabelece o tráfico de drogas a polícia vai reprimir. Tem um morador, e a polícia não sabe quem é morador ou quem é traficante.”

148 “É um retrato.... E na vida real não é toda hora que se tem tiroteio. E aqui quando o Morrinho estava na ativa era guerra mesmo, tinha tiroteio todo dia. Ali o baile funk rolando ali, dona de casa brigando ali, os filhos. Enquanto isso helicóptero saía para pegar um bandido ali do outro lado.”
} 
violently kill snitches in the favela, and that the youth aim to represent as true to form as possible this violence. Cilan and Rodrigo explained,

C: "We burn the Lego pieces."

R: "We throw alcohol and throw it away."

C: "We burn them till they melt, screaming and firing the guns.",

The next few scenes show in detail the violence that is acted out at the model as one of the drug trafficking Lego dolls dies in a car accident resulting from a police chase. A few minutes later there is a shootout and hand-to-hand combat between well-armed drug trafficking Lego dolls. The dialogue between the dolls mentions the point of sale of drugs in a neighboring community.

Later, half way through the film after the original group has made their first trip to Europe, the play at the model seems to have evolved. The play now shows a Lego doll interviewing on camera another Lego doll about the death of an infamous Lego trafficker named Alex. We learn that Alex died when "he tried to escape from police when he got in a tunnel near Mineira to deliver drugs."150 For nearly a minute the next several scenes show the cocaine that was exchanged, as represented as domino pieces, the scene of Alex's death, and the trafficker's reaction of burning cars in the asfalto when they learn of Alex's death at the hands of the police.

The darker daily reality can be for someone who lives in a favela is communicated by visitors from around the world who saw the Morrinho exhibit in the

\footnotetext{
149 “A gente queima as peças de Lego." "E joga álcool e joga fora." “Queima até a derretimento, gritando e disparando as armas." Deus sabe tudo mas não é X-9. 00.01.25-00.01.27.

150 "Ele tentou fazer uma fuga da policia e entrou no túnel perto da Mineira para entregar drogas lá." Deus sabe tudo mas não é X-9. 00.42.45-00.42.56
} 
2007 Venice Biennale. Three visitors seem to understand the trafficking and violence that exists in the favelas as communicated by Morrinho's art. One man says in Portuguese, "I like the way it's being presented. It has a bit of irony. It talks of something very serious but in a very disguised and light way. It liked it. I loved it."151 Another man says in English, "I thought it was entertaining, funny, but in the midst of you being entertained, and it being funny, it gets, it suddenly dawns on you. It's a little dark, you know. So it's like why am I laughing at this." ${ }^{\text {152 }}$ A man who identifies himself as Argentinean says in English,

This one to me is ah, it's beautiful, and it's horrible because this is an extreme work of art, but it also shows an extreme place where people actually live. And these extreme places I know about the culture, I really appreciate their music and that I just wish for them that they didn't have such a dangerous life. And that this is the best way to use some time in the Biennale not to present just an abstract idea or something without opinion, it is to present something which is actually making people remember that not everybody lived in a palace and that not everybody has welfare to fall back on if something goes wrong in life. ${ }^{153}$ Artwork. Nicolas primarily positioned Morrinho as a game and an opportunity for travel, but he also talked of scenes of violence and trafficking. He spoke of a scene depicted in Photo N12 where the Lego characters were selling drugs. He also showed me

\footnotetext{
151 "Gostei da maneira que foi apresentada, por ter uma certa ironia. Da fala de algo muito critico mas de uma forma bem disfarçado, assim bem light. Gostei. Adorei." Deus sabe tudo mas não é X-9. 01.10.4501.11 .10

${ }^{152}$ Deus sabe tudo mas não é X-9. 01.01.10-01.11.24.

${ }^{153}$ Deus sabe tudo mas não é X-9. 01.12.25-01.13.20.
} 
Photos N13, N14, and N15 indicating that they were photos of the best guns because "it shows the most details on the fusils, the details make it very pretty." ${ }^{154}$ The violence that is portrayed at Morrinho includes acting out shoots outs, drug sales, and car chases. Thirteen of the seventeen participants said that this depiction of violence is shown at Morrinho; however, this is not all Morrinho demonstrates. Morrinho says that there is much more than violence and trafficking in Rio's favelas.

Favela life is multi-faceted. While the violence and trafficking is a prominent part of the game at Morrinho, many of the participants also emphasized to me that that is not all that is portrayed at Morrinho (i.e., Betinho, Budé, Cilan, Felipe, Gão, Junior, Luciano, Nicolas, Paulo Vitor, Pedro, Rafael, Rani, Renato, Rodrigo). They wish so communicate that there is much more to living in a favela than violence and illegal activities. Honest people also live work in Rio's favelas.

Interviews. Nicolas talked to me about how Morrinho showed in a true fashion what it is like to live in a favela. There are people living their everyday life, but there is also a lot of portrayal of the presence of traffickers and police.

"What happens in real life. So we take a little bit of real life and we bring it here. Police and criminals, and what do they try to do? Enter the favelas and stop the trafficking. But it's not just this. In real life what is there? There's hospitals, there's a city hall. Everything that you could imagine in real life, we bring here. Everything. Everything that is in real life, we try to bring a bit of it here."155

\footnotetext{
154 "É porque ele vai detalhando os fuzis, vai detalhando e vai deixando muito bonito."

155 “O que acontece na vida real, então a gente pega um pouco da vida real e traz para cá. Polícia e bandido, então polícia tenta fazer o que? Entrar nas favelas e acabar com o tráfico. Então é assim, não é só isso. Na
} 
Felipe talked about the holistic message of favelas that Morrinho communicates. There exist scenes that deal with everyday issues, but the scenes acted out do not avoid the presence of trafficker and police violence that has historically been present in Rio's favelas.

It doesn't escape from reality much. There's going to be violence, there's going to be drugs, there's going to be guns, but there are also good stories. It's not only violence and shootouts and war. There are dances, there are parties, there's this too. It doesn't escape reality much. What happens in the comunidade, happens at Morrinho too. ${ }^{156}$

Renato told me of the message that he wished others to understand when they view Morrinho's artwork or film. He admitted that there exists trafficking in the favelas, but emphasized that favela residents care for their families, earn a living, and enjoy their spare time like anybody else.

I want them to understand that a comunidade doesn't only have drug trafficking, it doesn't only have shootouts between the police and the criminals. There are the residents too, there are parties, there are funk dances, which at times are not put

vida real tem o quê? Tem hospital, tem prefeitura. Tudo o que você imagina na vida real a gente traz para cá, tudo. Tudo que está na vida real a gente tenta trazer um tanto para cá."

156 “não foge muito da realidade não. Vai ter violência, vai ter droga, vai ter arma, mas também vão ter histórias boas. Não vai ser só violência, troca de tiro e guerra, não. Vai ter baile, vão ter festas, também vai ter isso. Ele não foge muito da realidade não. O que acontece na comunidade... O que acontece na comunidade, acontece no Morrinho também." 
on by the traffickers. Sometimes the people from the comunidade get together and put one on. ${ }^{157}$

Rafael expressed a desire for people to understand the positive life events that happen in a favela. Living in a favela is not only the negativity of violence, trafficking, and alternative rule of law that is the dominant vision broadcast by the media.

In the comunidade there is not only violence, drug trafficking. In the comunidade there exist people who are capable of specializing in other avenues, other cultures, other lifestyles. Because drug trafficking is not the only way to make a living in the comunidade.... The cool things about showing this is that in the comunidade there exist good people, but there exist bad people too. ${ }^{158}$

Film. More than halfway through God Knows Everything But He's Not A Snitch, Junior talked of the experience of Morrinho making a pilot series for the children's network Nickelodeon. He talked about the positive and the negative of living in a favela. In normative-evaluative terms, Junior said that no matter what the social class of a person, there can still exist a level of normalization in their life. He also communicated that the dominant vision of the favelas is not the most comprehensive, and there exist complexities to the understanding of social class.

I think it was a bit complicated, because Morrinho, play at Morrinho is a bit violent. Because that's the comunidade's reality. Sure, we have the residents,

\footnotetext{
157 “Eu quero que elas entendam que uma comunidade não tem só tráfico de drogas, não tem só tiroteio de polícia com bandido. Tem morador também, tem festa, tem baile funk, que as vezes não é beneficiado pelo tráfico, as vezes o pessoal da comunidade se une para fazer aquilo."

158 "Na comunidade não existe só as questões da violência, do tráfico de drogas. Na comunidade existem pessoas que tem capacidade de se aprofundarem em outros meios, outras culturas, outras vidas. Porque não existe só o tráfico de drogas para sustentar a comunidade.... O legal de se mostrar é isso, na comunidade existem pessoas boas, mas existem pessoas ruins também."
} 
there's always peace but in the comunidade we often face violence. Morrinho shows the comunidade's reality, not what people want from us. There isn't only happiness here, we have sadness too. We have to show it all, the good and the bad stuff. But it was a very nice work to do. A bit complicated, but I'm glad it worked out. ${ }^{159}$

Artwork. Cilan and Gão used Photos 52 and 54 to talk about the presence of the BOPE in the favelas. Speaking of Photo 52, Cilan emphasized the problems that the BOPE creates in the lives of favela residents.

It's for them to understand that it's one of the special police forces of Rio de Janeiro. The famous and special police that are compared with the American SWAT, only it is a lot more violent because they work in the favelas and not in the asfalto.... Talking with the BOPE is to cause problems in your life. You don't talk to the BOPE, you don't even make friends with the BOPE. It's just to show that there exist police within this space. ${ }^{160}$

Speaking of Photo 54 Gão explained the BOPE to be a controversial force in the favelas, but they enter as a result to an increased presence of trafficking. Gão was less critical of the BOPE than Cilan.

\footnotetext{
159 "Eu acho que foi um pouco complicado, porque, o Morrrinho, assim, a brincadeira é meio violenta. Que é a realidade da comunidade então. Tem os moradores, sempre tem a paz, mas na comunidade, a gente vive, a gente se da, assim, com a violência. Então, no Morrinho a gente mostra que é a realidade da comunidade, não o que os outros querem do morro. O morro não é só felicidade, tem as tristezas também, então a gente tem que mostrar tudo. Não só a parte boa, também a parte ruim. Mas foi um trabalho muito bom. Meio complicado, mas muito bom de fazer.” Deus sabe tudo mas não é X-9 00.58.03-00.58.52

160 “É para eles entenderem que é uma das polícias especiais do Rio de Janeiro. As polícias especiais, famosas, que é comparada com a SWAT americana, só que um termo muito mais violento porque eles trabalham em favelas e não em asfalto.... Conversar com o BOPE é trazer problema para a sua vida. Não conversa com o BOPE, não se faz nem amizade com o BOPE. É mais para mostrar que tem a polícia dentro do espaço."
} 
The BOPE tried to organize the city, it doesn't go into the favela. Like, they are only called when things get heated up. If you include that photo, you can explain that the BOPE keeps the favela under control and everything. When the traffickers are causing a disturbance, it's the BOPE that goes there and calms things down most of the time. ${ }^{161}$

Felipe spoke of Photo 30, which was of his model. He told me of the time he spent and the attention he paid to making sure that the incline of the bridge was life like and proportional to the size of the dolls at the model. He took pride in the life-like nature of his model.

This here is the street that I told you about that I did thinking, the incline here, look, I did this thinking as if it were reality. Here in the entrance, and you go up, here is the sports center. This here I did as if I were a doll myself. ${ }^{162}$

Fourteen participants described the duality of what is shown at Morrinho, violence and trafficking as well as a macro-level view of what like if like for residents not involved in the local crim. The next section will explore on the discussion that specifically addressed the activities of the working residents of a favela.

Daily life of residents. The participants further develop the reality living in a favela through their play by showing what it is like for an everyday resident to live (i.e., Cilan, Criistian, Junior, Maiquinho, Paulo Vitor, Pedro, Rafael, Rodrigo, Teibe).

\footnotetext{
161 "O BOPE tenta botar colocar organização na cidade, não vai na favela. Tipo assim, eles só são chamados quando a chapa esquenta, não é? Aí, você vai botar a foto lá, você vai poder explicar que o BOPE é que bota ordem na favela e tal. Os traficantes quando estão fazendo muita merda é o BOPE que vai lá e dá um jeito, na maioria das vezes."

162 "Essa aqui é a rua que eu te falei que eu fiz pensando, a subida aqui, olha. Eu fiz pensando como se fosse realidade. Aqui é a entrada dela, aí sobe, aqui tem uma quadra. Isso aqui eu fiz como se fosse um bonequinho mesmo."
} 
Interviews. I asked Pedro to elaborate on what the everyday of a favela resident might be, and he emphasized the everyday activities that anybody anywhere might experience being depicted at Morrinho. People work long hours and take care of their families. In subjective terms, Pedro communicated that Morrinho shows a complicated and holistic vision of life in a favela. Morrinho also carries a message of equality and disagrees with the dominant vision of favelas. In normative-evaluative terms, Pedro explained that in order to reach equality for all, it is important for there to exist dialogue that will promote class mobility and will combat prejudice and discrimination.

Morrinho is a portrayal of the comunidades of Rio de Janeiro. It's the day-to-day life of the people. A person waking up at five in the morning to go to work, children leaving at six in the morning to go to be at school by seven. A mother leaving to go to work, a father looking to feed his family. ${ }^{163}$

Teibe told me what he wants people to understand about Rio de Janeiro and Brazil in general. According to Teibe, the city and the country are not as violent as the media projects, and that people in the favelas live their normal lives without the constant threat of violence.

What is shown on TV is not everything that happens here in Rio de Janeiro, in Brazil. There are a lot of things that are shown on TV, that they put, they say that here in Brazil is very dangerous, that there's a lot of death here, that they rob

\footnotetext{
163 “O Morrinho é um retrato das comunidades do Rio de Janeiro. É o dia a dia das pessoas. O pessoal acordando cinco horas da manhã para poder ir trabalhar, as crianças saindo seis horas da manhã para estar no colégio as sete. Mãe saindo para trabalhar, pai para arrumar o pão de cada dia."
} 
people. It's not all that people say. And in the comunidade too, it's not all shootouts. There are comunidades where there is not drug trafficking. ${ }^{164}$

Film. There are scenes at the beginning of the documentary that show every day life in a favela. In the opening scenes when Project Morrinho is being introduced to the viewer as a child's game, Paulo Vitor, Cilan, Maiquinho, and Junior are sitting at the model speaking to the filmmakers explaining what kind of scenes they act out. They point to two dolls who are on a date, to the boss of the community who is resting at his home, and to two dolls having a friendly exchange in what looks like a social situation. In the next scene several scenes, they set up and activities of a funk dance at the model are shown. The scenes show cars and motorcycles arriving to the dance from different parts of the model to result in dozens of dolls dancing in front of huge speakers and in a red flashing light. The chatter of a crowd can be heard along with the funk music of Maiquinho singing. This section has focused on the scenes that Morrinho shows that may be included in the generally held perception of favelas. There exist violence and trafficking, but there also exist a duality where workers live, and there exist people who perform their daily life in favelas as anybody would perform anywhere. The next section will discuss how Morrinho pushed popular perception to change there what people may think of favelas, and it counters the dominant characterization.

\section{Countering the Dominant Characterization of Favelas}

Morrinho is also an alternative to what is the dominant societal perception of favelas. The participants believe that Morrinho shows that everyday people live their

\footnotetext{
164 “Tudo que aparece na televisão não é tudo que se passa aqui no Rio de Janeiro, no Brasil. Tem muita coisa que aparece na televisão, que eles colocam, falam que aqui no Brasil é muito perigoso, tem muita morte, que roubam pessoas. Não é isso tudo que eles falam. E nas comunidades também, não é tiroteio. Tem comunidades que não tem tráfico de drogas."
} 
normal lives in favelas without the constant presence of violence. The Morrinho group believes that their artwork advocates for more societal acceptance of favelas, and they believe that their work is a demonstration of the art and culture that exists within favelas.

Alternative version. The participants also talked to me about what they want people to understand about living in a favela when they see the Morrinho artwork or the films. One message is that living in a favela is not what is broadcast in the dominant messages of the media (i.e., Betinho, Cilan, Junior, Rafael, Renato, Rani, Teibe). As discussed above, Morrinho shows that people live their everyday lives in favelas. These people are just like anybody else.

Interviews. Rani talked about what he thinks foreign tourists and middle-class Brazilians might think when they see the Morrinho model for the first time, he referenced the negative images of favelas that are shown in television. In normative-evaluative terms, Rani communicated that the media perpetuates the false negative perceptions of favelas. However, the artwork of Morrinho is social justice oriented and works to counter the dominant vision of favelas, and this in turn works to stop the cycle of discrimination.

I think they imagine, because what happens is that there are people who have never come here, they've only seen it on television. Because a lot of things they show on television are of trafficking, and a lot of times they are from other countries... For them it's different, they come to see how we make a scale model look like a comunidade, what a favela looks like, and they have the opportunity to 
see it as if they were coming here, what there is in a favela. There are bars, there are traffickers, there are stairs, there are power lines, there's everything. ${ }^{165}$

Artwork. Speaking of Photo 1 and Photo 2, Cilan remarked on how while they show the signage of Morrinho, they also show parts of Pereira da Silva. He described the scenes as pretty.

The signs for the project. It's a cool photo, it shows a little bit of the favela. I think that it will give people and idea of what it's like... Photo 2 also, it shows more or less where the entrance of the project is, at least where it's located, a bit of the location, of the area, plus the signs. ${ }^{166}$

In selecting Photos 39 and 42, Rafael communicated that it is important to show how expansive the model is and what Pereira da Silva looks like.

39 , it shows the model, it's something cool for people to see too. Because there is the model and there is the installation surrounding it. We represent Project Morrinho, but also the things surrounding it, the comunidade, our installation. 42 too, the representation of the houses that there are surrounding Morrinho. ${ }^{167}$

\footnotetext{
165 "Eu acho que as pessoas ficam, assim, imaginando. Porque o que acontece, tem pessoas lá que nunca vieram aqui, só veem pela televisão, entendeu? Porque passam muita coisa só de televisão, de tráfico e eles, muitas vezes lá fora.... Para eles é diferente, eles vão ver, a gente faz a maquete do jeito que é uma comunidade, do jeito que é uma favela, e eles tem a oportunidade de ver como se eles tivessem vindo aqui. O que que tem numa favela. Tem bar, tem os traficantes, tem as escadas, tem fios de luz, tem tudo."
166 “A marca do projeto. Uma foto legal, mostra um pouco o que é a favela. Acho que quem tiver noção vai entender o que é. Acho que é isso. Não tem muita coisa para mostrar não. A foto 2 também, mostra mais ou menos onde é a entra do projeto, aliás, aonde fica situado. Um pouco da localidade, da área, mais uma placa de sinalização."

167 “A 39. Ela mostra a maquete. É uma coisa legal das pessoas verem também. Porque tem a maquete e tem a instalação em volta. A gente representa o lugar do projeto Morrinho, mas também as coisas que tem em volta: a comunidade, nossa instalação. A 42 também é a mesmo coisa: a representação das casas que têm em volta ao Morrinho."
} 
The presence of the buildings and houses surrounding Morrinho give an idea of what the setting looks like and what the local living conditions are like. While seven participants talked to me about Morrinho showing an alternative version of the dominant characterization of life in a favela, a few participants focused on the positive examples of favelas that Morrinho demonstrates.

A positive example of favelas. Three participants talked about how Morrinho is a positive demonstration of the art and culture that can come from a favela (i.e., Betinho, Cilan, Rani).

Film. In God Knows Everything But He's Not A Snitch, as the Morrinho group was headed to their art exhibit in 2003 at Parque Ruinas in the Bohemian neighborhood of Santa Teresa in Rio de Janeiro, Fabio interviewed Cilan on what he hoped would happen with this exhibit. Cilan expressed a desire to show the creativity and expression that can come from favela residents, and he rejected a negative image. "I want to show our work, our creativity, our urban engineering from a favela... so people can see it and don't think that what happens in the comunidade has only bad influence. We'll show them that's not true."168

As Rani was walking through the streets of Paris in 2005, he reflected on the work that they had been doing there. Similar to Cilan, he talked about the positive cultural influences that exist in the favelas. He also expressed a desire to improve his living standards.

\footnotetext{
168 "Espero mostrar meu trabalho, nossa criatividade, nossa ingeriria urbana da favela... pode mostrar nosso trabalho que saiu de comunidade em outros lugares, vendo pensar coisas erradas, isso 'Ah tudo que acontece na comunidade só influencia de coisa erradas.' A gente vai mostrar aí para ver que não é o que o pessoal pensa." Deus sabe tudo mas não é X-9 00.28.39-00.29.15
} 
We want to continue to better ourselves and to show that people from favelas are not like they think in Brazil. Favelas also have their art and culture. They have good people who want to prosper. They want a chance, because many don't have a chance in life. ${ }^{169}$

Artwork. Speaking of Photo 199, Betinho talked of the positive aspects of favelas. He talked to me about how the image of Morrinho countered the largely negative portrayal of the favelas in the media. In normative-evaluative terms Betinho communicated that dialogue about social divides is important to work toward social justice and equality. Morrinho's artwork communicates this message.

The comunidades don't just speak about bad things, the talk about good things. The comunidades have projects like this, a lot of them.... This photo is not talking about trafficking and death. It's talking about good things that exist in a comunidade. That's why I like this photo, because on TV they only talk about death in the comunidades.... There doesn't just exist this in the comunidade, there are also good things. That's why I like this photo, I think it's pretty. ${ }^{170}$ Truth claims that were deduced about what Morrinho communicates reveal that favelas are not what the dominant characterization is, and that there exist positive demonstrations of art and culture in the favelas. Morrinho also advocates increased social acceptance.

\footnotetext{
169 “A gente quer crescer cada vez mais, entendeu. Mostrar que a gente da favela não é, não é como pensam no Brasil, entendeu. Favela também tem sua arte, sua cultura. Tem as pessoas de bem que querem subir na vida, entendeu. Ter a chance como muitas pessoas não tem chance na vida." Deus sabe tudo mas não é X-9 00.47.14-00.47.38

170 “As comunidades não falam só de coisa ruim, falam de coisa boa... As comunidades tem projetos também, bastante.... essa foto aqui não está só falando de tráfico, morte... Está falando de coisas boas que tem na comunidade. E por isso que eu gostei dessa foto aqui, porque na televisão só fala de morte nas comunidades.... Para falar que na comunidade não tem só isso, também tem coisas boas... Aí eu gostei dessa foto, achei bonita."
} 
Advocate more societal acceptance. Four of the participants also told me that the Morrinho artwork is symbolic of favela residents having the same treatment and life opportunities as those who do not live in favelas (i.e., Cilan, Luciano, Maiquinho, Teibe). Morrinho advocates for more societal acceptance of favelas and their residents.

Interviews. Luciano's description of what is communicated at Morrinho focused on the written phrases on the model. For him, the phrases communicate what life in a favela is like, and that they are in need of more support and societal acceptance, and less discrimination. In subjective terms, Luciano communicated that Morrinho's work is important in advocating for social acceptance of favelas. In normative-evaluative terms, he said that it will benefit the entire city if the most marginalized of favela residents are included as equal members of society.

The phrases, the great phrases that we put at Morrinho, they are very meaningful. They show what happens in the comunidade, we show this with the phrases. They are not phrases that apologize for anything, but they show what happens in the comunidade and what could be better. In the phrases, if you look, you'll know what the comunidade is lacking. It's needing more friendship, people that look toward the comunidade, because they don't have, it's difficult.... We live this and see this in the comunidade, so we put it in the favela that is Morrinho. ${ }^{171}$

\footnotetext{
171 "As frases, as grandes frases que a gente coloca dentro do Morrinho, elas são bem significativas. Mostram o que acontece dentro da comunidade, a gente explica com frases. Não são frases que fazem apologia a coisa nenhuma, mas mostram o que acontece dentro da comunidade e poderia melhorar. Na própria frase, se você for procurar, sabe o que a comunidade está precisando; está precisando de mais amizade, pessoas que olhem pela comunidade, porque não tem, é difícil.... A gente convive aqui e vê isso dentro da comunidade. Então, a gente expõe ali naquela favela que é o Morrinho.”
} 
Artwork. Cilan spoke of Photo 115, which is of the National Theater of Favelas that he built in his model. He believes that favelas should have the same access and ownership of culture that the asfalto has and that Morrinho advocates for societal equality.

Why is it that only the asfalto has a theater? Why do they build a theater in the asfalto and they don't put one in the, why can't the people of the favelas have a theater? Are we that different from the people that live in the asfalto? Are we that different from high society? Is it only high society that has theater? Only high society can have theater on the asfalto? Why can't a National Theater be on a morro? $?^{172}$

Maiquinho also spoke of the National Theater of Favelas in Photo 115. He said he liked the idea of having high culture in the favelas, because it would bring more attention to the areas. If people visited the favelas to attend a theater performance, they would see that favelas are not all violence and that favela residents live like everybody else. "It's a good idea... honestly, saying what a favela is like, it would be very cool. You go to a theater in order to know exactly what it's like in a favela.",173

Luciano looked at Photo 166, and told me that the model used to be his, then spoke of the message of peace that Morrinho communicates. Peace and equal treatment is what is needed for the favelas, and what Morrinho wants for the favelas.

\footnotetext{
172 "Porque só o asfalto tem que ter teatro? Por que se constrói teatro no asfalto e não se bota um teatro... Por que as pessoas das favelas não podem fazer teatro? Somos diferentes das pessoas que moram lá embaixo? Somos diferentes da alta sociedade? Só a alta sociedade faz teatro? Só a alta sociedade pode ter um teatro no asfalto? Por que o Teatro Nacional não pode ser dentro do morro? Quem impediu isso?"

173 "É boa ideia... na verdade, contanto como seria a favela, seria bem legal. Você entrar em um teatro para saber justamente como é dentro de uma favela."
} 
This model used to be mine. These days I don't even know who's it is, but it's very pretty and it has here 'Project Morrinho, Peace'. 'Project Morrinho is what simplifies our project. Peace is what every comunidade wants to have. They want peace, the right to come and go.... like the common society on the asfalto. Equal rights, equal treatment. People that pay taxes like everyone else... we are equal to any other person. There doesn't have to be this discrimination. We want to have peace in this comunidade. Project Morrinho, this is a very symbolic photo. ${ }^{174}$

\section{Summary}

In the discussion of Morrinho as an organization, the participants communicated that it has served the role of being a valuable youth organization that has worked to keep the participants our of traficking. Several scholars researched and wrote on the importance of such a role being filled for Rio's favela youth (Leeds, 2007; Neate \& Platt, 2010; Perlman, 2010). Morrinho as a game was so captivating for the participants that it served as a refuge from the local trafficking, violence, and idleness. For the older participants, Morrinho has allowed them to work and travel within Brazil, and internationally. The organization was also classified as a social project since it has continued to help younger males of Pereira da Silva. The character development that happened with Morrinho has worked to have the youth recognized as artists, increase their self worth, broaden their cultural understanding, and introduce them to positive role

\footnotetext{
174 “Essa maquete já foi minha um dia. Hoje em dia, nem sei de quem é, mas está muito bonita e tem aqui 'Projeto Morrinho, Paz'. Projeto Morrinho é o que simplifica o nosso projeto. Paz é o que toda a comunidade quer ter. Quer paz, o direito de ir e vir... como na sociedade comum, aí embaixo. Direitos iguais, abordagens iguais. Pessoas que pagam impostos como todo mundo... somos iguais perante qualquer pessoa. Não tem que ter essa discriminação. Queremos paz dentro da comunidade e é isso. Projeto Morrinho, uma foto bem simbólica."
} 
models. All of these effects are important results that a non-formal educational program would aim to produce (Gohn, 1999; Hoppers, 2006; Simson, Park, \& Fernandes, 2001a). Morrinho as a work of art also carries a message that advocates deeper understanding of what life is like to live in a Rio de Janeiro favela. Morrinho does not completely reject the violence and trafficking that is commonly held as the hegemonic force in the favelas. However, Morrinho as a work of art says that this is not all that the favelas are. People live their everyday life in favelas absent of violence. There exist positive examples of art and culture. For these reasons, Morrinho condemns the discrimination that favela residents face, and advocates for more acceptance in society. 


\section{CHAPTER VI}

\section{DISCUSSION AND RECOMMENDATIONS}

What are the experiences of living in a Rio de Janeiro favela that the Morrinho participants communicate through their film, artwork, and words? The purpose of this visual critical ethnography was to examine the Morrinho participants' experiences of living in a Rio de Janeiro favela. This chapter begins with a review of the study and answers the research question. This chapter concludes with limitations of the study, recommendations for practice and policy, and recommendations for further research.

\section{Review of the Study}

The residents of the favelas of Rio de Janeiro face a number of challenges. They are marginalized by living in centers of urban poverty and hubs for organized criminal activity, are subjected to violence by the traffickers and the police, and are oppressed by the government and dominant society (Arias \& Rodrigues, 2006; Neate \& Platt, 2010; Perlman, 2010). Favela residents are likely to face discrimination for their association with being from a favela that Perlman (2010) and DaMatta (1991) termed as denying residents personhood and equal participation in society. The employment discrimination holds many in poverty and prevents upward socioeconomic mobility (Leeds, 2007). The fact that most favela children attend public schools is also a factor that keeps them at a social and economic disadvantage in society (Ireland, 2007; Reiter, 2009).

Brazilian public schools are generally not regarded for their quality, and those who can afford to send their children to private schools. The national school system has near universal enrollment rates for first grade, but dropout rates are steep with nearly $50 \%$ leaving school by the age of 15 (Ireland, 2007). As a result, approximately a quarter 
of Brazilians are functionally literate, with skills that allow for critical thinking through reading (Ireland, 2007; Reiter, 2009). Other challenges that Brazilian public schools face are a shortage of building space for classes to meet, limited face time that teachers have with students, high rates of grade repetition, and high teacher burnout and absenteeism (Cardoso \& Verner, 2007; Gatti \& Barretto, 2009; Ireland, 2007; Reiter, 2009). Schools in favelas are commonly areas of contestation for gangs and drug trafficking (Abramovay \& Rua, 2002; Guimarães, 1998; Leeds, 2007; Zaluar, 1994).

There is a problem with the male youth of Rio's favelas being lured into participation with the criminal organizations when they are in middle adolescent years, the age that many are dropping out of school, but are still too young to legally join the workforce (Leeds, 2007; Neate \& Platt, 2010; Perlman, 2010). Several scholars have emphasized the need to build a positive identity in male favela youth in order to decrease their likelihood of negative behaviors (Leeds, 2007; Neate \& Platt, 2010; Perlman, 2010). Hip hop and funk music have been used in recent history in urban Brazil to communicate a local reality and build a positive identity for marginalized youth (Pardue, 2008; Yúdice, 2003). In Rio de Janeiro, hundreds of NFE programs work to build a positive identity for favela youth through the use of music, fine arts, and other demonstrations of culture. However there is little academic literature analyzing these programs. This study looked at the Morrinho organization, one arts based youth program in the Pereira da Silva favela of Rio de Janeiro.

This study took the form of a visual critical ethnography (Carspecken, 1996; Pink, 2006; Rose, 2001). Using a participant-observer model of data collection, my own observations of what life is like in Pereira da Silva, the feature-length documentary film 
of the Morrinho organization, and interviews with 17 of the organization's participants were analyzed as sources of data. The interviews addressed the issues of how the participants characterized life in the Pereira da Silva favela, their experiences with the Morrinho organization, and their interpretation of 206 documentary photos of the Morrinho artwork. The data was analyzed through a process of reconstructive horizon analysis which allowed me to develop objective, subjective and normative-evaluative truth claims about what the participants communicated. Objective claims are considered those claims to which all people have access. Subjective claims are the thoughts and feeling of a specific individual. Normative evaluative claims are the claims that express what is valued by society (Carspecken, 1996).

The results of the data analysis generally supported the findings in the literature in numerous ways, but also allowed for greater understanding of the situation. The findings were divided into four general categories: (a) societal placement as favela residents, (b) individual experiences of living in a favela, (c) Morrinho as an organization, and (d) what Morrinho communicates. Societal placement as favela residents includes societal exclusion as well as inclusion, societal placement as communicated through semantics, and social markers of identity. The individual experiences of the participants addressed many benefits and a few drawbacks regarding living in Pereira da Silva, experiences of discriminatory behavior, and the good and the bad of their time in school. Morrinho was characterized as a game turned refuge, an organization that allowed for opportunities of work and travel, a social project, and a source of youth character development. The messages that the participants believed that Morrinho communicated to others were that 
of a nuanced message of what it is like to live in a favela, and a message of the positives of living in a favela.

\section{Discussion of the Research Question}

This study aimed to answer one central research question: What are the experiences of living in a Rio de Janeiro favela that the Morrinho participants communicate through their film, artwork, and words? In order to answer this research question as was communicated in the Morrinho artwork, I first strived to understand how the participants characterized their own experiences of living in a favela. When describing their experiences of living in Pereira da Silva, there were more positive aspects than negative aspects. However there was discussion of the ways in which the favelas faced violence in the form of security threats by the organized crime and the physical force exhibited by the police. The participants also talked about violence against the favelas in terms of government policies that perpetuate marginality, and societal exclusion that reproduces the divided status quo.

The participants also described several forms of discrimination that they had experienced personally or had witnessed other favela residents experience. The discussion about discrimination was closely linked to others' preconceived perceptions of what favela residents are like. The discrimination also seemed to be fueled by the systemic violence and oppression of favelas by the organized crime, police, government and dominant society. Several participants told me of ways that they felt they circumvented discrimination by situational molding their demonstrations of personal identity to that generally accepted by the dominant society of Brazil. 
Countering of a negative view of favelas was demonstrated by the positive outlook that the participants had on the gradual improvements that are being made to most of Rio's favelas, and the several agreeable aspects of Pereira da Silva. The countering of a negative view of favelas was furthered by the Morrinho artwork. The artwork does not deny the social ills of organized crime and trafficking that exist in favelas, but it goes past this. The Morrinho artwork shows the daily life of residents from the participants perspectives, shows an alternative version of favelas than what is the dominant perception, and Morrinho's artwork was said to show a positive example of favelas. The participants were very descriptive of the positive internal character development that they experienced as a result of their involvement with Morrinho. These dominant truth claim are detailed with the purpose of more fully answering the research question. A discussion of the analysis is complemented by a review of the literature and macro-level theory is applied (Carspecken, 1996).

\section{Demonstration of Personal Identity for Favela Residents}

Bourdieu's (1977) theory of habitus was the basis of my research into the markers of personal identity that the participants say are most commonly demonstrated by favela residents. In a classed society, habitus holds that different classes will develop different tastes of societal symbolic resources such as art, fashion, and language. The taste in symbolic resources of the dominant class is taken as the most highly regarded cultural capital, and the demonstration of an alternative taste works to reproduce the status quo of class divisions (Bourdieu, 1977). Goldstein (2003) found support for the theory of habitus in her research on identity and coping among Rio de Janeiro favela residents. The participants of this study cited several markers of personal identity that are typical of 
a resident of a favela. Five participants told me that speech patterns and the use of slang was often a notable differences between a favela residents and someone who lives on the asfalto (i.e., Betinho, Criistian, Paulo Vitor, Rani, Rodrigo). In terms of normativeevaluative truth claims, these participants communicated that the manner of speaking that many favela residents feel comfortable with is often not found acceptable in the asfalto and can be used as a marker of differentiation. Paulo Vitor's observation supported Roth-Gordon's (2009) research that the media can work to popularize the slang used in the favelas.

In agreement with Bourdeiu's (1977) discussion of habitus, seven participants talked to me about certain brands and style of clothing being more popular with favela residents (i.e., Betinho, Criistian, Maiquinho, Nicolas, Paulo Vitor, Rafael, Rani). The participants supported the differentiation in taste reflecting a different socioeconomic status; however, there were also comments from several of the participants that differing tastes are not strictly delineated. Rafael possibly explained this point the clearest when he explained that mothers in both the favela and the asfalto will pass down to their children similar taste in clothing style, but different situations and socialization processes will lead to different outcome in how people of each class dress.

As a further demonstration of taste, three participants spoke specifically of hip hop and funk styles of music being most commonly associated with favela residents (i.e., Gão, Maiquinho, Rafael). Similar to the discussions of style of speech and clothing, Maiquinho was the clearest in expressing to me that while the favelas are known for hip hop and funk music, in the asfalto there also exists a level of interest in these two styles. Pardue (2008) found that hip hop artists in São Paulo used their music to communicate 
their social reality, and Yúdice (2003) made the point that funk music in Rio de Janeiro allows the space to deal with and confront social exclusion for the city's marginalized population. The growing popularity of these two style of music among all socioeconomic classes increases the chances of the lived social reality of favela residents being understood by a wider population of Brazil.

As discussed in a later section, the demonstration of a favela identity can lead to increased levels of discrimination by the general population and in the employment sector (Goldstein, 2003; Perlman, 2010). However, there have also been NFE programs that use these same demonstrations of culture to build a positive identity with which to confront a difficult place in society (Gohn, 1999; Simson, Fernandes, \& Park, 2001a; Zaluar 1984). Morrinho is one such organization that has allowed the participants of this study to dialogue about the violence in their lived situation, but also establish a message countering the negative perceptions of where they live.

\section{Violence in and against Favelas}

The topic of organized crime in Rio's favelas was researched extensively in the literature as a dominant political force and security concern for favela residents (Arias, 2004; Arias \& Rodriguez 2006; Neate \& Platt, 2010). This issue was posed as a top concern for six of the 17 participants who spoke of the difficulties that they believed that most favela residents faced (i.e., Cilan, Luciano, Maiquinho, Pedro, Rafael, Rani). The security challenges were the most commonly cited negative issued that the participants mentioned when talking about their own experiences of living in Pereira da Silva. Six participants talked to me about the trafficking that currently exists in Pereira da Silva (i.e., Budé, Felipe, Pedro, Rafael, Rani, Renato), and four participants cited a downside of 
living in Pereira da Silva as the violence that was once a dominant presence of the favela (i.e., Cilan, Luciano, Rani, Rodrigo). Analyzed for normative-evaluative truth claims, the security situation was such a grave concern that all of the participants had peers that ended up losing their lives in the violence.

Rio de Janeiro's police force has been heavily criticized for taking the position of rendering favela residents more powerless through means of humiliation and heightened levels of violence (Arias \& Rodriguez, 2006; Goldstein, 2003; Human Rights Watch, 2009; Leeds, 2007; Neate \& Platt, 2010). Five of the participants linked the violence and trafficking to the negative practices of the government (i.e., Criistian, Felipe, Gão, Maiquinho, Rodrigo). Association with drug trafficking by young males who live in a favelas can commonly lead to death either by the traffickers themselves or by the police. In terms of a normative-evaluative truth claim, the police violence and abuse of power is a serious security threat, and the targeting of favela male youth contributes to their unlikelihood to grow up to be healthy and productive members of society. The targeting by the police is part of a larger problem of the government practices commonly not working toward the development of the favelas.

The government of Rio de Janeiro has been noted as reinforcing the challenges to the city's favelas (Goldstein, 2003; Freire-Medeiros, 2009; Perlman, 2010). Several studies link the democratization process that Brazil experienced in the mid-1980s to the growth of the favelas in urban areas (Arias \& Rodriguez, 2006; Jaguaribe, 2009; Perlman, 2010; Roth-Gordon, 2009). When discussing their perceptions of living in Pereira da Silva, five participants also discussed how there is a lack of government investment leading to a lower standard of living (i.e., Cilan, Luciano, Maiquinho, Rani, Rodrigo). 
Rodrigo made the link between the government policies and the increased levels of violence that occurred in the favelas, and later spread to other parts of Rio de Janeiro. Maiquinho gave a detailed example of burden that favela residents much shoulder as a result of the reactive government policies. In normative-evaluative terms, these participants described how the discriminatory practices of the government worsened the security problems and marginalization for the favela residents.

The violence in the favelas perpetuated by the organized crime, the police practices, and the government policies has also worked to reinforce societal exclusion of favelas. DaMatta (1991) and Perlman (2010) both addressed the participation in society that is differentiated by those with cultural capital, persons or gente; and those who do not possess the cultural capital and are excluded from equal participation, individuals. Three participants of this study talked about the societal exclusion that favelas face (i.e., Felipe, Paulo Vitor, Rafael). Analyzed for normative-evaluative claims, these participants highlighted the deep social divisions that exist in Rio de Janeiro and the marginal status of the favelas. The negligence of the favelas in public discourse and practice is a result of the systemic historical and political power structure in Rio de Janeiro. Not only does there exist a heightened security risk in the favelas, there is also a symbolic violence acted upon them that establish and maintain a situation of what Bourdieu (1977) termed to be domination by the dominant classes.

This closeness to the presence of violence and trafficking leaves the participants of this study in a less powerful position in society, and leaves them in a position to be more likely targets of discriminatory practices. This lack of relative power is something that Rio de Janeiro's police have historically capitalized upon, and that the government 
has historically reinforced through practice and policy. Freire (2009) wrote about dehumanization being an inescapable reality of humanity's struggle for humanization. This policy and practice of dehumanization perpetuates the imbalance of power between the general population and the favela residents (Freire, 2009).

\section{Discrimination for Favelas and Their Residents}

The taste demonstrated by favela residents can work to create perceptions of their class, and can lead to discrimination in the asfalto. Interpersonal discriminatory practices and job discrimination was discussed in the literature as being reinforced by the marginalization from larger society (Neate \& Plat, 2010; Leeds, 2007; Perlman, 2010). On a personal level in their real lives, the participants told me of four forms of discrimination that they felt as a basis of living in a favela. Six participants cited that being considered a trafficker or a criminal is a common reason for discriminatory practices (i.e., Cilan, Luciano, Maiquinho, Pedro, Renato, Teibe). This echoes what Undersecretary for Human Rights for the State of Rio de Janeiro Paulo Baia said, that the word favelado has become synonymous being a criminal, and hence gives a strong negative association to those who live in a favela (Neate \& Platt, 2010). In normativeevaluative terms, the participants gave reason to disapprove of this criminal activity, because the association perpetuates discrimination against favela residents. While the trafficking and criminal behavior is something that a small percentage of people partake in, all favela residents must deal with the burden of this negative association. The overgeneralizations and misperceptions of what life is like for most favela residents increase the level of discrimination that they face and negatively impacts the their experiences with dealing with the general population. 
Perlman (2010) researched the forms of discrimination experienced by favela residents and wrote how the combined factors of a person's class, including clothing, speech, body language, created an overall image of the person. This combined image works as a demonstration of a person's social class (Bourdieu, 1977), and bears consequence on how residents of the general population will judge a person from a favela. Six of the participants talked about facing stigmatization for being perceived as some of Rio's most impoverished residents (i.e., Criistian, Felipe, Junior, Paulo Vitor, Renato). In normative-evaluative terms, the lifelong discrimination based on a misconception is a heavy burden that restricts the life chances of a favela resident. This discrimination should not exist, but it does and it makes equal participation in society more difficult.

Discrimination based on race in Brazil has been widely researched. Perlman (2010) found that for the older generation in her longitudinal study, living in a favela was the most common form of discrimination, and race-based discrimination was second. However, for the grandchildren in Perlman's study, discrimination for living in a favela was reported as the most common source of discrimination, the second form was the general appearance of a person, and third was race-based discrimination. Reiter (2004) found that Black Brazilians were more than twice as likely as Whites to be living in poverty. Racism was cited as a form of discrimination by six of the participants (i.e., Budé, Betinho, Cilan, Criistian, Felipe, Maiquinho). In normative-evaluative terms, there exists race-based discrimination in Rio de Janeiro which leaves darker-skinned Brazilians at a disadvantage. 
Employment discrimination for favela residents was also reported in previous studies. Leeds (2007) reported that while all favela residents have difficulties finding work, the challenge is more pronounced for favela adolescents. As a result many residents write down fake addresses that will not identify them as living in a favela. Neate and Platt (2010) wrote about there being a sense among many favela adolescents that their chances of finding work are low. Rani was the only participant who talked to me at length about having difficulties finding work as a result of workplace discrimination, but his words were supported by other residents of Pereira da Silva, and his experience was closely aligned with the literature researched for this study. Rani's words revealed a great sense of frustration that he felt about the discriminatory practices that were leading to lost financial opportunities for him and his peers. Analyzed for normative-evaluative claims, this practice further perpetuates the class divides and increases the likelihood of cyclical poverty for many favela residences. Employment discriminatory practices coupled with interpersonal discrimination and structural marginalization work as violence against the favelas and their residents (Bourdieu, 1977; Freire, 2009).

\section{Countering Discrimination in Action and in Discourse}

Nearly all of the participants of this study spoke with me about some form of discrimination. However, coupled with the discussion of the discrimination, several of the participants brought up the ways that they minimize the likelihood that they are discriminated against (i.e., Felipe, Gão, Maiquinho, Nicolas, Rodrigo). Acting polite, smelling good, and dressing well were ways that these participants aimed to avoid discrimination. In terms of normative-evaluative claims, while prejudice in Rio de Janeiro is commonplace, these participants find ways to get around it. Perlman (2010) 
reported that 84 percent of her respondents perceived discrimination based on their appearance, and many of the young men and women spent a large portion or all of their income on items that would make them appear wealthier. This act is part of Bourdieu's (1991) description of a class struggle for power. This struggle of favela young people to avoid discrimination is a way for them to gain acceptance into society and begin to act in their own interests.

In addition to taking actions to avoid discrimination and assert a positive selfidentity, all of the participants talked to me of their own positive views of living in a favela. This contributed to a counter discourse of how living in a favela is more than the negative perceptions that are the dominant perceptions in society. When discussing the marginalization and violence, seven of the participants expressed to me that the situation is improving (i.e., Betinho, Felipe, Junior, Nicolas, Rani, Renato, Rodrigo). This point of view is aligned with what Perlman (2010) found. Favelas are marginalized, but they are not places of inescapable poverty and a hopeless situation. Over the decades there have been government policies and practices to invest in and normalize the favelas. This affect of development in Pereira da Silva is evident in the positive characteristics that were mentioned about where the participants live.

When talking about what it was like for them to live in Pereira da Silva, there were more positive characteristics expressed than negative associations. Eight participants discussed the calm environment that exists in Pereira da Silva (i.e., Betinho, Gão, Junior, Luciano, Nicolas, Rafael, Rodrigo, Teibe). The calm environment that exists today in Pereira da Silva is in part due to the success of the government's favelabairro model of integration in the 1990s. Calmness is also part of what makes Rio's 
favelas an increasingly popular tourist destination (Freire-Medeiros, 2009; Perlman, 2010).

Seven participants discussed the community feeling that was a result of having many friends and family that also lived in Pereira da Silva (i.e., Betinho, Junior, Luciano, Maiquinho, Nicolas, Paulo Vitor, Pedro). In terms of subjective claim analysis, the value placed on friends and family in Pereira da Silva is something that has helped these participants develop confidence, a sense of support, and a positive personal identity. In his discussion of a struggle for humanization, Freire (2009) wrote about the love that must be in the oppressed for the oppressed in order to advance toward liberation and class mobility. The support that these participants feel in Pereira da Silva is part of the humanization process.

Four participants viewed the central location as a positive aspect of where they live (i.e., Gão, Rafael, Renato, Rodrigo). In a subjective claim analysis, the central location in the South Zone makes many daily activities, such as work and transportation, much easier and much more enjoyable. Perlman (2010) also found that these factors in part contributed to social mobility across generations. The calm environment, network of family and friends, and central location make Pereira da Silva a valuable place to live. This description shows that favelas are not places of only violence and poverty, but they can be places where people enjoy living. According to Freire (2009), the value that the participants of this study place on where they live position them as well-prepared to work toward the liberation of favela residents, and their equal participation in society. 


\section{Countering Through Art the Dominant Characterization of Favelas}

In order for there to be progress made toward the liberation of oppressed classes, Freire (2009) emphasized the importance of dialogue throughout the process. Morrinho's artwork is a way that the participants dialogue about their place in society, their perception of their daily reality, and what changes they hope to come in the future. Morrinho does not completely reject the notion that there exist heightened levels of violence in Rio's favelas. This lived reality of violence was mentioned in the interviews, the film, and in the description of the artwork by nearly all of this study's participants as one of the principle scenes at Morrinho (i.e., Cilan, Criistian, Gão, Junior, Luciano, Maiquinho, Nicolas, Paulo Vitor, Pedro, Rani, Rafael, Renato, Rodrigo). Violence is something that Rio's favelas are known for in the general population. In their artwork, the Morrinho participants do not deny that this is true. They hold the violence in the favelas as a central theme to the reality that they portray, and include it as part of their dialogue about their place in society (Freire, 2009).

Violence in favelas is a part of the dialogue that takes place in Morrinho's artwork, but fourteen of the seventeen participants emphasized in the interviews, the film, and the description of the artwork that much more was portrayed at Morrinho than violence (i.e., Betinho, Budé, Cilan, Felipe, Gão, Junior, Luciano, Nicolas, Paulo Vitor, Pedro, Rafael, Rani, Renato, Rodrigo). This point of view is similar to the many social groups that Oosterbaan (2009) wrote about. Morrinho does not deny the security risks that can exist in a favela, but they are more complex than this single-dimensional view.

Further discussing the personal reality of someone who lives in a favela, nine of the participants expressed in the interviews and film how scenes acted out at Morrinho 
show daily activities of what a person anywhere may be performing, such as a mother bringing her children to school, or parents working to provide for their families (i.e., Cilan, Criistian, Junior, Maiquinho, Paulo Vitor, Pedro, Rafael, Rodrigo, Teibe). This vision of favela life is seen in the play that takes place at the model, and the documentary film.

Seven of the participants talked in their interviews and the description of the artwork of how they believe that Morrinho represents an alternative version of the dominant negativity that is broadcast in society about the favelas (i.e., Betinho, Cilan, Junior, Rafael, Renato, Rani, Teibe). According to a normative-evaluative analysis, Morrinho's artwork communicates an alternative version of the negative images most commonly portrayed of favelas and allows for people to see a more balanced vision of what life in a favela is like.

Three of the participants said in the film and description of the artwork that they believe Morrinho shows a positive example of what can exist in a favela (i.e., Betinho, Cilan, Rani). None of the participants agreed with the entirely negative image of favelas, and Betinho spoke with me in agreement with the more positive message that Morrinho communicates being the more honest message about Rio's favelas. Cilan and Rani spoke to me about the with the more honest and complete message that Morrinho communicates.

Four participants addressed how Morrinho is an advocate for more social acceptance (i.e., Cilan, Luciano, Maiquinho, Teibe). Luciano's words are possibly the most illustrative of this belief. Speaking of Photo 166, he spoke of peace and equality as the main objectives of favela residents. He also described discrimination that the 
participants have faced and the marginalization that favelas face by government forces as what the Morrinho artwork contests. Those who live in favelas deserved to be included in the grouping of personhood and gente (DaMatta, 1991; Perlman, 2010). Morrinho's dialogue communicates an important message of inclusion and acceptance (Freire, 2009).

\section{Internal Character Development Associated with Morrinho}

The participation in the process of portraying their own version of life in a favela has been a largely positive experience for the participants. Thirteen of the seventeen participants talked in their interviews, the film, and the description of the artwork about how the game that is played at Morrinho served as an escape from the social ills that exist in Pereira de Silva (i.e., Betinho, Budé, Cilan, Criistian, Felipe, Gão, Junior, Renato, Paulo Victor, Pedro, Rafael, Rodrigo, Teibe). Junior described the high value that he place on Morrinho as a game when he was younger. In terms of subjective truth claims, Junior's words highlight the importance of social projects in the role of youth development. Morrinho's emphasis on the participants' own reality and the role that the participants had in creating the project was partial in leading to its popularity. As a result, Morrinho served as a popular activity for positive and safe character development.

Twelve of the participants expressed gratitude for the opportunities of work and travel that Morrinho afforded them (i.e., Budé, Cilan, Criistian, Felipe, Luciano, Nicolas, Paulo Victor, Rafael, Rani, Renato, Rodrigo). Morrinho has provided its participants with opportunities that would not otherwise be available to them. Morrinho has served as an educational experience that Freire (2003) addressed as important in the struggle for liberation. This experience is a demonstration that if given support and guidance, 
someone from limited resources can achieve the same objectives as someone with more socioeconomic resources.

Eight of the participants talked in the interviews, the film, and the description of the artwork of the recognition that they received as artists resulting from their involvement with Morrinho (i.e., Cilan, Felipe, Junior, Luciano, Maiquinho, Rafael, Rani, Renato). In terms of subjective truth claims, the recognition for creativity and for using their imagination is something that these participants have pride in and is something that has built their self-esteem. The use of art as youth development is something that Gohn (2007) found was common in NFE in Brazil.

Four participants told me in their interviews, the film, and the discussion of the artwork of how their experience with Morrinho increased their self-esteem (i.e., Cilan, Felipe, Junior, Pedro). Aligned with the goals of NFE (Gohn, 1999; Hoppers, 2006; Simson, Park, \& Fernandes, 2001a), Morrinho allow the participants to believe in their abilities. Felipe was perhaps the most demonstrative in his increase in self-esteem when he said that his experiences with Morrinho made him feel more like gente. Analyzed for subjective truth claims, Morrinho has allowed Felipe to believe that he is a productive members of society, whereas before he did not. Increasing the participants' self-esteem is also key to healthy forms of recognition and affection as Luiz Eduardo Soares, researcher at the Institute for the Study of Religion (ISER) and former National Secretary for Public Security, emphasized to both Neate and Platt (2010) and Perlman (2010). This aspect of Morrinho is a further demonstration of the organization work in critical pedagogy to liberate the participants through dialogue about their own lived situation (Freire, 2009). 
For six participants, their experiences with Morrinho allowed them to broaden their cultural understanding so that they would be able to culturally fit in with middle class Brazilian, and more easily be able to relate to people from other countries (i.e., Junior, Luciano, Rafael, Rani, Rodrigo, Paulo Vitor). This finding is aligned with what Perlman (2010) researched, that living in a favela and not looking like a young person from the South Zone of Rio de Janeiro was an impediment to finding a job. The ability to fit in as someone from the asfalto is one of the methods that participants had told me about earlier that allows them to avoid discrimination based on perception of their appearance or manner of speech. This agrees with the possibility through social mobility described by the theory of habitus (Bourdieu, 1977). Analyzed for subjective truth claims, the participants communicated that they valued the code switching that they learned from their experiences with Morrinho. They believed this to be a valuable tool for avoiding discrimination and for achieving respect and employment in the asfalto. This educational aspect of Morrinho is central to the concept of critical pedagogy, whereby the participants' personal agency is enacted to move them past their traditional demonstrations of taste that signify them as belonging to an oppressed class (Bourdieu, 1977; Freire, 2003; Leistyna \& Woodrum, 1996).

Central to Morrinho's educational component is the role-modeling that was provided to the participants that gave them the guidance with which to confront the problems that they may be facing (Freire, 2009). Five of the participants talked about in the interviews and the film the positive role modeling that they were exposed to as a result of their association with Morrinho (i.e., Budé, Cilan, Criistian, Junior, Nicolas). This role-modeling served the purpose of steering the participants away from illegal 
influences such as drug trafficking and crime affiliation. Morrinho has provided a space in which the participants can safely discuss with their peers the issues that they are experiencing and having a difficult time dealing with. In my experience with Morrinho, I saw many examples of the peer support. Members of the group encouraged each other to take part in activities that would lead to positive personal development. I have also noticed that Morrinho provided a safe alternative space to be in when one of the participants did not want to be at home. Aligned with NFE goals, the role-modeling and mentoring that the participants provide for each other contributes to the positive character development that takes place at the Morrinho organization (Gohn, 1999; Hoppers, 2006; Simson, Park, \& Fernandes, 2001a).

Fifteen of the participants talked in their interviews, the film, and their description of the artwork about the activities of Morrinho to spread this positive influence to other youth of Pereira da Silva (i.e., Betinho, Budé, Cilan, Criistian, Felipe, Maiquinho, Junior, Luciano, Nicolas, Paulo Vitor, Pedro, Rafael, Rani, Renato, Rodrigo). Maiquinho mentioned the idleness of young adolescents that Leeds (2007), Neate and Platt (2010), and Perlman (2010) wrote about as problematic for favela youth, because it could lead them to becoming involved in the local organized crime. For a population the age that many public school youth drop out of school and are too young to legally work, belonging to an organization which creates a positive self-identity makes it less likely that these youth will join another type of organization that will ultimately create personal security problems for them. 


\section{Limitations}

This study has focused on one NFE program based in a favela in the South Zone of Rio de Janeiro. A study that expanded to other organizations that work with a similar population may have yielded other results. Further shaping this study is that the population of the Morrinho organization is all male. Had this research analyzed the female point of view of life in a favela, the conclusions may have been different.

\section{Recommendations for Practice and Policy}

The findings of the study have implications for policy and practice in working with the youth of an oppressed population. This research shows the value of youth development programs to promote understanding among different socioeconomic classes. Freire (2009) considered this a critical step in liberation of the oppressed and the participation of all peoples in society. The experiences that the participants of this study had as a part of Morrinho allowed them to dialogue about their position in society, and the artistic demonstration of the perception allowed them to work and travel with people from middle and upper classes in Brazil and abroad. Through this process, the participants were able to develop code switching skills that allowed them to not be immediately identified as a favela resident. This in turn allowed the participants to avoid discrimination, and to mobilize their own personal agency. The participants were able to choose which personal identity they wanted to demonstrate, according to the situation they were in.

Further application of this research is for educators to incorporate application of the students lived reality in the curriculum. According to Freire (2009), if an educational curriculum is to work toward equality, it "must be forged with, and not for, the 
oppressed" (p. 48). Incorporation of a student's lived experiences allows the student to build upon previous knowledge and deepen his or her understanding of what is being studied. This aspect of Morrinho encouraged the participants to engage in the organization's activities. As a result the participants experienced increased self-esteem, opportunities for work and travel, critical gained recognition as artists, broadened their cultural understanding, gained access to a positive role-modeling experience, and were part of a social project that fomented development through group membership.

This study has shown the positive effects of incorporation of the arts in curriculum development. The recognition as artists is a source of pride for the participants of this study, and allowed them to realize their potential. This recognition showed them their value as persons, and allowed them to work, travel, and meet people that would not typically be possible for a favela resident. This research has demonstrated the transformative power of art in being used as a dialogical tool that can growth in personal identity. With this defined identity, one can more ably face hardships.

Promoting understanding among various classes, using a student's reality in curriculum development, and incorporating arts in the curriculum work toward an ultimate goal of empowering youth for positive development. As is the goal of NFE, an end objective of youth empowerment can have important consequences for those who do not come from the dominant classes of society. In the Brazilian tradition of NFE, this empowerment leads to what Freire (2009) termed conscientização, or the development of a critical consciousness. This critical consciousness allows students to work toward their own equal treatment by becoming political actors, which is necessary to work toward 
equal treatment in policy and practice toward favelas of the Rio de Janeiro government and society.

\section{Recommendations for Research}

Findings of this study suggest several areas of future research. The discussion of the different terms used to refer to a favela is a representation of the importance of word choice; however, I did not see any research on this topic. The participants expressed either a preference or a rejection of the use of the words favela, morro, and comunidade based on the social, historic, and political weight each term carries. There is generally recognition that due to the level of development in the favelas, and the government investment, they are considered communities, or comunidades. However, a discourse analysis on the nuances of the three words, and others, could lead to interesting conclusions on the word choice in Portuguese to refer to these areas.

Of further interest for future research, the literature was highly critical of Brazil's school system for having high dropout and grade repetition rates (Cardoso \& Verner, 2007; Ireland, 2007); and for making a college education unattainable for most children who attend public school (Reiter, 2009). Research about teachers in public schools in Brazil and school quality found high student to teacher ratios, high rates of absenteeism among teacher, and high rates of teacher burnout (Gatti \& Barretto, 2009). Four participants talked to me about their personal difficulties in graduating from the school system (i.e., Felipe, Luciano, Maiquinho, Rani), and seven participants talked of negative experiences with the school system (i.e., Betinho, Budé, Felipe, Junior, Rani, Rodrigo, Teibe). However, some of these same participants talked of the positive experiences that they had in school (i.e., Betinho, Gão, Nicolas, Paulo Vitor, Pedro, Renato, Teibe). 
Brazil's public schools have areas in which they need to improve. Though, this finding suggests that those who took part in the school system may not have much else to compare the experience to since they have not had educational experiences outside of the public school system. Further research into the perceptions of quality education by the students of that system may elucidate these findings of this study.

This study was conducted with a partial goal of adding to the body of literature of NFE in Brazil, and specifically in Rio de Janeiro. With the large number of NFE programs registered with the Rio de Janeiro CMDCA that work with youth and adolescents, it is important to continue the research of NFE programs in Rio de Janeiro and Brazil. With a public school system that is highly criticized, and a large number of programs supplementing this education, further research could be useful in understanding the best practices for working with the youth from all sectors of society.

\section{Summary}

This chapter concluded the study with a detailed response to the research question, limitation to the study, recommendations for practice and policy, and recommendations for future research. The purpose of this visual critical ethnography was to examine the Morrinho participants' experiences of living in a Rio de Janeiro favela as communicated through their film, artwork, and words. This study discussed the challenges of living in a favela, as well as the advantages. The participants told me of violence faced as a result of the organized crime and police brutality, and they faced oppression as a result of government practices and societal discrimination. However there were ways that participants told me that they were able to avoid interpersonal discrimination, and they told me of many positive aspects of living in Pereira da Silva. 
Participation in Morrinho was analyzed to allow the participants to dialogue about their position in society. The artwork that the participants produce as a part of Morrinho largely counters the dominant perception of Rio's favelas. While there does exist trafficking and organized crime, they are also communities where families live their daily lives, work to support their children, and celebrate holidays and special occasions. Morrinho's principal message is one of inclusion for favela residents and for equal treatment of favelas by society and all of its actors. 


\section{REFERENCES}

Abramovay, M., \& M. Rua, D. G. (2002). Violências nas escolas. [Violence in the schools]. Brasília: UNESCO.

Anderson, J. L. (2009, October 20). Through Rio's favelas, guns drawn. The New Yorker. Retrieved from http://www.newyorker.com/online/blogs/newsdesk/2009/10 police-raid-riofavela.html

Arias, E. D. (2004). Faith in our neighbors: Networks and social order in three Brazilian favelas. Latin American Politics and Society, 46(1), 1-38.

Arias, E. D., \& Rodrigues, C. D. (2006). The myth of personal security: Criminal gangs, dispute resolution and identity in Rio de Janeiro's favelas. Latin American politics and society, 48(4), 53-81.

Bourdieu, P. (1977). Outline of a theory of practice. (R. Nice, Trans.) Cambridge, U.K.: Cambridge University Press.

Bourdieu, P. (2003). The social definition of photography. In J. Evans \& S. Hall (Eds.), Visual culture: The reader (pp. 162-180). Thousand Oaks, CA: Sage.

Cardoso, A. R., \& Verner, D. (2007). School drop-out and push-out factors in Brazil: The role of early parenthood, child labor, and poverty. (Research Working Paper No. 4178). Retrieved from World Bank website: http://wwwwds.worldbank.org/external/default/WDSContentServer/IW3P/IB/2007/03/21/00 0016406_20070321094137/Rendered/PDF/wps4178.pdf

Carspecken, P. F. (1996). Critical ethnography in educational research: A theoretical and practical guide. New York, NY: Routledge.

Da Matta, R. (1991). Carnivals, rogues, and heroes: An interpretation of the Brazilian dilemma (J. Drury, Trans.). Notre Dame, IN: University of Notre Dame Press.

Denzin, N. K. (1970). The research act: A theoretical introduction to sociological methods. Chicago, IL: Aldine.

Entidades cadastradas [Registered Entities]. (n.d.). Conselho municipal dos direitos da criança e do adolescente [Municipal council for the rights of children and adolescents]. Retrieved from http://www.cmdcario.rj.gov.br/entidades_cadastradas.html 
Farrell, J. P. (2008). Community education in developing countries: The quiet revolution in schooling. In F. M. Connelly, M. F. He, \& J. Phillion (Eds.), The Sage Handbook of Curriculum and Instruction (pp. 369-389). Thousand Oaks, CA: Sage Publications.

Fernandes, S. (2011). Close to the edge: In search of the global hip hop generation. Brooklyn, N.Y.: Verso.

Freire, P. (2009). Pedagogy of the oppressed. (M. B. Ramos, Trans.). New York: Continuum International Publishing Group.

Freire-Medeiros, B. (2009). The favela and its touristic transits. Geoforum, 40, 580-588. doi: 10.1016/j.geoforum.2008.10.007

Freire-Medeiros, B. (2005). A favela que se vê e que se vende: Reflexões e polêmicas em torn de um destino turístico [The favela that is seen and sells itself: Reflexions and polemics of a tourist destination]. Revista brasileira de ciências sociais (22)65, pp. 61-72.

Gates, H. L. (2011) Black in Latin America. New York: New York University Press.

Gatti, B. A. \& Barretto, E. S. S. (2009). Professores do Brasil: Impasses e desafios [Teachers of Brazil: Obstacles and challenges]. Brasília, Brazil: UNESCO. Retrieved from http://unesdoc.unesco.org/images/0018/001846/184682por.pdf

Gavião Vector Docs \& TV Morrinho. (Producer), \& Gavião, F. \& Oliveira, M. (Directors). (2007). Deus sabe tudo mas não é X-9 [God Knows Everything But He's Not A Snitch] [Motion Picture]. Brazil: Abbas Filmes.

Gohn, M. G. (1999). Educação não formal e cultural política: Impactos sobre o associativismo do terceiro setor. [Non-formal education and cultural politics: Impacts on the association of the informal sector]. São Paulo, Brazil: Cortez.

Gohn, M. G. (2007). Não-fronteiras: Universos da educação não-formal [Non-borders: Universes of non-formal education]. São Paulo, Brazil: Catalogação Itaú Cultural.

Goldstein, D. M. (2003). Laughter out of place: Race, class, violence, and sexuality in a Rio shantytown. [Kindle Edition]

Grupo Cultural AfroReggae. (2010). Missão e visão [Mission and vision]. Retrieved from http://www.afroreggae.org/wp/institucional/missao/

Guimarães, E. (1998). Escolas, galeras e narcotráfico. Rio de Janeiro, Brazil: Editora UFRJ. 
Hafemeister, B. E. (2011). An analysis of a small favela-based youth organization. In M.S. Plakhotnik, S. M. Nielsen, \& D. M. Pane (Eds.), Proceedings of the Tenth Annual College of Education \& GSN Research Conference (pp. 48-55). Miami: Florida International University. http://coeweb.fiu.edu/research_conference.

Hall, S. (1997). Introduction. In S. Hall (Ed.), Representation: Cultural representations and signifying practices (pp. 1-11). London, United Kingdom: Sage.

Hoppers, W. (2006). Non-formal education and basic education reform: A conceptual review. Retrieved from UNESCO website: http://unesdoc.unesco.org/images/0014/001444/144423e.pdf

Human Rights Watch. (2009). Lethal Force: Police Violence and Public Security in Rio de Janeiro and São Paulo. Retrieved from http://www.hrw.org/sites/default/files/reports/brazil1209webwcover.pdf

Ireland, T. D. (2007). Brazil Non-Formal Education: Country Profile Prepared for the Education for All Global Monitoring Report 2008. (UNESCO Report No. 2008/ED/EFA/MRT/PI/45. Retrieved from http://www.unesco.org/en/education/publications/

Itaú Cultural. (n.d.). Rumos. Retrieved from the Itaú Cultural website: http://itaucultural.org.br/index.cfm?cd_pagina $=2691$

Jaguaribe, B. (2009). Hijacked by realism. Public culture (21)2, 219-227.

Kincheloe, J. L. \& McLaren, P. L. (1994). Rethinking critical theory and qualitative research. In N. K. Denzin \& Y. S. Lincoln (Eds.) Handbook of qualitative research (pp. 138-157). Thousand Oaks, CA: Sage.

Leeds, E. (2007). Rio de Janeiro. In K. Koonings, \& D. Kruijt (Eds.), Fractured cities: Social exclusion, urban violence \& contested spaces in Latin America (pp. 23-35). New York, NY: Zed Books.

Leistyna, P. \& Woodrum, A. (1996). Context and culture: What is critical pedagogy. In P. Leistyna, A. Woodrum, \& S. A. Sherblom (Eds.), Breaking Free: The Transformative Power of Critical Pedagogy. (pp. 1-7). Cambridge, MA: Harvard Educational Review.

Lemle, M. (2011, January 4). Mais pobreza, mais jovens assassinados [More poverty, more youth killed]. Comunidade Segura.

Lincoln, Y. S. \& Guba, E. (1985), Naturalistic inquiry, Beverly Hills, CA: Sage. 
Merriam, S. B. (2002). Introduction to qualitative research. In S. B. Merriam (Ed), Qualitative research in practice: Examples of discussion and analysis (pp. 3-17). New York: John Wiley \& Sons

Ribeiro, B. A., et al. (Producers), \& Meirelles, F. and Lund, K. (Directors). (2002) Cidade de Deus. [City of God] [Motion Picture]. Brazil: Buena Vista International.

Neate, P. \& Platt, D. (2010). Culture is our weapon: Making music and changing lives in Rio de Janeiro. New York, N.Y.: Penguin Books. [Kindle Edition]

Oosterbaan, M. (2009). Sonic supremacy. Sound, space and Charisma in a favela in Rio de Janeiro. Critique of Anthropology. 29(1), 81-104

Pardue, D. (2008). Ideologies of marginality in Brazilian hip hop. New York, NY: Palgrave Macmillan.

Patton, M. Q. (2002). Qualitative evaluation and research methods (3rd ed.). Newbury Park, CA: Sage.

Perlman, J. (2006). The metamorphosis of marginality: Four generations in the favelas of Rio de Janeiro. The ANNALS of the American Academy of Political and Social Science, 606, 154-177. doi: 10.1177/0002716206288826

Perlman, J. (2010). Favela: Four decades of living on the edge in Rio de Janeiro. New York, N.Y.: Oxford. [Kindle Edition]

Pink, S. (2007). Doing visual ethnography: Images, media, and representation in research. Thousand Oaks, CA: Sage.

Reiter, B. (2009). Negotiating Democracy in Brazil: The Politics of Exclusion. Boulder, CO: First Forum Press.

Ribeiro, D. (1995). O povo Brasileiro: A formação e o sentido do Brasil [The Brazilian people: The formation and meaning of Brazil] (2nd ed.). Companhia da Letras: São Paulo, Brazil.

Rocha, L. M. (2009). Uma favela "diferente das outras?". [A favela "different from the others?"']. (Doctoral Dissertation). Instituto Universitário de Pesquisas do Rio de Janeiro, Rio de Janeiro, Brazil.

Rose, G. (2001). Visual methodologies. Thousand Oaks, CA: Sage. 
Roth-Gordon, J. (2009). Language that came down the hill: Slang, crime and citizenship in Rio de Janeiro. American Anthropologist, 111(1), 57-68. doi: 10.1111/j.15481433.2009.01077.x

Scherer, J. C. (1995). Ethnographic photography in anthropological research. In S. Hockings (Ed.), Principles of visual anthropology (pp. 201-216). New York, N.Y.: Mouton de Gruyter.

Simson, O. R. M., Park, M. B., \& Fernandes, R. S. (Eds.). (2001a). Educação não formal-cenários da criação [Non-formal education - scenes of creation]. São Paulo, Brazil: Editora Unicamp.

Simson, O. R. M., Park, M. B., \& Fernandes, R. S. Introdução [Introduction]. (2001b). In O. R. M. Simson, M. B. Park, \& R. S. Fernandes (Eds.), Educação não formalcenários da criação [Non-formal education - scenes of creation]. (pp. 9-19). São Paulo, Brazil: Editora Unicamp.

Sneed, P. (2008). Favela utopias: The bailes funk in Rio's crisis of social exclusion and violence. Latin American research review, 43(2), pp. 57-79.

Swartz, D. (1997). Culture and power: The sociology of Pierre Bourdieu. The University of Chicago Press: Chicago, IL.

Telles, E. (2004). Race in another America: The significance of skin color in Brazil. Princeton University Press: Princeton, N.J.

Treut, M. (Producer). (2001). Warrior of light [Motion picture]. Brazil: Hyena Films.

Waiselfisz, J. J. (2013) Mapa da violência 2013: Homicídios e juventude no Brasil. [Map of violence 2013: Homicides and youth in Brazil]. Centro Brasileiro de Estudos Latino-Americanos: Rio de Janeiro FLASCO Brasil. Retrieved from http://www.mapadaviolencia.org.br/pdf2013/mapa2013_homicidios_juventude.pd f How to cite?

Weakland, J. H. (1995). Feature films as cultural documents. In S. Hockings (Ed.), Principles of visual anthropology (pp. 45-67).

Wengraf, T. (2001). Qualitative research interviewing: Biographic narrative and semistructures methods. Thousand Oaks, CA: Sage.

Williams, R. (1994). The analysis of culture. In J. Storey (Ed.), Cultural theory and popular culture (pp. 56-64). New York, N.Y.: Pearson Prentice Hall. 
Yúdice, G. (2003). The expediency of culture: Uses of culture in the global era. Durham, N.C.: Duke University Press.

Zaluar, A. (1994). Cidadões não vão ao paraíso: Juventude e política social [Citizens don't go to paradise: Youth and social politics]. São Paulo, Brazil: Editora da Unicamp. 


\title{
APPENDIX A
}

\author{
Interview Guide in English
}

\section{Profile Questions}

1. Do you want to use your name or do you prefer to use another name to protect your identity?

2. How old are you?

3. What race would you say that you are?

4. How old were you when you started with Morrinho?

5. How long have been a part of Morrinho?

6. How many years have you lived in Pereira da Silva?

Questions About What a Favela Is And What It's Like To Live In A Favela

7. Is talking to someone who does not know Rio de Janeiro well, you would say that you live in what part of the city?

a. How would you describe where you live?

b. What are the benefits and the disadvantages of living here?

8. Would you say that Pereira da Silva is a morro, a comunidade, or a favela?

a. What are the differences and the similarities of these terms?

9. Do you think that there is discrimination against the favelas? Can you explain?

10. What is the highest level of education that you finished?

a. How would you describe your experiences in school?

Question About Experiences With Morrinho And Morrinho's Art

11. Speaking of Morrinho, why the name "Morrinho"?

12. What activities take place at Morrinho? How would you describe it?

a. What kind of scenes are portrayed at Morrinho, in the films and the exhibitions?

b. What type of experiences have you had with Morrinho?

13. What does Morrinho communicate about the favelas of Rio de Janeiro?

a. Would you say that Morrinho communicates something specific of Pereira da Silva in contrast with the other favelas of Rio de Janeiro?

b. Would you say that Morrinho shows the day-to-day of people who live in a favela? What is it?

14. Have girls participated at Morrinho?

15. Would you say that your participation at Morrinho has changed your perception of society, of Pereira da Silva, Rio de Janeiro, Brazil, or other countries?

a. On it's website, Morrinho is described as a social and cultural project. Do you agree with this description?

b. Do you believe that Morrinho created job opportunities for you?

16. Speaking of the documentary, what does the title mean "God Knows Everything But He's Not A Snitch"?

17. What is a $\mathrm{X}-9$ ? 
18. What is the documentary about?

a. Do you agree with how Morrinho is portrayed in the film?

b. Are there parts of the documentary that you like more than others? Are there parts that you don't like?

c. Early in the film, the song "The favela is a social problem" is played, what does this mean for you? Do you agree with what this song says?

d. In the documentary several people speak of educational and therapeutic aspects of Morrinho. Do you agree that participating with Morrinho has been educational or therapeutic for you?

19. What would you say that Morrinho communicated to others who see the model?

a. Journalists have said that Morrinho reminds them of a song, a film, or a book. Would you say that Morrinho reminds you of a song, a film, or a book?

b. If you think of what the model looks like it today, would you say there is a part of Morrinho that is more communicative, that represents better what Morrinho is for you?

20. I took 206 photos of the model with the intention of not changing the colors, the light, and the focus. I did not want to change what the eye sees in real life. Could you tell me which photos you like, and which photos best represent Morrinho, and why?

21. Do you have other photos that you would like to share with me that you think are representative of Morrinho? 
Interview Guide In Portuguese

Perguntas de Perfil

1. Você quer usar seu nome ou prefere usar outro nome para proteger sua identidade?

2. Quantos anos tem?

3. Qual raça diria que você é?

4. Quantos anos tinha quando começou com o Morrinho?

5. Faz parte do Morrinho há quanto tempo?

6. Quantos anos você mora na Pereira da Silva?

Perguntas de o quê e uma favela e como é viver em uma favela

7. Se falar com alguém que não conheça o Rio de Janeiro muito bem, você diria que mora em que parte da cidade?

a. Como descreveria onde mora?

b. O que seria o bom e o ruim de morar aqui?

8. Classificaria Pereira da Silva como morro, comunidade, ou favela?

a. Quais são as diferenças e as semelhanças desses termos?

9. Você acha que tem discriminação contra as comunidades? Pode explicar?

10. Você completou a escola até qual grau?

a. Como descreveria suas experiências nas escola?

Perguntas das experiências com Morrinho e a Arte de Morrinho

11. Falando do Morrinho, por quê se colocou o nome Morrinho?

12. O quê é Morrinho? Como descreve?

a. Quais atividades acontecem no Morrinho?

b. Poderia me descrever quais cenas estão retratadas no Morrinho na brincadeira, nos filmes, e nas exposições?

c. Quais experiências teve no Morrinho?

13. O quê diria que Morrinho comunica dos morros do Rio de Janeiro?

a. Diria que Morrinho comunica algo específico da Pereira da Silva em contraste com as outras comunidades do Rio de Janeiro?

b. Diria que Morrinho mostra o dia-a-dia de pessoas que moram na comunidade? O quê é?

14. Tiveram meninas que participaram no Morrinho?

15. Você diria que sua participação no Morrinho mudou como você percebe a sociedade de Pereira da silva, Rio da Janeiro, Brasil o outros países?

a. No site de Morrinho se descreve como um projeto social e cultural. Você está de acordo com essa descrição?

b. Acha que Morrinho criou oportunidades profissionais para você?

16. Falando do documentário, o quê quer dizer o título do documentário: "Deus sabe tudo, mas não é X-9?"

17. O quê é um $X-9$ ? 
18. De quê fala o documentário?

a. Você está de acordo com como está retratado o Morrinho no documentário?

b. Tem partes do documentário que você gosta mais do que outras? Tem parte que não gosta?

c. No início do filme toca a música "A favela é um problema social”, o quê quer dizer isso para você? Está de acordo com essa música, o que diz?

d. No documentário várias pessoas falam de aspectos educacionais e terapêuticos do Morrinho. Você está de acordo que participar no Morrinho tem sido educacional e/ ou terapêutico para você?

19. O quê diria que Morrinho comunica a pessoas que veem a maquete?

a. Tem jornalista que vieram aqui e eles falaram que Morrinho lembra a eles de algum libro, algum filme, alguma música. Você diria que tem alguma música, livro ou filme que te lembra de Morrinho?

b. Se você pensa da maquete como é hoje em dia, acha que tem uma parte que é mais comunicativa, que representa melhor o que é Morrinho para você?

20. Eu tirei 206 fotos da maquete com a intenção de não mudar as cores e não mudar a luz e o foco. Minha intenção foi não mudar muito como o olho vê na vida real. Vou te perguntar se você poderia me dizer quais fotos gosta, quais mais acha que representam o Morrinho melhor e por quê.

21. Você tem outras fotos que gostaria compartilhar comigo que acha que são representativas de Morrinho? 


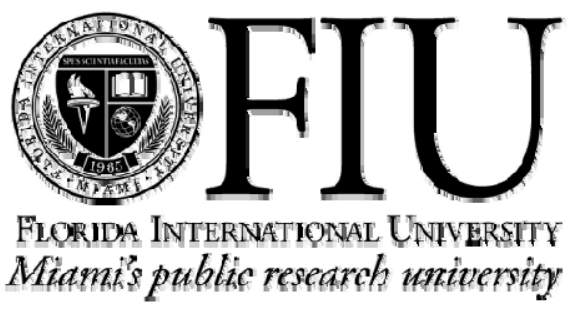

\section{ADULT CONSENT TO PARTICIPATE IN A RESEARCH STUDY \\ A Critical Ethnography of Youth Development in a Brazilian Favela}

\section{PURPOSE OF THE STUDY}

You are being asked to be in a research study. The purpose of this study is to describe what the Morrinho youth communicate about their experiences of living in a favela through their film, artwork, and words.

\section{NUMBER OF STUDY PARTICIPANTS}

If you decide to be in this study, you will be one of approximately 14 people in this research study.

\section{DURATION OF THE STUDY}

Your participation will require between 1 and 2 hours.

\section{PROCEDURES}

If you agree to be in the study, we will ask you to do the following things:

1. Hold a conversation and answer some questions about Morrinho and what you mean for your artwork to communicate about your daily life.

2. Questions may concern interpreting sections of the documentary film or photos of the Morrinho project.

3. All interviews will be audio and video recorded.

\section{RISKS AND/OR DISCOMFORTS}

The only possible risk of this study is that you may be identified due to the public nature of the Morrinho project. The researcher intends on using images of the Morrinho artwork and the film of the interviews for academic purposes only, but this makes it possible for somebody to identify whom you are and that you have participated in this study.

\section{BENEFITS}

The main desired benefit is for readers of this research to understand the day to day reality of a male youth who lives in a favela in Rio de Janeiro. 


\section{ALTERNATIVES}

There are no known alternatives available to you other than not taking part in this study.

\section{CONFIDENTIALITY}

The records of this study will be kept private and will be protected to the fullest extent provided by law. Raw data will be stored securely and only the researcher team will have access to the records. Your records may be reviewed for audit purposes authorized by the university or other agents who will be bound by the same provisions of confidentiality. It may be possible for someone to find out that you participated in this study.

\section{COMPENSATION AND COSTS}

You will not receive a payment for your participation. You will not be responsible for any costs to participate in this study.

\section{RIGHT TO DECLINE OR WITHDRAW}

Your participation in this study is voluntary. You are free to participate in the study or withdraw your consent at any time during the study. Your withdrawal or lack of participation will not affect any benefits to which you are otherwise entitled. The investigator reserves the right to remove you without your consent at such time that they feel it is in the best interest.

\section{RESEARCHER CONTACT INFORMATION}

If you have any questions about the purpose, procedures, or any other issues relating to this research study, you may contact Bryn Hafemeister at FIU, +1.972.415.9661, be.hafemeister@gmail.com.

\section{IRB CONTACT INFORMATION}

If you would like to talk with someone about your rights of being a subject in this research study or about ethical issues with this research study, you may contact the FIU Office of Research Integrity by phone at +1.305-348-2494 or by email at ori@fiu.edu.

\section{PARTICIPANT AGREEMENT}

I have read the information in this consent form and agree to participate in this study. I have had a chance to ask any questions I have about this study, and they have been answered for me. I understand that I am entitled to a copy of this form after it has been read and signed.

Signature of Participant

Printed Name of Participant

Signature of Person Obtaining Consent
Date

\section{Date}




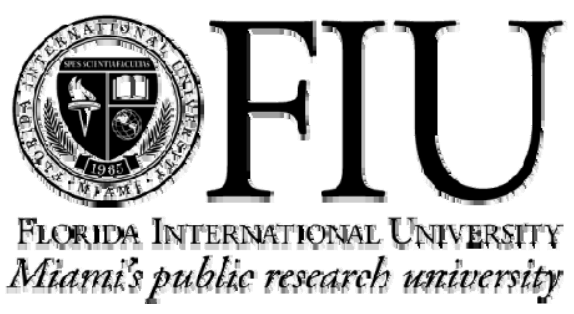

\section{CONSENTIMENTO DE ADULTO PARA PARTICIPAR NUMA PESQUISA}

Uma etnografia crítica de desenvolvimento de jovens numa favela brasileira

\section{PROPOSTA DA PESQUISA}

Estamos pedindo para você participar nesta pesquisa. A proposta da pesquisa é descrever o que os jovens de Morrinho comunicam da suas experiências de viver numa favela através do filme documentário, a maquete de Morrinho, e as palavras dos jovens.

\section{NUMERO DE PARTICIPANTES DA PESQUISA}

Se decidir participar nesta pesquisa, você será um de aproximadamente 14 pessoas na pesquisa.

\section{DURAÇAO DA PESQUISA}

Sua participação exigirá entre uma e duas horas de seu tempo.

\section{PROCEDIMENTOS}

Se você concordar participar nesta pesquisa, pediremos você fazer o seguinte:

1. Responder algumas perguntas e conversar sobre Morrinho e o que a maquete e a brincadeira querem comunicar de sua vida diária.

2. A perguntas podem haver com sua interpretação de secções do filme documentário ou fotos da maquete de Morrinho.

3. Todas as entrevistas serão gravados com áudio e vídeo.

\section{RISCO E/OU DESCONFORTOS}

O único risco possível desta pesquisa é que devido `a publicidade que recebe Morrinho, alguém poderá identificar você como participante desta pesquisa. A pesquisadora tem a intenção de usar os imagens da maquete de Morrinho e filme das entrevista para propósitos acadêmicos, e isto faz possível para alguém te identificar como participante desta pesquisa.

\section{BENEFICIOS}

O principal beneficio desejado para os leitores desta pesquisa é compreender a realidade diária de um jovem que vive numa favela no Rio de Janeiro.

\section{ALTERNATIVOS}

Não tem opções alternativas, mas você não precisa participar na pesquisa. 


\section{CONFIDENCIALIDADE}

A informação desta pesquisa ficará privado e protegido à extensão completa da lei. A informação não interpretada estará guardado seguramente e só a equipe de pesquisadores terá acesso à informação. A informação de sua entrevista poderá estar repassado para o propósito duma auditoria autorizado pela faculdade ou outros agentes que seguirão as mesma provisões de confidencialidade. Pode ser possível para alguém saber que você participou nesta pesquisa.

\section{COMPENSAÇAO E CUSTOS}

Você não receberá pagamento para sua participação. Você não será responsável por nenhum custo para participar nesta pesquisa.

\section{DIREITO DE RECUSAR OU RETIRAR}

Sua participação nesta pesquisa é voluntario. Você está livre de participar nesta pesquisa ou retirar seu consentimento em qualquer momento da pesquisa. Se você recusar ou não participar, não afeitará qualquer dos benefícios que você merece. Os pesquisadores reservam o direito de retirar você da pesquisa sem seu consentimento se eles sentiram que é a melhor opção.

\section{INFORMAÇAO DE CONTACTO DO PESQUISADOR}

Se tiver dúvidas sobre o propósito, os procedimentos, ou qualquer assunto com relação a esta pesquisa, pode entrar em contato com Bryn Hafemeister na FIU, +1.972.415.9661., be.hafemeister@gmail.com.

\section{INFORMAÇAO DE CONCATO DE IRB}

Se quiser falar com alguém sobre seus direitos de participar numa pesquisa ou sobre assuntos éticos desta pesquisa, pode contatar a Oficina de Integridade de Pesquisa ao FIU ao+305.348.2494 ou por correio eletrônico ao ori@fiu.edu.

\section{CONSENTIMENTO DO PARTICIPANTE}

Eu tenho lido a informação neste formulário de consentimento. Tive a oportunidade de fazer perguntas sobre esta pesquisa, e me responderam. Entendo que mereço uma copia deste formulário após de que estar lido e assinado.

Asignatura do Participante

Nome Escrito do Participante

Asignatura da Pessoa Obtendo o Consentimento
Data

Data 


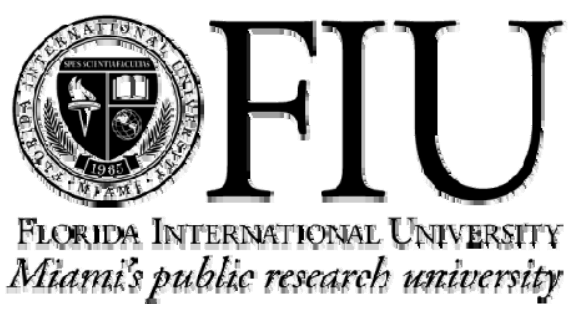

CHILD ASSENT TO PARTICIPATE IN A RESEARCH STUDY

A Critical Ethnography of Youth Development in a Brazilian Favela

\section{WHY ARE YOU DOING THIS STUDY?}

We would like for you to be in a research study that we are doing. A research study is a way to learn information about something. We would like to find out more about how the Morrinho youth communicate their experiences of living in a favela.

\section{HOW MANY OTHERS WILL BE IN THIS STUDY?}

If you agree to participate in this study, you will be one of approximately 14 participants.

\section{HOW LONG WILL THE STUDY LAST?}

Your participation will require between 1 and 2 hours.

\section{WHAT WILL HAPPEN IN THIS STUDY?}

If you participate in this study, we will ask you to do the following things:

1. Hold a conversation and answer some questions about what you want for your artwork to communicate about your daily life.

2. Questions may concern interpreting sections of the documentary film or photos of the Morrinho project.

3. All interviews will be audio and video recorded.

\section{CAN ANYTHING BAD HAPPEN TO ME?}

Some things may make you uncomfortable such as somebody visiting Morrinho, and recognizing you as having participated in this study. The researcher intends on using images of the Morrinho artwork and the film of the interviews for academic purposes only, but this makes it possible for somebody to identify whom you are and that you have participated in this study.

\section{CAN ANYTHING GOOD HAPPEN TO ME?}

Readers of this research may better understand the day-to-day reality of a male youth who lives in a favela in Rio de Janeiro.

\section{DO I HAVE OTHER CHOICES?}

There are no known alternatives available to you other than not taking part in this study. 


\section{WILL ANYONE KNOW I AM IN THE STUDY?}

The raw data of this study will be kept private and will be protected by the researchers, but it may be possible for somebody to find out that you participated in this study.

\section{WILL I BE GIVEN ANYTHING FOR PARTICIPATING?}

You will not receive a payment for participating in this study. You will not need to pay for anything to participate in this study.

\section{WHAT IF I DO NOT WANT TO DO THIS?}

You do not have to be in this study if you don't want to and you can quit the study at any time. If you don't like a question, you don't have to answer it. No one will get mad at you if you decide you don't want to participate.

\section{WHO CAN I TALK TO ABOUT THE STUDY?}

If you have any questions about this research study you may contact Bryn Hafemeister at Florida International University, +1.972.415.9661, be.hafemeister@gmail.com. If you would like to talk with someone about your rights of being a participant in this study, you may contact the FIU Office of Research Integrity by phone at +1.305 .348 .2494 or by email at ori@fiu.edu.

\section{PARTICIPANT AGREEMENT}

This study has been explained to me and I agree to participate.

Signature of Child Participant

Date

Printed Name of Child Participant

Signature of Person Obtaining Consent

Date 


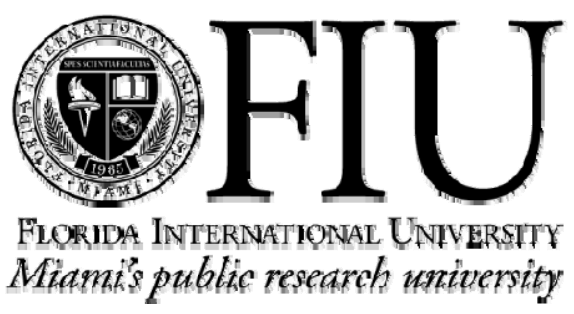

\section{ASSENTIMENTO DE MENOR DE IDADE PARA PARTICIPAR NUMA PESQUISA}

Uma etnografia crítica de desenvolvimento de jovens numa favela brasileira

\section{PORQUE ESTA PARTICIPANDO NESTA PESQUISA?}

Gostaríamos que você participasse na pesquisa que estamos fazendo. Uma pesquisa é uma maneira de aprender de algo. Gostaríamos de saber mais sobre como os jovens de Morrinho comunicam suas experiências diárias de viver numa favela.

\section{QUANTOS OUTRAS ESTARAO NESTA PESQUISA?}

Se assentir participar nesta pesquisa, você será um de aproximadamente 14 participantes.

\section{QUANTO TEMPO VAI DURAR ESTA PESQUISA?}

Sua participação exigirá entre uma e duas horas de seu tempo.

\section{O QUE VAI ACONTECER NESTA PESQUISA?}

Se você participar nesta pesquisa, vamos pedir que você faz o seguinte:

1. Responder uma perguntas e conversar sobre o que você quer que sua maquete de Morrinho comunique de sua vida diária.

2. As perguntas podem haver com sua interpretação de parte do documentário de Morrinho ou fotos de Morrinho.

3. Todas as entrevistas serão gravados com áudio e vídeo.

\section{ALGO RUIM PODE ACONTECER A MIM?}

Algumas coisas podem te fazer sentir incômodo como alguém visitar Morrinho e reconhecer você como um participante deste pesquisa. A pesquisadora tem a intenção de usar os imagens da maquete de Morrinho e filme das entrevistas para propósitos acadêmicos, e isto faz possível para alguém te identificar como participante desta pesquisa.

\section{ALGO BOM PODE ME ACONTECER?}

Pessoas que leem esta pesquisa podem compreender melhor a realidade diária de um jovem que vive numa favela no Rio de Janeiro.

TENHO OUTRAS OPÇOES?

Não tem opções alternativas, mas você não precisa participar na pesquisa. 


\section{ALGUEM VAI SABER QUE PARTICIPEI NEST PESQUISA?}

A informação não interpretada ficará privado e protegido pelos pesquisadores, mas será possível para alguém interar-se que você participou nesta pesquisa.

\section{VOU RECEBER ALGO POR PARTICIPAR?}

Você não receberá nada por participar nesta pesquisa. Você não precisará pagar por nada para participar nesta pesquisa.

\section{O QUE SUCEDE SE NAO QUERO FAZER ISTO?}

Você não precisa participar nesta pesquisa se não quiser e pode para à qualquer momento. Se não gosta de uma pergunta, não precisa responder. Ninguém ficará bravo se você decidir que não quer participar.

\section{COM QUEM POSSO FALAR SOBRE ESTA PESQUISA?}

Se você tiver perguntas sobre esta pesquisa, pode contatar Bryn Hafemeister na Florida International University, +1.972.415.9661, be.hafemeister@gmail.com. Se quiser falar com alguém sobre seus direitos, pode contatar a Oficina de Integridade de Pesquisa de FIU por telefone ao +1.305.348.2494 ou por correio eletrônico ao ori@fiu.edu.

\section{ASSENTIR DE PARTICIPAR}

Me explicou esta pesquisa e concordo com estar nesta pesquisa.

Assintatura do Participante

Nome do Participante de Menor de Idade

Assinatura da Pessoa Obtendo o Consentimento

\section{Data}

Data 


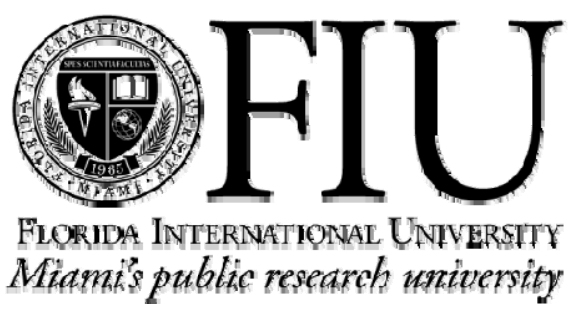

\section{PARENTAL CONSENT TO PARTICIPATE IN A RESEARCH STUDY \\ A Critical Ethnography of Youth Development in a Brazilian Favela}

\section{PURPOSE OF THE STUDY}

You are being asked to give your permission for your child to be in a research study. The purpose of this study is to describe what the Morrinho youth communicate about their experiences of living in a favela through their film, artwork, and words.

\section{NUMBER OF STUDY PARTICIPANTS}

If you agree to allow your child to participate in this study, he/she will be one of approximately 14 people in this research study.

\section{DURATION OF THE STUDY}

Your child's participation will require 1 to 2 hours.

\section{PROCEDURES}

If your child participates in this study, we will ask your child to do the following things: 1. Hold a conversation and answer some questions about Morrinho and what your child means for his artwork to communicate about his daily life.

2. Questions may concern interpreting sections of the documentary film or photos of the Morrinho project.

3. All interviews will be audio and video recorded.

\section{RISKS AND/OR DISCOMFORTS}

The only possible risk of this study is that your child may be identified as having participated in this study due to the public nature of the Morrinho project. The researcher intends on using images of the Morrinho artwork and the film of the interviews for academic purposes only, but this makes it possible for somebody to identify whom your child is and that he has participated in this study.

\section{BENEFITS}

The main desired benefit is for readers of this research to understand the day to day reality of a male youth who lives in a favela in Rio de Janeiro.

\section{ALTERNATIVES}

There are no known alternatives available to your child other than not taking part in this study. 


\section{CONFIDENTIALITY}

Raw data will be sorted securely and only the researcher team will have access to the records. The records of your child's interview may be reviewed for audit purposes by authorized the university or other agents who will be bound by the same provisions of confidentiality. It may be possible for someone to find out that your child participated in this study.

\section{COMPENSATION AND COSTS}

Your child will not receive a payment for participating in this study. Your child will not be responsible for any costs to participate in this study.

\section{RIGHT TO DECLINE OR WITHDRAW}

Your child's participation in this study is voluntary. Your child is free to participate in the study or withdraw his consent at any time during the study. Your child's withdrawal or lack of participation will not affect any benefits to which he is otherwise entitled.

\section{RESEARCHER CONTACT INFORMATION}

If you have any questions about the purpose, procedures, or any other issues relating to this research study you may contact Bryn Hafemeister at FIU, +1.972.415.9661, be.hafemeister@gmail.com.

\section{IRB CONTACT INFORMATION}

If you would like to talk with someone about your child's rights of being a subject in this research study or about ethical issues with this research study, you may contact the FIU Office of Research Integrity by phone at 305-348-2494 or by email at ori@fiu.edu.

\section{PARTICIPANT AGREEMENT}

I have read the information in this consent form and agree to allow my child to participate in this study. I have had a chance to ask any questions I have about this study, and they have been answered for me. I understand that I am entitled to a copy of this form after it has been read and signed.

Signature of Parent/Guardian

Date

Printed Name of Parent/Guardian

Printed Name of Parent/Guardian

Signature of Person Obtaining Consent

Date 


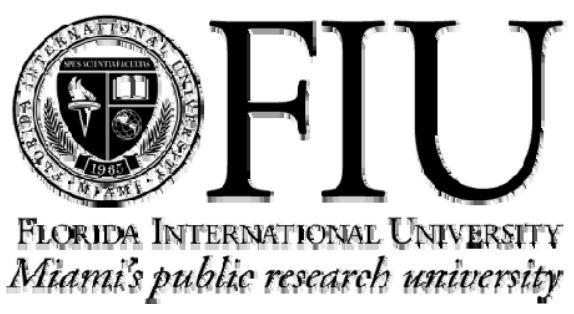

CONSENTIMENTO DE PADRE PARA PARTICIPAR NUMA PESQUISA

Uma etnografia crítica de desenvolvimento de jovens numa favela brasileira

\section{PROPOSTA DA PESQUISA}

Estamos pedindo permissão para seu filho participar nesta pesquisa. A proposta da pesquisa é descrever o que os jovens de Morrinho comunicam da suas experiências de viver numa favela através do filme documentário, a maquete de Morrinho, e as palavras dos jovens.

\section{NUMERO DE PARTICIPANTES DA PESQUISA}

Se decidir deixar seu filho participar nesta pesquisa, ele será um de aproximadamente 14 pessoas na pesquisa.

\section{DURAÇAO DA PESQUISA}

A participação de seu filho exigirá entre uma e duas horas de tempo.

\section{PROCEDIMENTOS}

Se seu filho participar nesta pesquisa, pediremos que ele faça o seguinte:

1. Responder algumas perguntas e conversar sobre Morrinho e o que a maquete e a brincadeira querem comunicar da vida diária dele.

2. A perguntas podem haver com sua interpretação de seu filho de secções do filme documentário ou fotos da maquete de Morrinho.

3. Todas as entrevistas serão gravados com áudio e vídeo.

\section{RISCO E/OU DESCONFORTOS}

O único risco possível desta pesquisa é que devido `a publicidade que recebe Morrinho, alguém poderá identificar você como participante desta pesquisa. A pesquisadora tem a intenção de usar os imagens da maquete de Morrinho e filme das entrevista para propósitos acadêmicos, e isto faz possível para alguém te identificar como participante desta pesquisa.

\section{BENEFICIOS}

O principal beneficio desejado para os leitores desta pesquisa é compreender a realidade diária de um jovem que vive numa favela no Rio de Janeiro.

\section{ALTERNATIVOS}

Não tem opções alternativas, mas você não precisa participar na pesquisa. 


\section{CONFIDENCIALIDADE}

A informação não interpretada estará guardado seguramente e só a equipe de pesquisadores terá acesso à informação. A informação de sua entrevista de seu filho poderá estar repassado para o propósito duma auditoria autorizado pela faculdade ou outros agentes que seguirão as mesma provisões de confidencialidade. Pode ser possível para alguém saber que seu filho participou nesta pesquisa.

\section{COMPENSAÇAO E CUSTOS}

Seu filho não receberá pagamento para a participação dele. Seu fillho não será responsável por nenhum custo para participar nesta pesquisa.

\section{DIREITO DE RECUSAR OU RETIRAR}

A participação de seu filho nesta pesquisa é voluntario. Seu filho está livre de participar nesta pesquisa ou retirar seu consentimento em qualquer momento da pesquisa. Se seu filho recusar ou não participar, não afeitará qualquer dos benefícios que ele merece.

\section{INFORMAÇAO DE CONTACTO DO PESQUISADOR}

Se tiver dúvidas sobre o propósito, os procedimentos, ou qualquer assunto com relação a esta pesquisa, pode entrar em contato com Bryn Hafemeister na FIU, +1.972.415.9661., be.hafemeister@gmail.com.

\section{INFORMAÇAO DE CONCATO DE IRB}

Se quiser falar com alguém sobre seus direitos de participar numa pesquisa ou sobre assuntos éticos desta pesquisa, pode contatar a Oficina de Integridade de Pesquisa ao FIU ao +305.348 .2494 ou por correio eletrônico ao ori@fiu.edu.

\section{CONSENTIMENTO DO PARTICIPANTE}

Eu tenho lido a informação neste formulário de consentimento e concordo que meu filho pode participar nesta pesquisa. Tive a oportunidade de fazer perguntas sobre esta pesquisa, e me responderam. Entendo que mereço uma copia deste formulário após de que estar lido e assinado.

Assinatura do Padre/Guardião

Data

Nome Escrito de Padre/Guardião

Nome Escrito de Menor de Idade

Assinatura da Pessoa Obtendo o Consentimento

Data 
APPENDIX C

Photos Analyzed By Participants

Photo 1

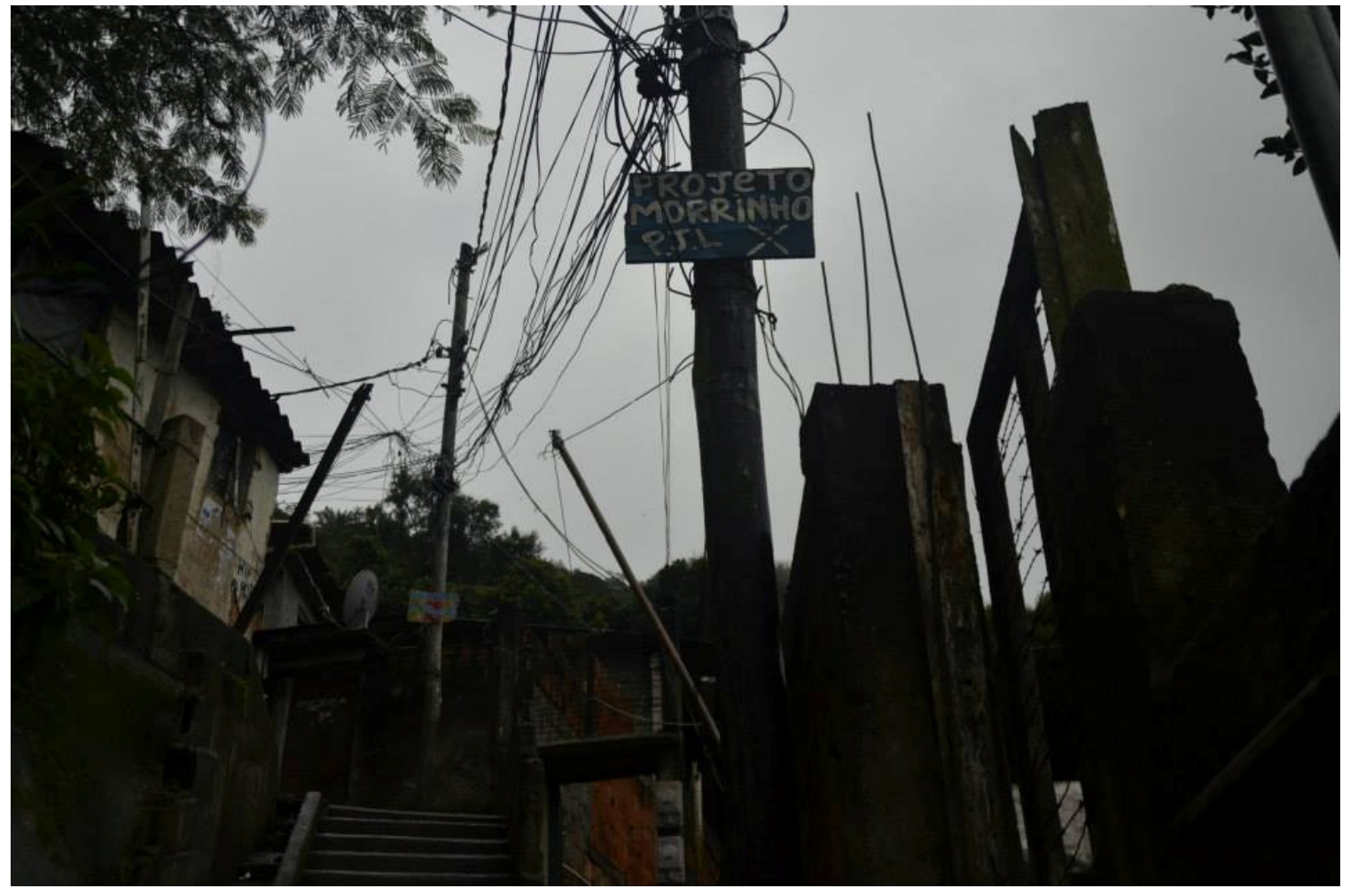




\section{Photo 2}

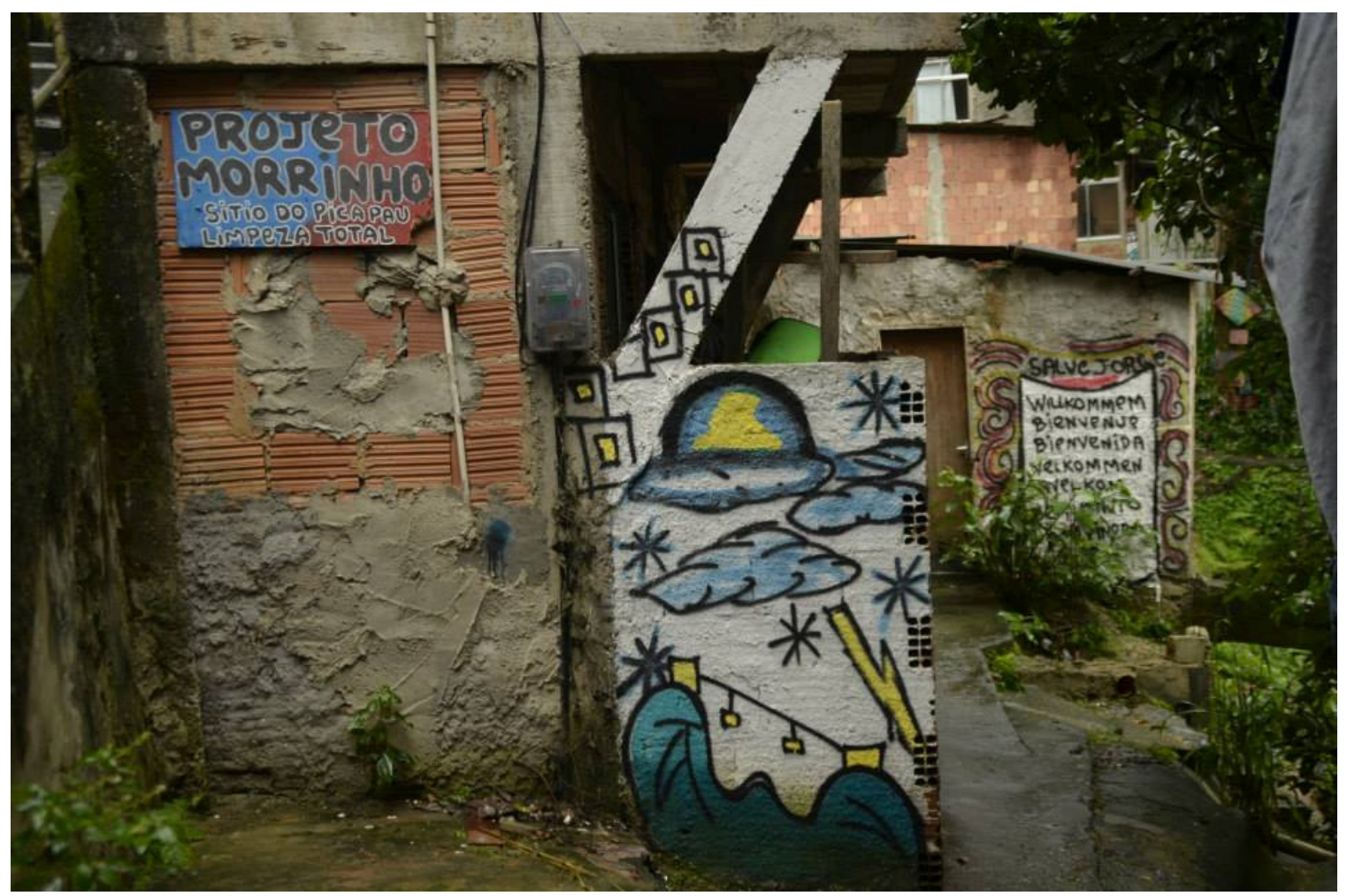


Photo 21

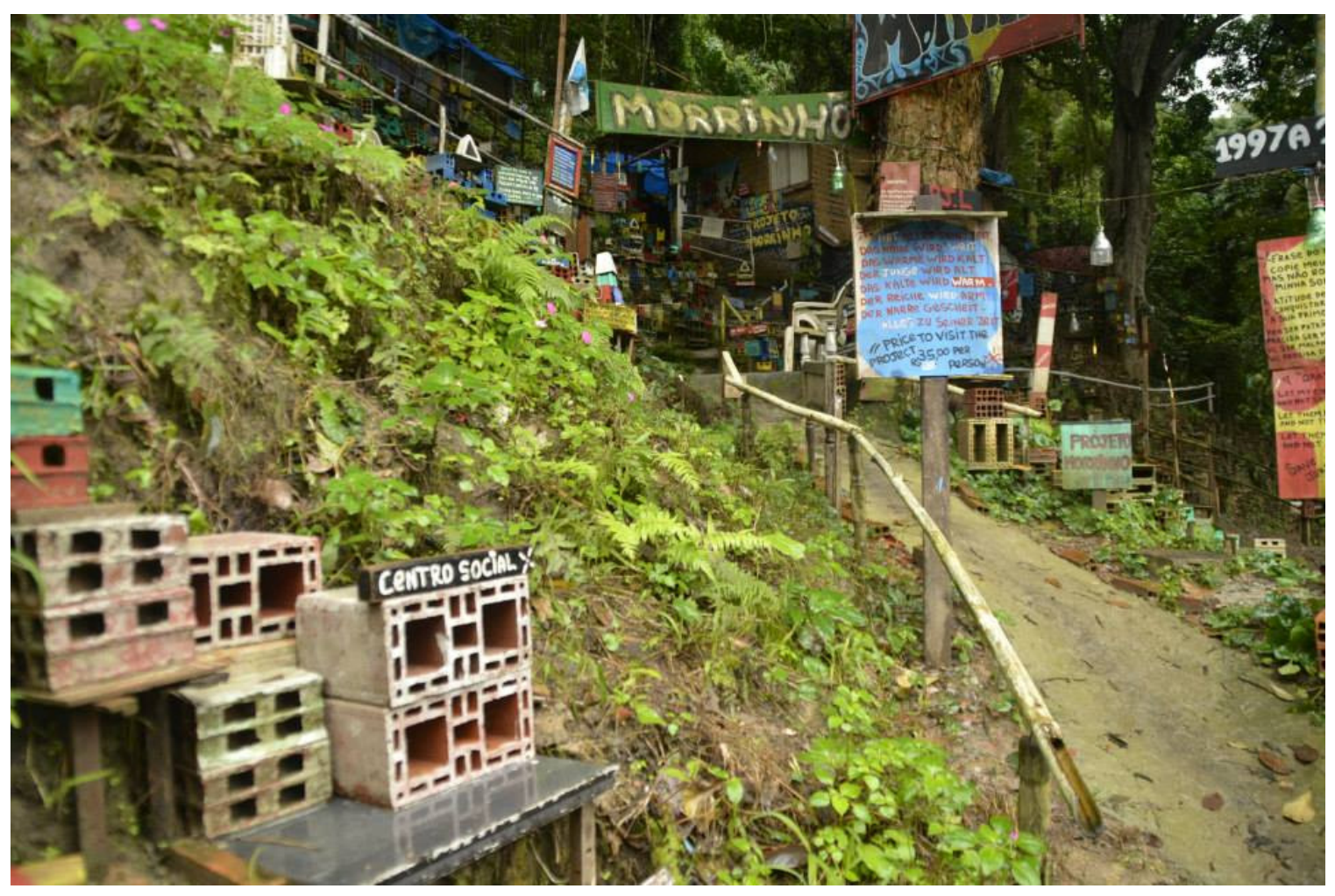


Photo 26

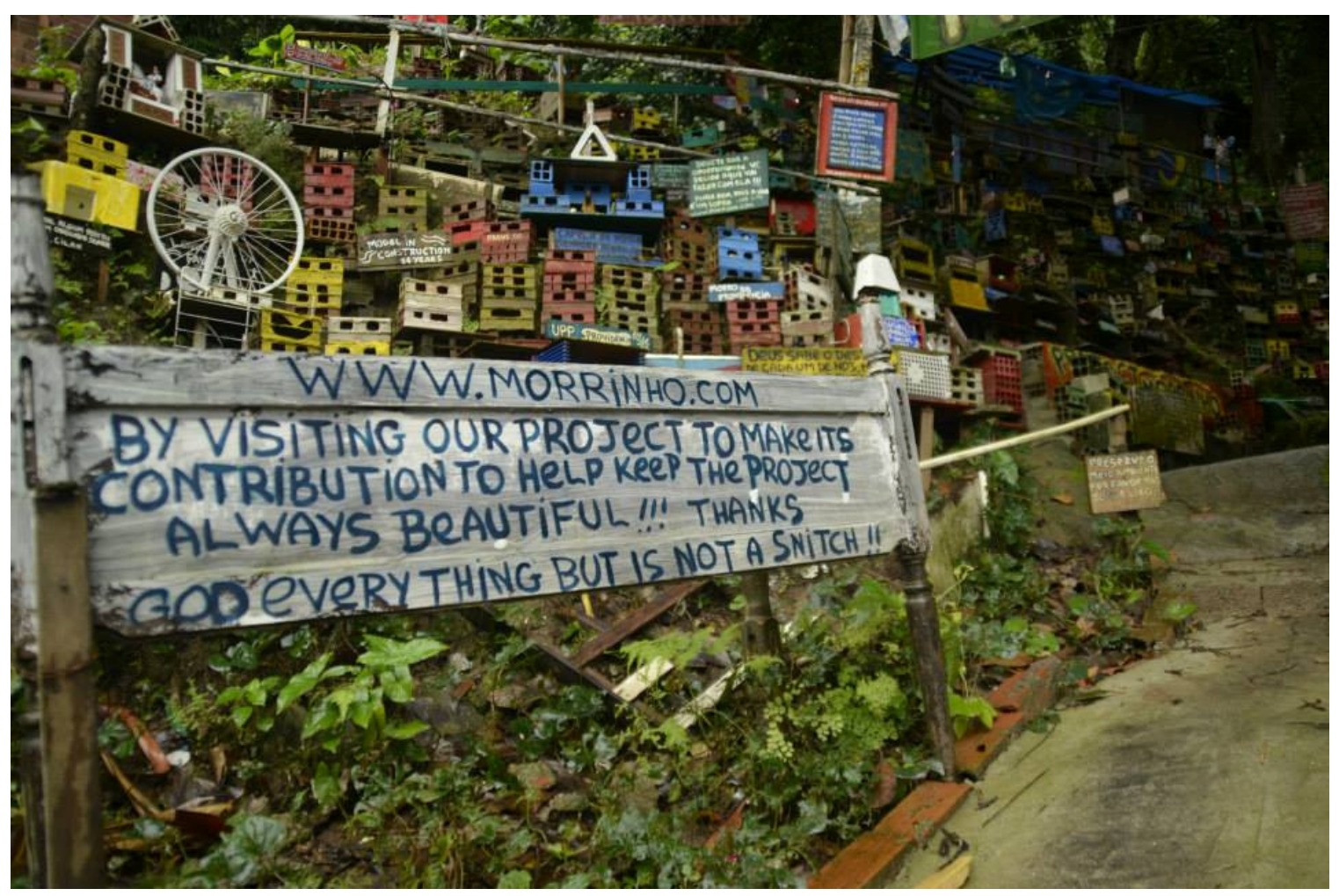


Photo 30

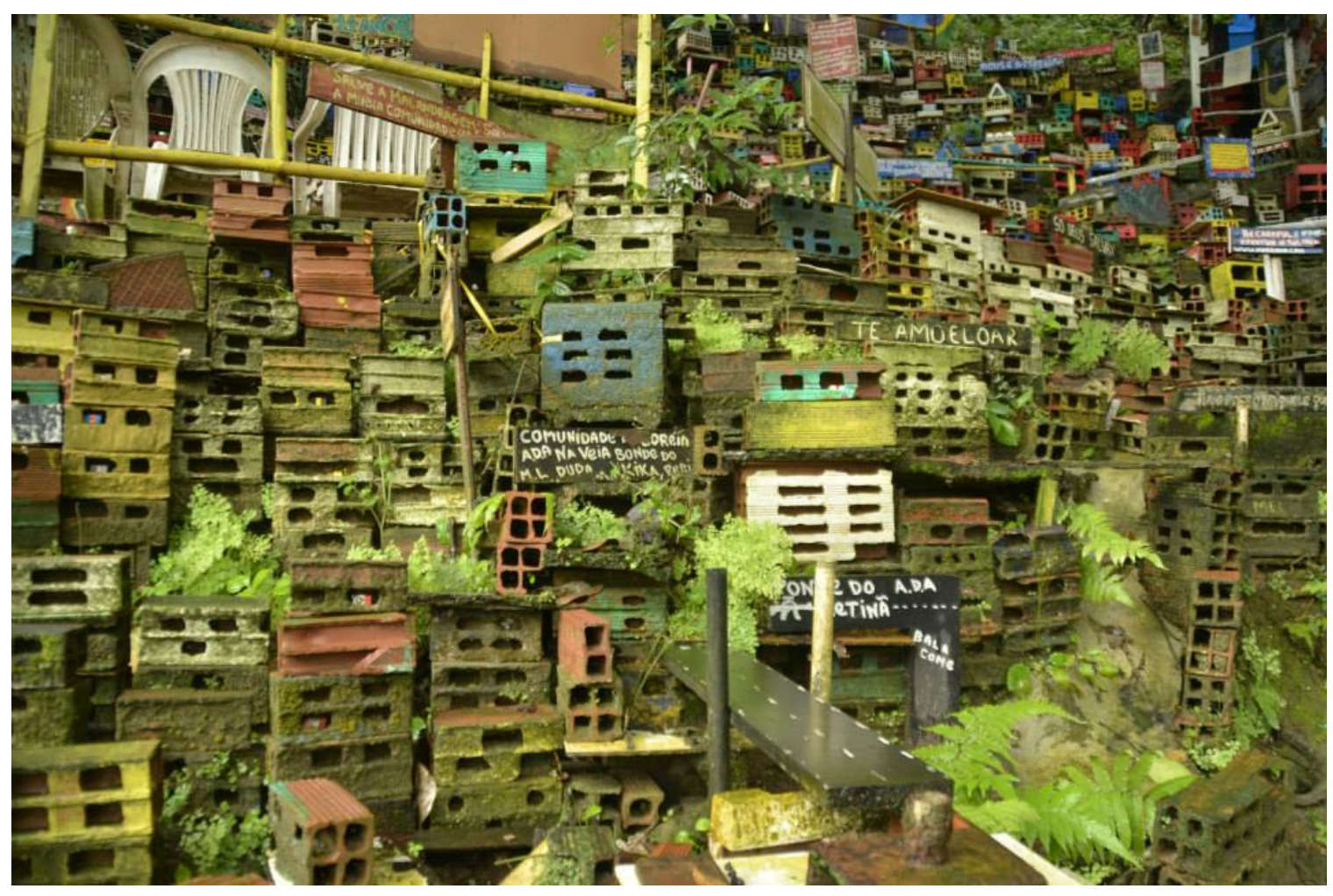


Photo 35

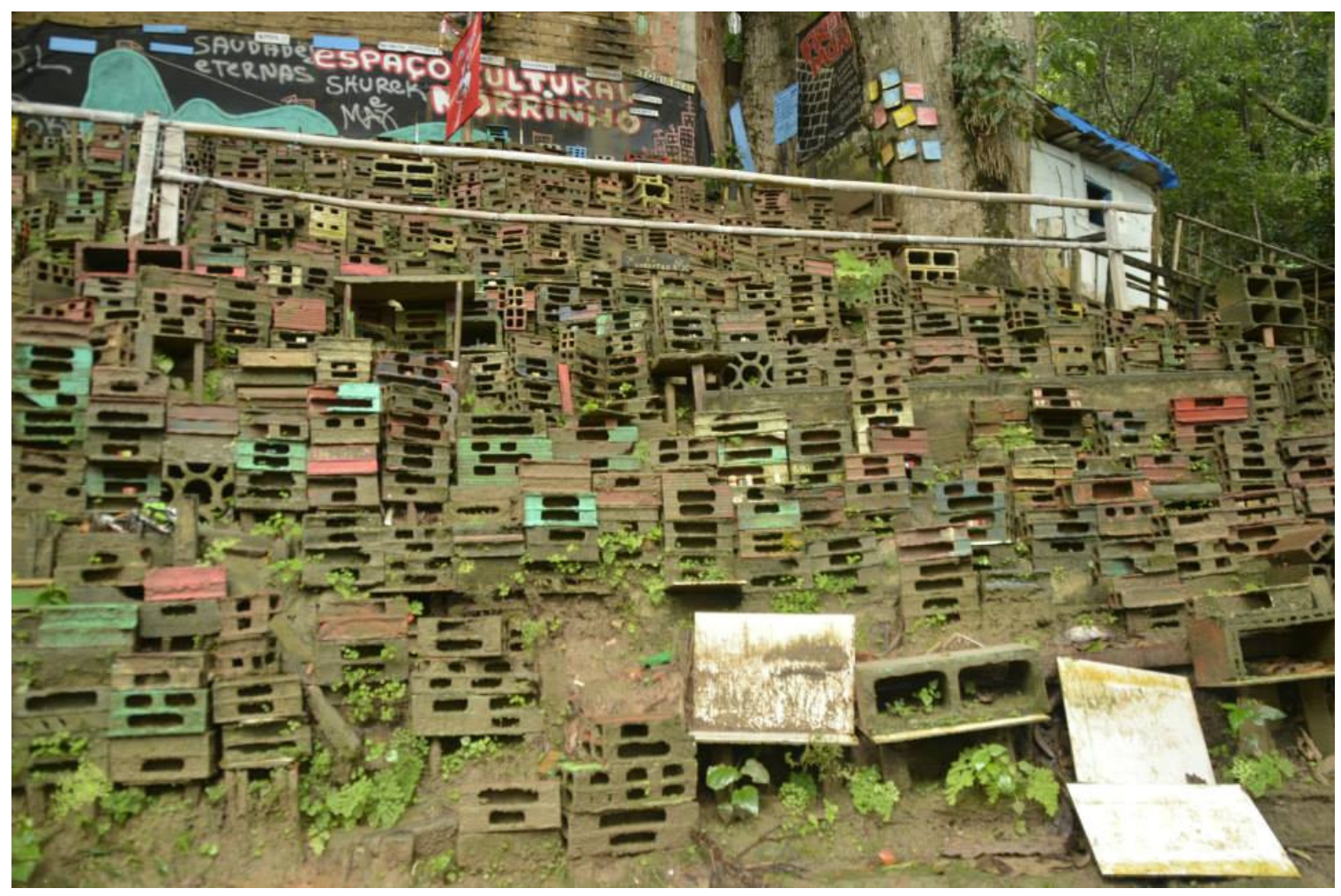


Photo 37

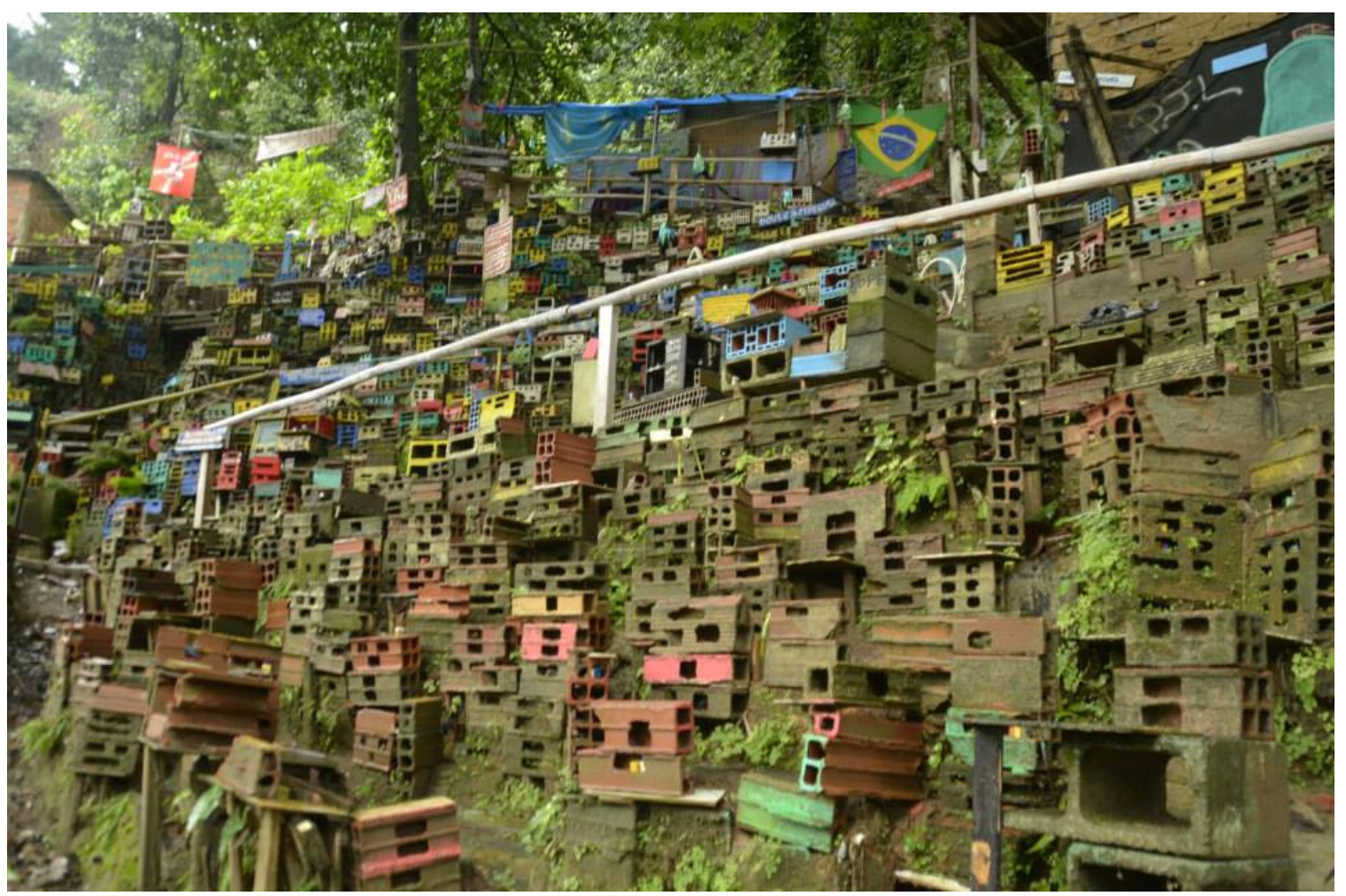


Photo 39

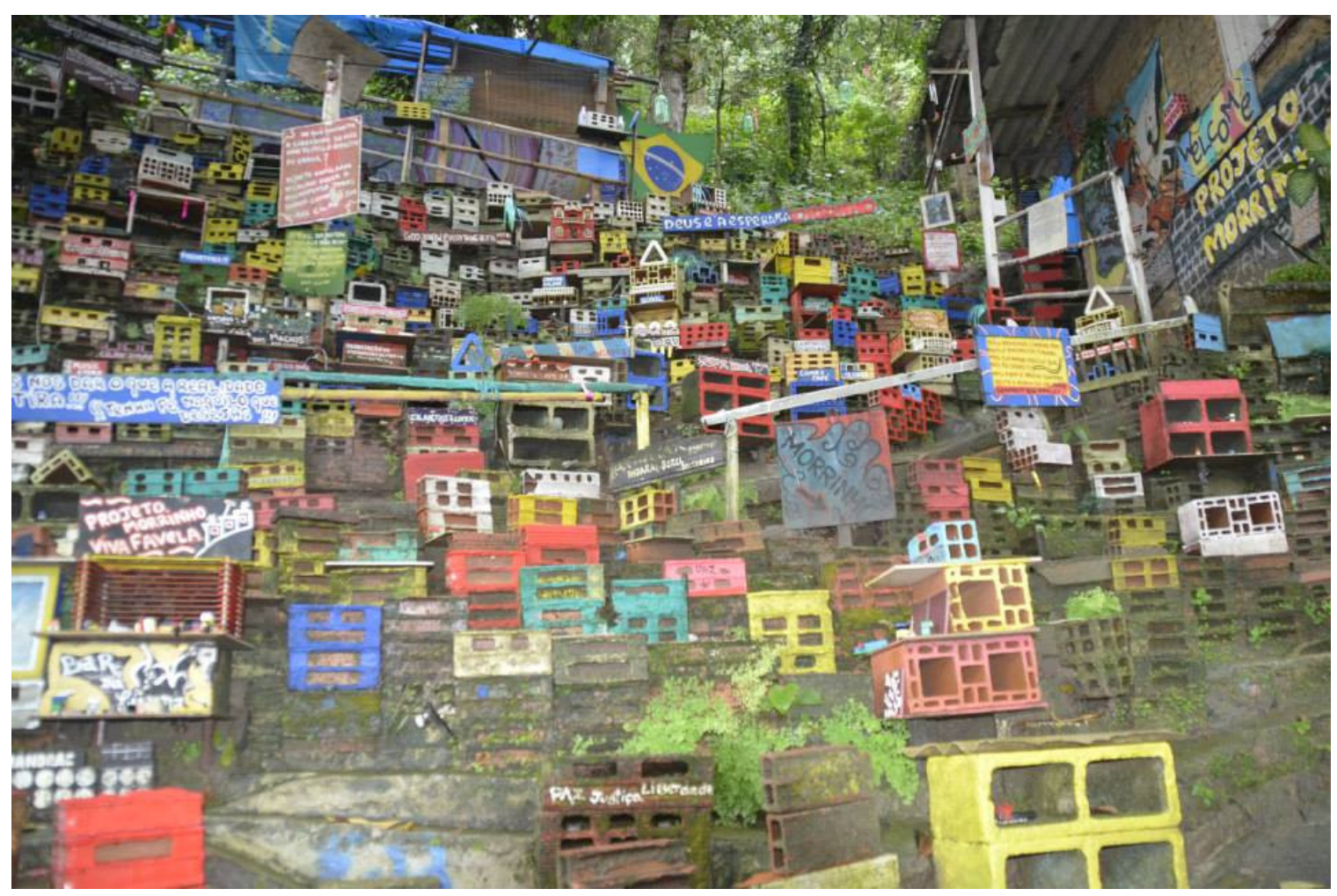


Photo 40

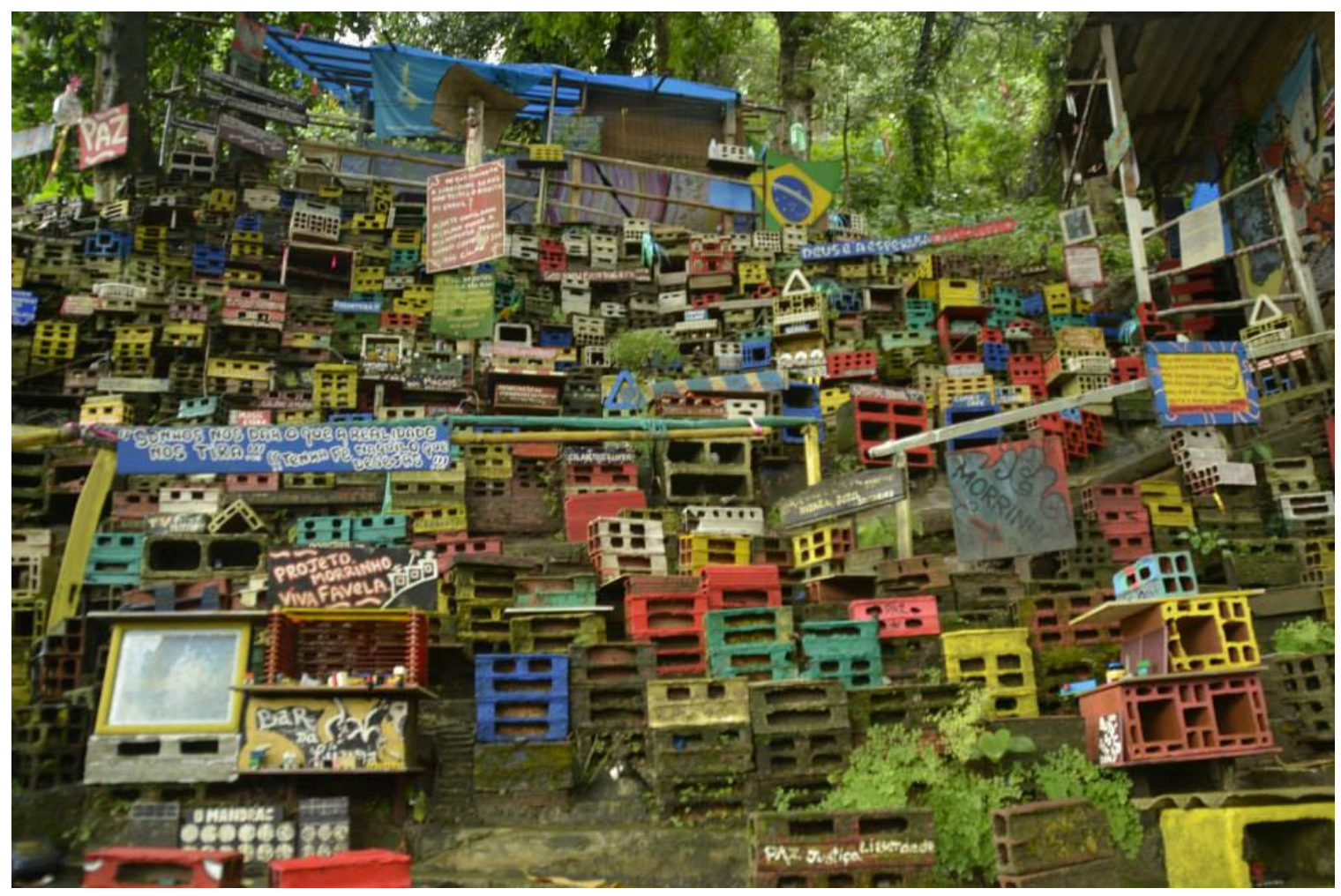


Photo 42

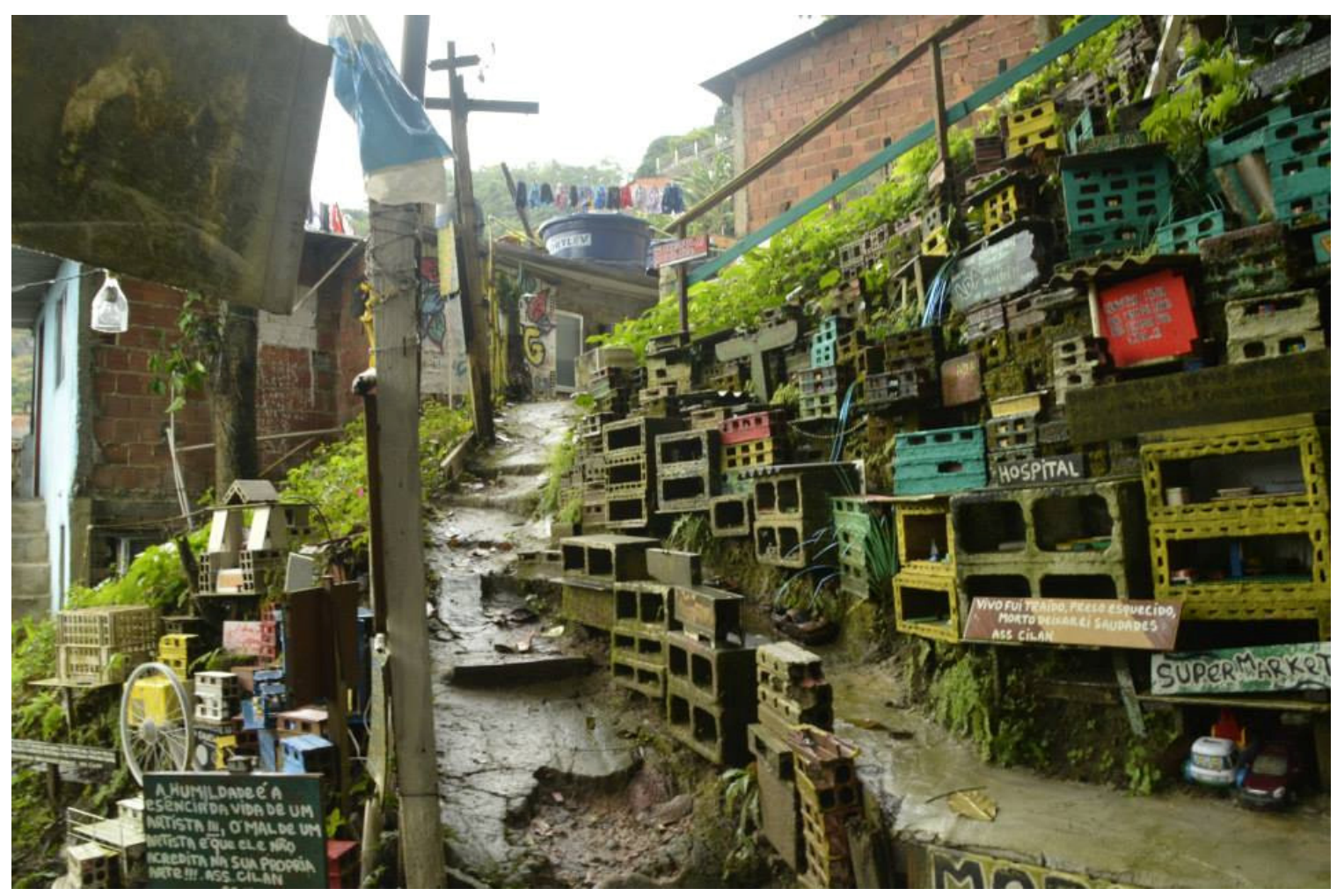


Photo 46

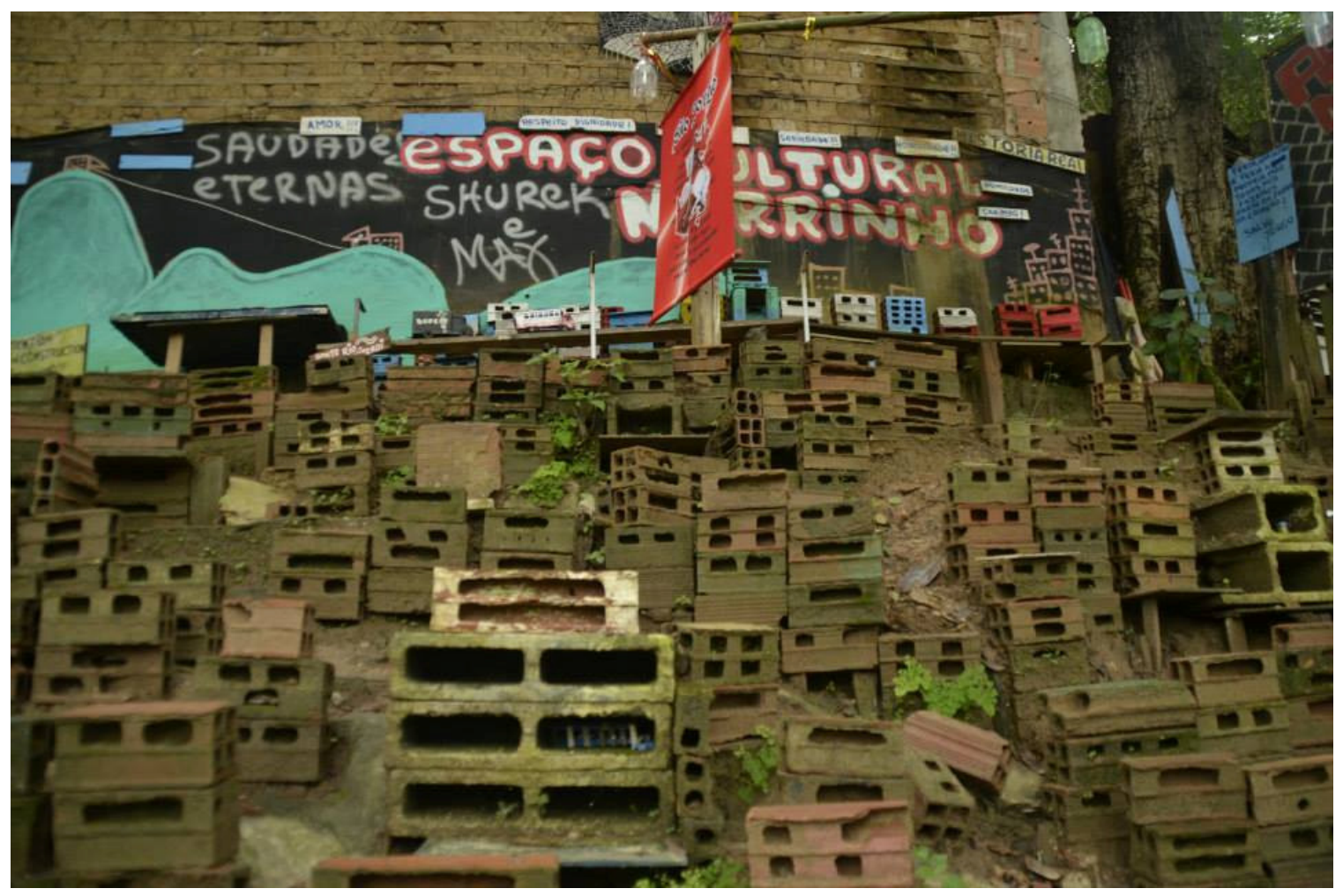




\section{Photo 52}

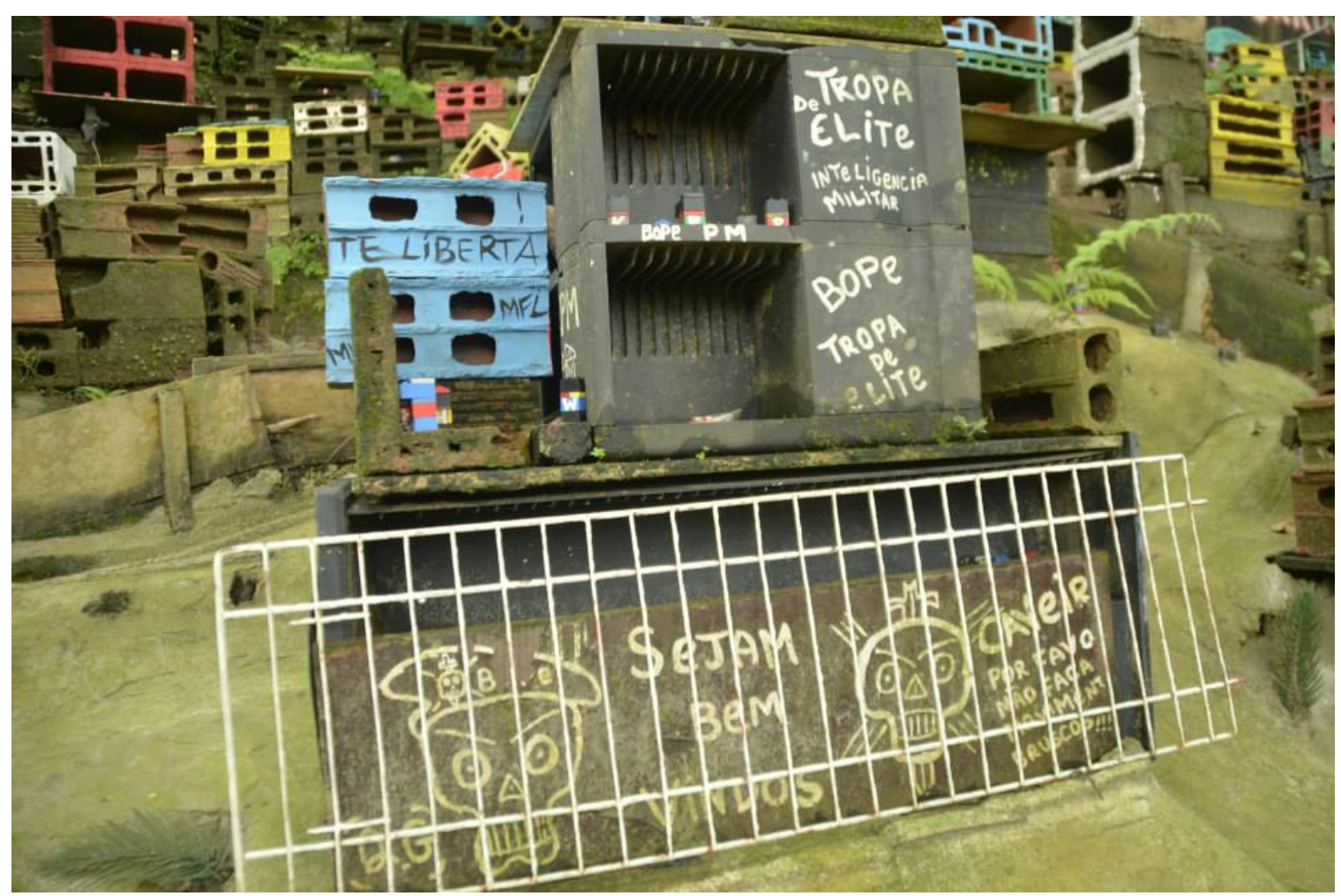


Photo 54

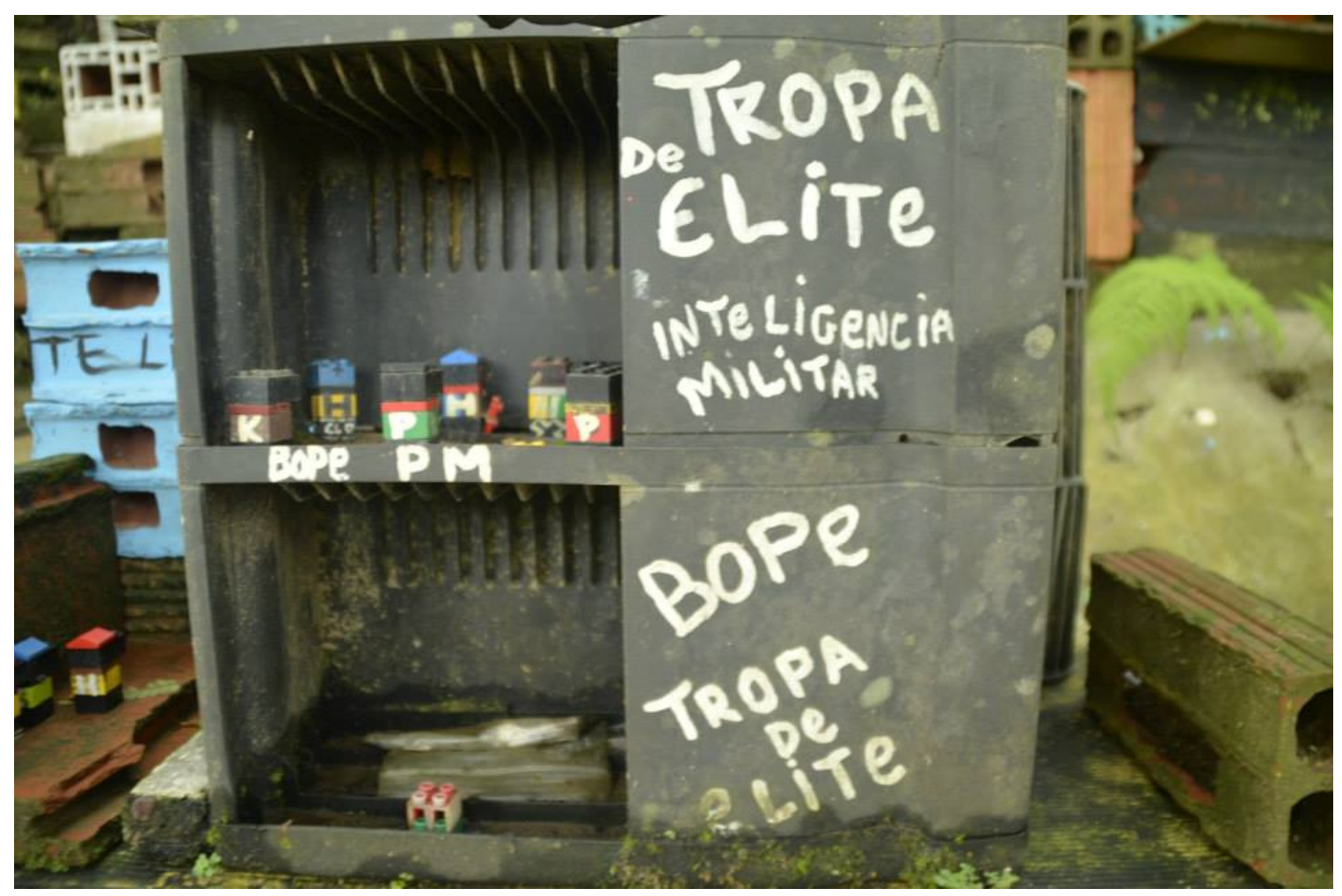




\section{Photo 68}

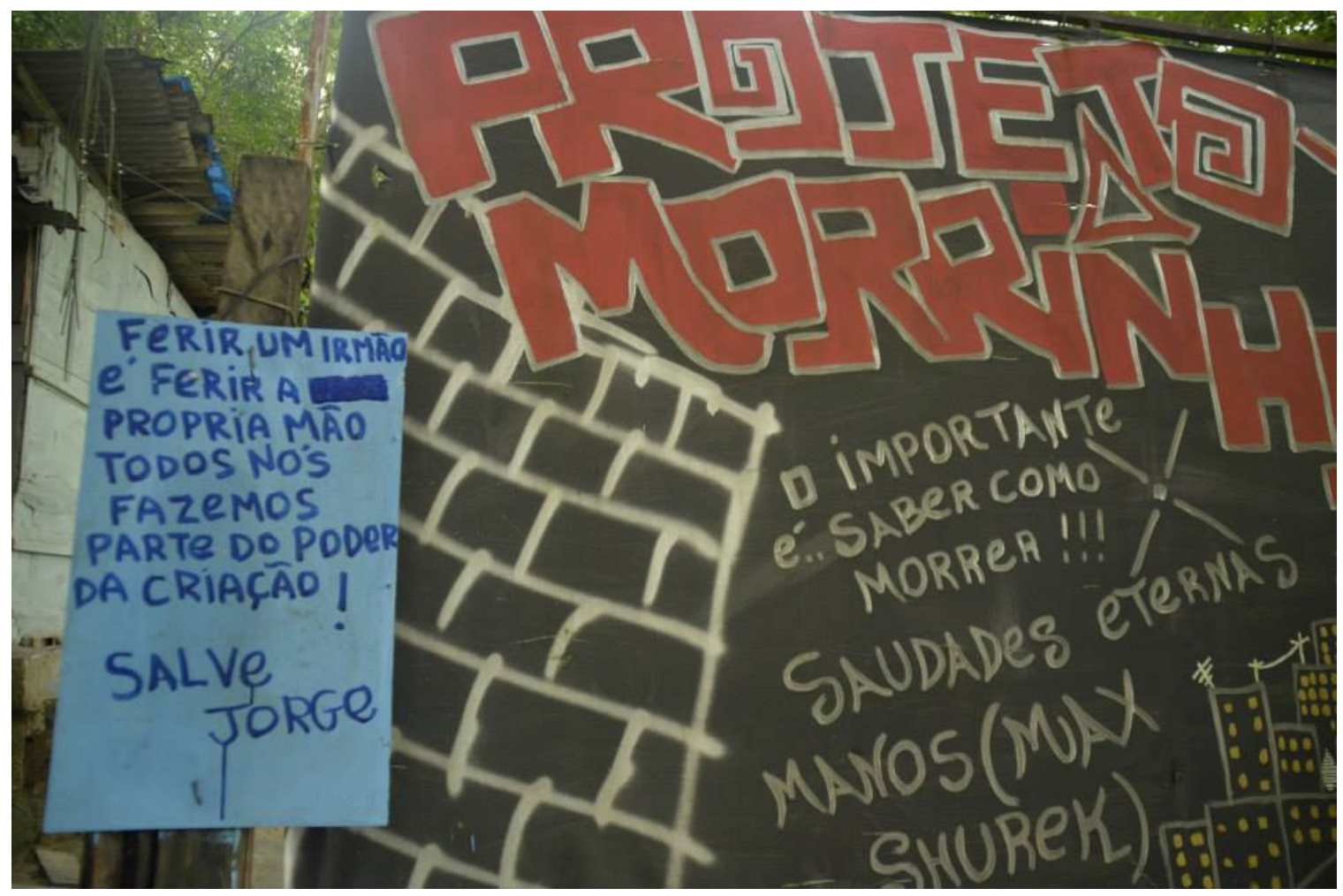


Photo 80

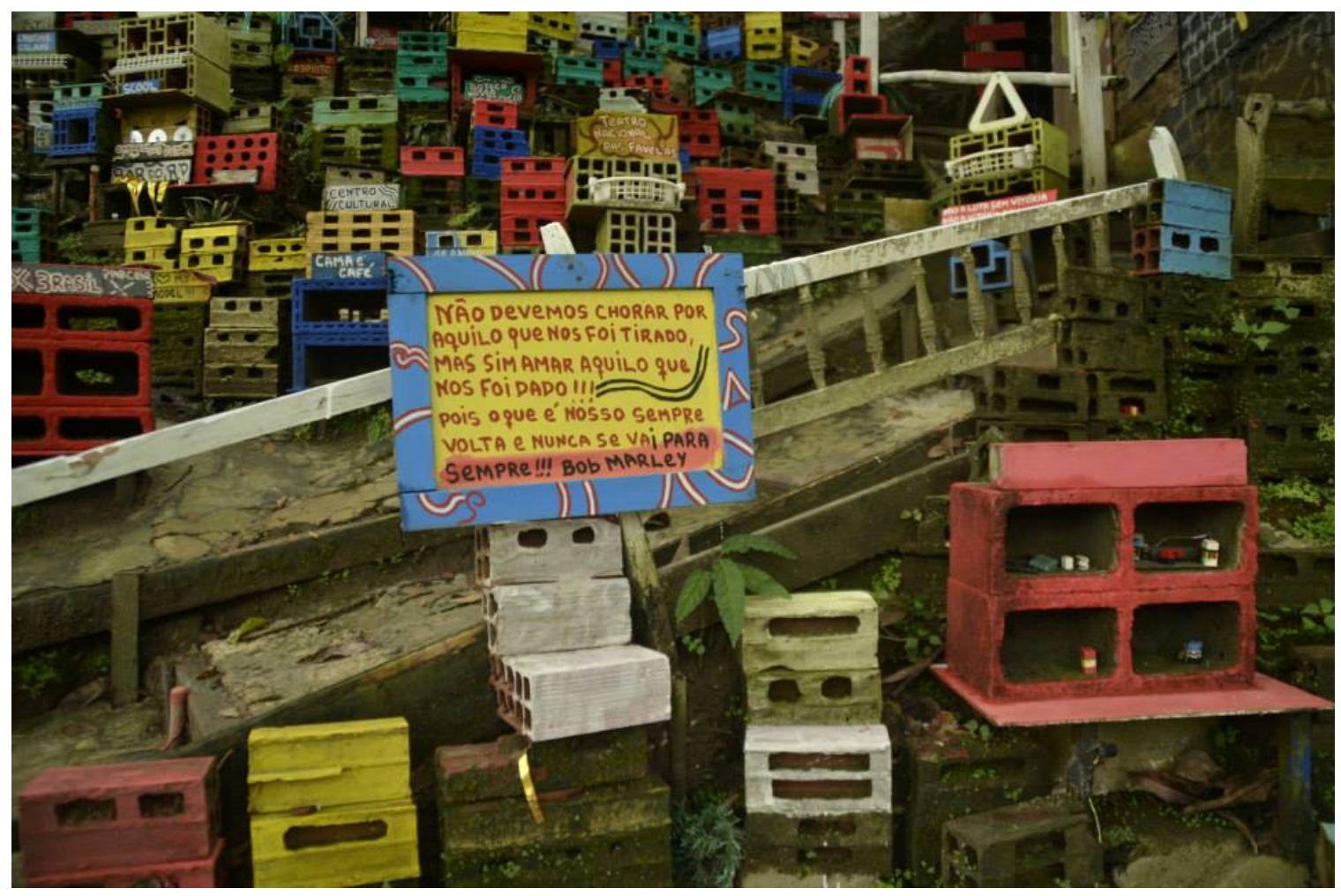




\section{Photo 115}

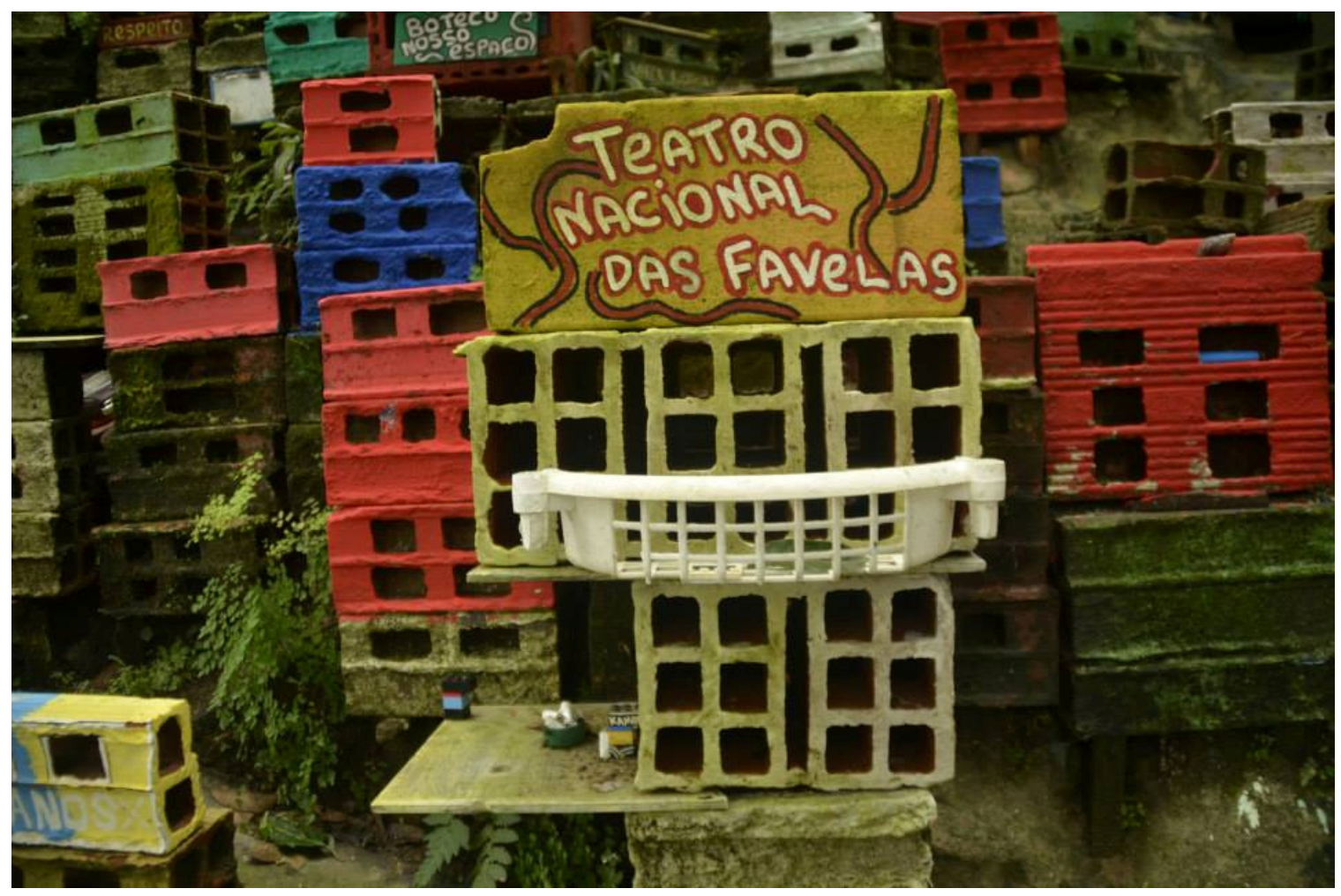


Photo 120

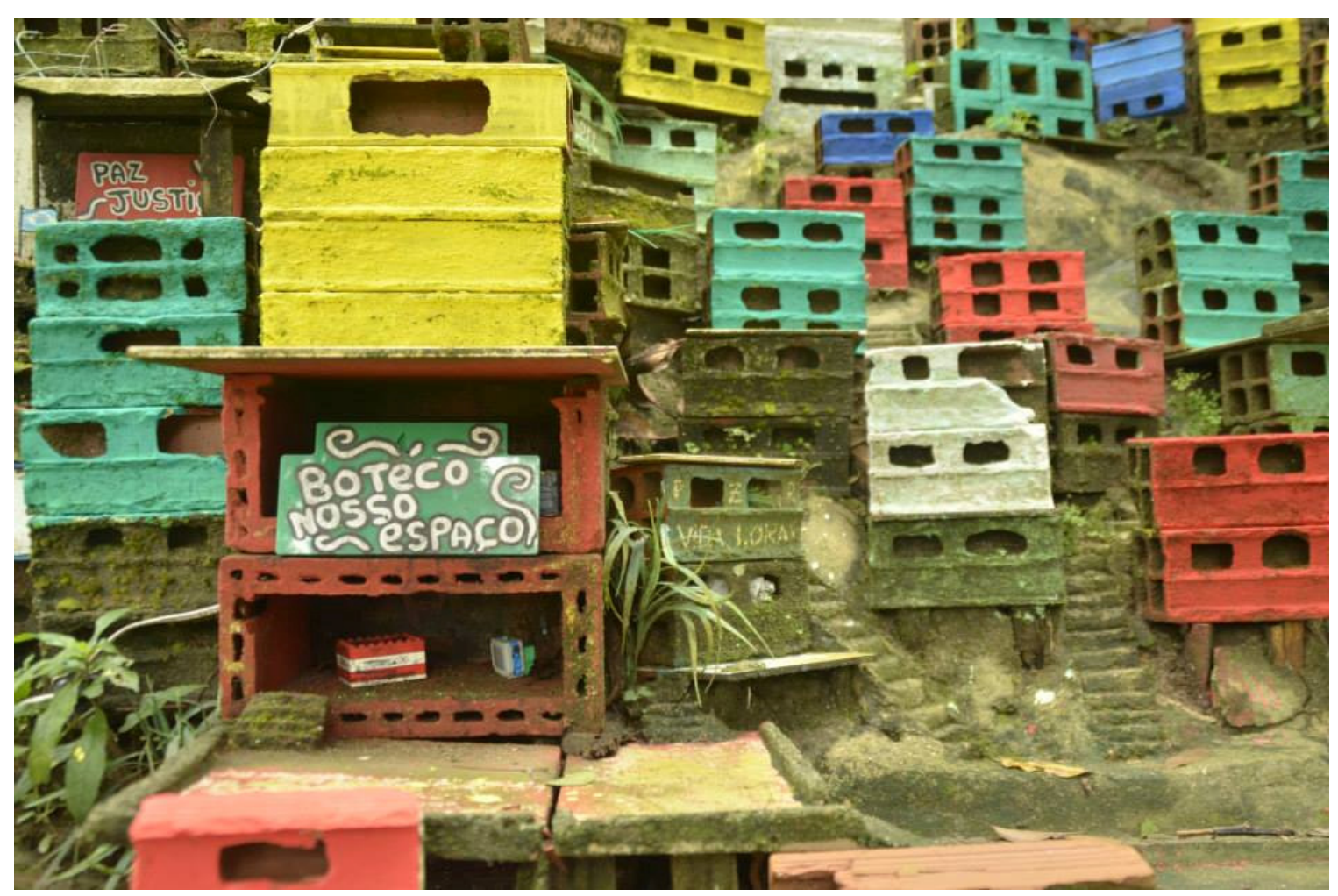


Photo 121

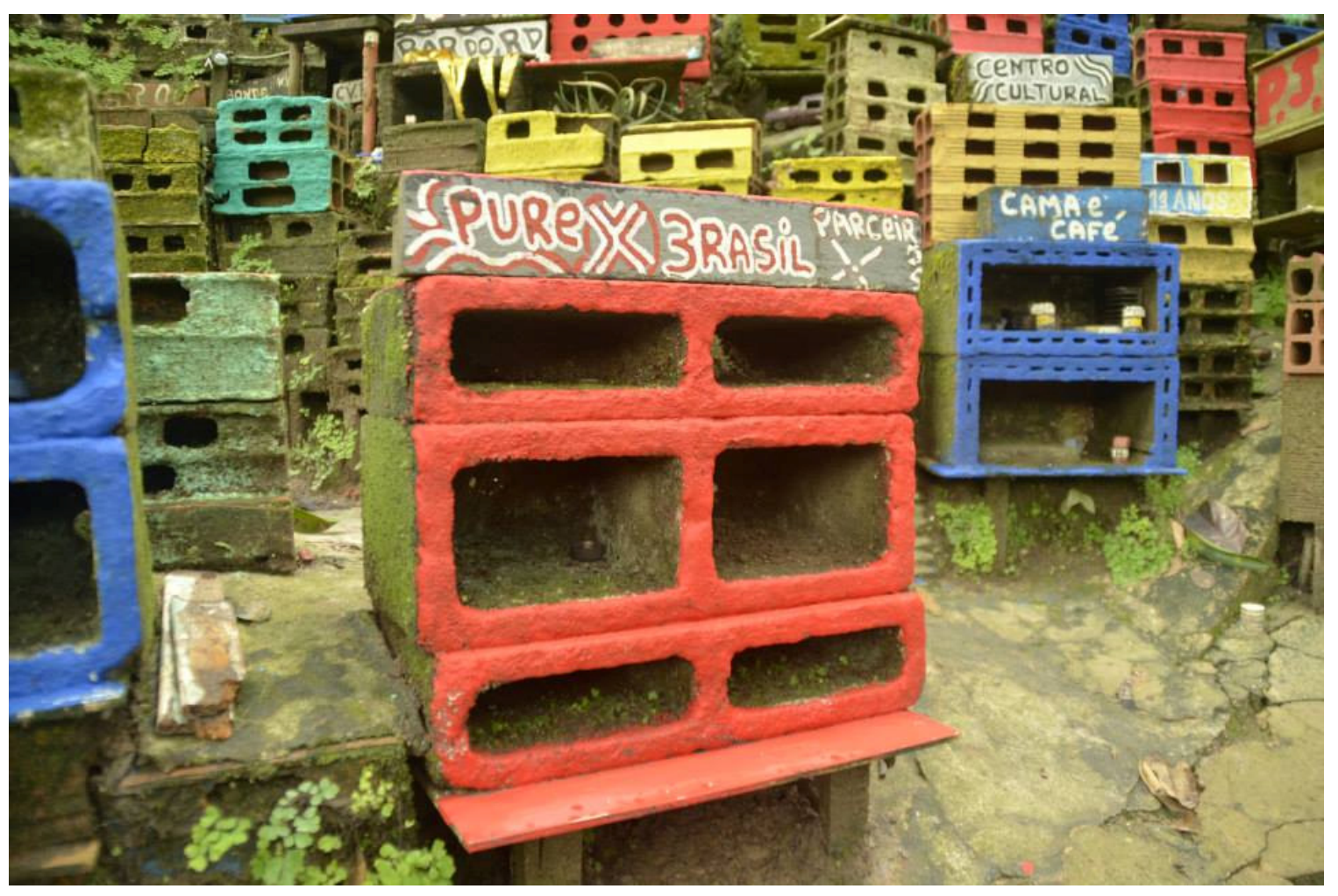


Photo 151

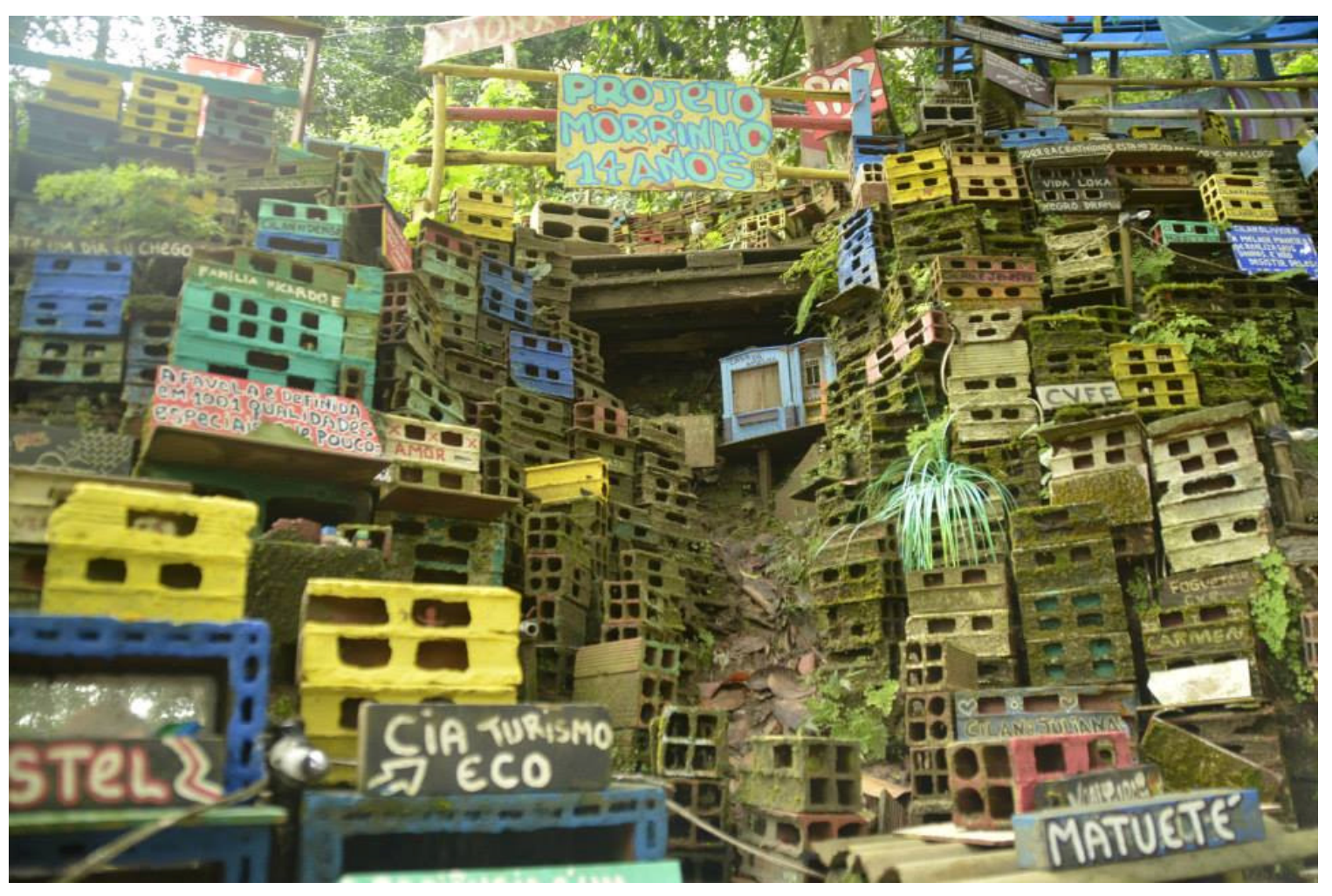


Photo 152

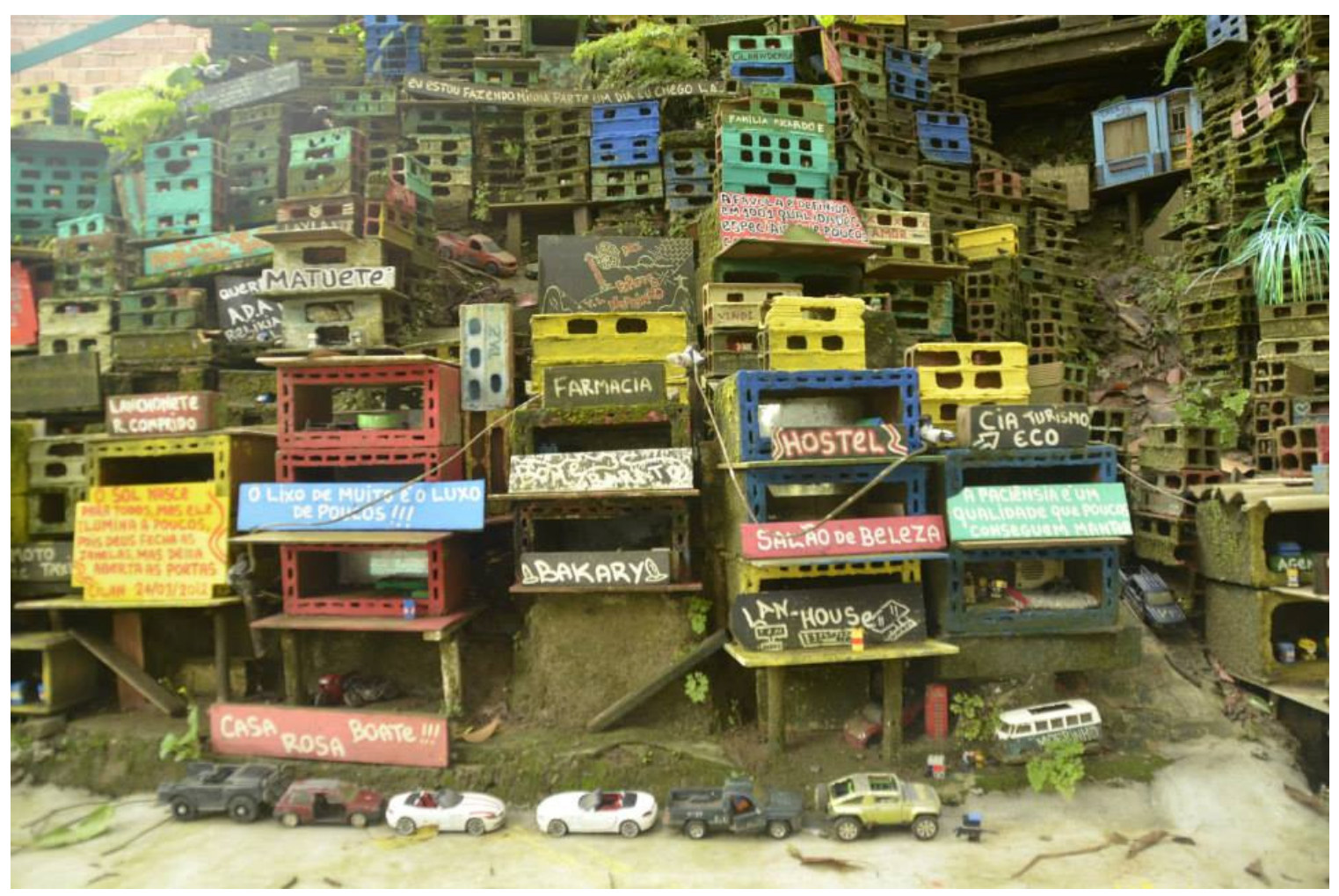


Photo 166

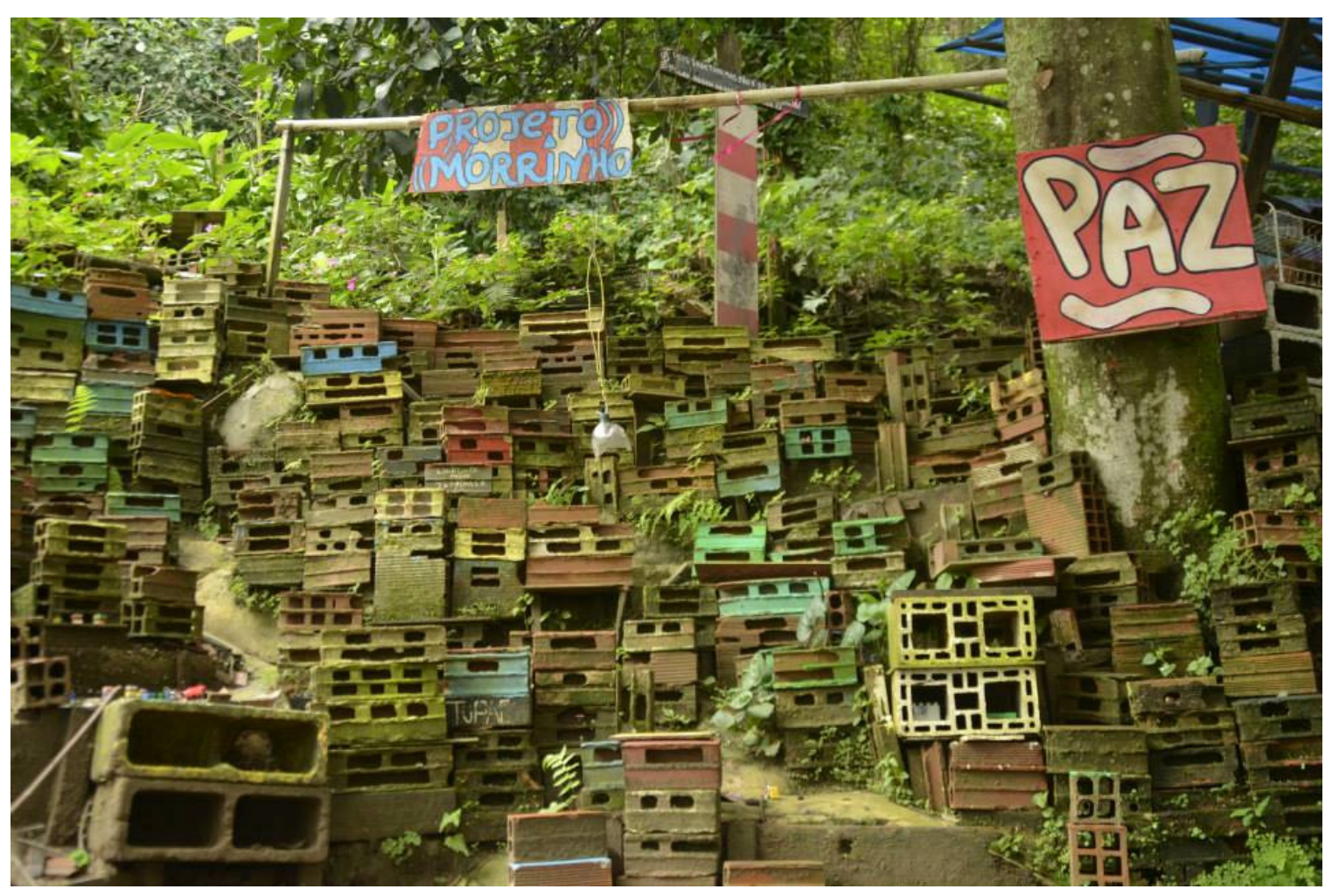


Photo 199

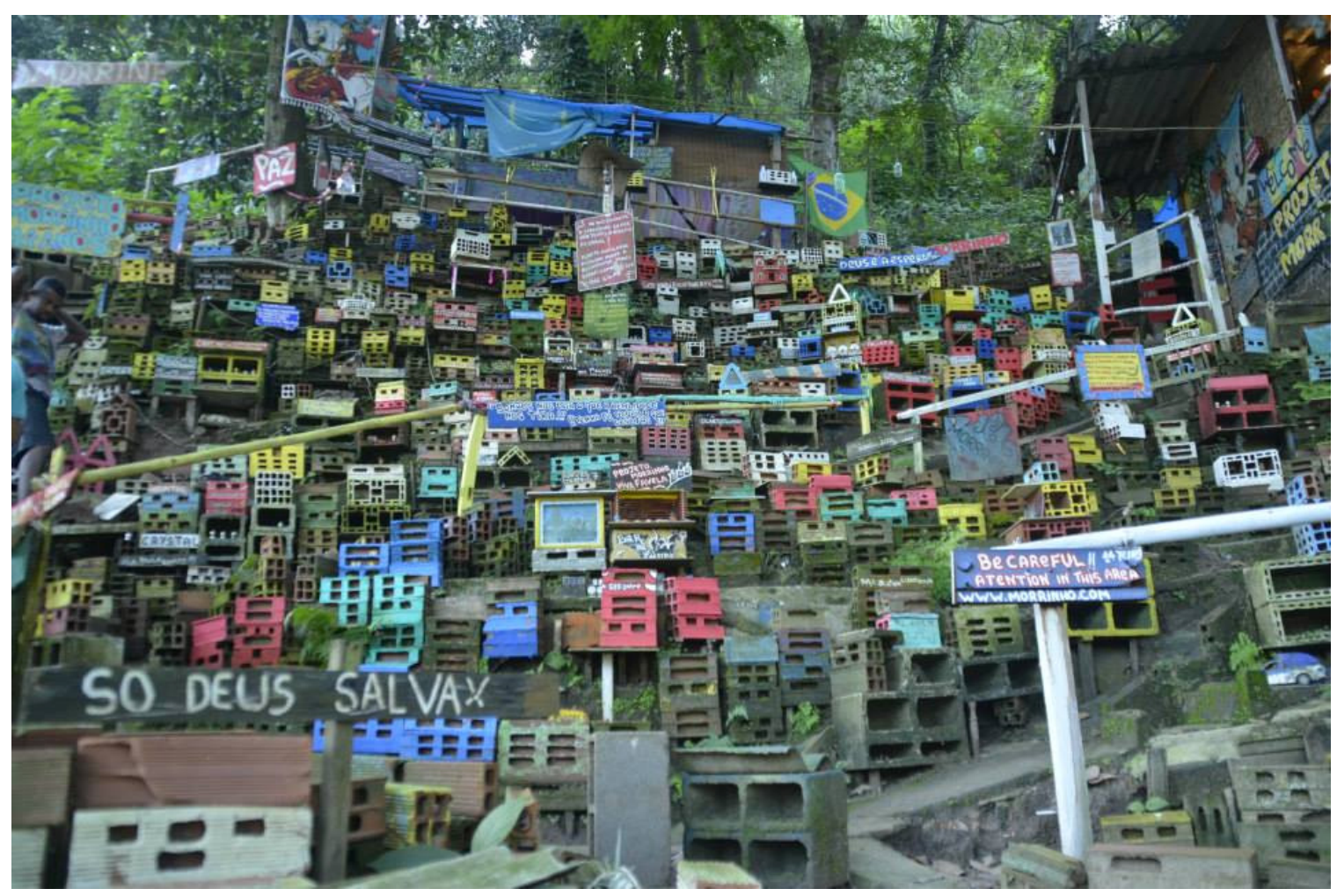


Photo 202

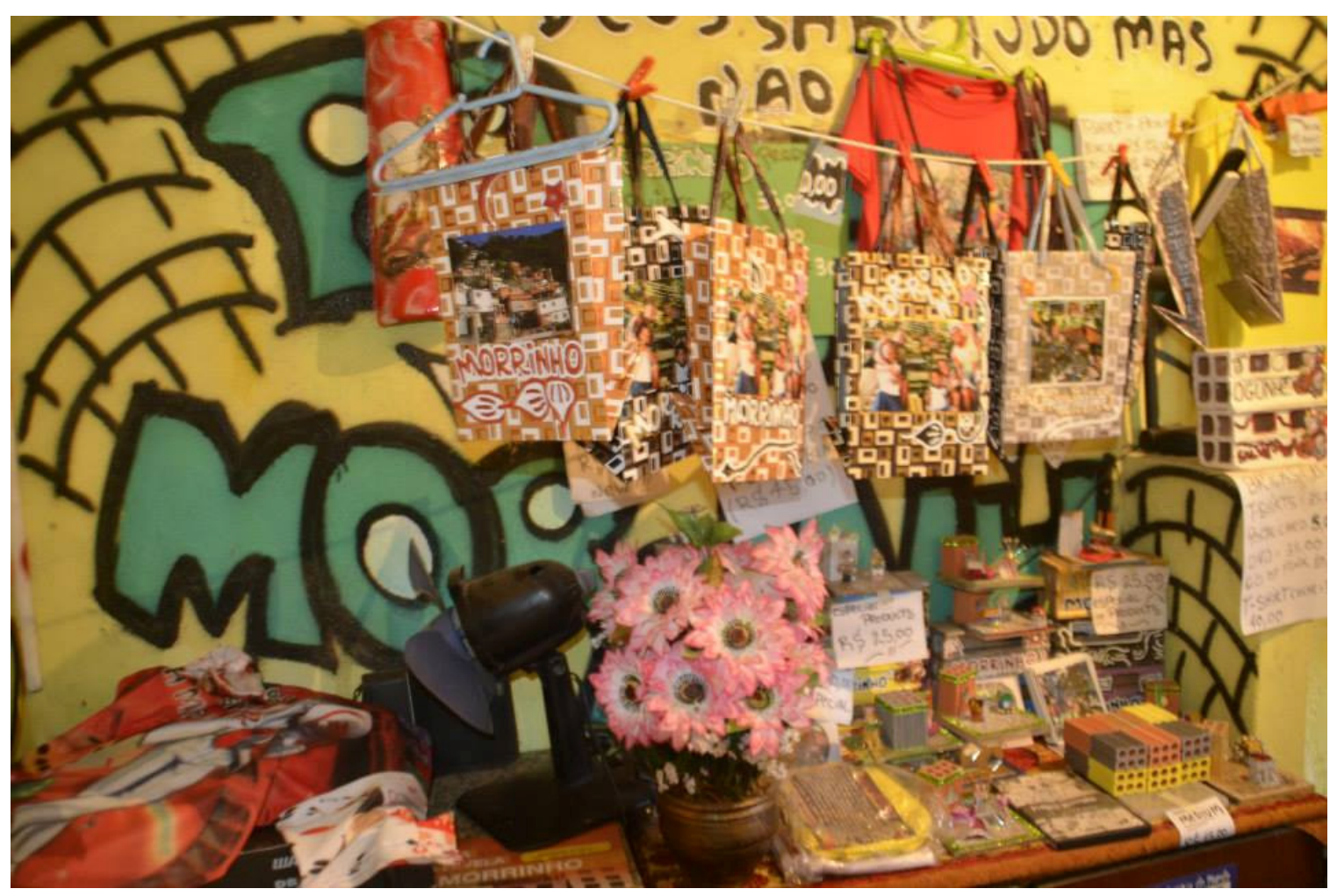


Photo 203

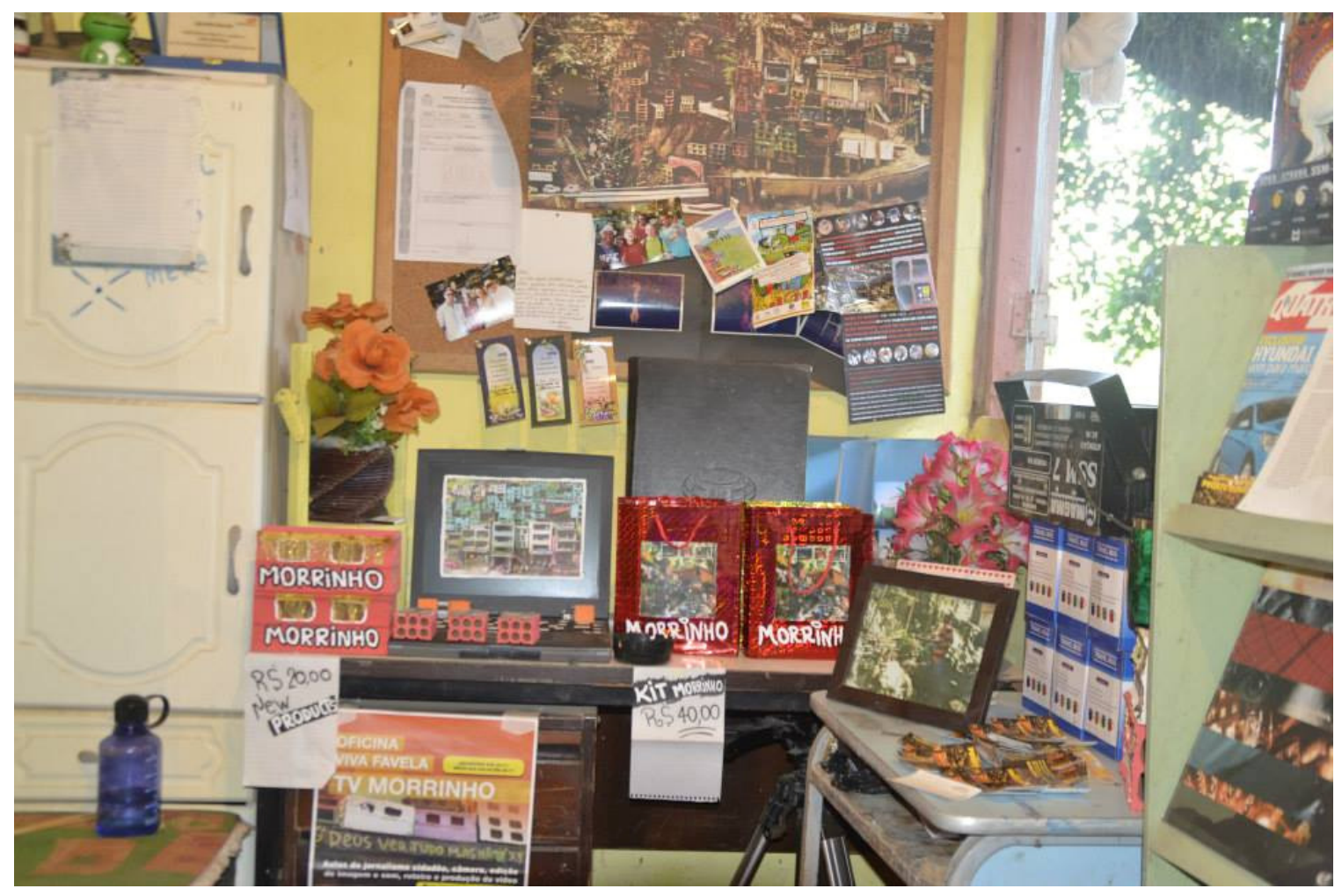


Photo N2

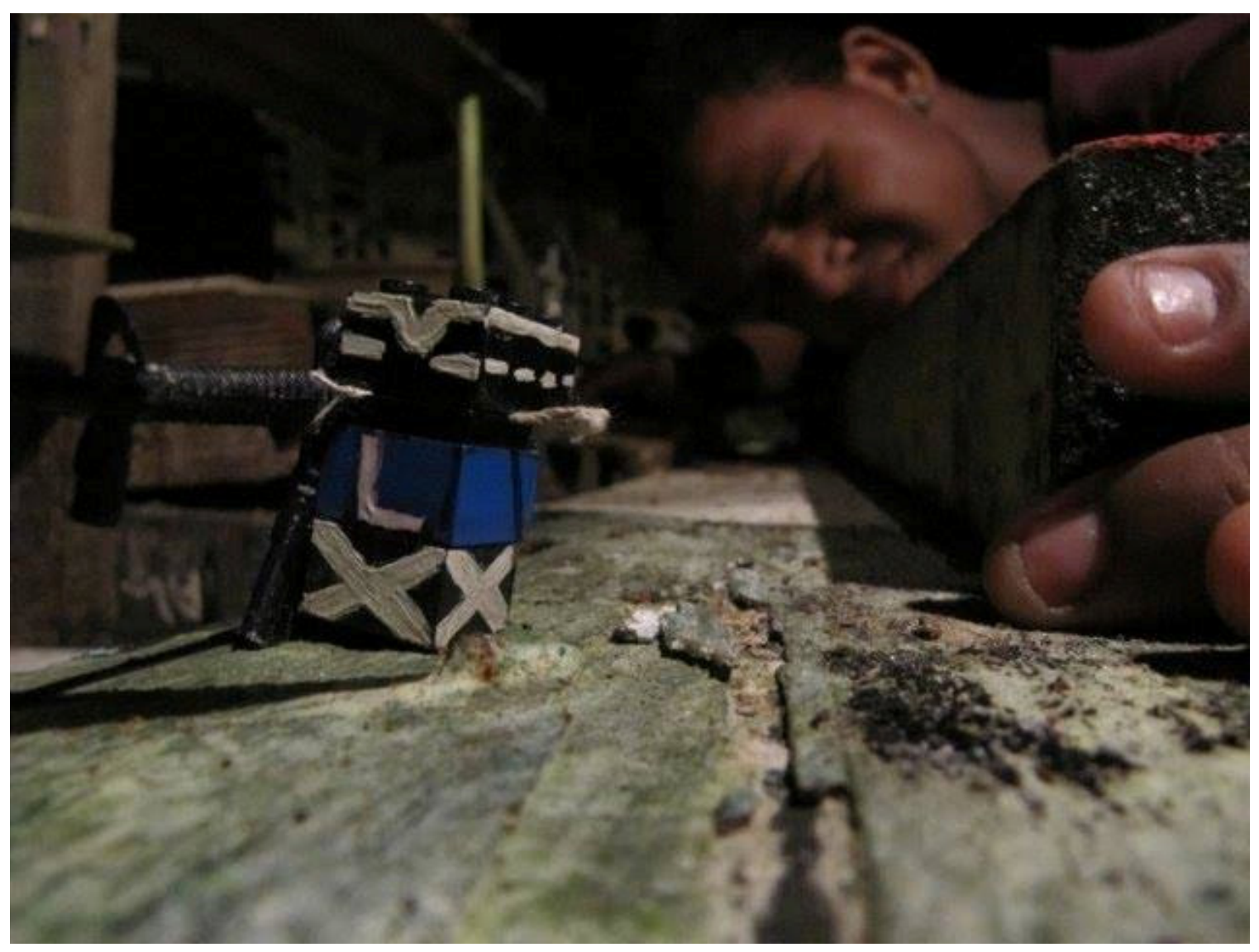


Photo N3

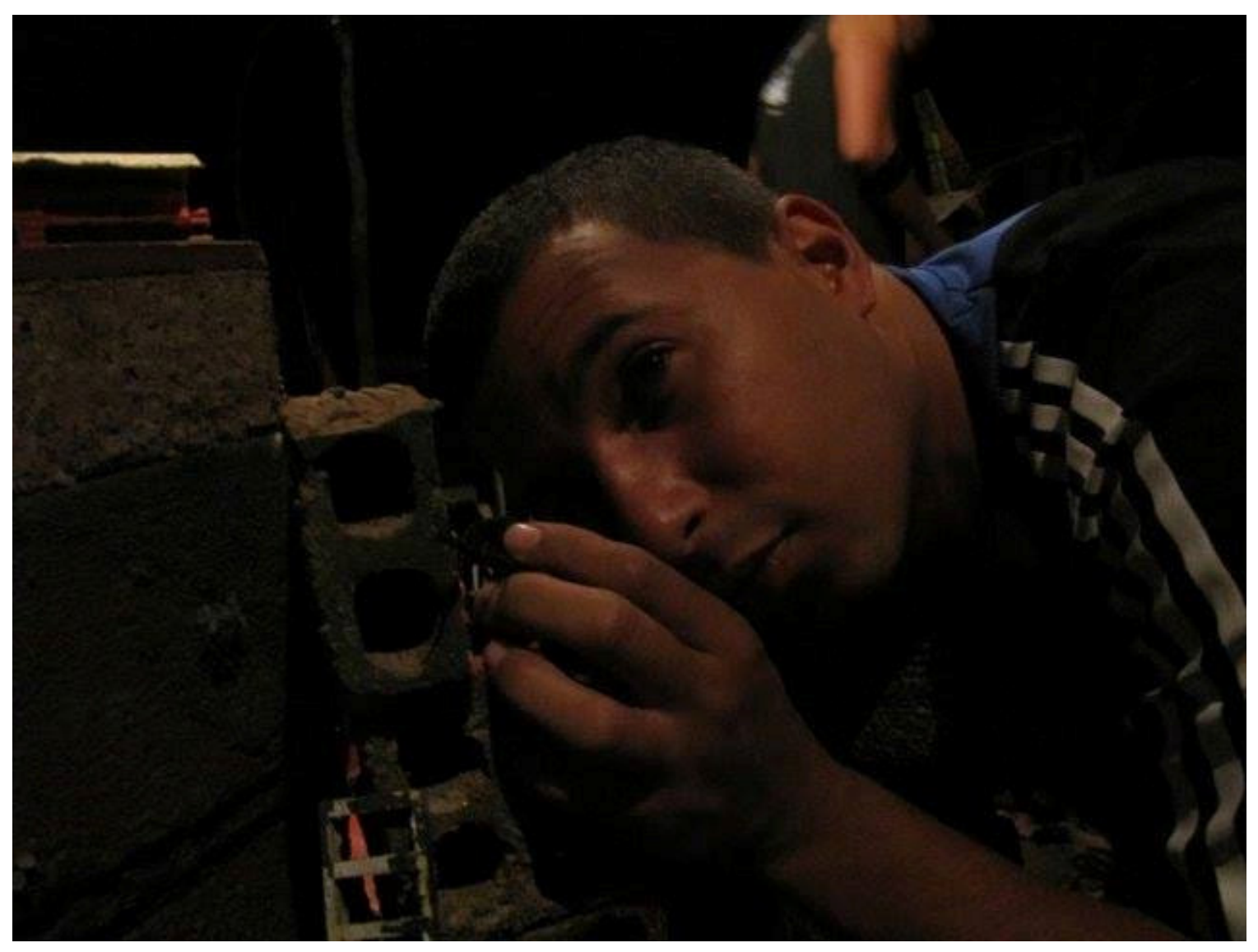


Photo N4

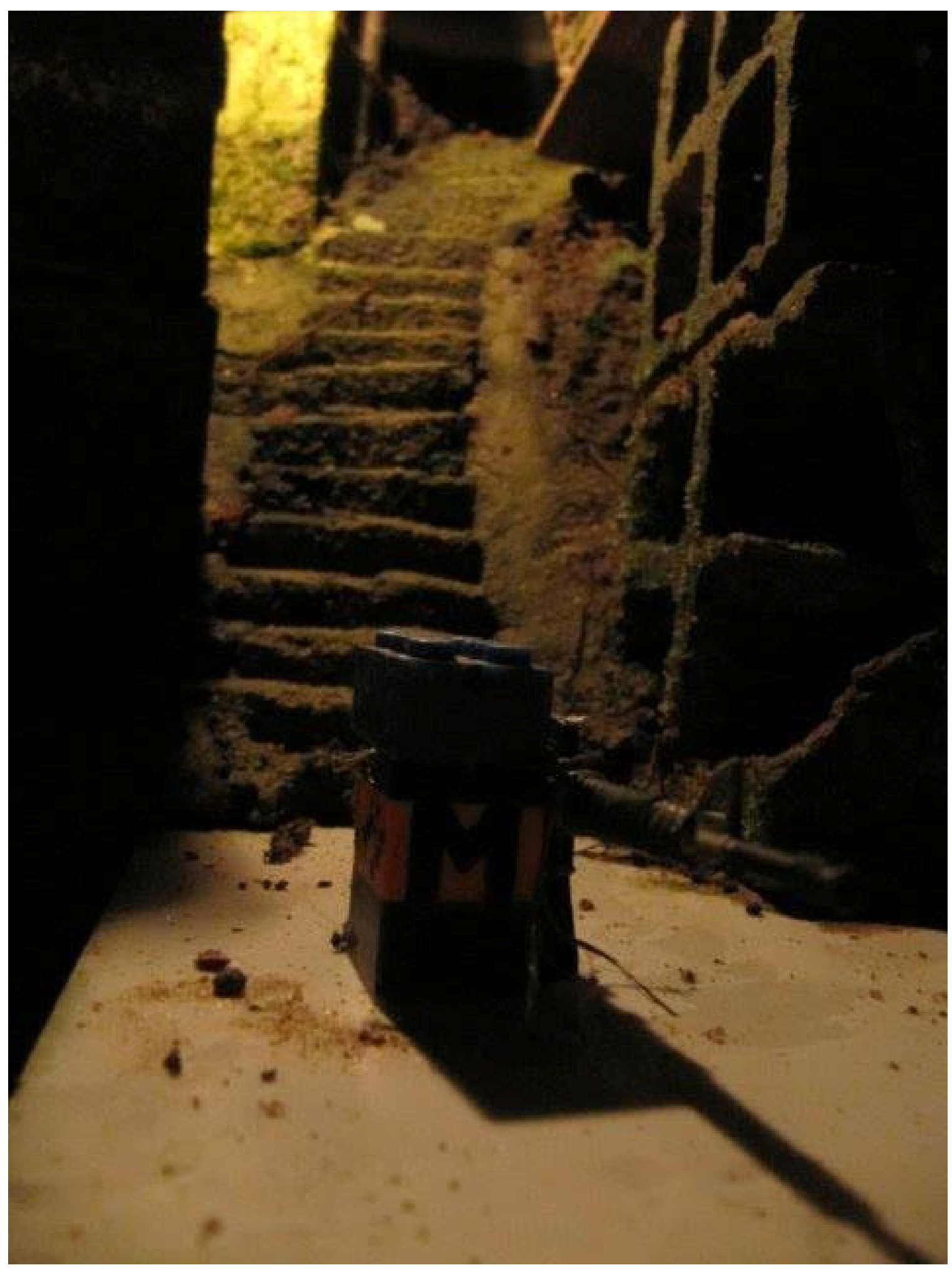


Photo N8

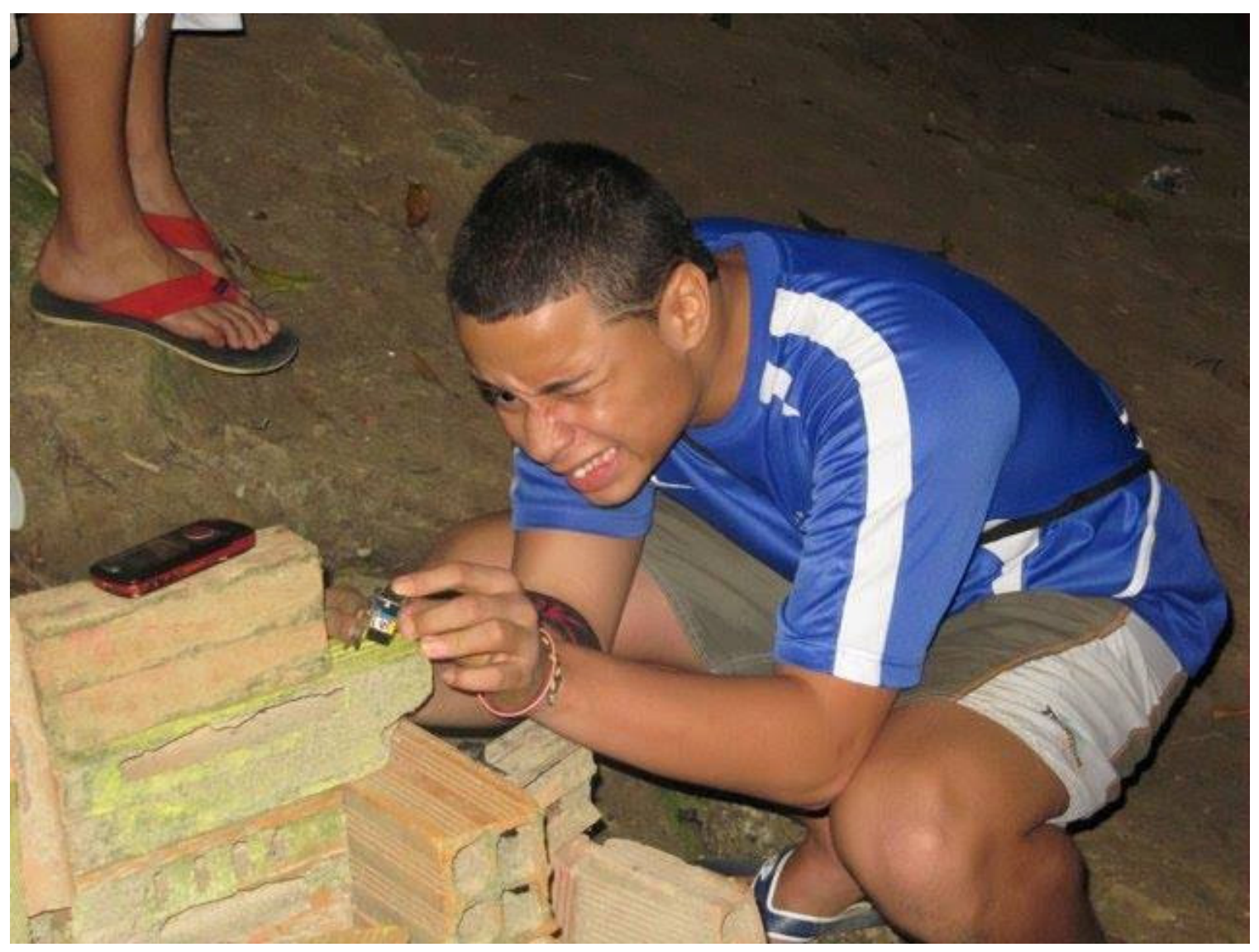


Photo N12

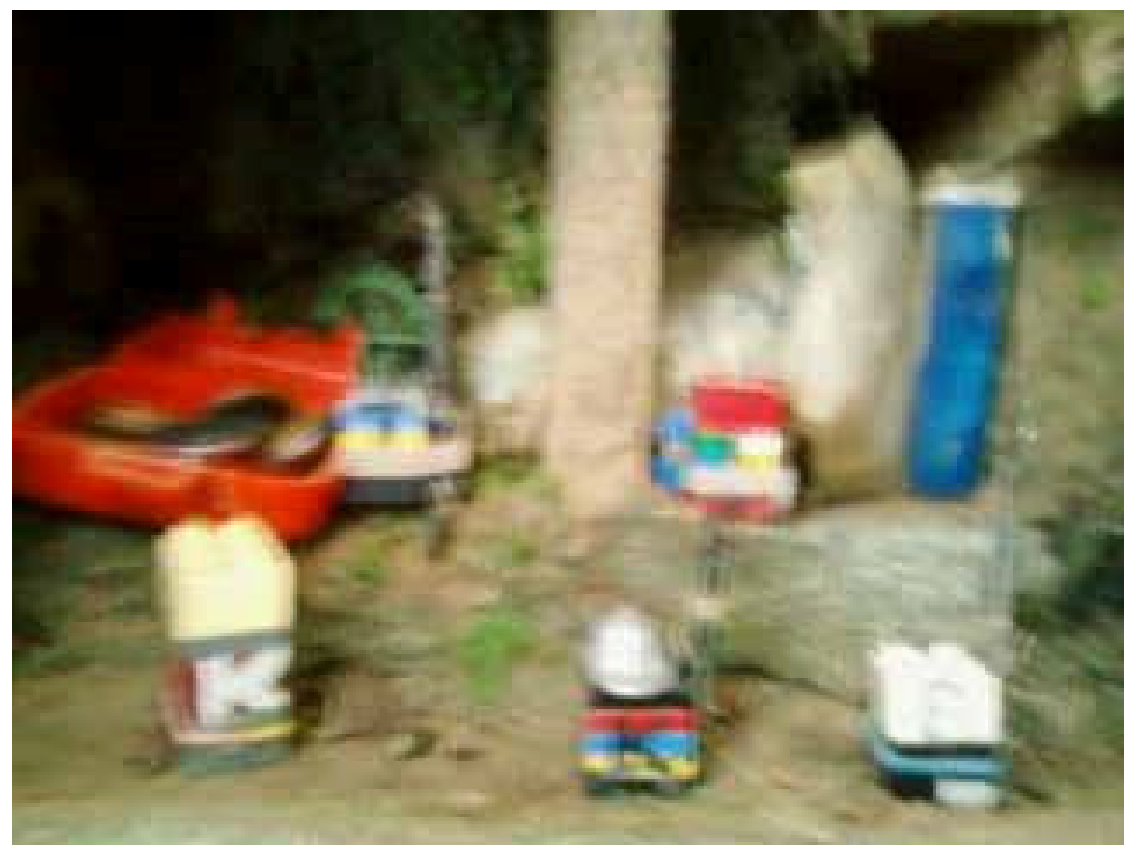


Photo N13

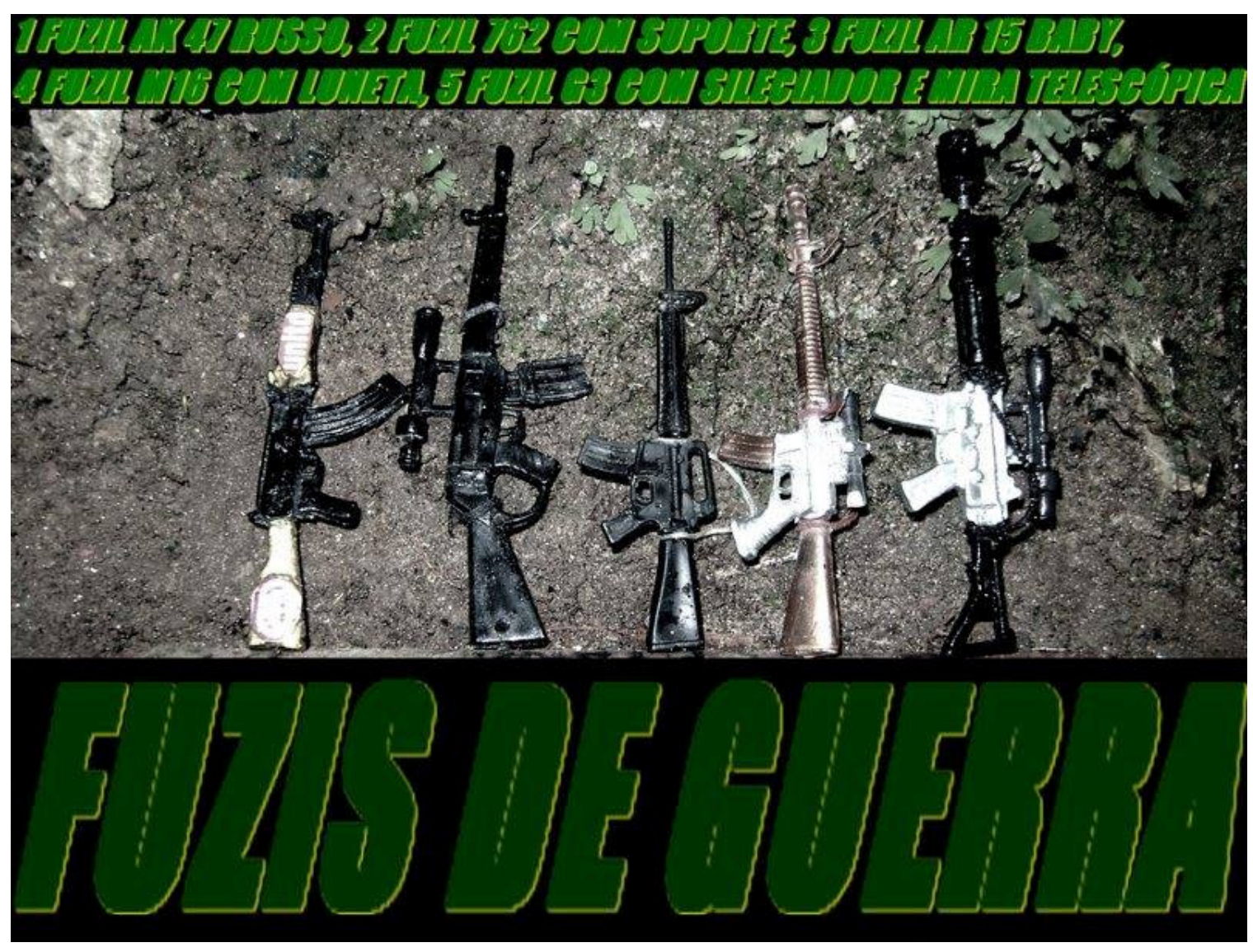


Photo N14

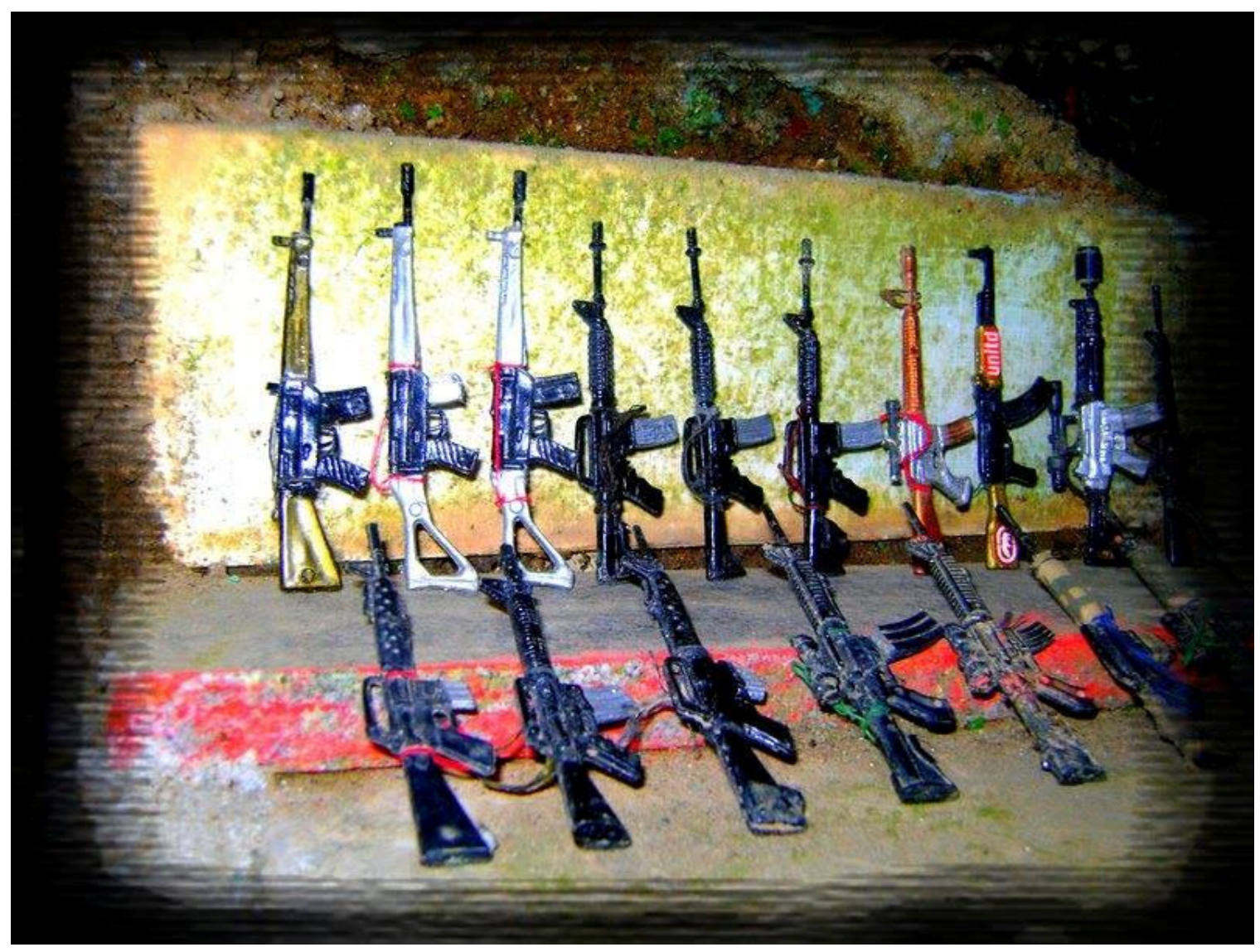


Photo N15

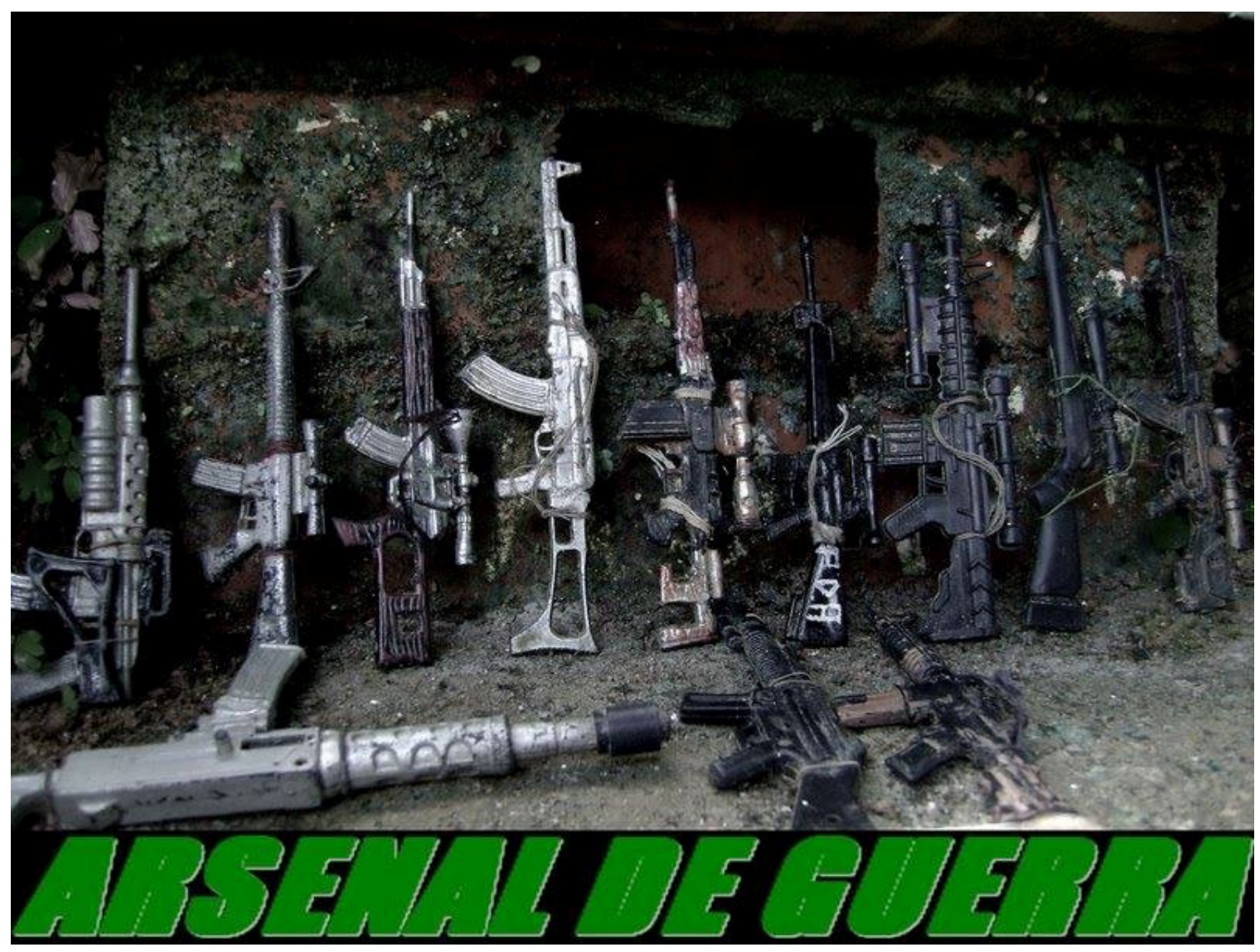




\section{APPENDIX D}

\section{Sample of Analysis Process}

RANI - "While we were traveling, when we traveling and everything, there were others that didn't have this same luck, they abandoned the project and they ended up dying. This could have happened to almost everyone in the project, if the project didn't exist. Because, when you live in a comunidade, in a favela, there is no incentive, you end up on the 'wrong side', the 'wrong path. The 'wrong side' is the trafficking, of drugs. Many became addicted to drugs, and a lot ended up becoming traffickers themselves.... They die, either the police kills them or other drug traffickers will kill them when they mess up." 175

\section{Meaning fields}

\{I feel very fortunate to have been able to travel like I have (AND), it was a really great experience (AND), not all of the boys from Pereira da Silva have had the same opportunities that I have (BECAUSE) there were some boys that were a part of Morrinho but they stopped (BECAUSE/AND) they became involved in drug trafficking (AND) they died (AND) this could have happened to anyone (OR) this could have happened to me (AND) I am not any different than any one else from Pereira da Silva (AND) the participants of Morrinho are not any different than anyone else from Pereira da Silva. Morrinho has helped us a lot (AND) Morrinho has provided us with a lot of great opportunities for work and travel (AND) I am very fortunate to be a part of Morrinho (AND) I am very appreciative of what Morrinho has allowed me to do. (BECAUSE) it is difficult being from a favela (AND) there are a lot of negative influences in a favela (AND) there are not many positive outlets of energy for youth in a favela. (AND) if you live in a favela it can be easy to end up working for the traffickers (AND) this is illegal (AND) this is dangerous (AND) you may die a violent death either from the traffickers themselves (OR) the police (AND) you may become addicted to drugs (AND) this is bad for your health (AND) this is bad for your future.

\footnotetext{
175 "Enquanto alguns de nós viajamos e tudo, tiveram outros que não tiveram a mesma sorte, abandonaram o projeto e acabaram morrendo. Isso poderia ter acontecido com quase todo mundo do projeto, se não existisse o projeto, porque, quando você mora na comunidade, na favela, que não tem nada assim de incentivo, você acaba entrando nesse lado errado, no caminho errado. O lado errado é o tráfico, né, as drogas. Muitos viram viciados em drogas, e muitos viram traficantes mesmo.... Ah, morrem, ou a polícia mata, ou os próprios bandidos matam quando eles vacilam."
} 


\begin{tabular}{|c|c|c|c|}
\hline & Objective & Subjective & Normative-Evaluative \\
\hline 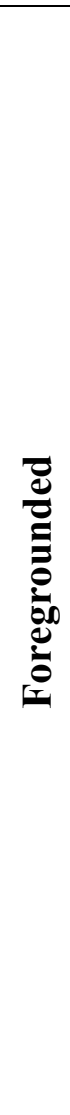 & $\begin{array}{l}\text { I am part of a group of } \\
\text { people that gets to } \\
\text { travel to other } \\
\text { countries. There are } \\
\text { others that live in my } \\
\text { favela who decided to } \\
\text { not be part of our } \\
\text { group. Some of these } \\
\text { people ended up dying } \\
\text { in drug trafficking, } \\
\text { which is what can } \\
\text { happened sometimes. }\end{array}$ & $\begin{array}{l}\text { Morrinho has been a } \\
\text { great experience for me } \\
\text { and the other } \\
\text { participants. The } \\
\text { organization has } \\
\text { allowed us to have so } \\
\text { many wonderful } \\
\text { experiences in other } \\
\text { countries (AND) in } \\
\text { other cities in Brazil. } \\
\text { From these experiences } \\
\text { we have been able to } \\
\text { grow and mature into } \\
\text { healthy adults. There } \\
\text { are some others who } \\
\text { made the decision to } \\
\text { not remain part of } \\
\text { Morrinho and decided } \\
\text { to join the drug } \\
\text { trafficking networks. } \\
\text { (AND) as a result the } \\
\text { ended up dying } \\
\text { violently. }\end{array}$ & $\begin{array}{l}\text { Getting involved in } \\
\text { drug trafficking is } \\
\text { rather common for } \\
\text { where I come from. It } \\
\text { is a bad idea to get } \\
\text { involved in drug } \\
\text { trafficking, but it } \\
\text { happens sometimes. }\end{array}$ \\
\hline 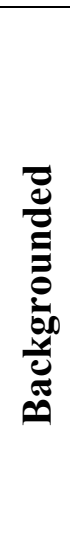 & $\begin{array}{l}\text { The decision that } \\
\text { certain boys made had } \\
\text { violent impacts on } \\
\text { them and their futures. }\end{array}$ & $\begin{array}{l}\text { The boys who decided } \\
\text { to not participate with } \\
\text { Morrinho made bad } \\
\text { decisions that } \\
\text { ultimately ended their } \\
\text { lives. But I do not } \\
\text { think I or anyone in my } \\
\text { group is any better than } \\
\text { them. We are all very } \\
\text { similar, we just made } \\
\text { different decisions. }\end{array}$ & $\begin{array}{l}\text { Youth development } \\
\text { organizations like } \\
\text { Morrinho can be very } \\
\text { influential in the lives } \\
\text { of the youth from } \\
\text { favelas. These youth } \\
\text { need more support in } \\
\text { order to become } \\
\text { successful adults. }\end{array}$ \\
\hline
\end{tabular}




\begin{tabular}{|l|l|l|l|}
\hline & $\begin{array}{l}\text { The youth from Pereira } \\
\text { da Silva make different } \\
\text { decisions that will } \\
\text { greatly impact their } \\
\text { lives. But we all come } \\
\text { from the same place. } \\
\text { The difference is that } \\
\text { youth from Pereira da } \\
\text { Silva could have } \\
\text { participated with } \\
\text { Morrinho. If the } \\
\text { project were more } \\
\text { expansive, it could } \\
\text { positively affect the } \\
\text { lives of more youth. }\end{array}$ & $\begin{array}{l}\text { The situation in Rio de } \\
\text { Janeiro is such that } \\
\text { many valuable lives are } \\
\text { being lost at a young } \\
\text { age due to criminal } \\
\text { networks. If there were } \\
\text { more youth } \\
\text { organizations, there } \\
\text { would be the possibility } \\
\text { for more healthy and } \\
\text { productive members of } \\
\text { society. }\end{array}$ \\
\end{tabular}

\section{Reconstructive Horizon Analysis}

"While we were traveling, when we traveling and everything, there were others that didn't have this same luck, they abandoned the project and they ended up dying. This could have happened to almost everyone in the project, if the project didn't exist." 


\section{APPENDIX E \\ Sample Email For Member Checking In English}

Hello All!

I've analyzed the information from your interviews and I've generalized some conclusions. Could you read what I've written below and tell me if you agree or not? Is there anything that I should change or emphasize?

I would really like to know what you think!

Description of Morrinho

1. It is the best game, where you spent hour and hours of your childhood and could still pass if you had the time. I was a refuge from the violence in the favela at the time when it started.

2. It was and is a great opportunity to work and travel.

3. It is a social project by providing a place for children to spend time learning something.

Morrinho communicates to those who see the model and the films

4. It has a bit of everything that exists in favelas. There is trafficking and violence, but there are also people who work and have families.

5. It shows the side of trafficking and violence. Even though the situation is changing, this still exists in the favelas.

6. It shows the day to day of a resident with his or her family, the dances, and also the shooting.

Morrinho as an organization

7. It is an alternative version of what the media says about the favelas.

8. It is necessary to integrate the favelas more into society and support them as a part of the city.

9. It is an example of something good that exists in the favelas.

How Morrinho helped the youth of Pereira da Silva

10. It showed that you all are artists. It transformed you into artists.

11. It increased your value as a person. It increased your level of pride.

12. It taught you about other culture, whether it be about the asfalto of Rio de Janeiro, or about living in another country, or about the culture of other countries due to the tourism and volunteers at Morrinho.

13. It provided you with a positive role-modeling and helped you to make good decisions.

What it is like living in Pereira da Silva

14. There are some problems, but it's basically a good place to live.

15. The government creates problems for the favelas. 
16. The favelas are socially excluded.

17. The situation is improving for the favelas, though there still exist some problems.

The terminology of favela, morro, and comunidade

18. Favela is a pejorative term.

19. Morro is when people live on a hill, where the land is inclined.

20. Some think that the term comunidade is more socially accepted and it a nicer term. But some think that using the term comunidade implies prejudice and discrimination.

21. Basically the three terms are all equal.

Description of Pereira da Silva

22. It is a quiet and peaceful place to live.

23. There is a sense of community in Pereira da Silva. People help each other.

24. Pereira da Silva is centrally located and is close to everything.

25. It used to be very violent in Pereira da Silva. Residents of other favelas still live in fear of shooting.

26. There is an increased level of poverty in favelas, and there is a lack of public services. Though, some people live well and many have financial resources.

Discrimination for living in a favela

27. People from outside of the favela (the asfalto) think they are traffickers or criminals. Because of this, the police are more abusive if they see you coming from the favela.

28. There exist discrimination based on stigma that favela resident are impoverished, but this isn't always true.

29. There is discrimination in the employment sector. If you are interviewing for a job on the asfalto, and the find out that you live in a favela, they are likely to not offer you the job.

30. There is more discrimination against Black and people with darker skin than against Whites or people with lighter skin.

31. There are ways to avoid prejudice by the way of dressing, talking, walking, and behaving.

Experiences in school

32. It was a good experience, the teachers were good (even if some were absent a lot). You learned a lot and make a lot of friends.

33. You didn't like school because you didn't like being in a classroom all day. Some teachers would nag, and you found this annoying.

34. It was difficult to graduate. 


\section{Sample Email For Member Checking In Portuguese}

\section{Olá Geral!}

Analisei a informação de suas entrevistas e generalizei algumas conclusões. Poderiam ler o quê escrevi embaixo e me dizer se estão de acordo ou não? Têm algo que devo mudar ou enfatizar?

Gostaria muito saber o quê pensam!

Descrição de Morrinho

1. É a melhor brincadeira onde se passava horas e horas de criança e ainda poderia passar se tivesse o tempo. Foi um refugio da violência da comunidade na época quando começou.

2. Foi e é uma excelente oportunidade de trabalho e viajar.

3. É um projeto social de como forneceu um lugar pra crianças para passar o tempo a aprender algo.

O quê Morrinho comunica aos que vêm a maquete e os filmes

4. Têm de tudo nas comunidades. Existe o tráfico e a violência, mas também existem pessoas que trabalham e têm suas famílias.

5. Mostra mais o lado do tráfico e a violência. Mesmo que a situação esteja mudando, isto ainda existe nas comunidades.

6. Mostra o dia ao dia de um morador com sua família, os bailes, e também o tiroteio.

O quê Morrinho comunica da sociedade

7. É uma versão alternativa do que a mídia diz dos morros.

8. É preciso integrar mais as comunidades na sociedade e apoiar como parte da cidade.

9. É um exemplo de algo positivo que existe nos morros.

Como Morrinho ajudou aos jovens de Pereira da Silva

10. Mostrou que são artistas. Transformou em artistas.

11. Aumentou seu valor como pessoa. Criou mais orgulho em se mesmo.

12. Ensinou de outras culturas, seja como é no asfalto no Rio de Janeiro, ou como é morar em outro país, ou um pouco da cultura da outros países por causa dos turistas e os voluntários.

13. Forneceu com um exemplo positivo de vida. Ajudou fazer boas decisões.

Como é morar em Pereira da Silva?

14. Têm alguns problemas, mas basicamente é bom lugar para viver.

15. O governo cria problemas para as comunidades.

16. Os morros estão excluídas socialmente.

17. A situação dos morros está melhorando, a pesar de algumas coisas. 
Terminologia de favela, morro, e comunidade?

18. Favela é um termo pejorativo.

19. Morro é quando pessoas moram num morro, onde a terra é inclinada.

20. Alguns pensam que o termo comunidade é mais aceitado socialmente, mais bonito. Mas alguns pensam que usar o termo "comunidade" leva mais prejuízo.

21. Basicamente os três termos são todos iguais.

Descrição de Pereira da Silva

22. É uma lugar tranquilo e calmo pra morar.

23. Existe um sentimento de comunidade em Pereira da Silva, se ajuda um ao outro.

24. Pereira da Silva está muito bem situado na cidade, é perto de tudo.

25. Antes foi muito violento morar em Pereira da Silva. Moradores de outras comunidades ainda vivem com medo de tiroteio.

26. Existe mais pobreza nas comunidades, e têm mais falta de serviços públicos. Mesmo assim algumas pessoas moram muito bem e têm muitos recursos financiais.

Prejuízo por morar numa comunidade

27. Pessoas de fora da comunidade (o asfalto) pensam que são traficantes ou criminais. Por causa disso a policia abusa mais se te vê baixando do morro.

28. Têm prejuízo por cause de pessoas pensarem que os moradores não têm recursos financiais. Mas não é sempre a verdade.

29. Existe prejuízo no trabalho. Se está entrevistando por um trabalho de carta assinada no asfalto, e se saberem que mora no morro, podem não oferece-te o trabalho.

30. Existe mais prejuízo contra negros e pretos que contra pessoas com a pele mais clara.

31. Têm maneiras de evitar a prejuízo com a maneira de vestir, falar, caminhar, se comportar.

As experiências na escola

32. Foi uma boa experiência, os professores eram bons (mesmo que alguns faltavam muito). Aprenderam muito, e teve os amigos.

33. Não gostou muito da escola porque não gostou de estar na aula todo o dia. Alguns professores ficavam muito em seu pê, incomodar muito.

34. Foi muito difícil se formar. 
VITA

BRYN E. HAFEMEISTER

\begin{tabular}{|c|c|}
\hline 1995-1999 & $\begin{array}{l}\text { B.B.A., Marketing } \\
\text { Texas Tech University } \\
\text { Lubbock, Texas }\end{array}$ \\
\hline $2003-2005$ & $\begin{array}{l}\text { M.A., Latin American Studies } \\
\text { University of Miami } \\
\text { Coral Gables, Florida }\end{array}$ \\
\hline 1999-2000 & $\begin{array}{l}\text { Tour Consultant } \\
\text { EF Educational Tours } \\
\text { Dallas, Texas }\end{array}$ \\
\hline $2000-2001$ & $\begin{array}{l}\text { English as a Second Language Teacher } \\
\text { The British School } \\
\text { Rome, Italy }\end{array}$ \\
\hline $2001-2003$ & $\begin{array}{l}\text { Spanish Teacher } \\
\text { Rockwall High School } \\
\text { Rockwall, Texas }\end{array}$ \\
\hline $2003-2005$ & $\begin{array}{l}\text { Research Assistant, Department of Anthropology } \\
\text { University of Miami } \\
\text { Coral Gables, Florida }\end{array}$ \\
\hline $2005-2006$ & $\begin{array}{l}\text { Program Coordinator, Center for Hemispheric Policy } \\
\text { University of Miami } \\
\text { Coral Gables, Florida }\end{array}$ \\
\hline 2006-2008 & $\begin{array}{l}\text { Social Studies Teacher } \\
\text { Miami Springs Senior High School } \\
\text { Miami Springs, Florida }\end{array}$ \\
\hline $2008-2010$ & $\begin{array}{l}\text { Social Studies Teacher } \\
\text { Ronald Reagan-Doral Senior High School } \\
\text { Doral, Florida }\end{array}$ \\
\hline $2009-2013$ & $\begin{array}{l}\text { Co-Founder and President } \\
\text { Morrinho U.S.A. } \\
\text { Miami, Florida }\end{array}$ \\
\hline
\end{tabular}


2010-2012

Graduate Assistant, Department of Teaching and Learning Florida International University

Miami, Florida

2012-Present

Spanish Teacher

Booker T. Washington High School for the

Performing and Visual Arts

Dallas, Texas

\section{PRESENTATIONS AND PUBLICATIONS}

Hafemeister, B. E. (2005). Identity and adaptation of Brazilian immigrants in Miami. (Master's Thesis). Coral Gables, FL: University of Miami.

Hafemeister, B. E. (2011). An analysis of a small favela-based youth organization. In M.S. Plakhotnik, S. M. Nielsen, \& D. M. Pane (Eds.), Proceedings of the Tenth Annual College of Education \& GSN Research Conference (pp. 48-55). Miami, FL: Florida International University. http://coeweb.fiu.edu/research_conference/

Hafemeister, B. E. (2011, May). Liberation through education in the favelas of Rio de Janeiro? Paper presented at the $55^{\text {th }}$ Annual Comparative and International Education Society Conference, Montreal, Canada.

Hafemeister, B. E. (2011, May). An analysis of video production used as pedagogy: Implications for the development of non-formal education for Rio de Janeiro's marginalized youth. Paper presented at the $55^{\text {th }}$ Annual Comparative and International Education Society Conference, Montreal, Canada.

Hafemeister, B. E. (2012, April). A qualitative case study of a youth development organization in Brazil. Paper presented at the $56^{\text {th }}$ Annual Comparative and International Education Society Conference, San Juan, Puerto Rico. 